UNIVERSIDADE DE SÃO PAULO

FACULDADE DE ECONOMIA, ADMINISTRAÇÃO E CONTABILIDADE DEPARTAMENTO DE ADMINISTRAÇÃO PROGRAMA DE PÓS-GRADUAÇÃO EM ADMINISTRAÇÃO

O MANAGEMENT E O ÍNDIO: UM ESTUDO SOBRE O PROGRAMA DE SUSTENTABILIDADE SOCIOAMBIENTAL E CULTURAL NA TERRA INDÍGENA APUCARANINHA, PARANÁ

Adriana Vinholi Rampazo

Orientador: Prof. Dr. Moacir de Miranda Oliveira Junior

SÃo PAULO 
Prof. Dr. Marco Antonio Zago Reitor da Universidade de São Paulo

Prof. Dr. Adalberto Américo Fischmann Diretor da Faculdade de Economia, Administração e Contabilidade

Prof. Dr. Roberto Sbragia

Chefe do Departamento de Administração

Prof. Dr. Moacir de Miranda Oliveira Junior Coordenador do Programa de Pós-Graduação em Administração 


\section{O MANAGEMENT E O ÍNDIO: UM ESTUDO SOBRE O PROGRAMA DE SUSTENTABILIDADE SOCIOAMBIENTAL E CULTURAL NA TERRA INDÍGENA APUCARANiNHA, PARANÁ}

Tese apresentada ao Departamento de Administração da Faculdade de Economia, Administração e Contabilidade da Universidade de São Paulo como requisito parcial para a obtenção do título de Doutora em Ciências.

Orientador: Prof. Dr. Moacir de Miranda Oliveira Junior

Versão Corrigida

(versão original disponível na Faculdade de Economia, Administração e Contabilidade)

\section{SÃO PAULO}


FICHA CATALOGRÁFICA

Elaborada pela Seção de Processamento Técnico do SBD/FEA/USP

\section{Rampazo, Adriana Vinholi}

O management e o índio: um estudo sobre o programa de sustentabilidade socioambiental e cultural na terra indigena Apucaraninha,

Paraná / Adriana Vinholi Rampazo. - São Paulo, 2015.

$189 \mathrm{p}$.

Tese (Doutorado) - Universidade de São Paulo, 2016.

Orientador: Moacir de Miranda Oliveira Júnior.

1. Ideologia 2. Management 3. Indígenas 4. Desenvolvimento 5. Progresso I. Universidade de São Paulo. Faculdade de Economia, Administração e Contabilidade. II. Título.

CDD -301 
Aos meus grandes amores, Pedro e Lauro, por sonharem, junto comigo, um mundo melhor. 


\section{AGRADECIMENTOS}

Nesses quase quatro anos de doutorado eu juro que, muitas vezes, achei que não iria terminálo. Ter que cumprir todos os requisitos durante os créditos e ainda pensar no meu projeto enquanto tinha que me desdobrar entre Londrina, onde moro, São Paulo, sede da USP, e Paranavaí, onde trabalho, foi mesmo uma loucura. Havia dias que eu acordava em São Paulo, almoçava em Londrina e jantava em Paranavaí. Isso que eu ainda tinha, como muitas mulheres brasileiras, de dar conta do marido e do filho.

Pois é, foi difícil, mas eu dei conta. E como é bom dizer: "Ufa, eu consegui!". Mas eu não consegui sozinha, pois muitas pessoas passaram por esta etapa da minha vida dando uma mãozinha. Algumas vezes, me indicando bibliografia, né, Gustavo Matarazzo Resende, meu querido amigo da UFSC; outras, fazendo uma ponte com meu orientador, como o fez a Priscila, sua assessora, tantas vezes. Outras, indo tomar uma cerveja (sem álcool sim!) e jogar conversa ao vento, como fizeram meus amados amigos Isabela Campoi (que ainda me reservou um quartinho no seu AP), Fábio Hanna e Gisele Ratiguieri. Outras, que abriram portas no campo para mim com tanta gentileza, como o Diego Rodrigues. Não posso me esquecer também dos indígenas que me receberam em suas casas com tanto carinho. Além das diversas pessoas que se mostraram solícitas e me receberam para a entrevista por horas. Além do meu orientador, Moacir, que me possibilitou voar, me dando a autonomia necessária para isso, e os membros da banca de qualificação, professores Luiz Alex Saraiva e Célio Bermann, que deram ideias brilhantes para que o projeto fosse factível e me ajudando com bibliografia e discussões empolgantes. Serei eternamente grata a todos.

Por fim, o agradecimento mais especial vai ao meu marido, Lauro, e ao nosso filho, Pedro. Lauro, pelo seu companheirismo e amor, eu só tenho a agradecer. Sem você, isto não existiria. Foi você que tomou conta de tudo sozinho quando eu não estava para te ajudar. Sua fé na minha capacidade, muitas vezes, foi maior do que a minha mesma, me impulsionando. Nas horas de desespero era seu colo, sempre presente, que me acolheu. Obrigada, obrigada, obrigada... Eu poderia encher mil páginas com obrigada, mas tenho consciência de que não seria suficiente.

E você, Pedro, meu lindo "blonde power" de olhos azuis, que atuou como crítico em diversos momentos lendo os meus textos. Seu equilíbrio teórico - somos a prova de que um filho pode ser muito mais equilibrado do que seus pais - sempre me surpreende. Você não sabe o quanto os debates que tínhamos em casa sobre diferentes pensadores, até altas horas, foram importantes, me ajudando a pensar o meu objeto com outros olhares. Danke schön! 
"A gente quer ter voz ativa No nosso destino mandar Mas eis que chega a roda-viva E carrega o destino pra lá." 


\section{LISTA DE ABREVIATURAS E SIGLAS}

AD Análise do Discurso

ANEEL Agência Nacional de Energia Elétrica

COPEL Companhia Paranaense de Energia

CTNP Companhia de Terras Norte do Paraná

FUNAI Fundação Nacional do Índio

INEP Instituto Nacional de Estudos e Pesquisas Educacionais Anísio Teixeira

MPF Ministério Público Federal

OI Organização Indígena

PBA Projeto Básico Ambiental

$\mathrm{PCH} \quad$ Pequena Central Hidrelétrica

PPTAL Projeto Integrado de Proteção às Populações e Terras Indígenas da Amazônia Legal

PROCERA Programa de Crédito Especial para Reforma Agrária

PWA Programa Waimiri-Atroari

SPI Serviço de Proteção aos Índios

SPILTN Serviço de Proteção aos Índios e Localização de Trabalhadores Nacionais

TAC Termo de Ajustamento de Conduta

TR Termo de Referência 


\section{RESUMO}

O Programa de Desenvolvimento Sustentável Socioambiental e Cultural da Terra Indígena Apucaraninha foi criado como condicionalidade para que a comunidade pudesse receber parte dos recursos oriundos da compensação pela construção e operação da Usina Hidrelétrica de Apucaraninha, instalada dentro das terras indígenas. Teoricamente criado para ser um programa em que os índios participassem de forma ativa e igualitária na sua construção e implementação, já nasce contraditório frente à hegemonia da ideologia da sociedade envolvente imersa na ideologia do management. É assim que tenho como objetivo compreender como o management, enquanto ideologia que se materializa em discurso, atua sobre o Programa de Sustentabilidade Socioambiental e Cultural na Terra Indígena Apucaraninha, Paraná. Para isso, faço uma pesquisa qualitativa em que os discursos, coletados por meio de entrevistas semiestruturadas e grupo focal, aplicados aos indígenas e aos não-indígenas participantes do programa, foram interpretados sob a perspectiva dos elementos da Análise do Discurso na Linha Francesa. Como apoio, ainda analisei documentos do programa e os emitidos pelo Ministério Público Federal. Os principais resultados mostram que, como eu já desconfiava, o programa exclui a participação dos indígenas de fato, uma vez que eles são considerados pelos "brancos", de maneira estereotipada, como irracionais, indolentes e atrasados e, assim, incapazes de escolher o "melhor caminho" para a sustentabilidade do programa que, neste momento, passa se orientar por uma visão economicista e materialista, contrário a lógica dos índios Kaingang. Ao discurso do management, sustentado pelo discurso capitalista, que promete a felicidade, se junta o discurso do colonizador, que trabalha desclassificando o modo de vida dos indígenas, os colocando em uma situação de vulnerabilidade que pode, assim, promover o seu extermínio, mesmo que não seja físico.

Palavras-chave: Ideologia, Management, Indígenas, Desenvolvimento, Progresso. 


\begin{abstract}
The Environmental and Cultural Sustainable Development Program of the Indigenous Land Apucaraninha was set as conditionality for the community be able to receive part of the proceeds from the compensation for the construction and operation of hydroelectric power plant Apucaraninha, located on the indigenous lands. Theoretically designed to be a program in which the Indians where to participate actively and equally in its construction and implementation, is begins contradictory against the hegemony of the ideology of the surrounding society immersed in the management ideology. That's how I aim to understand how the management, as an ideology that is embodied in discourse, acts on the Environmental and Cultural Sustainability Program in the Indigenous Land Apucaraninha, Paraná. Therefore, I make a qualitative research in the discourses, collected through semi-structured interviews and focus groups applied to indigenous and non-indigenous participants in the program, were interpreted from the perspective of the elements of Discourse Analysis on the French Line. As support, it was also analysed program documents and those issued by federal prosecutors. The main results show that, as I suspected, the program excludes the participation of the fact that indigenous people, since they are considered by the "white" of stereotypical way, as irrational, lazy and backward and thus unable to choose "best way" for program sustainability at the moment passes be guided by an economistic and materialistic view, contrary to the logic of the Kaingang. The discourse of management, supported by capitalist discourse, which promises happiness, joins the discourse of colonizer, working disqualifying the way of life of indigenous people, putting them in a vulnerable situation which can thus promote their extermination even than physical.
\end{abstract}

Keywords: Ideology, Management, Indigenous, Development, Progress. 


\section{SUMÁRIO}

1 INTRODUÇÃO

2 PERCURSO METODOLÓGICO $\quad 18$

2.1 Esclarecendo a posição epistemológica $\quad 18$

2.2 A escolha do objeto de pesquisa $\quad 30$

2.3 A pesquisa de campo $\quad 34$

$\begin{array}{ll}2.4 \text { Proposta de análise } & \mathbf{4 0}\end{array}$

3 MANAGEMENT E O PROJETO DE CONTROLE DO MUNDO 47

3.1 O projeto orquestrado: hegemonia e generalização do management 47

4 O "BRANCO" CHEGOU... E A VIDA MUDOU

4.1 Povo Kaingang: uma história de dominação e resistência 68

5 PROGRAMA DE ÍNDIO OU PROGRAMA DE "BRANCO”? 83

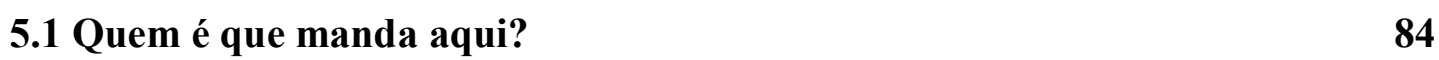

6 MUNDO À PARTE: O OLHAR HOMOGENEIZADOR DOS "BRANCOS" 120 SOBRE OS ÍNDIOS

$\begin{array}{lc}\text { 6.1 Imagem do índio: estereótipos } & 120\end{array}$

7 O ÍNDIO ADMINISTRADO 145

7.1 O "branco" que não venha falar que o índio é diferente 145

$\begin{array}{ll}7.2 \text { Índio capitalista } & 151\end{array}$

REFLEXÕES FINAIS

REFERÊNCIAS

$\begin{array}{ll}\text { APÊNDICES } & 188\end{array}$

Apêndice A - Roteiro semiestruturado de entrevista (indígenas) $\quad 188$

Apêndice B - Roteiro semiestruturado de entrevista (demais 189 entrevistados) 


\section{INTRODUÇÃO}

O clima era de missão. Pesquisadores das duas maiores universidades do Paraná com seus orientandos se encontram em dos melhores hotéis de Londrina para aprender com renomados antropólogos algo sobre a história e os costumes dos índios Kaingang. Neste encontro de um dia, organizado pela COPEL e pelo Ministério Público Federal como parte da preparação dos consultores que iriam atuar no Programa de Desenvolvimento Sustentável Sociocultural, Econômico e Ambiental da Terra Indígena Apucaraninha, não-indígenas, das mais diversas área de conhecimento, se reuniram para tentar compreender quem são os kaingang, os primeiros habitantes daquelas terras, que hoje vivem em um espaço demarcado de pouco menos de seis mil hectares a cerca de 60 quilômetros de Londrina.

O tema era instigante para a maior parte deles, já que se tratava de um público que eles nunca tinham trabalhado. Aquilo tudo era muito novo. Alguns deles tinham tomado consciência de que existia uma comunidade indígena por perto só quando foram chamados a participar do programa. Como pesquisadores, ficaram encantados com o desafio e, mais ainda, com a possibilidade do conhecimento que iria ser gerado para seu próprio trabalho acadêmico, como me contaram alguns dos entrevistados para este estudo.

Neste dia, eu estava entre eles. E pude sentir parte daquilo que acreditavam ser uma honrosa missão: a de salvar os índios da sua situação de miséria e, assim, do seu extermínio. Como os evangelizadores que ainda hoje circulam por comunidades indígenas espalhando a "boa fé" com a missão de salvar suas almas, nós, acreditando na superioridade da nossa forma de vida frente aos “atrasados” índios, assumimos a missão de levá-los ao progresso.

"Os índios pedem socorro", interpretavam os participantes deste encontro após os poucos minutos que foram dados para que as lideranças indígenas que lá estavam pudessem se pronunciar. Durante o almoço, lembro-me que as discussões nas mesas se davam entre esta missão de salvá-los e os palpites para o jogo que mais tarde iria paralisar o encontro, Brasil e Holanda para as quartas de final da Copa do Mundo de futebol de 2010.

Este foi o único momento em que participei daquela "missão", uma vez que tive que me afastar do programa alguns dias depois. Na verdade, só fui conversar com alguém sobre o 
programa cinco anos mais tarde, quando ele se tornou meu objeto de estudo, substituindo o anterior, a Usina de Belo Monte, no Pará. Tudo começou quando eu estava buscado outro local para fazer a minha pesquisa, como tinha sido aconselhada por um dos integrantes da banca de qualificação, a fazer o estudo mais perto de casa devido o tempo necessário para a coleta dos dados. Para ele, a distância do meu local de moradia - Londrina fica a quase 3.000 quilômetros de Altamira (PA) - e o tempo necessário para a coleta dos dados poderia inviabilizar minha pesquisa.

Com isso na cabeça, comecei a pensar em alternativas mais próximas quando me deparei com uma antiga matéria publicada no jornal local na página da Universidade Estadual de Londrina sobre um evento promovido em parte com o dinheiro da indenização na Terra Indígena Apucaraninha (LEÃO, 2013). O título da matéria, "Povo Kaingang: indenização ajuda a resgatar tradições", me chamou a atenção e me fez lembrar que a poucos quilômetros de Londrina havia uma usina hidrelétrica funcionando em uma comunidade indígena, pela qual os Kaingang de Apucaraninha, nome da Terra Indígena, tinham recebido indenização.

Pronto, eu tinha encontrado uma comunidade que tinha recebido indenização pelos impactos gerados por uma usina hidrelétrica. Resolvi, então, fazer o mesmo estudo que iria fazer em Belo Monte em Apucaraninha. Só que as coisas não foram tão simples assim: a usina de Belo Monte estava em construção; a de Apucaraninha tinha sido construída há mais de 60 anos e, portanto, não havia ninguém na comunidade que iria se lembrar de como era a vida antes da usina, o que tornava impossível a compreensão sobre o conflito entre a lógica do management - e sua noção de progresso - e o espaço vivido no processo de apropriação do território para a sua construção.

Além do mais, percebi logo nos primeiros contatos que a usina não tinha nenhum significado para os índios, de tão acostumados que estavam com a sua presença. Eles não tinham nenhuma noção, portanto, de como a vida era sem a usina. Em contrapartida, eles falavam (ou se queixavam) constantemente do Programa de Desenvolvimento Sustentável Sociocultural, Econômico e Ambiental da Terra Indígena Apucaraninha, que foi criado como condicionante para que a comunidade recebesse os valores de uma indenização paga pela COPEL pela construção e operação da usina. Para muitos, eles tinham sido enganados e a indenização não estava dando retorno para a comunidade, pelo contrário: criava mais conflitos, resultando na cisão da aldeia. 
Apesar de ter se passado tanto tempo, e custado tanto, grande parte do trabalho dos consultores jazia em uma gaveta. Alguns programas, como o de frango caipira, por exemplo, não tinham dado certo. Foram abertos mais de 100 alqueires de áreas para agricultura e não se plantam 10 alqueires. As diárias que eram pagas a muitos indíos para serviços internos tinham escasseado. As roças coletivas eram tão pequenas que não mantinham nem uma família. Enfim, o programa tinha se transformado em vários "projetinhos", como os chamavam os índios, que não garantiam o sustento da comunidade e, pior, era capturado por poucas famílias. A insatisfação deles era tão evidente que várias vezes fui indagada se havia a possibilidade de rever o acordo com a COPEL.

A primeira pergunta que me fiz foi: mas o que deu errado? Naquele dia, no hotel, eu tinha visto tantas pessoas altamente qualificadas nas suas áreas de conhecimento empolgadas com o programa, considerando-o até como uma missão. Além do mais, a palavra de ordem naquele dia de treinamento era "participação" e "autossustentabilidade". É assim que percebi que meu estudo tinha tomado vida e estava caminhando por uma nova estrada, tendo o programa de desenvolvimento papel central.

Nao demorou muito para eu perceber que o problema estava na concepção de mundo e na hegemonia do pensamento do homem "branco". Os "brancos" achavam que a forma como os índios viviam era miserável. Para tirá-los dessa situação, a única saída era impor um modelo de desenvolvimento centrado na produção, no lucro e no mercado. Um modelo utilitarista que vai de encontro com a forma tradicional e a lógica dos indígenas. Aquela missão que eles assumiram no evento em 2010, portanto, só podia ser cumprida quando os índios fossem inseridos ao modo de produção da sociedade envolvente, incutindo a ideologia ${ }^{1}$ do progresso.

A civilização moderna incorporou o mito de progresso evolutivo e racional, justificando o domínio do ser humano sobre todas as outras coisas, inclusive de determinados homens sobre os demais (ADORNO; HORKHEIMER, 1999; MARCUSE, 1973). E este papel não é ncessariamente de homens maus. Muitas vezes, com as melhores das intenções, os "brancos"

\footnotetext{
${ }^{1}$ Levo em conta o que diz Bakhtin (1986, p. 31, grifos do autor) diz sobre a ideologia: "Tudo que é ideológico possui um significado e remete a algo situado fora de si. Em outros termos, tudo que é ideológico é um signo. Sem signos não existe ideologia. [...] No entanto, todo corpo físico pode ser percebido como símbolo [...]. Converte-se, assim, em signo o objeto físico, o qual, sem deixar de fazer parte da realidade material, passa a refletir e a refratar, numa certa medida, uma outra realidade".
} 
agem desta forma acreditando que estão fazendo o melhor para os índios, para que suas vidas mudem, como se esta mudança fosse inexoravelmente positiva.

Assim, impõem a lógica econômica capitalista acreditando que ela poderá resolver todos os problemas dos índios. Como, de uma perspectiva dominante há uma racionalidade superior, a utilitária, as alternativas estão sempre dentro do sistema, como avisa Chanlat (2006). Assim, consultores e demais envolvidos "brancos" do programa se transformam em fonte moral, definindo a forma "correta" pela qual os índios devem pensar e agir para se desenvolver e, assim, alcançar o sucesso e o reconhecimento da sociedade envolvente.

É claro que a comunidade indígena não está em uma bolha, separada da sociedade ao seu redor. Assim, desejam criar gado como seus vizinhos, plantar eucaliptos como apresentado em um programa de TV e adquirir bens de consumo, como telefones celulares, computadores, aparelhos de televisão, tratores e veículos. Até mesmo a alimentação característica dos "brancos" lhes parece mais especial, como arroz, feijão e macarrão. Como qualquer ser humano, não querem ser vistos como inferiores, como diferentes em uma sociedade que apresenta diversas maneiras "adequadas" de viver.

Neste contexto, a reconstrução social se torna inevitável. Nada errado quando os índios modifiquem sua cultura, a partir da interação com o "branco", de forma orquestrada por sua própria lógica. Afinal, mudanças ocorrem conforme o fluxo da história. No entanto, não é isso que está acontecendo, na medida em que a lógica que rege o modo de vida dos índios vem sendo forçosamente modificada por conta do programa de desenvolvimento.

O management, como instrumento do progresso, passa por cima das diferentes formas de vida, tornando os sujeitos meros objetos nas mãos daqueles que vem de fora com um projeto pronto. Impõem seu modelo e modificam os territórios, desestruturando-o e reestruturando-o a partir de novas bases (BERMANN, 2012). É assim que a comunidade passa a ser uma empresa do agronegócio; e os índios, capitalistas. Para existir, o management, orientado por uma visão de progresso iluminista, manipula os valores que são pontos de referência de uma dada comunidade, impondo mudanças.

Como acontece com grande parte dos programas de desenvolvimento em terras indígenas, apesar da retórica da participação, como já apontado por Little (2002), muitas das 
organizações presentes nestes programas não possuem habilidade ou interesse de lidar com o diferente. Assim, apesar de ter sido pensado a partir da ideia de participação dos indígenas no planejamento e gestão do programa, o que se vê é a continuidade da tutela. Os "brancos" participantes do programa já foram a campo com uma imagem pré-concebida dos índios. $\mathrm{O}$ índio imaginário, fruto de um estereótipo construído por séculos, não permitiu que o índio real fosse considerado. Como são vistos como atrasados frente à sociedade envolvente, a relação não se dá entre iguais.

Apesar da boa vontade de alguns, a missão se torna dominação, na medida em que nas teorias do desenvolvimento busca-se a homogeneidade e não a diversidade, estando o conceito carregado da visão particular (PERROT, 2008). Assim, torna-se natural que sejam criados programas de desenvolvimento indígenas visando a intergração dos índios ao modo de vida dos "brancos", na forma de etnofagia, palavra utilizada por Díaz-Polanco (2006) para explicar a domesticação da diversidade étnica pelos parâmetros das sociedades capitalistas. Uma ideia que, apesar de não ser recente, se funda em ideologias que partem da crença de que a forma de vida moderna dos "brancos" é superior e que ser assimilado é entrar na rota para o progresso evolutivo. É assim que os índios são tutelados pelos brancos para que não se percam no caminho.

Assim, ao falar de desenvolvimento, não importando se ele agrega palavras como "sustentável" ou "étnico", sempre estamos nos referindo a uma comparação entre o "bom" e o "mau" desenvolvimento a partir de um modelo cultural, social e econômico ocidental considerado lógico pelo homem europeu, burguês e branco (GONÇALVES, 2002). Não espanta, portanto, que a questão étnica nunca tenha sido devidamente incorporada às teorias do desenvolvimento, conforme Stavenhagen (1984).

Nesta perspectiva, a empresa que possui o poder econômico e simbólico no programa consegue impor sua ideologia de management. A COPEL, proprietária da usina hidrelétrica que opera na terra indígena e que, desde o início, assumiu o papel de gestora do programa, apesar de teoricamente ele ser gerido por um comitê formado por representantes da empresa e dos indígenas, tornou-se a cabeça do programa.

É desta forma que a ideologia do management acabou por orientar a forma como o programa está sendo implantado na comunidade indigena, já que os "brancos" envolvidos, algumas 
vezes sem nem notar, acabam por impor uma única forma de viver. Forma esta alinhada aos imperativos do mercado, a uma visão de que os resultados econômicos são o ponto central de qualquer empreendimento, mesmo que com isso a sociedade tenha que desaparecer (GORZ, 2007).

Ao se pensar diferente corre-se o risco de ser classificado como não racional, o que atrasa o progresso humano, uma vez que a incorporação dessa lógica dominante limita a aceitação de outras racionalidades. Desta forma, o management não se trata apenas de um corpo de técnicas utilizado para gerar resultados, mas também, e principalmente, uma ideologia e, portanto, um mecanismo de poder, afirmam Costa, Barros e Saraiva (2014).

Quando os indígenas venceram a disputa com a COPEL pela indenização e tiveram que aceitar que o pagamento não fosse feito nas suas bases, dividindo o valor entre as famílias, mas da forma em que foi imposta pelos representantes da COPEL e do Ministério Público Federal, por meio de um programa de desenvolvimento, já ficou claro que a forma com que os índios lidam com dinheiro é considerada irracional e, portanto, devem ser controlados pelos "brancos".

Até a empresa que deveria pagar a indenização por anos de exploração nas terras indígenas se torna, então, mais lógica e racional que os índios. Como o discurso dos "brancos" é hegemônico, a "fusão de horizontes", nesta relação interétnica, fica comprometida (MATOS, 2007).

Desta forma, o problema de pesquisa que sustenta esta tese é: de que forma o management, enquanto ideologia que se materializa em discurso, atua sobre o Programa de Sustentabilidade Socioambiental e Cultural na Terra Indígena Apucaraninha, Paraná?

Este problema se materializa no objetivo geral de compreender como o management, enquanto ideologia que se materializa em discurso, atua sobre o Programa de Sustentabilidade Socioambiental e Cultural na Terra Indígena Apucaraninha, Paraná. Para cumprir o objetivo geral, foram definidos os seguintes objetivos específicos:

1) Resgatar o processo histórico de conformação da Terra Indígena Apucaraninha. Este primeiro objetivo se apoia na ideia de que seria ingênuo tentar compreender as relações de 
poder, as ideologias e os discursos que operam mudanças sem compreender o campo. Desta forma, não vejo outra forma de fazer este estudo a não ser me embrenhar na história e resgatar o processo de conformação dinâmico dos Kaingang na Terra Indígena Apucaraninha.

2) Identificar as relações de poder que atuam sobre o programa. Neste objetivo, a ideia é identificar como se dão as relações de poder no programa, uma vez que o seu objetivo principal é a autossustentabilidade econômica dos índios, o que pressupõe, necessariamente, a quebra da tutela a que foram historicamente enquadradados, implantando a gestão participativa. Desta forma, busco identificar as relações de poder e a dominação que resulta dela.

3) Identificar, por meio dos discursos, a imagem que os "brancos" participantes do programa têm dos índios, de maneira a perceber a partir de que imagem opera a forma de relacionamento com os índios.

4) Desvelar os discursos que sustentam a disseminação da ideologia do management entre os participantes do programa.

O discurso do colonizador, presente entre os "brancos", trabalha com o jogo da diferença, sendo inferiores aqueles que são considerados atrasados por não manterem uma lógica igual a sua. Em compensação, o índio mais parecido com o "branco" é descrito de forma mais positiva, como "tranquilo", "carismático", "racional” e "maduro". Para serem reconhecidos como "gente", assim, é preciso se adequar. Com o indigenismo empresarial, as empresas tomam o lugar do Estado no papel de tutor das comunidades indígenas, criando um simulacro do índio que se adequa ao que deseja a empresa (RAMOS, 1995): um índio subserviente, cúmplice e dependente (LUCIANO, 2006). Ao dependerem das empresas, os índios se tornam seus cúmplices, aceitando suas práticas e as defendendo de forma subserviente, abdicando de vez, portanto, da sua autonomia.

A tese que defendo é a de que estes programas de desenvolvimento ditos sustentáveis, supostamente comprometidos com o "progresso capitalista responsável", na verdade ignoram a forma de vida e a racionalidade dos povos indígenas, se transformando em uma nova forma 
de tutela e, portanto, de dominação. Isso ocorre porque tais programas partem de uma lógica hegemônica calcada na ideologia do management que embute um projeto de controle. 


\section{PERCURSO METODOLÓGICO}

Neste capítulo, apresento o percurso metodológico levado a cabo neste estudo. Não apresento apenas procedimentos técnicos, uma vez que a metodologia na pesquisa qualitativa, na qual este estudo se inclui, se deve explicitar o caminho do pensamento do pesquisador, sua visão de mundo e sua práxis para apreensão do fenômeno. Isso é importante, uma vez que o pesquisador é um ser político e, portanto, ideológico, o que faz que o próprio conhecimento também o seja (DEMO, 1995).

Isso não significa que, "ainda que a ideologia seja intrínseca" ao processo de pesquisa, que o resultado não seja científico (DEMO, 1995, p. 20). Científico é aquele estudo que passa pelo critério de discutibilidade, que "marca a substância processual dialética das ciências sociais, além de permitir um tipo mais realista de controle da ideologia quando mantida discutível", defende Demo (1995, p. 27). Assim, desde que a ideologia seja discutível, ou seja, "desde que recorra a argumentos, seja competente em termos formais, a par de disputar posições de poder", avisa Demo (1995, p. 27), ela é científica.

Sendo assim, é preciso deixar claro o "caminho da pesquisa" pelo qual o pesquisador passou, incluindo aí as forças que atuam sobre ele, mesmo este caminho sendo apenas "um enfoque, um ponto de vista, uma interpretação, já que ele próprio não passa de um cientista" (DEMO, 1995, p. 37). Desta forma, começo explicando a minha postura epistemológica pluralista, rejeitando a ideia de incomensurabilidade paradigmática, para, em seguida tratar dos fatores relacionados à escolha do objeto desta pesquisa, o ligando ao lugar que ocupo na sociedade, como pesquisadora e como sujeito, e, assim, como concebo o mundo. Em seguida, contextualizo o problema e defino os objetivos e, por fim, discuto como foi efetuada a coleta e a interpretação dos dados.

\subsection{Esclarecendo a posição epistemológica}

Os pilares do pensamento administrativo foram construídos sob a influência do paradigma positivista (BURREL, 2006). Desde a Escola Clássica, que comporta as ideias de Frederick Taylor e Henry Fayol, passando pela Escola de Relações Humanas, inaugurada pelos experimentos de Elton Mayo na fábrica de componentes eletrônicos da Western Electric em 
Hawthorne, até a disseminação exagerada dos conceitos da Teoria Geral dos Sistemas que tornou a organização um objeto previsível e a prescrição oriunda da Teoria da Contingência, busca-se construir um aporte teórico sobre as organizações que rejeita a divergência e a multiplicidade de paradigmas, isto é, a forma como abordamos nossos objetos de pesquisa ficou por anos restrita a uma só visão.

Como resultado disso, ainda hoje na área da Administração, vivemos um pensamento único, uma ditadura do pensamento, em uma "era de trevas", afirma Saraiva (2014), se inspirando na obra de Sagan. Uma era em que ser crítico ao sistema e conceber a sociedade e as organizações, que não podem ser dela separadas, de uma forma que não seja estritamente econômica e capitalista, é ser estigmatizado com a alcunha de "comunista" e "alternativo".

Este é um quadro de trevas, de uma perigosa escuridão que reserva um lugar periférico a todo aquele que ousa pensar em uma sociedade mais justa e em um conhecimento que sirva a esta sociedade sem necessariamente ser regido por uma lógica economicista (SARAIVA, 2014, p. 5).

A origem do problema talvez esteja mesmo naquelas primeiras décadas da formação da Administração, na necessidade de desenvolver consenso político para o reconhecimento de um campo da ciência, como Burrel (2006) tenta justificar esse fenômeno se apoiando na ideia de Latour (2000) sobre a ciência em construção. Entretanto, não podemos deixar de ver que o resultado disso foi nefasto sobre o conhecimento em Administração, "visto que, quando olhamos para trás, podemos ver não apenas um campo menor, mas um campo onde os poderosos concordaram em ignorar problemas fundamentais no direcionamento de questões fundamentais" (BURREL, 2006, p. 438).

Isso porque, segundo Burrel (2006), ao promoverem o ajustamento das análises organizacionais a um sistema classificatório estático - como em um leito de Procusto $^{2}$ reduziram a dinâmica e aprisionaram o fenômeno em um único paradigma, o da sociologia funcionalista. E, desta forma, disseminou um único ponto de vista, sendo este objetivo, realista, determinista, enfatizando a estabilidade e o consenso. Para Feyerabend (1977, p. 57):

\footnotetext{
${ }^{2}$ Procusto foi, segundo a mitologia grega, um assaltante que capturava as pessoas que passavam em determinada estrada e as obrigava a deitar em uma cama. Caso a pessoa fosse maior que a cama, Procusto cortava seus membros para que se ajustasse a ela; caso fosse menor, ele as esticava.
} 
Unanimidade de opinião pode ser adequada para uma igreja, para as vítimas temerosas ou ambiciosas de algum mito (antigo ou moderno) ou para os fracos e conformados seguidores de algum tirano. A variedade de opiniões é necessária para o conhecimento.

No entanto, o paradigma funcionalista, apesar de mais popular e politicamente superior aos demais no campo da ciência social, não é o único possível para a análise das organizações, uma vez que Burrel e Morgan (2005) concebem quatro paradigmas (figura 1) a partir de pressupostos metateórico básicos que definem o modo pelo qual os cientistas operam. Paradigma, assim, é, nas palavras de Burrel (2006, p. 445):

\footnotetext{
Um senso acordado e profundamente assentado, uma forma de ver o mundo e como este deveria ser estudado, e que este ponto de vista é compartilhado por um grupo de cientistas que vivem em uma comunidade marcada por uma linguagem conceitual comum, e que são possuídos por uma postura política muito defensiva em relação aos de fora.
}

Assim, quando um cientista assume um determinado paradigma, ele deixa de fora os outros, visto que os paradigmas são mutualmente excludentes, pois "suas formas puras são contraditórias, baseando-se em pelo menos um conjunto de suposições metateóricas opostas" sobre a natureza da sociedade - ordem e conflito - e a natureza da ciência - objetiva e subjetiva (BURREL; MORGAN, 2005, p. 25, tradução minha). 


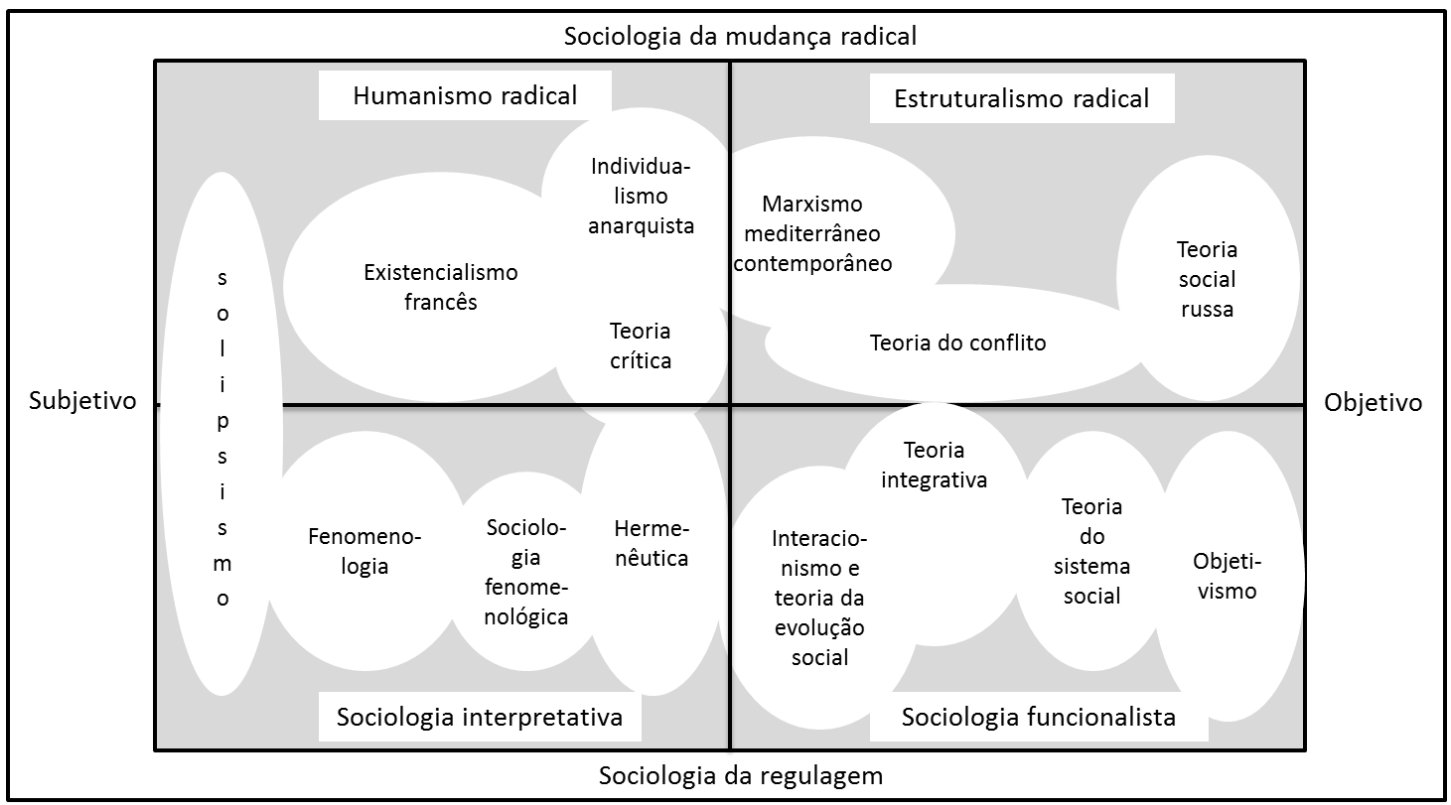

Figura 1 - Os quatro paradigmas sociológicos

Fonte - Burrel e Morgan (2005, p. 29).

Pelo esquema analítico descrito por Burrel e Morgan (2005), os quatro paradigmas em que se encaixam as teorias das organizações se distribuem nas dimensões subjetivas ou objetivas em termos da natureza da ciência: ontologia, epistemologia, natureza humana e metodologia (figura 2).

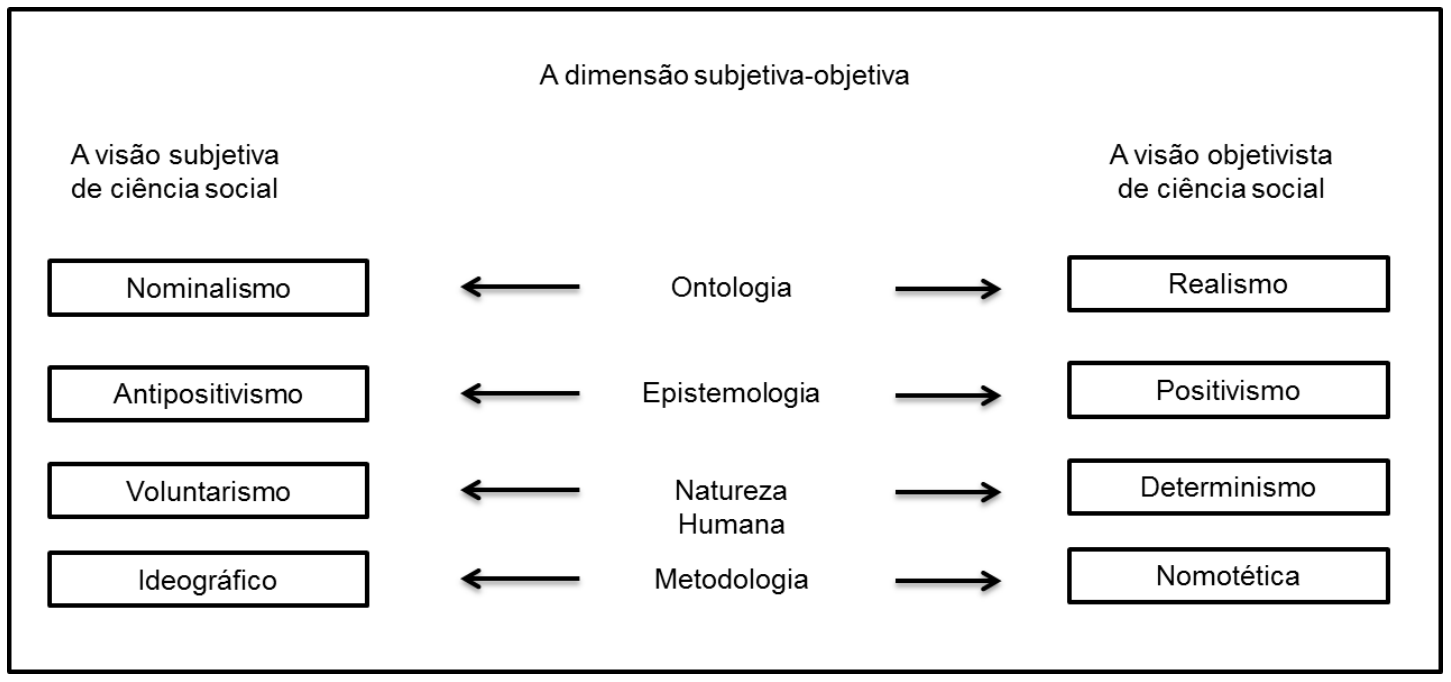

Figura 2 - Esquema de análise das dimensões objetivas e subjetivas

Fonte - Burrel e Morgan (2005, p. 3).

Da mesma forma, os quadrantes superior e inferior, sociologia da mudança radical e sociologia da regulação, se referem à natureza da sociedade, melhor dizendo, refletem as 
diferentes perspectivas da natureza do objeto em estudo com relação à ordem ou ao conflito (BURREL; MORGAN, 2005). Assim, as teorias são distribuídas conforme o ponto de vista que enfatizam seja a ordem, defendendo a estabilidade, a integração, a coordenação funcional e o consenso, ou então, o conflito, onde a mudança, a coerção e a desintegração são o centro.

É desta forma que Burrel e Morgan (2005) defendem que os estudos organizacionais são plurais, como em toda ciência social, e que, apesar da dominação do paradigma funcionalista, existem outras formas de se analisar os fenômenos organizacionais, como o paradigma da sociologia interpretativa, o paradigma do estruturalismo radical e, por fim, o paradigma do humanismo radical. Sendo, que cada um deles definem os fundamentos de formas opostas de se analisar os fenômenos sociais e, assim, implicam, de maneira diferente, o modo como os cientistas das organizações irão desenvolver seus estudos e quais serão seus resultados (BURREL; MORGAN, 2005):

a) Paradigma funcionalista: representa a ideia de ordem, equilíbrio, estabilidade, consenso, integração social e analisa os fenômenos a partir de uma lente objetiva, como convém a tradição positivista que carrega; seus adeptos não desejam mudar a ordem das coisas.

b) Paradigma interpretativo: entende o mundo a partir das experiências subjetivas dos sujeitos e, assim, a realidade é criada mais pelos esquemas subjetivos do que pelos processos externos; como a realidade não existe em qualquer sentido concreto, sendo apenas fruto da experiência subjetiva e objetiva dos sujeitos, não se defendem mudanças.

c) Paradigma Humanista Radical: tem muito em comum com o Paradigma Interpretativo, mas, ao contrário desse, deseja mudar a realidade, vista, em muitos casos, como uma limitação à existência social.

d) Paradigma Estruturalista Radical: defendem a mudança radical de uma perspectiva objetiva a partir da emancipação dos sujeitos da estrutura que os domina.

Assim, o sucesso da obra de Burrel e Morgan (2005) veio justamente por quebrar o "monoteísmo paradigmático" e, assim, abrir possibilidades de outros quadros de referência nos estudos organizacionais para aqueles que não enxergam o mundo somente com a lente funcionalista. Se ainda hoje o funcionalismo é dominante, isso não significa que os teóricos 
das organizações não estejam fazendo seus estudos em paradigmas mais críticos e interpretativos, tornando o "campo vibrante, com visões teóricas distintas que podem enriquecer nossa compreensão da complexidade, da ambigüidade e dos paradoxos organizacionais", lembram Lewis e Grimes (2007, p. 34).

A ideia, no entanto, sofreu várias críticas, principalmente por utilizar uma "abordagem tipicamente funcionalista ao objeto de estudo", enquadrando as diferentes abordagens em quatro paradigmas encaixados em uma matriz, afirma Burrel (2006, p. 446) citando a crítica de Stewart Clegg publicado na Organization Studies em 1982. Mas, a maioria das críticas veio da noção de incompatibilidade de paradigmas que Burrel e Morgan (2005) advogaram durante toda a sua obra. Segundo Burrel (2006, p. 446):

\footnotetext{
Paradigma foi tomado até o momento para sugerir que conceitos e termos e métodos de um paradigma não eram traduzíveis em outros usados por outro paradigma. A ausência de regras de tradução foi presumida por Burrel e Morgan para conduzir à exclusividade mútua de paradigmas. Eles argumentaram que, uma vez que as afirmações metateóricas de paradigmas diferiam, não poderiam existir regras de conversão totalmente efetivas.
}

Nessa visão, há uma incomensurabilidade entre os paradigmas, pois as teorias, as técnicas, os métodos e o próprio significado que os norteiam estão inscritos em linguagens diferentes. $\mathrm{O}$ problema é que Burrel e Morgan (2005) parecem carregar uma das falhas de Kuhn de que a incomensurabilidade se dá devido a problemas de incompatibilidade linguística entre as teorias.

O nosso argumento contra Kuhn pode ser condensado da seguinte forma: uma das características prementes das comunidades científicas é, decerto, a posse de uma linguagem rigorosamente técnica, que pressupõe um aprendizado disciplinado para a sua aquisição, mas isso não quer dizer que as linguagens são intrinsecamente diferentes uma das outras. [...] Portanto, quando a quebra de comunicação eclode, as razões são geralmente de ordem política ou social, e não de natureza lingüística exceto quando há ausência de competência. Com isso, queremos asseverar que a esfera social e política não é externa à própria ciência (MENDONÇA; VIDEIRA, 2007, p. 179). 
As barreiras que impedem as trocas entre paradigmas estão mais nas questões políticas ou sociais do que de linguagem científica per se. Incompatíveis, então, são as pessoas em suas "grades de ferro" e não as teorias e paradigmas. É interessante notar os argumentos dos, chamados por Burrel (2006), "guerreiros do paradigma" para a defesa da incompatibilidade. Para eles, é preciso manter a separação entre paradigmas para se garantir "para os membros internos, pelo menos em curto prazo, a sobrevivência dessa abordagem e, talvez ainda mais importante, a sobrevivência do ponto de vista ideológico do qual ele é feito" (BURREL, 2006, p. 448). Não seria essa uma posição mais política do que científica?

Assim, ao apresentarem os paradigmas em compartimentos hermeticamente fechados, Burrel e Morgan (2005) tiraram a possibilidade de debate e intercâmbio entre as abordagens, afirmam Hassard e Kelemen (2002). Segundo Lewis e Grimes (2007), apesar de Burrel e Morgan (2005) terem legitimados ações em frentes diferentes do paradigma funcionalista em estudos organizacionais, o que é bastante louvável, no entanto, promoveram uma "mentalidade paradigmática" que, ao inibir o diálogo entre os paradigmas, promovem teorias de visões estreitas.

Neste contexto, Gioia e Pitre (1990, p. 585, tradução minha), veem no surgimento de perspectivas multiparadigmáticas uma forma de reduzir essas visões estreitas, uma vez que "o nosso campo não desenvolveu uma abordagem alternativa adequada para a construção de teorias que podem explicar a natureza multifacetada dos fenômenos organizacionais".

Sendo assim, propõem a construção de pontes entre as fronteiras dos paradigmas a partir das suas zonas de transição, visões teóricas que interligam os paradigmas, tendo em vista as dimensões subjetiva, objetiva, da regulagem e da mudança radical, propostas por Burrel e Morgan (2005). As relações entre os paradigmas interpretativo e funcionalista e entre os paradigmas do estruturalismo radical e do humanismo radical podem ser feitas a partir das suas características comuns, respectivamente, da regulagem e da mudança radical e, ao mesmo tempo, em ambos trabalhando dentro de visão ao mesmo tempo objetiva e subjetiva. Da mesma forma, as relações entre o paradigma funcionalista e o do estruturalismo radical e entre os paradigmas do humanismo radical e interpretativo podem se dar a partir, respectivamente, do objetivismo e do subjetivismo, restando adequar o grau da regulagem e da mudança radical. 
Para Gioia e Pitre (1990, p. 595, tradução minha), “parece, então, que os paradigmas não são completamente incomensuráveis, porque há maneiras de entender coisas importantes do ponto de vista de um paradigma em termos do outro, incidindo sobre as zonas de transição". O que não significa, entretanto, que todos os paradigmas possam ser integrados, visto que não há zonas de transição entre eles, como ocorre entre o estruturalismo radical e o interpretativo e, também, entre o humanismo radical e o funcionalista.

Apesar de ser uma visão ainda bastante tímida - e, até certo ponto, engessada - sobre o movimento paradigmático, Gioia e Pitre (1990) trouxeram à tona a ideia de zonas transição para o debate, nos permitindo um novo olhar sobre os paradigmas, agora não mais como uma caixa hermética. A partir disso, os paradigmas passam a ser vistos, por alguns teóricos pluralistas, como verdades parciais e a metateorização os ajudam "a explorar padrões que fazem ligações entre entendimentos conflitantes”, afirmam Lewis e Grimes (2007, p. 40). “A pesquisa multiparadigmática assegura a preservação e legitimação de pontos de vista que, de outra forma, seriam percebidos como marginais ou, ainda, suprimidos pela ortodoxia dominante" (HASSARD; KELEMEN; WOLFRAM-COX, 2008, p. 7, tradução minha).

É importante lembrar que o esquema analítico de Burrel e Morgan (2005) foi criado dentro de uma visão de ciência moderna, baseada nas ideias iluministas de razão e progresso e, portanto, a partir de pressupostos ontológicos, epistemológicos e ideológicos que são considerados científicos dentro dessa perspectiva. "Enquanto paradigmas promovem pressupostos epistemológicos específicos, posturas modernas e pós-modernas oferecem variadas perspectivas sobre a natureza da epistemologia", lembram Lewis e Kelemen (2002, p. 253, tradução minha). Assim, não são reconhecidos pelos pós-modernos, visto que seu papel é desafiar os dogmas e suposições existentes, inclusive os ontológicos, epistemológicos, e ideológicos que sustentam o esquema de Burrel e Morgan (2005). Para Alvesson e Deetz (2006, p. 255):

O papel de pesquisa pós-moderna é muito diferente dos papéis tradicionais, atribuídos à ciência social. Ele serve primeiramente para tentar abrir a indeterminação que a ciência social moderna, as concepções cotidianas, as rotinas e as práticas têm fechado. 
A perspectiva multiparadigmática surgiu como uma primeira tentativa de se libertar dos paradigmas modernos sem, no entanto, aderir às ideias pós-modernas. Não se trata, no entanto, do "vale tudo" pós-moderno, uma vez que a perspectiva multiparadigmática não adere nem a visão da ciência moderna para a ordem e a estabilidade, nem a visão pósmoderna de fragmentação e fluxo (LEWIS; KELEMEN, 2002). Assim, a partir dos "tiposideais" de modernos, pós-modernos e multiparadigmáticos, Lewis e Kelemen (2002) apresentam os contrastes entre essas abordagens, mostrando como esses últimos estão em uma posição intermediária (Quadro 1).

\begin{tabular}{|c|c|c|c|}
\hline & Moderno & Multiparadigmático & Pós-moderno \\
\hline \multirow[t]{2}{*}{ Ideologia } & Centralização & Acomodação & Descentralização \\
\hline & $\begin{array}{l}\text { Se concentra na autoria, na } \\
\text { promoção de vozes escolhidas e } \\
\text { crenças. Foca em questões } \\
\text { seletivas. }\end{array}$ & $\begin{array}{l}\text { Valoriza lentes divergentes entre } \\
\text { paradigmas. Explora o paradoxo } \\
\text { e a pluralidade. }\end{array}$ & $\begin{array}{l}\text { Discursos fragmentados. Acentua } \\
\text { a diferença e a incerteza. }\end{array}$ \\
\hline \multirow[t]{2}{*}{ Ontologia } & Forte & Estratificado & Fraco \\
\hline & $\begin{array}{l}\text { Estado do ser. } \\
\text { Paradigmas são distintos, } \\
\text { determinados e compreensíveis. }\end{array}$ & $\begin{array}{l}\text { Múltiplas dimensões. } \\
\text { Interação entre paradigmas e } \\
\text { processos. }\end{array}$ & $\begin{array}{l}\text { Em processo de se tornar. } \\
\text { Significados são indeterminados, } \\
\text { em constante fluxo e } \\
\text { transformação. }\end{array}$ \\
\hline \multirow[t]{2}{*}{ Epistemologia } & Restrito & Pluralista & Eclético \\
\hline & $\begin{array}{l}\text { Emprega prescrições do } \\
\text { paradigma sistematicamente. } \\
\text { Constrói representações coesas } \\
\text { para promover o } \\
\text { desenvolvimento do paradigma. }\end{array}$ & $\begin{array}{l}\text { Aplica lente de paradigmas. } \\
\text { Reflete tensões organizacionais e } \\
\text { incentiva uma maior } \\
\text { reflexividade. }\end{array}$ & $\begin{array}{l}\text { Usa métodos variados } \\
\text { livremente. } \\
\text { Promove a desconstrução de } \\
\text { contextos e processos de } \\
\text { produção de pequenas histórias } \\
\text { ou narrativas organizacionais } \\
\text { modestas. }\end{array}$ \\
\hline
\end{tabular}

Quadro 1 - Abordagens alternativas

Fonte - Lewis e Kelemen (2002, p. 254).

Assim, segundo Lewis e Kelemen (2002, p. 258, tradução minha), a perspectiva multiparadigmática tem como objetivo "promover uma maior sensibilização de alternativas teóricas e, assim, facilitar o discurso e/ou a consulta através de paradigmas e [...] promover uma maior compreensão da pluralidade e do parodoxo organizacional". Aqueles que se

\footnotetext{
${ }^{3}$ Talvez seja interessante esclarecer que o termo "vale tudo" não carrega, aqui, qualquer valor negativo, uma vez que está ancorado nas ideias de Feyerabend (1977) de que a única forma de avançar no conhecimento é por meio do "vale tudo".
} 
utilizam da perspectiva multiparadigmática, os chamados de pluralistas ${ }^{4}$, promovem uma acomodação ideológica, avaliando o potencial de aplicação dos conceitos e técnicas desenvolvidos em diferentes paradigmas, ao mesmo tempo em que defendem a ontologia estratificada que "assume múltiplas dimensões de realidade" e, por fim, repudia uma única forma de conceber o mundo advogando pelo pluralismo epistemológico. Conforme defende Lewis e Kelemen (2002, p. 259, tradução minha):

Como cada lente oferece um foco seletivo, os pesquisadores procuram múltiplas perspectivas, particularmente sobre os fenômenos complexos e ambíguos. Contrastando representações modernas, que permitem entendimentos mais perspicazes - por exemplo, forças reveladoras puxando em direção à complacência e à resistência, empoderamento e disciplina.

Para Paula (2016, p. 32), no entanto, não faz sentido, em Estudos Organizacionais, continuarmos nos baseando em uma lógica explicativa claramente kuhniana, já que nesta área “os conflitos não se dão em torno de questões de premissas que envolvem medidas e técnicas, mas principalmente de posições ideológicas e políticas”. Assim, se inspirando na ideia de Habermas de que o conhecimento se dá a partir da conjunção dialética dos interesses cognitivos técnico, prático e emancipatório, Paula (2016) propõe a utilização do Círculo das Matrizes Epistêmicas. No lugar da rígida figura quadrada em que estão dispostos os quatro paradigmas, é apresentado um círculo composto de matrizes epistêmicas, mais orgânico e flexível. Segundo Paula (2016, p. 36):

A escolha do círculo [...] partiu da intenção de colocar as matrizes como parte de um
todo integrado do conhecimento, uma vez que os interesses cognitivos não deveriam
ser compreendidos como concorrentes, mas complementares, pois o funcionamento
da vida social depende de todos eles. [...] O quadrado é comumente associado ao
pensamento cartesiano, analítico e mecânico, indicando precisão, cálculo e perfeição
matemática. Ele ainda simboliza a interrupção do movimento, pois os ângulos
indicam descontinuidade no fluxo, inércia e limitação. O quadrado ainda é uma
forma construída que não se encontra na natureza, também remetendo à rigidez,

\footnotetext{
${ }^{4}$ Esses teóricos passam a ser chamados de pluralistas, em oposição aos integracionistas e protecionistas, aqueles que abandonaram a tese da incomensurabilidade a favor do engajamento em pesquisas multiparadigmáticas (HASSARD; KELEMEN, 2002). Segundo Hassard e Kelemen (2002), o debate no campo da análise organizacional se dá entre (1) os não-consumidores, aqueles que não estão conscientes do debate epistemológico, (2) os integracionistas, que defendem a produção de um paradigma integrado a partir de uma coordenação que decidirá o padrão metodológico único para o campo; (3) os protecionistas, aqueles que defendem a incomensurabilidade dos paradigmas, (4) os pluralistas, que defendem os estudos multiparadigmáticos e (5) os pós-modernistas, que defendem a necessidade de maior liberdade e ecletismo, na base do "vale tudo".
} 
estabilidade e ordem. O círculo, por sua vez, é associado ao pensamento orgânico, relacionando-se ao incalculável e ao natural. Ele simboliza a fluidez livre e sem interrupções. O círculo é uma forma abundante na natureza e faz referência à flexibilidade, ao infinito, ao limitado e à ideia de totalidade.

No Círculo das Matrizes Epistêmicas proposto por Paula (2016) estão dispostas três matrizes: a) a matriz empírico-analítica, que se alinha, em grande parte, ao pensamento positivista, empírico e formal, mas também com autores considerados não positivistas, como Weber e alguns marxistas, já que se orienta pela filosofia positiva, o uso da lógica formal e o interesse técnico; b) a matriz hermenêutica se caracteriza pela compreensão do sentido, se alinhando à lógica interpretativa e ao interesse prático, como nas abordagens fenomenológicas, linguísticas e hermenêuticas; c) a matriz crítica abriga as abordagens orientadas pela filosofia negativa, a lógica dialética e o interesse emancipatório.

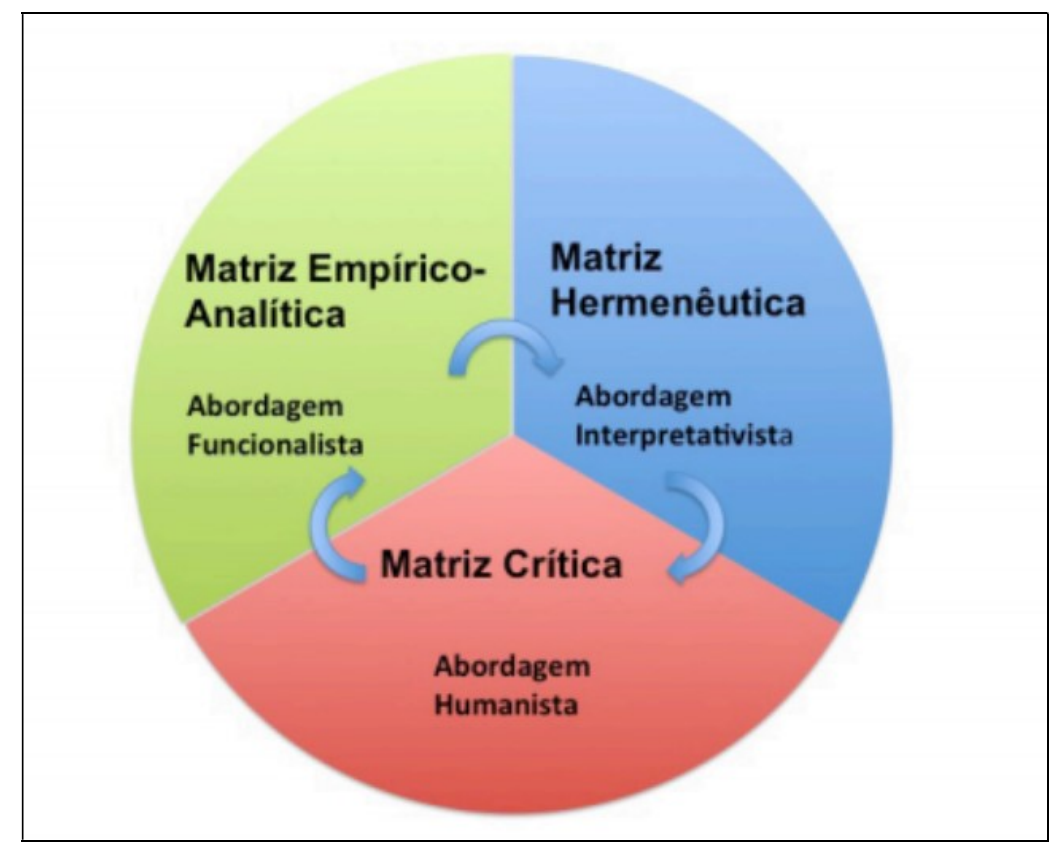

Figura 3 - Círculo das Matrizes Epistêmicas

Fonte - Paula (2016, p. 42).

Paula (2016, p. 37) deixa claro que "as matrizes apresentadas não devem ser tomadas como instâncias que aprisionam as abordagens sociológicas, mas sim como partes constituintes de um todo integrado da produção do conhecimento", sendo, portanto, comum abordagens sociológicas híbridas que, ao buscarem superar a incompletude cognitiva, transitam entre as matrizes. 
E é justamente nessa linha que concebo esta tese, rejeitando a incomensurabilidade paradigmática e buscando o hibridismo sociológico, mesmo assumindo as dificuldades de aceitação desta que ainda é vista por muitos na academia como uma "heresia". Assumo, portanto, uma visão pluralista e orgânica, na medida em que, defendem Lewis e Kelemen (2002) e Paula (2016), é mais voltada para a complexidade organizacional do que o enclausuramento paradigmático que, muitas vezes, não fornece os constructos teóricos suficientes para esclarecer os fenômenos. Como escreve Bourdieu (2004a, p. 26, grifo do autor):

\begin{abstract}
A pesquisa é uma coisa demasiado séria e demasiado difícil para se poder tomar a liberdade de confundir a rigidez, que é o contrário da inteligência e da invenção, com o rigor, e se ficar privado deste ou daquele recurso entre os vários que podem ser oferecidos pelo conjunto das tradições intelectuais da disciplina - e das disciplinas vizinhas.
\end{abstract}

Assim, conforme as questões se apresentam, lanço mão de autores que são classificados muitas vezes de forma estimagtizada ${ }^{5}$ - como pertencentes a diferentes abordagens sociológicas, contanto que eles me ajudem a compreender o fenômeno como ele se apresenta. Sigo, então, a mesma postura de Bourdieu (2004b, p. 42) quando ele esclarece a sua orientação epistemológica afirmando que "de minha parte, mantenho com os autores uma relação muito pragmática: recorro a eles como 'companheiros', no sentido da tradição artesanal, como alguém a que se pode pedir uma mão nas situações difíceis”.

O que não significa que faço isto de uma forma leviana, utilizando os conceitos sem qualquer reflexão sobre as contradições e convergências, visto que tento seguir o conselho de Amboni e Carminha (2014, p. 12) de que "a reflexividade ancorada no diálogo, na contextualização e na interdisciplinaridade deve permear todo o processo de análise multiparadigmática, visando minimizar os seus limites”. Desta forma, antes do momento da análise, que não se abstém da reflexividade, é preciso construir o aporte teórico multiparadigmático de forma reflexiva, mais crítica e menos intransigente e rígida. "Para tanto, é preciso romper fronteiras, evitar o

\footnotetext{
${ }^{5}$ Para Bourdieu (2004b, p. 42), "saber se um autor é marxista, durkheimiano ou weberiano não acrescenta praticamente nenhuma informação sobre esse autor. Acho inclusive que um dos obstáculos ao progresso da pesquisa é esse funcionamento classificatório do pensamento acadêmico - e político -, que muitas vezes embaraça a invenção intelectual, impedindo a superação de falsas antinomias e de falsas divisões. A lógica do rótulo classificatório é exatamente a mesma do racismo, que estigmatiza, aprisionando numa essência negativa. Em todo caso, ela constitui, a meu ver, o principal obstáculo ao que me parece ser a relação adequada com os textos e pensadores do passado".
} 
egocentrismo e criar um clima de convivência que possibilite o reconhecimento de diversas posições metateóricas", defendem Silva e Roman Neto (2006, p. 85).

\subsection{A escolha do objeto de pesquisa}

A escolha do objeto de pesquisa não está livre dos valores do pesquisador e, portanto, não é somente racional e deliberada, mas, sobretudo, se dá pelo envolvimento inconsciente com o fenômeno. Para Sant'Ana (2010, p. 372):

Hoje é amplamente aceito que nenhuma área do conhecimento pode escapar das dificuldades produzidas pela subjetividade do investigador, pois este, ao escolher o objeto de sua investigação, já traz consigo a influência do seu contexto de inserção, de seus grupos de referência, de suas preferências intelectuais do momento e de suas idiossincracias.

Desta forma, a produção do conhecimento é um ato político. E não há nenhuma vergonha em assumir isso. Pelo contrário, vergonhoso é tentar impor uma pretensa neutralidade das ciências sociais, sustentada pela separação entre o pesquisador e seu objeto de pesquisa, tentando esconder aquilo que já foi desnudado. Concordo com Saraiva $(2014$, p. 8) quando ele diz que "quem produz conhecimento [...] o faz a partir de um determinado lugar, que tem a ver com sua origem, sua experiência, cognição, com a história e relações sociopolíticas”. Assim, penso ser importante, antes de falar especificamente do meu objeto de pesquisa, tentar expor um pouco sobre minhas preocupações, sobre meus interesses, sobre o que me empurra pra frente. Eu escrevo "tentar" pois, como já dizia Lacan (1999), podemos ser tão ou mais ignorantes quanto as outras pessoas com relação ao que somos.

Uma das grandes questões que sempre me incomodou, ainda como aluna de graduação do curso de Administração, foi a visão restrita ao gerencialismo, a uma ciência e uma prática sempre comprometidas somente com os aspectos econômicos da organização. Enfim, "uma disciplina que nasce no mercado e para o mercado, que tem na sua origem e como razão de ser a produção de conhecimento para aperfeiçoar a organização do capital”, como defende o Grupo de pesquisa Organização e Práxis Libertadora (2014, p. 252), ligado ao Programa de Pós-Graduação em Administração da Universidade Federal do Rio Grande do Sul. 
Desta forma, me dedico a pesquisar as organizações inseridas na sociedade e não apartadas dela - como organismos estranhos à dinâmica social e que, portanto, operam dentro de uma racionalidade estritamente econômica (SARAIVA, 2014). Foi dessa forma que, desde o mestrado, mergulhei na interface entre as organizações e a sociedade, rejeitando a naturalidade da perspectiva instrumental do management. Não quero com isso dizer que não veja importância na dimensão operacional das organizações, mas que além dela há questões mais importantes, as pessoas, dentro e fora das organizações, que sofrem os efeitos das decisões organizacionais. Com isso, quero dizer que as organizações não podem ser vistas como uma forma destituída da sociedade e, portanto, da história dos sujeitos, dos significados construídos e das relações de poder instituídas. Ou seja, me preocupo basicamente com a vida organizada a partir dos interesses das organizações capitalistas. Como escreve Carrieri (2014, p. 20):

\footnotetext{
A vida organizada quer expressar as múltiplas relações dos homens uns com os outros na produção e reprodução de sua existência humano-societária. A atenção do pesquisador não esta focada em uma ou outra organização particular, mas nas relações da(s) organização(ões) com a vida organizada; considerando esta vida como constituída historicamente, e como resultante de múltiplas relações de poder que perpassam, caracterizam e constituem o corpo social.
}

É assim que passei a me preocupar com os desdobramentos socioambientais das usinas hidrelétricas sobre a sociedade e os sujeitos ao seu redor, não só de forma objetiva, mas principalmente de forma subjetiva, modificando o modo como as pessoas enxergam o mundo, suas relações entre si e com o espaço. Rejeito, portanto, uma dinâmica que não leva em consideração as pessoas simplesmente como seres humanos, mas como coisas, peças de uma engrenagem em nome de um pretenso progresso (pelos quais os locais não são chamados a opinar).

Infelizmente, não é essa a linha que domina os estudos na Administração, um campo profundamente comprometido com a disseminação de uma forma homogênea de gerir, orientado pela busca incessante de lucro, do desempenho máximo, do controle, dissociado, portanto, da ideia de Administração como projeto social (AKTOUF, 2005).

Mas, apesar de incipiente, é possível encontrar estudos na área de conhecimento em Administração, mais especificamente em Estudos Organizacionais, que enxergam o fenômeno 
com uma lente diferente, mais preocupados com os desdobramentos gerados pelo management no modo de vida das pessoas, as formas de resistência a ele e com o surgimento de organizações produtivas e sociais que não são orientadas pelas suas normas (BARROS; CARRIERI, 2015; MISOCZKY; VECCHIO, 2006; PRESTES MOTTA, 1992).

É nessa linha que concebo esta tese, refletindo sobre como hoje o management, de tão naturalizado, se torna um modelo de ação para todas as organizações, prometendo o seu desenvolvimento, mesmo que para isso torne-se uma forma de dominação das diferentes formas de vida. Para isso, estudo a criação e a implantação de um programa de desenvolvimento em uma comunidade indígena, resultado de uma indenização pela construção e operação de uma pequena usina hidréletrica no Paraná. Falo aqui do Programa de Desenvolvimento Socioeconômico e Ambiental da Terra Indígena Apucaraninha, denominado Vehn Kar, voltado à implementação de mudanças sociais, econômicas e ambientais na comunidade, "visando ao bem estar de suas presentes e futuras gerações e à sua sustentabilidade socioeconomica cultural e ambiental", conforme Termo de Referência assinado pela COPEL, Companhia Paranaense de Energia, proprietária da Usina Hidrelétrica de Apucaraninha, o MPF, Ministério Público Federal, e as lideranças indígenas representantes da comunidade (TERMO..., 2009, p. 2).

O programa, como veremos adiante, foi criado como condicionante para que a comunidade indígena recebesse grande parte do valor da indenização. Assim, em um prazo de 25 anos, os consultores e os participantes não-indígenas do programa iriam atuar na comunidade indígena visando torná-los autossustentáveis, de forma que não dependessem mais da tutela e ajuda financeira dos "brancos".

O problema é, prometendo sua libertação, acabam por impor aos índios uma nova lógica econômica e social baseada no management, já que a forma de vida indígena, conforme a imagem que os "brancos" desenvolveram deles, é considerada indesejável por ser improdutiva. Desta forma, disseminam a ideologia do management, principalmente entre as lideranças, ávidas pelo "progresso" que vislumbram na sociedade envolvente, atuando sobre suas subjetividades e, portanto, sobre a relação que mantêm sob suas condições objetivas de vida, o que resulta em novas formas de comportamento e novas relações, como pode ser visto no Quadro de Referência Teórico a seguir (figura 4). 
Inicialmente eu estava interessada em como se dava o conflito entre a lógica do management - e sua noção de progresso - e o espaço vivido no processo de apropriação do território para a construção da Usina Hidrelétrica de Apucarinha. Mas, nas minhas visitas à comunidade, foi ficando claro para mim que a usina, por ter entrado em funcionamento há mais de 60 anos, não era vista como um elemento externo, já que a maior parte dos indígenas já nasceu a tendo como vizinha. É assim que cresceram pescando nos reservatórios e escalando a tubulação da usina.

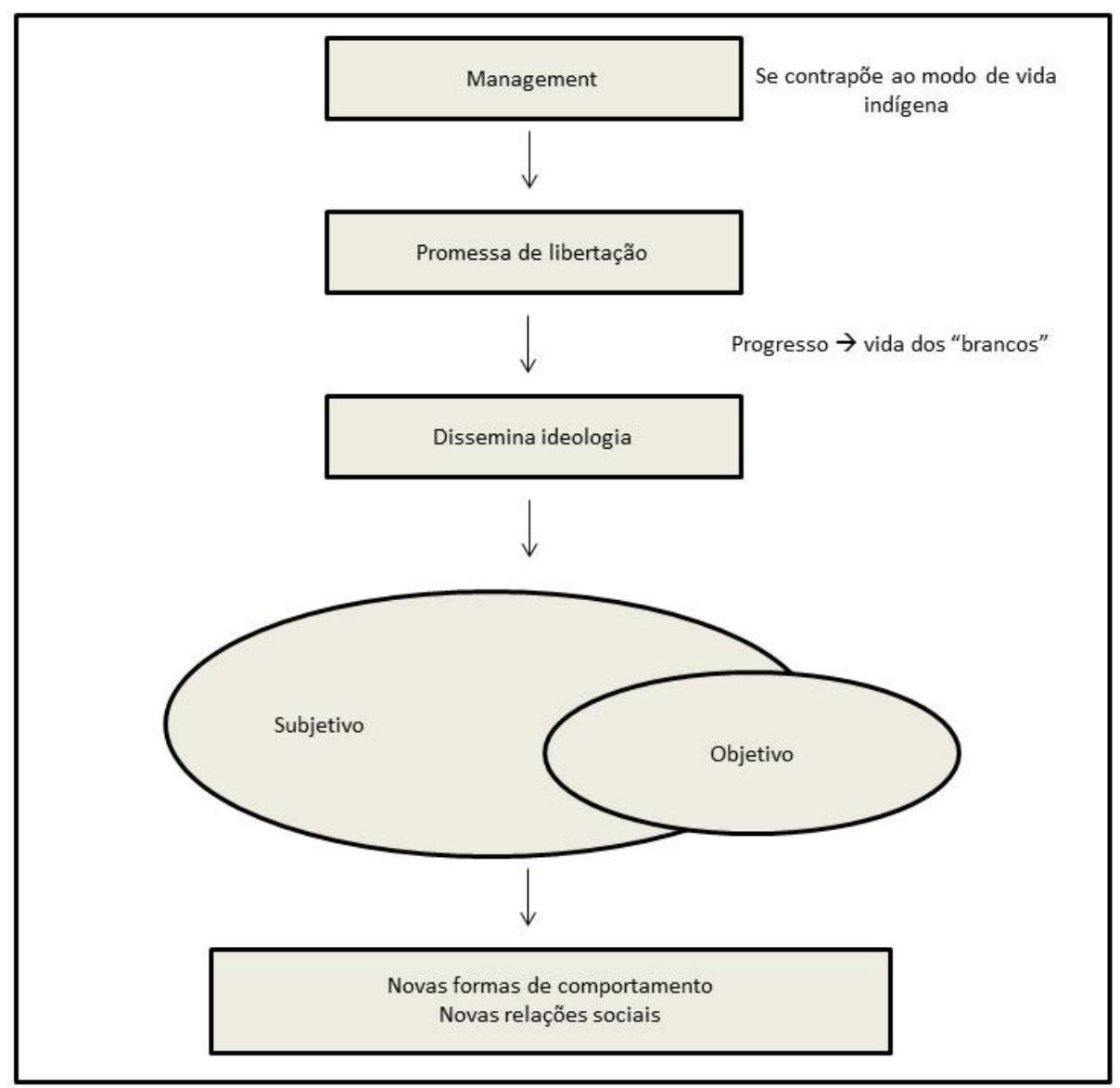

Figura 4 - Quadro de Referência Teórica

Fonte - Elaborado pela autora.

$\mathrm{Na}$ verdade, pude perceber nas falas dos Kaingang de Apucaraninha que a usina só se torna um elemento importante quando se vislumbra a ideia de que eles poderiam ser indenizados pela sua construção e funcionamento, na medida em que eles ainda não têm noção dos impactos socioculturais, ambientais e econômicos que a usina causou à comunidade. Esta 
ideia deve ser mais bem investigada, uma vez que ela não faz parte do meu estudo, mas esta é uma percepção que eu tive durante todo o tempo que estive na terra indígena. Já o Programa de Desenvolvimento era central nas suas falas, principalmente porque muitos dos entrevistados indígenas acreditam que foram enganados pelas promessas que fizeram a eles. Assim, acabei por modificar o objetivo deste estudo tendo agora o programa como objeto.

\subsection{A pesquisa de campo}

Em um estudo qualitativo, o fenômeno deve ser analisado em uma perspectiva integrada. "Para tanto, o pesquisador vai a campo buscando 'captar' o fenômeno em estudo a partir da perspectiva das pessoas nele envolvidas, considerando todos os pontos de vista relevantes" (GODOY, 1995, p. 21). Isso porque, segundo Saquet, Candiotto e Alves (2010), um dos grandes desafios de pesquisas em que os processos territoriais têm ampla relevância, é desvendar às intrincadas relações e dimensões a eles relacionadas.

Desta forma, para a coleta de dados utilizei a entrevista semiestruturada, o grupo focal e a análise documental e bibliográfica. O objetivo foi "vivamente recolher o máximo de informações pertinentes” (DESLAURIERS; KÉRISIT, 2010, p. 140). Levei em consideração que o campo não iria apenas responder às minhas perguntas, mas, principalmente, me apresentar novas questões, "surpreendentes sob alguns aspectos, mas, geralmente, mais pertinentes e mais adequadas" do que as inicialmente colocadas, conforme Deslauriers e Kérisit (2010, p. 148).

A escolha da entrevista como técnica de coleta de dados se deu pela possibilidade de explorar em profundidade as experiências dos sujeitos da pesquisa o que tornaria a imersão no espaço social mais aprofundado. Segundo Poupart (2010, p. 216):

Do exame das justificativas habitualmente alegadas pelos pesquisadores para recorrer à entrevista de tipo qualitativa, três tipos de argumentos se destacam. $\mathrm{O}$ primeiro é de ordem epistemológica: a entrevista do tipo qualitativo seria necessária, uma vez que uma exploração em profundidade da perspectiva dos atores sociais é considerada indispensável para uma exata apreensão e compreensão das condutas sociais. O segundo tipo de argumento é de ordem ética e política: a entrevista do tipo qualitativo parece necessária, porque ela abriria a possibilidade de compreender e conhecer internamente os dilemas e questões enfrentados pelos atores sociais. 
Destacam-se, por fim, os argumentos metodológicos: a entrevista do tipo qualitativo se imporia entre as "ferramentas de informação" capazes de elucidar as realidades sociais, mas, principalmente, como instrumento privilegiado de acesso à experiência dos atores.

Inicialmente, fui a campo com a pretensão de somente fazer entrevistas semiestruturadas, preferindo não partir de questões prontas justamente porque gostaria de deixar a entrevista avançar de forma aberta e dialógica, utilizando somente blocos básicos de aspectos a serem abordados, sem que nenhuma pergunta estivesse pré-estabelecida. A ideia foi deixar a entrevista fluir dentro dos blocos, mas tendo a liberdade de fazer as perguntas que eu, conforme a relação estabelecida com o entrevistado, achasse mais relevante. Com base nisso, foram elaborados dois instrumentos de coleta de dados baseados em blocos temáticos, um deles voltado para indígenas (Apêndice A) e o outro, para não-indígenas (Apêndice B). O roteiro semiestruturado direcionado aos indígenas contou com os seguintes blocos temáticos:

Bloco 1 - $\mathrm{O}(\mathrm{a})$ entrevistado(a)

Bloco 2 - A Terra Indígena de Apucaraninha

Bloco 3 - A usina hidrelétrica de Apucaraninha

Bloco 4 - A indenização

Bloco 5 - O projeto de sustentabilidade

Bloco 6 - O futuro

O roteiro semiestruturado direcionado aos não-indígenas, por sua vez, contava com os seguintes blocos temáticos:

Bloco 1 - $\mathrm{O}$ (a) entrevistado(a)

Bloco 2 - A Terra Indígena de Apucaraninha

Bloco 3 - O Projeto de Sustentabilidade

Bloco 4 - O futuro

Para os não-indígenas foram excluídos os blocos temáticos relativos à usina hidrelétrica e à indenização, uma vez que para essas categorias bastava a visão dos indígenas, diretamente envolvidos com elas. 
Esta técnica de pesquisa precisou ser adaptada ao campo, posto que, por duas vezes, tive que utilizar o grupo focal, técnica de pesquisa que consiste na coleta de dados "por meio das interações grupais ao se discutir um tópico especial sugerido pelo pesquisador" (GONDIM, 2003, p. 151), devido às necessidades dos entrevistados e da comunidade em estudo. Em todo caso, a base do instrumento de coleta de dados foi utilizada, apesar de adaptada ao contexto.

Na primeira vez, dois consultores decidiram dar as entrevistas juntos, já que trabalhavam há muito tempo no mesmo laboratório de pesquisa. Para esta entrevista, fui preparada para fazer uso das técnicas do grupo focal, já que estava ciente que meu papel naquele momento seria mais de mediadora da conversa do que de entrevistadora.

Na segunda, no entanto, fui pega de surpresa. Ao estar na Terra Indígena no dia de uma reunião do Programa de Sustentabilidade, encontrei muitos índios reunidos na sede do programa antes do almoço - a reunião estava marcada para começar às 13 horas. Eu tinha ido procurar o cacique eleito para entrevistá-lo. $\mathrm{Eu}$ o encontrei e ele aceitou me dar uma entrevista, me levando para uma sala no fundo do prédio. No entanto, ele foi chamado pelos outros índios que estavam ali reunidos que pediram que eu falasse com todos ao mesmo tempo. Sendo assim, fui colocada em um pequeno auditório, frente a frente, com cerca de 20 índios, a maioria deles lideranças ligadas ao cacique recém-eleito. Minha saída foi lançar mão do grupo focal.

É claro que nem todos falaram durante a nossa conversa. Na verdade, somente as lideranças e os mais idosos, um total de cinco pessoas, emitiram suas opiniões, todos homens. A única mulher que eu pude ver entre os presentes só balançava a cabeça concordando com o que os outros falavam, mas não emitiu qualquer opinião oralmente. Como eu não fazia perguntas diretamente a cada um dos presentes, não me senti à vontade de fazer qualquer indagação a essa senhora. Aliás, eu também corria o risco de, ao fazer isso, quebrar a hierarquia indígena, que é bastante rígida e centrada na figura masculina. Preferi não indagá-la, então.

Assim, participaram deste estudo 21 pessoas, entre não-índios do Programa de Sustentabilidade e indígenas, escolhidos pela sua relação com o processo que deu início à indenização e/ou com o Programa de Sustentabilidade na Terra Indígena Apucaraninha, conforme quadro 2. É assim que busquei cobrir os diversos segmentos envolvidos com o meu objeto: a) os consultores, b) os representantes da COPEL, Companhia Paranaense de Energia, 
c) os representantes do Ministério Público Federal e d) os indígenas. Em média, as entrevistas duraram cerca de duas horas cada, sendo todas gravadas e, posteriormente, transcritas, resultando no total de 511 páginas.

Nas primeiras entrevistas, escolhi consultores de áreas disciplinares diferentes que atuaram na primeira fase do programa, assim chamado de diagnóstico ${ }^{6}$. Durante as entrevistas eles foram me indicando participantes dessa primeira fase do programa, em um efeito bola de neve. Os indígenas foram abordados em um segundo momento, quando me dirigi à comunidade e, com a ajuda de um sociólogo que trabalha há tempos nas aldeias e mantém bom relacionamento com eles, procurei informantes-chave.

\begin{tabular}{|c|c|c|c|c|}
\hline & Nome $^{7}$ & Profissão/Ocupação & Segmento & Papel no Programa \\
\hline 1 & Alberto & Professor universitário/Administração & Consultor & Consultor no diagnóstico \\
\hline 2 & Sílvio & Professor universitário/Economia & Consultor & Consultor no diagnóstico \\
\hline 3 & José & Professor universitário/Biologia & Consultor & Consultor no diagnóstico \\
\hline 4 & Luciano & Membro do MPF & MPF & Intermediação e proteção dos direitos \\
\hline 5 & Gisele & Antropóloga & MPF & Intermediação e proteção dos direitos \\
\hline 6 & Fábio & Professor universitário/História & Consultor & Consultor no diagnóstico \\
\hline 7 & Carlos & Professor universitário/Agronomia & Consultor & Consultor no diagnóstico \\
\hline 8 & Elisa & Professora universitária/Antropologia & MPF & Treinamento dos consultores \\
\hline 9 & Juliana & Socióloga & COPEL & Coordenadora do Programa $-2^{a}$ fase \\
\hline 10 & Marcelo & Sociólogo & Consultor & Facilitador de campo no diagnóstico \\
\hline 11 & Joana & Antropóloga & Consultor & Coordenadora do Diagnóstico \\
\hline 12 & Wilson & Advogado & COPEL & Assessoria técnica $-1^{\mathrm{a}}$ e $2^{\mathrm{a}}$ fases \\
\hline 13 & João & Não informado & Indígena & Liderança \\
\hline 14 & Miguel & Não informado & Indígena & Administração interna \\
\hline 15 & Francisco & Agricultor & Indígena & Liderança \\
\hline 16 & Joaquim & Agricultor & Indígena & Comunidade \\
\hline 17 & Davi & Não informado & Indígena & Liderança \\
\hline 18 & Emanuel & Não informado & Indígena & Liderança \\
\hline 19 & Antônio & Não informado & Indígena & Comunidade \\
\hline 20 & Bruno & Comerciante & Indígena & "Branco" que mora na aldeia \\
\hline 21 & Benjamin & Não informado & Indígena & Comunidade \\
\hline
\end{tabular}

Quadro 2 - Participantes selecionados para a pesquisa

Fonte - Elaborado pala autora.

Aqui é importante esclarecer que, como já tinha sido avisada por uma antropóloga, tive dificuldades para acessar os índios que não estão envolvidos com as lideranças. O problema é que somente os que falam bem o português transitam com mais naturalidade pelo "mundo dos

\footnotetext{
${ }^{6}$ Conforme informações obtidas em campo, o Programa foi desenhado para ser desenvolvido em duas etapas. A primeira, o Diagnóstico Socioeconômico e Cultural, feitos pelos consultores, seria utilizado para levantar os aspectos sociais, ambientais, econômicos e culturais da Terra Indígena Apucaraninha. Em seguida, os resultados obtidos na primeira fase seriam utilizados para subsidiar os projetos sustentáveis nestas mesmas áreas. Assim, numa primeira fase, seriam feitos os levantamentos para, em seguida, serem colocados em prática.

${ }^{7}$ Todos os nomes foram trocados para proteger a identidade dos entrevistados.
} 
brancos", se tornam líderes ou estão fortemente relacionados a eles, já que falar a língua da sociedade envolvente é uma das características almejadas nas lideranças, conforme levantado por Almeida (2014) entre os Kaingang.

Além do mais, grande parte das lideranças é do sexo masculino e, assim, não consegui contato com lideranças mulheres. A única que tentei entrevistar não estava na comunidade indígena nos dias que estive por lá. Além do mais, como se trata de uma liderança da ala oposta à do cacique atual (e do que tinha acabado de ser eleito), fui alertada para os perigos de como esse contato seria visto pelo seu grupo. Assim, achei melhor abrir mão desta entrevista.

É interessante notar que entre os entrevistados "brancos", todos possuem curso superior e estão trabalhando na sua área de formação. Enquanto, entre os indios, nenhum possui curso superior, tendo a maioria estudado até os primeiros anos do ensino básico, sendo alguns analfabetos. Somente um dos entrevistados, Miguel, conseguiu terminar o ensino médio e, apesar de ter sido aprovado no vestibular indígena por três vezes, ainda não conseguiu fazer um curso superior porque, em suas palavras, precisam de seus conhecimentos na comunidade. Ainda assim, Miguel tem dúvidas se deve abrir mão do que deseja fazer ou se dedicar a sua comunidade: "mas eu fico pensando: será que eu devo fazer conforme a minha vontade ou conforme a vontade dos outros? O que vai acontecer? Eu fico pensando".

Não fui a campo com um número pré-definido de entrevistados. No entanto, me preocupei, a todo o momento, em distribuir as entrevistas entre os representantes dos diversos segmentos, para assegurar a não concentração das vozes em um só deles e restringir as de outros. É claro que esta divisão não poderia ser equânime, já que a quantidade de envolvidos de um segmento não é igual à de outro. Por isso o Ministério Público e a COPEL possuem menos entrevistados do que as universidades e os indígenas, numericamente superiores no programa. Optei por parar as entrevistas no momento em que senti que elas estavam se repetindo.

Para dar suporte as entrevistas, utilizei outras ferramentas que me permitiram interpretar o contexto como ele se apresenta. Assim, analisei documentos oficiais produzidos pelo MPF, pela COPEL e pelo grupo de consultores, como relatórios técnicos, Termos de Referência (TR), Termo de Ajustamento de Conduta (TAC) e o relatório do diagnóstico produzido pelos consultores na primeira fase do programa. Também trabalhei com textos de jornais e revistas 
e, como não poderia deixar de ser, com artigos, teses e dissertações que me forneceram subsídios para entendimento do contexto social e político.

Dado que uma pesquisa qualitativa requer um contato direto com o fenômeno pesquisado, seu objeto se constrói não apenas a partir de um corpus, por vezes restrito, de relatórios de pesquisas cujos resultados são verificados e confirmados, mas também a partir de um conjunto de textos que tecem como uma teia de ressonâncias em torno do objeto (DESLAURIERS; KÉRISIT, 2010, p. 135).

Tenho consciência que estes documentos, como qualquer outro, foram produzidos para comunicar um ponto de vista específico. Mas isso, ao invés de ser um problema, como aponta Godoy (1995), representa uma vantagem, pois me possibilita compreender a ideologia, já que ela é "constitutiva dos atos de dizer, posto que ela se define como o mecanismo que naturaliza sentidos para o sujeito, tornando-os evidentes, óbvios e naturais", afirma Romão (2007, p. 146).

Além deste material, lancei mão de um caderno de campo em que anotei minhas observações durante o período em que estive coletando os dados. Neste caderno, anotei fatos ocorridos nos momentos em que não estava entrevistando, como conversas que testemunhei entre alguns indígenas e o sociólogo que estava me acompanhando em campo, falas do próprio sociólogo no trajeto para a terra indígena, impressões que tive da dinâmica simbólica local, insights e dúvidas que surgiam durante a pesquisa.

Como muitas vezes as anotações, feitas rapidamente, foram efetuadas em "estado bruto". Mesmo aquelas que foram descritas, devido à falta de tempo, no momento em que eu retornava do trabalho de campo foram feitas a partir de anotações superficiais na hora do acontecimento. Assim, não houve preocupação de se fazer nenhuma seleção ou análise prévia. Só em um segundo momento, este caderno de campo foi objeto de análise, auxiliando na compreensão do fenômeno. 


\subsection{Proposta de análise}

Neste estudo, os dados coletados por meio de entrevistas e documentos foram interpretados sob a perspectiva dos elementos ${ }^{8}$ da Análise do Discurso (AD) de Linha Francesa, uma vez que "a palavra está sempre carregada de um conteúdo ou de um sentido ideológico ou vivencial", afirma Bakhtin (1986, p. 95). Não se trata, portanto, apenas de uma forma de transmissão de informações, já que na Análise do Discurso a linguagem é vista como "um complexo processo de constituição [dos] sujeitos e produção de sentidos", destaca Orlandi (1999, p. 21). Assim, a palavra não é neutra, posto que é carregada de ideologia de um horizonte social historicamente definido. Para Brandão (2004, p. 11):

\footnotetext{
A linguagem enquanto discurso não constitui um universo de signos que serve apenas como instrumento de comunicação ou suporte de pensamento; a linguagem enquanto discurso é interação, e um modo de produção social; ela não é neutra, inocente e nem natural, por isso o lugar privilegiado de manifestação de ideologia.
}

O termo discurso significa aqui, portanto, linguagem como constituinte do mundo social, por meio de textos escritos e falados, uma vez que a linguagem está investida de processos ideológicos muitas vezes desconhecidos pelas pessoas. Como afirma Orlandi (1994, p. 54), “é no discurso que se pode apreender a relação entre linguagem e ideologia, tendo a noção de sujeito como mediadora: não há discurso sem sujeito nem sujeito sem ideologia".

É assim que toda enunciação é determinada pela "situação social mais imediata e o meio social mais amplo" (BAKHTIN, 1986, p. 113). São os interlocutores, implícitos ou explícitos, que respondem pela situação social mais imediata, determinando o que será dito e como será dito. Assim, qualquer enunciação pressupõe a figura de um interlocutor, já que a palavra é "produto da interação do locutor e do ouvinte", afirma Bakhtin (1986, p. 113). Quando falamos, expressamos nossas palavras em relação a quem nos dirigimos.

Decorre daí, que toda pessoa se coloca “no lugar em que seu interlocutor 'ouve' suas palavras" (ORLANDI, 1999, p. 39, grifo da autora). Desta forma, o locutor cria imagens do outro, dentro de uma lógica sócio-histórica. De fato, a ideia que o locutor faz do outro conduz

\footnotetext{
${ }^{8}$ Souza e Carrieri (2014, p. 34) advertem os pesquisadores que conciliam a metodologia da AD "com outras teorias sociais e premissas ontológicas variadas" a utilizar a expressão "elementos da Análise do Discurso" para evitar "possíveis críticas à falta de fidelidade à tradição filosófica da disciplina".
} 
a sua fala e, é por isso, que ele produz uma imagem de si mesmo adequada ao estereótipo, segundo um estoque de imagens da cultura local, que ele imagina se encaixar ao seu interlocutor (AMOSSY, 2005). Assim, o pensamento não existe fora do meio social mais amplo. E o discurso possui uma dupla perspectiva.

\footnotetext{
Primeiro, interacional: a eficácia discursiva não pode ser compreendida fora da troca entre os participantes. Em seguida, uma perspectiva institucional: essa troca é indissociável das posições ocupadas pelos participantes no campo (religioso, político, intelectual, literário...) no interior do qual atuam (AMOSSY, 2005, p. 121, grifos da autora).
}

Para Bakhtin (1986, p. 121), "o centro organizador de toda enunciação, de toda expressão, não é interior, mas exterior: está situado no meio social que envolve o indivíduo". É assim que a fala não pode ser compreendida independente do contexto mais amplo que constitui as formas de vida de um determinado grupo social. Para Rodrigues e Dellagnelo (2013, p. 625):

\footnotetext{
Em decorrência disso, o processo entre a elaboração mental do conteúdo a ser externalizado à sua real subjetivação - a fala - tem seu conteúdo orientado socialmente, buscando adaptar-se ao contexto imediato do ato de comunicação e, principalmente, aos interlocutores.
}

Neste cenário, o sujeito é histórica, social e ideologicamente situado, afirma Brandão (2003), não sendo, em hipótese alguma, senhor absoluto do que diz. Todo discurso "é constituído a partir dos discursos alheios que the antecederam ou the sucederão, com os quais trava uma constante e produtiva interação" (MOZDZENSKI, 2010, p. 59). Todo discurso é voltado aos "outros discursos", sendo, de um lado, orientado pelos discursos produzidos pelo meio social mais amplo, e por outro, pelos que são produzidos pelo interlocutor. Este diálogo entre discursos é chamado, na Análise do Discurso, de dialogismo, e se assemelha ao conceito de interdiscurso. "O discurso se tece polifonicamente, num jogo de várias vozes cruzadas, complementares, concorrentes, contraditórias”, pontua Brandão (2004, p. 65).

Para Orlandi (1999, p. 33), interdiscurso é o já-dito, ou seja, "todo conjunto de formulações feitas e já esquecidas que determina o que dizemos" (ORLANDI, 1999, p. 33). Os sentidos da fala tem um componente histórico e, ao mesmo tempo, local. Assim, o interdiscurso resulta das relações entre formações discursivas que produzem sentidos ideológicos. É assim que 
uma mesma palavra tem significados diferentes conforme a formação discursiva, dado as diversas condições de produção. É desta forma que a palavra "progresso", por exemplo, tem significados diferentes para um grande produtor rural, um produtor familiar e um índio.

Podemos dizer que o sentido não existe em si mas é determinado pelas posições
ideológicas colocadas em jogo no processo sócio-histórico em que as palavras são
produzidas. As palavras mudam de sentido segundo as posições daqueles que as
empregam. Elas "tiram" seu sentido dessas posições, isto é, em relação às formações
ideológicas nas quais essas posições se inscrevem (ORLANDI, 1999, p. 42, grifo da
autora).

O papel daquele que analisa os dicursos é justamente entender quem fala - suas filiações sócio-históricas, como diria Pêcheux (1997) - e, a partir disso, compreender porque fala determinadas palavras e não outras. Palavras que estão embebidas nas ligações sóciohistóricas do sujeito e que permitem desvelar a produção dos discursos dentro de formações discursivas, que, segundo Orlandi (1999, p. 43), "determina o que pode e deve ser dito" em uma formação ideológica específica. Para Pêcheux (1997, p. 57), a ideia é que:

\footnotetext{
Através das descrições regulares de montagens discursivas, se possa detectar os momentos de interpretações enquanto atos que surgem como tomadas de posição, reconhecidas como tais, isto é, como efeitos de identificação assumidos e não negados.
}

A tomada de posição não é o resultado do "espírito" de uma época, mas existe dentro de um feixe de relações e deslocamentos (GREGOLIN, 2008). Esta heterogeneidade complica o momento da análise do discurso, pois o analista tem que contar com a instabilidade dos discursos. Assim, a diversidade de discursos disponíveis em um dado momento histórico só nos permite compreender a formação discursiva a partir da existência de trajetos temáticos, temas articulados que operam novos sentidos a partir dos já existentes.

Em termos analíticos o trajeto temático permite visualizar, no interior da dispersão do arquivo, momentos de regularidade, de sistematicidades que - embora instáveis permitem a inteligibilidade de certas escolhas temáticas num dado momento histórico (GREGOLIN, 2008, s/p). 
Um exemplo disso é dado por Gregolin (2008) quando ela analisa o discurso midiático sobre o casamento. Pelas imagens publicadas na imprensa brasileira impressa é possível verificar que o discurso sobre o casamento vai se alterando no tempo conforme as "redes de memória que dão lhe novos sentidos" (GREGOLIN, 2008, s/p). Assim, o discurso sobre o casamento é atualizado quando o novo e o velho se cruzam com outras séries de formulações, como os discursos relacionados ao papel masculino e feminino dominante naquela sociedade.

A memória aqui tem o mesmo conceito de interdiscurso, por isso é chamada de memória discursiva. "É sobre essa memória, de que não determos o controle, que nossos sentidos se constróem, dando-nos a impressão de que sabemos do que estamos falando. Como sabemos, aí se forma a ilusão de que somos a origem do que dizemos", aponta Orlandi (1999, p. 54).

É desta forma que, segundo Pêcheux (1997, p. 51), na AD é preciso estar atento aos dois espaços discursivos do discurso: a) "o da manipulação de significações estabilizadas"; b) "o de transformações do sentido". Para isso, é preciso abordar o equívoco, a falta, as contradições e alterações próprias da linguagem que permitem fluir o discurso, apesar da pressão exercida pela homogeneidade lógica discursiva ${ }^{9}$.

É por meio dessas falhas da língua que "todo enunciado é intrinsecamente suscetível de tornar-se outro, diferente de si mesmo, se deslocar discursivamente de seu sentido para derivar para um outro" (PÊCHEUX, 1997, p. 53). As falhas permitem as mudanças, a transformação do sentido dos discursos e, portanto, dos sujeitos. Isso porque os sujeitos se constituem nos discursos por meio do trabalho constante entre os sentidos, que são incompletos, e a sua própria história, fazendo com que os sentidos das palavras que retornam a nossa memória, mesmo que de forma inconsciente, são, algumas vezes, reconstruídos e passam a ter outros sentidos.

E para compreender os sentidos produzidos pelas palavras - escritas, faladas ou representadas por meio de imagens - é preciso construir um dispositivo analítico e um dispositivo teórico conforme o material que o analista tem em mãos, para tentar fugir da naturalidade da palavra,

\footnotetext{
9 Para Pêcheux (1997, p. 33, grifo do autor), além de o exterior - Estado e sociedade - impor espaços estabilizados, "o sujeito pragmático - isto é, cada um de nós, os 'simples particulares' face às diversas urgências de sua vida - tem por si mesmo uma imperiosa necessidade de homogeneidade lógica”.
} 
produzida pela ideologia que o interpela, trabalhando o efeito de evidência dos sentidos e dos sujeitos que, aliás, nunca são transparentes. Como diz Orlandi (1999, p. 61):

\begin{abstract}
O que se espera do dispositivo do analista é que ela lhe permita trabalhar não numa posição neutra, mas que seja relativizada em face da interpretação: é preciso que ele atravesse o efeito de transparência da linguagem, da literalidade do sentido e da onipotência do sujeito. [...] A construção desse dispositivo resulta na alteração da posição do leitor para o lugar construído pela analista. Lugar em que se mostra a alteridade do cientista, a leitura outra que ele pode produzir. Nesse lugar, ele não reflete mas situa, compreende o movimento da interpretação inscrito no objeto simbólico que é seu alvo. Ele pode então conteplar (teorizar) e expor (descrever) os efeitos da interpretação. Por isso é que dizemos que o analista do discurso, à diferença do hermeneuta, não interpreta, ele trabalha (n)os limites da interpretação. Ele não se coloca fora da história, do simbólico ou da ideologia. Ele se coloca em uma posição deslocada que lhe permite contemplar o processo de produção de sentidos em suas condições.
\end{abstract}

Isso é feito, segundo Orlandi (1999), pela mediação teórica que leva o analista, enquanto contempla o que foi dito pelas pessoas, a pensar. $\mathrm{O}$ uso constante da teoria o permite trabalhar o seu corpus de análise, ou seja, o recorte que fará, uma vez que não se busca a horizontalidade de um objeto que se entende como inesgotável. O que se busca é a exaustividade vertical em profundidade em que os "dados" colhidos não são vistos como meras demonstrações, mas são utilizados para "mostrar como um discurso funciona produzindo (efeitos de) sentidos" (ORLANDI, 1999, p. 63).

O analista, então, parte do texto para mostrar como os discursos funcionam em suas regularidades por meio do interdiscurso que, por sua vez, tem sentido em função das formações ideológicas. É bom lembrar que em todo texto, devido o funcionamento do interdiscurso, encontramos uma heterogeneidade de formações discursivas, "pois ele pode ser atravessado por várias formações discursivas que nele se organizam em função de uma dominante" (ORLANDI, 1999, p. 70).

Há, desta forma, uma multiplicidade de leituras dos discursos, posto que é o recorte feito pelo analista que determina a análise, já que "todo discurso é parte de um processo discursivo mais amplo que recortamos", lembra Orlandi (1999, p. 64). Assim, como Orlandi (1999), não considero as falas dos entrevistados como ponto de partida ou de chegada absoluto, mas como 
um exemplar de como o discurso do management se realiza. Portanto, não procuro "o sentido 'verdadeiro', mas o real do sentido em sua materialidade lingüística e histórica", afirma Orlandi (1999, p. 59).

Tendo esses conceitos da AD na linha francesa em mente e, assim, buscando compreender o que não é evidente nas falas dos participantes da pesquisa, ou seja, os sentidos de suas palavras, que construí o dispositivo analítico desta tese, conforme segue:

\begin{tabular}{|l|l|l|r|}
\hline $1^{\text {a Etapa }}$ & Passagem da & Superfície linguistica para o & Texto (discurso) \\
\hline $2^{\text {a Etapa }}$ & Passagem do & Objeto discursivo para o & Formação Discursiva \\
\hline $3^{\text {a Etapa }}$ & & Processo discursivo & Formação ideológica \\
\hline
\end{tabular}

Quadro 3 - Etapas da Análise do Discurso

Fonte - Orlandi (1999, p. 77).

Para chegar à formação ideológica é necessário desvelar as formações discursivas que estão nos discursos produzidos por meio das palavras faladas, escritas ou representadas em imagens. Inicialmente, o corpus bruto - as entrevistas transcritas, os documentos e as imagens - passaram pelo processo de de-superficialização, ou seja, foi convertido em objeto discursivo em que a relação palavras e coisas é desnaturalizada. De forma ainda inicial, procurei ver nos textos sua discursividade $\mathrm{e}$, por isso, dei atenção à paráfrase ${ }^{10} \mathrm{e}$ à polissemia ${ }^{11}$, enfim, ao que foi dito em relação ao que não foi dito devido à memória discursiva (interdiscurso e dialogismo).

Em seguida, já com o objeto discursivo em mãos, seguindo o modelo de Orlandi (1999, p. 67), procurei “observar o modo de construção, a estruturação, o modo de circulação e dos diferentes gestos de leitura que constituem os sentidos do texto". É aqui que busquei os significados produzidos pelos discursos que permitiam ao sujeito se significar dentro de diferentes formações discursivas e, portanto, a análise das paráfrases se acentua, ao mesmo

\footnotetext{
10 “Os processos parafrásticos são aqueles pelos quais em todo dizer há sempre algo que se mantém, isto é, o dizível, a memória. A paráfrase representa assim o retorno aos mesmos espaços do dizer. Produzem-se diferentes formulações do mesmo dizer sedimentado. A paráfrase está ao lado da estabilização" (ORLANDI, 1999, p. 36). 11 "Na polissemia, o que temos é deslocamento, ruptura de processos de significação. Ela joga com o equívoco" (ORLANDI, 1999, p. 36).
} 
tempo em que comecei a observar os movimentos metafóricos, os deslizes nos sentidos das palavras para que o discurso faça sentido.

Por fim, como as formações discursivas estão necessariamente ligadas às formações ideológicas, fui atrás dessas relações. Para Brandão (2004, p. 47):

\begin{abstract}
A formação ideológica tem necessariamente como um de seus componentes uma ou várias formações discursivas interligadas. Isso significa que os discursos são governados por formações ideológicas. São as formações discursivas que, em uma formação ideológica específica e levando em conta uma relação de classe, determinam "o que pode e deve ser dito" a partir de uma posição dada em uma conjuntura dada.
\end{abstract}

Nestas duas últimas etapas, relacionei teoria e discursos para compreender os sentidos das formações discursivas e, consequentemente, das formações ideológicas, num movimento constante de interpretação em que as condições de produção do discurso orientavam minha análise e, por isso, mantive algumas questões orientadoras: ${ }^{i)}$ Qual a relação entre o que foi dito com o não dito? ${ }^{\text {ii) }}$ Quais os efeitos de sentido o sujeito atribui às suas falas - consciente $\mathrm{e}$

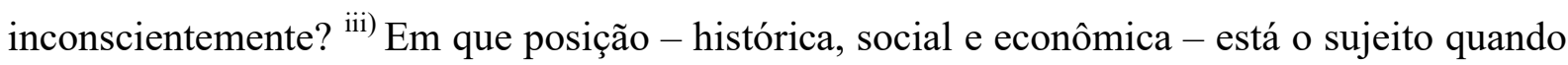
ele fala? ${ }^{\text {iv) }}$ Qual a relação entre seu discurso e os outros produzidos no meio social?

Para Souza e Carrieri (2014, p. 25), “quem o indivíduo é está relacionado à forma como ele fala, escreve e aparenta ser”. As suas estratégias de enunciação estão relacionadas, portanto, àquilo que ele considera verdadeiro e não, desejável e indesejável, válido e não válido, representando a relacionamento entre o que anuncia com suas próprias representações. É desta forma que a Análise do Discurso permite que os discursos sejam acessados, o que fornece uma visão, mesmo que incompleta e até distorcida, da realidade social dos indivíduos, vista aqui como constituída pelos sentidos dos discursos. 


\section{MANAGEMENT E O PROJETO DE CONTROLE DO MUNDO}

O triunfo do capitalismo forçou grande parte do mundo a uma nova configuração social, o que tornou o management ideologicamente hegemônico. A partir de um plano bem concebido porque não se trata de uma modificação que surgiu do arranjo natural da sociedade sustentado nos pilares do management, as pessoas passaram a pensar suas vidas a partir de uma lógica econômica capitalista, em termos de custos e benefícios, desempenho e planejamento.

A lógica econômica capitalista, então, se consubstancia no management, embutindo um projeto universalista, sendo justificada a ideia de não há outra saída, ao mesmo tempo em que manipula o desejo de sucesso pessoal. Desta forma, o management não é só um corpo de técnicas utilizado para gerar resultados, mas também, e principalmente, uma ideologia e, portanto, um mecanismo de poder, afirmam Costa, Barros e Saraiva (2014). E tal ideologia é disseminada por um aparato complexo que conta com a mídia de negócios, as escolas de Administração, as empresas de consultoria e os gurus de gestão, tornando a racionalidade instrumental natural, inclusive necessária para o bem-estar individual e coletivo.

Neste contexto, o objetivo neste capítulo é discutir a atuação ideológica do management visando moldar a sociedade conforme uma lógica econômica capitalista, dificultando qualquer reação contrária aos seus planos. Desta forma, discuto a formação desta hegemonia a partir da reconfiguração social que se dá com o triunfo da ideologia capitalista em grande parte do mundo e, por fim, a generalização do management por meio dos seus pilares para todas as instâncias da vida.

\subsection{O projeto orquestrado: hegemonia e generalização do management}

A maior parte da história mundial se sustentou sobre uma sociedade agrícola, de caçadores e coletores, na qual a esfera econômica não estava separada das outras esferas da sociedade (CHANLAT, 2006). Apesar de o mercado poder ser encontrado neste período histórico, ele nunca foi determinante para a economia - tendo somente importância periférica desde a idade 
da pedra $^{12}$-, como se tornou a partir do século XIX, com a dispersão internacional dos efeitos da Revolução Industrial iniciada na Inglaterra, afirma Polanyi (2000).

As coisas só começaram a mudar após a Revolução Industrial quando, segundo Polanyi (2000), o estabelecimento de uma economia de mercado e, consequentemente, de um credo demasiado de que todas as transações são monetárias, alterou a sociedade.

\begin{abstract}
A transformação implica uma mudança na motivação da ação por parte dos membros da sociedade: a motivação do lucro passa a substituir a motivação da subsistência. Todas as transações se transformam em transações monetárias e estas, por sua vez, exigem que seja introduzido um meio de intercâmbio em cada articulação da vida industrial (POLANYI, 2000, p. 60).
\end{abstract}

Alimentos, roupas e muitos outros produtos que eram feitos em casa e nas pequenas propriedades rurais, para a sobrevivência e manutenção da própria família, passaram a ser produzidos pelo capital industrial. Aos poucos, o mundo se torna um grande mercado, modificando o modo de vida da humanidade de uma forma como nunca antes visto (POLANYI, 2000; BRAVERMAN, 1977). Onde havia a lógica familiar de sobrevivência, passou a vigorar a lógica de mercado: consumo, massificação e racionalização.

Apesar de a Revolução Industrial ter surgido na Inglaterra, foi nos Estados Unidos que a racionalização do trabalho se desenvolveu a partir da revolução gerencial empreendida por engenheiros norte-americanos (SHENHAV, 2002), entre eles Frederick W. Taylor, que desenvolveu um conjunto de técnicas baseado em um modo de pensar que dá respaldo ao capitalismo. Mais do que a sistematização do trabalho, as ideias de Taylor são "a explícita verbalização do modo capitalista de produção", afirma Braverman (1977, p. 83), uma vez que ao dissociar a concepção da realização, o trabalho passa a ser dependente do capital, ou seja, daquele que pode arcar com ele.

\footnotetext{
${ }^{12} \mathrm{Na}$ verdade, todos os sistemas econômicos anteriores à Revolução Industrial, mesmo no período grecoromano, eram organizados com base na "reciprocidade ou redistribuição, ou domesticidade, ou alguma combinação dos três" (POLANYI, 2000, p. 75). O princípio da reciprocidade nas comunidades tradicionais atua sobre o comportamento recíproco, ou seja, se hoje eu dou algo para outro membro da comunidade, amanhã receberei algo em troca. O princípio da redistribuição era uma forma mais generalizada de reciprocidade, uma vez que "os bens eram coletados de forma centralizada e depois distribuídos entre os membros da comunidade, numa grande variedade de formas", explica Polanyi (2000, p. 312). Por fim, o princípio da domesticidade se assenta na produção para uso próprio. As motivações individuais passavam bem longe do lucro, pois estavam ligadas aos princípios gerais de comportamento de suas sociedades, baseadas nos costumes, na religião, nas leis ou no sobrenatural.
} 
O modelo taylorista está sob o ideal de racionalização, uma vez que tudo pode ser pensado por meio de variáveis matemáticas, inclusive o ser humano, transformado no fictício homo economicus, indivíduo sobre o qual "pode-se prever [o] comportamento, otimizar suas escolhas, submetê-lo ao cálculo e traduzir sua existência nos programas", assinala Gaulejac (2006, p. 416).

Os princípios da Administração Científica de Taylor ganharam notoriedade ao redor do mundo, principalmente com a ajuda de organizações civis ou governamentais criadas especialmente para difundir o taylorismo"13, como a Taylor Society, "centro para a constituição de uma importante rede de engenheiros, homens de negócio e cientistas sociais interessados no Management" (FERREIRA, 2008, p. 68).

Tudo andava conforme os planos até que uma revolução socialista irrompeu na Rússia no começo do século $\mathrm{XX}^{14}$. A Revolução Russa, que em sua segunda fase ${ }^{15}$ instalou o socialismo em solo europeu, significou um percalço para os planos internacionais do capitalismo, principalmente pelo "medo da desordem que poderia prejudicar fatalmente a restauração de uma economia de mercado", aponta Polanyi (2000, p. 286).

\footnotetext{
${ }^{13}$ Países europeus, como Inglaterra, França, Alemanha e Suíça, e americanos, como o Canadá e o Brasil, são parte dos esforços de internacionalização do taylorismo e de outras correntes do management. Grupos empresarias também foram importantes no processo de expansão do taylorismo, como as francesas Renault e Citroën, e a americana Westhinghouse, conforme informações de Kipping (1997) e Sasaki (1992) citadas por Ferreira (2008). “A Companhia Mitsubishi [...], logo após sua fundação no início da década de 1920, realiza uma cooperação técnica com a Empresa Americana Westinghouse, no sentido de se ajustar para a produção em massa de componentes elétricos. Deste consórcio, a japonesa Mitsubishi incorporou os métodos de estudo de tempos e movimentos e o sistema de pagamentos da correspondente norte-americana, iniciando um ciclo vigoroso de esforços em direção ao estilo americano de gerenciamento" (SASAKI, 1992 apud FERREIRA, 2008, p. 69).

${ }^{14}$ É sabido que o socialismo também implantou o taylorismo em suas fábricas a partir da ascenção de Stalin ao poder, quando chegou a "definir o bolchevismo como a união do espírito revolucionário russo com o espírito prático norte-americano", lembra Tragtenberg (2007, p. 134). No entanto, enquanto nos países capitalistas o taylorismo servia às classes dominantes e, portanto, para a geração de lucro, no Estado socialista servia ao socialismo, já que se constituía, segundo Lenin e Alexei Gastev, fundador e diretor do Instituto Central do Trabalho soviético, uma parte importante para a transição ao comunismo: eficiência e produtividade (LAZAGNA, 2002).

${ }^{15}$ Segundo Polanyi (2000, p. 289), "aquilo que chamamos Revolução Russa consistiu realmente em duas revoluções separadas, a primeira das quais incorporava ideais europeus ocidentais tradicionais, enquanto a segunda foi parte de um desenvolvimento inteiramente novo da década de 1930. A Revolução de 1917- 1924 foi de fato o último dos levantes políticos da Europa que seguiram o padrão do Commonwealth inglês e da Revolução Francesa. A revolução que começou com a coletivização das fazendas, por volta de 1930, foi a primeira das grandes mudanças sociais que transformaram o nosso mundo na década de 1930. Com a primeira revolução, os russos conseguiram a destruição do absolutismo, do domínio feudal da terra e da opressão racial uma verdadeira herança dos ideais de 1789. A segunda revolução estabeleceu uma economia socialista. Dito isso, a primeira foi apenas um acontecimento russo - ela cumpriu um longo processo de desenvolvimento ocidental em solo russo - enquanto a segunda fez parte de uma transformação universal simultânea".
} 
Assim, por décadas, o mundo viveu uma polarização política e econômica entre o capitalismo e o socialismo soviético, capitaneados pelas grandes potências (econômicas, militares e, principalmente, ideológicas) daquele período, Estados Unidos e União Soviética. Países aliados durante a Segunda Guerra Mundial contra a ameaça nazista que, com o fim do conflito, se distanciaram e se tornaram líderes de mundos oponentes, marcando o cenário geopolítico mundial por cerca de quarenta anos.

No entanto, com a derrubada do sistema socialista na Europa, representada pela queda do Muro de Berlim no final da década de 1980, o capitalismo se tornou o modelo econômico hegemônico ${ }^{16}$, sendo as diferenças "modelos dentro do sistema capitalista" (CHANLAT, 2006, p. 10). Ainda para Chanlat (2006, p. 11), este panorama forçou a maioria das economias mundiais a se encaixar, de uma forma ou de outra, no sistema capitalista, visto que "não há alternativa melhor a curto prazo e as alternativas estão dentro do sistema".

Vimos, com isso, o triunfo da ideologia capitalista para grande parte do mundo - tendo sua variante, o neoliberalismo, alcançado status mundial - levando Francis Fukuyama a afirmar na época que a exaustão do sistema oponente ao liberalismo econômico e a consequente disseminação da cultura consumista ocidental para os países do Leste significava o "fim da história”, etapa final da evolução da humanidade ${ }^{17}$.

Depois desse fato, por não contar mais com um modelo oponente, o sistema capitalista se tornou dominante e fez surgir uma tripla hegemonia: 1) hegemonia da esfera econômica; 2) hegemonia do modelo organizacional da empresa; 3) hegemonia do pensamento administrativo (CHANLAT, 2006). A construção de uma hegemonia exige a superação de

16 Mais do que um projeto político, o socialismo significou um desafio ao modelo ideológico capitalista. Mesmo entre seus críticos, o socialismo sempre foi aceito como um modelo de sistema contrário ao capitalismo (MIGLIOLI, 1995). E como deve ocorrer entre oponentes, era respeitado e estudado. O colapso do mundo soviético, no entanto, extinguiu o oponente.

17 Para aqueles que se alinham às ideias de "fim da história", os exemplos são contundentes. Até mesmo a China, país dirigido por um partido comunista, é hoje um modelo de capitalismo. E a Rússia, centro do poder soviético, se tornou um os maiores mercados de consumo de luxo do mundo Segundo reportagem publicada no site da revista Época: “a descompressão social, aliada à abertura da economia, liberou o ímpeto consumista da população, reprimido durante os tempos do comunismo. De repente, os russos tiveram acesso a todo tipo de bem de consumo - de carrinhos e carrões a queijos e vinhos, de computadores a sandálias havaianas. No princípio, muitas novidades eram desconhecidas na Rússia. A publicidade cumpriu o papel educativo de apresentá-las ao consumidor" (FUCS, 2011, [s/p]). Matéria na mesma linha já havia sido publicada pela revista Veja em 2008, onde é possível ler que a grande concentração de "novos-ricos" possibilitou um crescimento estrondoso do consumo de luxo nos últimos anos em Moscou, capital da Rússia (FAVARO, 2008). 
diferentes modos de pensar e ser por uma ideia única. Portanto, a hegemonia, como uma totalidade, significa que pontos de vista individuais são substituídos pelo consenso.

A hegemonia da esfera econômica se consubstancia na eliminação de qualquer obstáculo, seja humano ou cultural, pela primazia do mercado e sua lógica de expansão mercantil-capitalista (BELLUZZO, 2004). Para isso, é necessário moldar as subjetividades e, portanto, as práticas, pelos critérios econômicos. Para Belluzzo (2004, p. 128):

O consenso dominante trata de explicar que, se não for assim, sua vida pode piorar mais. A formação desse consenso é, em si mesmo, um método eficaz de bloquear o imaginário social, numa comprovação dolorosa de que as criaturas da ação humana coletiva - as instituições produzidas pelo devir histórico - adquirem dinâmicas próprias e passam a constranger a liberdade de homens e mulheres.

Essa primazia impõe que a maior parte das pessoas passe a pensar o mundo a partir de uma lógica econômica capitalista, em termos de custos e benefícios, desempenho e planejamento. Como no imaginário não há nada mais eficiente, efetivo e produtivo do que uma empresa privada (MARTTILA, 2013), seu modelo organizacional e o pensamento administrativo se tornam panaceias dos novos tempos. Tudo deve ser organizado como se fosse uma empresa, da esfera pública à esfera privada. Resultam desse movimento as hegemonias do modelo organizacional da empresa e do pensamento administrativo, apontadas por Chanlat (2006).

Colaboram com essa visão de vida administrada as revistas de negócios, cujas capas vivem povoadas com a imagem dos grandes empresários e gestores mundiais, mostrando histórias de sucesso, de superação e seus conselhos aos neófitos ${ }^{18}$. Muitas vezes, as revistas de negócio se confundem com as de celebridades, se transformando em uma espécie de "Caras ${ }^{19}$ do mundo corporativo". E como uma celebridade, os empresários e gestores das grandes empresas são

\footnotetext{
${ }^{18}$ As revistas são capazes de lançar mitos (e também de derrubá-los) como em um passe de mágica. Um dos casos mais recentes foi do empresário Eike Batista, que foi apresentado pela mídia há cerca de oito anos como uma figura mitológica do mundo corporativo, aquele em que tudo toca vira ouro, um Midas contemporâneo, fazendo referência ao personagem da mitologia grega. Façanha que o tornou o homem mais rico do Brasil e o sétimo mais rico do mundo, segundo o ranking da Forbes de 2012. Em pouco tempo se tornou um heroi, a fonte de inspiração para milhões de pessoas que viam sua trajetória de sucesso como modelo de vida. Se espalham pela mídia notícias sobre suas empresas - todas com nomes terminados com a letra $\mathrm{X}$-, seus feitos, inclusive como patrocinador de projetos sociais e ecológicos e seus gostos - belas mulheres, esportes e brinquedos caros, como carros esportivos e lanchas (LUNA, 2010).

${ }^{19}$ Revista de celebridades brasileira.
} 
idolatrados e se tornam modelos de comportamento, induzindo valores e crenças às outras pessoas (PAULA; WOOD JR., 2002; WOOD JR.; PAULA, 2006).

Desta forma, o management é visto como o meio para o sucesso e, assim, para a felicidade. Nas revistas de negócios, o sucesso profissional carrega o sentido de alto status social, seguido do reconhecimento que esta posição proporciona. No entanto, "reconhecimento e existência sociais não têm outro valor além do monetário. O dinheiro abre todas as portas, elimina todos os obstáculos, permite a concretização de todos os sonhos. Com isso, torna-se o instrumento da realização de si mesmo" (ITUASSU; TONELLI, 2014, p. 101). A imagem que as revistas de negócios desenham daqueles que "progrediram ${ }^{20}$ na vida" por meio do trabalho é justamente de uma pessoa realizada ${ }^{21}$.

Mas será que as promessas de felicidade e realização são suficientes para alguém se assujeitar à ideologia do management? Sim, já que a ideologia não precisa da realidade, pois ela é somente “uma 'representação' da relação imaginária dos indivíduos com suas condições reais de existência”, defende Althusser (1983, p. 85). É por isso que qualquer pessoa, independente das suas condições objetivas, se vê no direito de manter a esperança de alcançar o sucesso garantido aos homens de negócios, uma vez que o que importa não é mundo real, mas a sua relação com suas condições reais de existência. Eagleton (1997, p. 30) cita um trecho de Althusser que explica bem essa ideia: "a ideologia [...] 'expressa uma vontade, uma esperança ou uma nostalgia, mais do que descreve uma realidade"”.

Sobre o conceito althusseriano de ideologia, Prestes Motta (1992, p. 42) explica:

\begin{abstract}
Assim, não se pode simplificar o conceito de ideologia, identificando-a com o simples discurso da classe dominante. A ideologia deve ser encontrada na ação das classes sobre o Estado, a empresa, a escola e todas as instituições modernas. É preciso notar que a ideologia está sempre a serviço de um projeto, que se traduz em uma prática política.
\end{abstract}

A ideologia dominante é a que saiu vitoriosa na luta de classes. Sendo assim, compete a todos os aparelhos ideológicos, a sua maneira, reproduzir as relações de produção próprias do

\footnotetext{
${ }^{20}$ A ideia disseminada pelas revistas de negócios é justamente baseada no evolucionismo.

${ }^{21}$ Ituassu e Tonelli (2014) constatam que nas revistas de negócios pouco se fala dos resultados negativos do sucesso.
} 
vitorioso. Neste caso, da ideologia capitalista. E isso é feito por meio do aparelho político, do aparelho de informação (mídia), do aparelho cultural, do aparelho religioso, do aparelho familiar e, principalmente, do aparelho escolar, que dissemina as ideias dos dominantes, submetendo a todos à ideologia política capitalista (ALTHUSSER, 1983).

O problema da visão estruturalista de Althusser (1983) é seu caráter monolítico, sendo a disseminação da ideologia da classe dominante exclusivamente planejada e imposta pelo Estado. Para Guattari e Rolnik (1996), o campo social como um todo participa do processo de produção de subjetividades, responsável pelo registro das ideologias, uma vez que definem as formas como o sujeito irá perceber o mundo. "Trata-se de sistemas de conexão direta entre as grandes máquinas produtivas, as grandes máquinas de controle social e as instâncias psíquicas que definem a maneira de perceber o mundo", afirmam Guattari e Rolnik (1996, p. 27). A subjetividade, portanto, é construída no corpo social por meio de uma multiplicidade de agenciamentos sociais. Como resultado disso, "a subjetividade não se situa no campo individual, seu campo é o de todos os processos de produção social e material" (GUATTARI; ROLNIK, 1996, p. 32).

É assim que a produção da subjetividade coletiva se torna matéria-prima, uma vez que modela os comportamentos, a memória, a percepção, as relações humanas, entre outras instâncias da vida, propiciando o registro das ideologias, conforme defendem Guattari e Rolnik (1996). A ideologia capitalista se torna objeto de desejo quando os processos de subjetividade foram trabalhados, visto que "sem um trabalho de formação prévia das forças produtivas e das formas de consumo, sem um trabalho de todos os meios de semiotização, econômica, comercial, industrial, as realidades sociais locais não poderão ser controladas" (GUATTARI; ROLNIK, 1996, p. 28).

Neste contexto, ganha força no imaginário social a "cultura do management", conceituada por Wood Jr. e Paula (2006, p. 94) como:

Um conjunto complexo de códigos e padrões que regulam a ação humana individual e coletiva e que se manifestam em todos os aspectos da vida: modos de sobrevivência, normas de comportamento, crenças, instituições, criações materiais, entre outros. 
Códigos e padrões formados a partir de uma lógica econômica e administrativa que, ao invés de ficarem restritos à esfera em que foram criados, a ultrapassam, de forma que passa a constituir todas as instâncias da vida social. Não se trata, portanto, do fruto das relações sociais, mas de um modo de pensar criado na esfera corporativa e que, progressivamente, moldou as nossas vidas (ITUASSU; TONELLI, 2014). Para Costa, Barros e Saraiva (2014, p. 2), o management naturaliza o modelo organizacional, suas estratégias, práticas e ideologia, para toda a sociedade, justificando "toda e qualquer ação sob uma lógica econômica que é maior e mais forte que cada um de nós e não um produto de nossa sociedade".

Para Adorno e Horkheimer (1999), a massa da população aceita como necessário e natural administrar e ser administrado, como uma praxis brutal da sobrevivência. "Seu rebaixamento a meros objetos da Administração, que enforma antecipadamente cada setor da vida moderna, até mesmo a linguagem e a percepção, prega-lhes a peça da necessidade objetiva, contra a qual eles crêem nada poder fazer" (ADORNO; HORKHEIMER, 1999, p. 57). É assim que palavras costumeiramente utilizadas nas relações comerciais foram incorporadas ao dia a dia das pessoas. De políticos a donas de casa, qualquer um fala em gestão: "gestão da saúde”, “gestão das emoções", "gestão do tempo", "gestão dos relacionamentos".

O management pode ser entendido como um corpo de técnicas utilizado para gerar resultados, mas também, e principalmente, como uma ideologia e, portanto, um mecanismo de poder, afirmam Costa, Barros e Saraiva (2014). De fato, o modelo organizacional tornou-se um modelo de vida. Nada mais natural quando a vida é comparada ao capital - "o capital mais precioso" - e, portanto, aos negócios, já que "a vida é business", como critica Gorz (2005, p. 24). Wood Jr. e Paula (2006, p. 100) apontam, no seu estudo sobre a mídia de negócios, a profusão de palavras-chave simbólicas, como "você S/A", também título de uma importante revista do meio empresarial, que levam o indivíduo à necessidade de "se tornar uma marca de sucesso". Esse discurso liberta a produção de si mesma e dos constrangimentos que carrega, pois subordina qualquer atividade humana à lógica capitalista.

A ideologia generalizada do management está na aplicação do gerencialismo, ou seja, “a colonização de vários domínios pelo discurso da gerenciabilidade”, esclarecem Ituassu e Tonelli (2014, p. 88). Como consequência disso, o modelo de organização, mesmo no setor 
público, torna-se o das empresas privadas, visto que há hegemonia do pensamento administrativo $^{22}$.

A aplicação de técnicas do setor privado é o sintoma de um problema maior: a coordenação do Estado pelo mercado. Mercado, que é uma construção política, viabilizado pelo Estado, que, ao mesmo tempo, como parte das relações sociais, é institucionalizado pelo mercado, constata Reis (2011). Há, portanto, uma via de mão dupla nesta relação. Uma vez que o Estado tem o papel de estabelecer consensos e fixar significados por meio do "seu papel na estruturação dos comportamentos dos atores sociais e das relações que estes estabelecem”, o mercado precisa dele, não só pelo seu poder com as questões econômicas, mas, principalmente, pela sua capacidade de definir contextos de ação e formas de comportamento (REIS, 2011, p. 22).

O management está estruturado como uma indústria ${ }^{23}$, tendo como seus pilares a mídia de negócios, as escolas de Administração, as empresas de consultoria e os gurus de gestão. $\mathrm{O}$ fenômeno, de tão amplo, saiu do escopo de Administração como prática e como campo de conhecimento, tornando-se "um setor de negócios: uma indústria emergente e bem sucedida" (WOOD JR; PAULA, 2006, p. 104). Cada um desses pilares se interrelacionam, contribuindo para disseminar e reforçar a ideologia do management, de forma que ela se torne natural aos olhos de todos, dentro e fora das organizações.

\footnotetext{
22 O próprio Estado incorpora, impulsionado por agências multilaterais como o Banco Mundial e o Fundo Monetário Internacional (FMI), o modelo de gestão das empresas privadas, pensando em termos de performance, eficiência, eficácia, flexibilização e terceirização. Os critérios para a eficiência e a eficácia são os mais problemáticos pois o Estado não pode pensar somente em termos econômicos. Para Chanlat (2006), "não é fácil avaliar realmente o que é a eficácia de um sistema [visto que] há seguramente exigências financeiras, mas há também exigências sociais". Um hospital público não pode se ater somente às exigências financeiras enquanto seu objetivo é salvar vidas. A mesma coisa pode ser dito das escolas e universidades. Para Vainer (2000), nos últimos anos, até as cidades passaram a ser vistas como produto e empresa e, como tal, foram apropriadas pelos interesses econômicos. Como produto, as cidades são mercadorias de luxo a serem vendidas. Para isso, precisam conter atributos valorizados pelo capital para serem atraentes. Como empresa, as cidades devem ser geridas estrategicamente como uma empresa privada para que tenham produtividade e sejam "competitivas" umas perante as outras. Sendo assim, chega-se a uma lógica implacável: "a melhor solução, aqui como em outras situações similares, é recorrer a quem entende do métier - se de empresa se trata, convoquem-se os empresários; se o assunto é business, melhor deixá-lo nas mãos de businessmen", conclui ironicamemente Vainer (2000, p. 87, grifo do autor).

${ }^{23}$ Gatti (2008, p. 77) lembra que para Adorno "o termo indústria refere-se, sobretudo, à racionalização dos procedimentos de planejamento e à consequente padronização do produto". Ou seja, da antecipação das regras que orientam o produto final, inclusive com a determinação das técnicas de divulgação e das tendências, que levam a padronização dos produtos. Adorno fez uso deste conceito de indústria na análise sobre os produtos culturais, mas o conceito pode ser expandido a outras indústrias, uma vez que o contexto que sustenta a indústria cultural é o mesmo das demais, o capitalismo administrado.
} 
O papel da mídia de negócios é bastante importante nesse processo, uma vez que, pela sua popularização, chega mais rapidamente aos lugares mais distantes. Por meio de revistas, livros e jornais populares de gestão, e mais recentemente, pela disseminação dos programas de negócios na televisão ${ }^{24}$, o ideário do management alcança repercussão social, ajudando a construir uma visão específica de mundo. Esse é o resultado de pesquisas sobre a mídia de negócios no Brasil feitas por Donadone (2000), Paula e Wood Jr. (2002), Wood Jr e Paula (2006; 2008), Carvalho, Carvalho e Bezerra (2010) e Ituassu e Tonelli (2014), na Itália por Mazza e Alvarez (2000), e na França por Boltanski e Chiapello (2009).

Se inicialmente a mídia de negócios se ocupava basicamente em apresentar informações econômicas aos seus leitores, nos últimos tempos ela se preocupa em influenciar na formação da opinião pública. Os pensadores da Escola de Frankfurt, em especial Theodor Adorno e Max Horkheimer, dedicaram bastante tempo à formação da opinião pública e, ainda na década de 1940, afirmaram que o sistema de dominação da consciência humana exercido pelo capital funciona principalmente pelos mecanismos de controle da indústria cultura, ou seja, imprensa, cinema e rádio que cuidam de incorporar as pessoas à ideologia do sistema por meio da promessa de felicidade - nem sempre alcançada (GATTI, 2008).

Outro representante da Escola de Frankfurt a tratar do tema é Marcuse (1975), que enfoca o poder dos monopólios de comunicação sobre a construção da subjetividade. Para ele, esses grandes conglomerados midiáticos tomaram para si a missão de educar toda uma sociedade, reprimindo qualquer instinto individual, este considerado como um comportamento desviante. Para tanto, impuseram padrões de conduta que se tornaram mais fortes do que os definidos pelas famílias na formação dos sujeitos.

A concepção de uma mídia integrada ao sistema econômico dominante também foi desenvolvida por Herman e Chomsky (2002), para os quais, a partir da década de 1990, com a

\footnotetext{
${ }^{24}$ São exemplos de programas de TV com cunho empresarial no Brasil: Pequenas Empresas, Grandes Negócios, da TV Globo; Mundo S/A e Conta Corrente da Globonews; e o Show Business da TV Bandeirantes, programas nos quais é comum assistir entrevistas com empresários de sucesso e com os consultores mais badalados. Mesmo em um programa como o Conta Corrente, voltado as questões econômicas, grandes blocos são dedicados a matérias sobre o perfil dos trabalhadores mais disputados pelas empresas, sucesso profissional, carreiras da moda, entre outros.
} 
globalização econômica, a concentração no $\operatorname{setor}^{25}$ e a sua expansão para as mais diversas economias, disseminou os interesses das grandes empresas dos países avançados e a ideologia de mercado pelo mundo. Se antes a ação desses grupos de mídia, apesar de bastante forte, era localizada, agora passam a modelar quase todas as sociedades conforme as necessidades e desejos desses conglomerados.

Não é por acaso que o modelo seguido pela mídia de negócios no Brasil é o das revistas e jornais norte-americanos. Donadone (2000) lembra que os dois primeiros veículos da imprensa de negócios neste modelo importado são a revista Exame, criada em 1971, e o jornal Gazeta Mercantil, de 1977. As revistas norte-americanas Business Week e Fortune são modelos editoriais e fonte de matérias da revista Exame; e o jornal Gazeta Mercantil se inspira nos jornais The Wall Street Journal e Financial Times. Desta forma, se desenvolvem de forma bastante íntima com os veículos do norte do continente. Não que isso seja exclusivo do mercado brasileiro. Como uma economia dominante, os Estados Unidos levaram seu modelo para diversas economias, como a francesa, onde os executivos desejavam, como questão de sobrevivência, se tornar tão eficientes quanto os seus pares norte-americanos (BOLTANSKI; CHIAPELLO, 2009).

Sendo assim, a mídia de negócios brasileira, de mero expositor de boletins econômicos, passa a prescrever formas de gestão mais eficientes para os executivos ${ }^{26}$. Isso muda a forma como as publicações de negócios se relacionam com seus leitores. A ideia agora não é mais apenas apresentar informações econômicas, mas como no caso da revista Exame,

Fornecer análises da forma como as mudanças na economia afetariam as indústrias, [...] divulgar as "novidades" tecnológicas e organizacionais implementadas pelas empresas na tentativa de superar a crise financeira, procurando alimentar o crescente

\footnotetext{
${ }^{25}$ Herman e Chomsky (2002), citando a observação de Ben Bagdikian sobre as edições de sua obra Media Monopoly, chamam a atenção para a grande concentração nos conglomerados de mídia nos Estados Unidos. Em 1983, quando foi publicada a primeira edição do seu livro, Bagdikian encontrou "cinquenta grandes empresas dominando quase toda a mídia de massa; mas, somente sete anos depois, em 1990, somente vinte e três empresas ocupavam a mesma posição dominante" (HERMAN; CHOMSKY, 2002, p. xiii). A concentração de mercado se deu também entre nove transnacionais de mídia - Disney, AOL Time Warner, Viacom (controladora da CBS), News Corporation, Bertelsmann, General Electric (controladora da NBC), Sony, AT\&T-Liberty Media e Vivendi Universal -, gigantes que possuem também estúdios de filme, redes de TV aberta e por assinatura, gravadoras, portais na internet e editoras.

${ }^{26}$ No Brasil, a mídia de negócios surgiu na década de 1960 e se caracterizava basicamente por apresentar boletins econômicos dos diversos setores e debates sobre a economia nacional. Na década seguinte, os leitores não se contentam mais só com os dados macroeconômicos e passam "a buscar maiores informações sobre o modo como os acontecimentos econômicos afetariam as empresas e suas aplicações financeiras", aponta Donadone (2000, p. 3).
} 
interesse dos empresários e gerentes por formas de gestão que garantissem a sobrevivência das empresas frente às dificuldades da economia (DONADONE, 2000, p. 4).

Isso não quer dizer que essas revistas se apoiem fielmente nos fatos e na consistência analítica. Para Boltanski e Chiapello (2009) a literatura de negócios pode ser lida em dois planos: 1) como recomendações técnicas que promete uma gestão mais eficiente e melhoria da competitividade das empresas; 2) como uma fonte moral, que diz aquilo que deve ser, não ao que é de verdade. É justamente dessa forma prescritiva que a literatura de negócios trabalha na construção de representações mentais do espírito do capitalismo, ou seja, da "ideologia que justifica o engajamento no capitalismo" (BOLTANSKI; CHIAPELLO, 2009, p. 39). Desta forma, a literatura de negócios funciona como um legitimador, justificando e sustentando a ordem dominante.

Assim, há uma "grande homogeneidade nos discursos e, para cada época considerada, uma organização geral em torno de um número limitado de temas" nos textos publicados na mídia de negócios, afirmam Boltanski e Chiapello (2009, p. 86). Para eles, essa é uma forma eficaz de disseminar a ideologia do management, uma vez que as ideias são moduladas por meio da repetição. Assim, traduzem-se temas, que passam de um veículo ao outro com rapidez - dos jornais, as revistas, ao rádio, a televisão e a internet - sendo que "suas diferenças, frequentemente mínimas, têm o resultado de oferecer a diversos atores pontos de apoio diferentes para que eles possam captar as orientações que se busca transmitir e com elas se identificar" (BOLTANSKI; CHIAPELLO, 2009, p. 87).

Seu compromisso maior, portanto, está na disseminação da ideologia do management. E assim, o conteúdo disseminado por elas, invariavelmente, “é caracterizado por uma visão utilitarista do mundo, com pontos de vista homogêneos sobre a economia, sobre as empresas e sobre os indivíduos" (WOOD JR; PAULA, 2008, p. 195, tradução minha). Nesta visão específica, vivemos em uma sociedade tecnológica global em constante mudança, cercados por empresas flexíveis e orientadas pelos desejos e satisfações dos clientes, onde as pessoas devem gerir suas vidas e carreiras como se marcas fossem.

Na mídia de negócios não há preocupação com longevidade das suas prescrições, pois sempre há uma novidade a ser criada para a próxima edição visto que "revistas e jornais estão nas 
mesas dos executivos a cada dia", lembram Mazza e Alvarez (2000, p. 581, tradução minha). É desta forma que as revistas de negócio e a "literatura administrativa de mercado", nas palavras de Mattos (2003), se tornaram especialistas em pop-management, "versão 'divertida' da literatura do management que lhe apoia na popularização", afirma Paula e Wood Jr. (2002, p. 5).

As novidades gerenciais desenvolvidas nos ambientes corporativos nos Estados Unidos são apresentadas numa linguagem de fácil entendimento, na forma de pacotes prontos. "Com isso, a Administração, tal qual a indústria da moda, se sujeita a estações, e é importante para a inserção no mercado saber se o modelo atual é o que está 'quente', sob pena de se parecer ultrapassado", constata Saraiva (2011, p. 9, grifo do autor). Neste modelo, não há espaço para visões críticas e discussões teóricas, que não podem ser moldadas na forma de receita milagrosa, homogêneas e padronizadas ${ }^{27}$ (WOOD JR; PAULA, 2008).

A lógica da literatura popular de negócios, segundo Mattos (2003), é justamente desdenhar das bases racionais do conhecimento científico propostas por Popper, de que para se fazer ciência torna-se necessário questionar o senso comum. Isso porque esse tipo de literatura utiliza a mesma lógica do senso comum, a indução ${ }^{28}$ : “"se foi, será; se funcionou, funcionará' [,] ou [até,] 'se funciona assim, é porque é assim'” (MATTOS, 2003, p. 62). Na falta de argumentos lógicos, lançam mão de narrativas exuberantes, de generalizações e de conceitos vagos, sempre tão sedutores ${ }^{29}$.

Se os gurus do management são impulsionados pela mídia de negócios, são eles que, em contrapartida, ajudam a legitimar este veículo "como porta voz, no mercado de divulgação de

27 Um dos exemplos disso é o livro lançado pelo empresário brasileiro, Ricardo Semler, Virando a Própria Mesa, na década de 1980, que virou um best seller nacional. Descrevendo a experiência do autor na indústria que havia herdado do pai, a obra de Semler tem, segundo Donadone (2000), a mais importante característica das publicações de negócios de sucesso: prescreve um "remédio" para curar as empresas "doentes". "Isso ficava claro na abertura do livro, quando era apresentada uma Bula, em que se procurava mostrar o modo de usar, as indicações (para a hipertensão administral e hipertrofia organizacional) e Posologia (para adultos em cargos de direção)", descreve Donadone (2000, p. 13, grifos do autor).

28 Alguns poderiam dizer que se trata do critério de verificação empírica, ou seja, do confronto entre fatos supostamente relativos que, a cada vez que se obtêm os mesmos resultados, constata-se a realidade. "Mas não é assim. O 'novo' fato observado é apenas mais uma observação; a relação positiva dele com a expectativa anterior não está nele próprio, mas corre por conta, justamente, da lógica da indução. [...] A verificação positiva, ou simplesmente a verificação, é crença inabalável do senso comum”, esclarece Mattos (2003, p. 62).

29 Para Moura (2014, p. 64) a fragilidade conceitual na Administração não se restringe à literatura popular de negócios, já que os manuais de introdução às teorias da administração mais utilizados nos cursos de graduação em Administração no Brasil disseminam conceitos vagos, simplistas e hipergeneralizados que não são simples expressões linguísticas, mas, sobretudo, "ocultam importantes dimensões sociopolíticas e, por isso, trazem consigo certo efeito ideológico". 
'novidades organizacionais' possibilitando 'novos vôos"”, afirma Donadone (2000, p. 14). Daí as revistas de negócios manterem uma forte ligação com os gurus do management, publicando seus artigos, indicando seus livros, enfim, tornando-os celebridades. Autores que, se não podem ser chamados de charlatães, no mínimo possuem sérias deficiências em sua formação em Administração, quando não têm nenhuma formação na área, criticam Carvalho, Carvalho e Bezerra (2010). E que, devido às carências de conhecimento de seus autores, produzem uma literatura simplista, impositiva, abusando da estrutura binária entre o moderno e o antiquado, o bom e o ruim (CARVALHO; CARVALHO; BEZERRA, 2010; WOOD JR.; PAULA, 2006). Os maiores sucessos editoriais deste segmento, aliás, apontam Carvalho, Carvalho e Bezerra (2010), recorrem à fantasia encontrada nos livros esotéricos.

Por serem leituras fáceis, acessíveis e que, ainda, prometem milagres, viram uma verdadeira febre. Muitos consultores, por exemplo, em busca de novidades gerenciais, percorrem as prateleiras das livrarias, ávidos pelos lançamentos mais recentes que poderão dar-lhes subsídios, das conversas de bar ao seu trabalho diário. As empresas de consultoria, aliás, são um dos pilares do management, uma vez que "os negócios das empresas de consultoria experimentam intensa convergência e sinergia com as novidades divulgadas nos cursos de Administração e também disseminadas pela literatura de pop-management", afirmam Paula e Wood Jr. (2002, p. 7). A cada modismo lançado pelos gurus ${ }^{30}$, amplamente divulgado pelas revistas de negócios e por meio de livros de pop-management, sacia-se a sede dessas empresas e de seus profissionais por um novo "produto".

Costa, Barros e Saraiva (2014) lembram que o management, como uma indústria, além de um campo de conhecimento e de uma ideologia, é também um produto, pronto para ser vendido. E se tornou nos últimos anos um produto bastante valioso, capaz de aumentar consideravelmente os ganhos do setor editorial, ao mesmo tempo em que as técnicas de gestão, instrumentos que prometem "soluções sob medida à geração de resultados nas organizações", se prestam a instrumentalidade das empresas de consultoria (COSTA; BARROS; SARAIVA, 2014, p. 1).

\footnotetext{
${ }^{30}$ A literatura de negócios também é amplamente adotada por professores dos cursos de Administração, que acabam por oferecer aos seus alunos "informações de qualidade duvidosa apoiando-se na literatura de popmanagement", acusam Paula e Wood Jr. (2002, p. 6). A disseminação deste tipo de literatura se torna tão trivial que, conforme estudo de Carvalho, Carvalho e Bezerra (2010), os alunos de Administração são incapazes de distingui-las dos livros esotéricos e de autoajuda, visto que a proposta de todos eles é o mesmo: ajudar o ser humano no caminho da felicidade.
} 
No management, a educação se dá principalmente nas escolas de negócios, em cursos de graduação e pós-graduação. Estamos falando de um poder extraordinário ${ }^{31}$, tendo em vista "o crescimento exponencial de cursos de Administração [que] transformou esta área na locomotiva da educação superior brasileira”, informa Saraiva (2011, p. 2), baseado nos dados divulgados em 2009 e 2010 pelo INEP, Instituto Nacional de Estudos e Pesquisas Educacionais Anísio Teixeira, do governo federal.

Nos últimos anos, houve também uma ampliação significativa na quantidade de cursos de pós-graduação em Administração, o que, para Laufer (2006), tem relação com a importância que as empresas passam a ter nas sociedades contemporâneas. Nesse quadro, são formados anualmente milhares de graduados em Administração e outros tantos pós-graduados lato sensu e stricto sensu nas linhas correlatas a este campo, oriundos das mais diversas áreas do conhecimento.

No entanto, para Aktouf (2005, p. 151), o grande problema do ensino de Administração está no conservadorismo ${ }^{32}$ que faz com que, mesmo por trás do discurso de mudança, tende-se a reproduzir "os mesmo modelos, os mesmos modos de pensar". E, pior, modelos e modos de pensar doutrinários ${ }^{33} \mathrm{e}$, portanto, ideológicos, oriundos dos grandes dirigentes, largamente adotados nas escolas de gestão, continua Aktouf (2005).

Para Tragtenberg (2005, p. 226), no management a ideia é "prever a mudança e antecipá-la para que nada mude muito". Para isso, criou um corpo de conhecimento que legitima o capitalismo e esconde a exploração do trabalho "necessárias à reprodução ampliada do capital" (TRAGTENBERG, 2005, p. 231). Sob o rótulo de "empresa como "função social"”, esconde as estratégias que surgiram para subjugar o trabalhador aos ditames do mercado, das técnicas de relações humanas que negavam o conflito (PRESTES MOTTA; VASCONCELOS, 2006) até as mais atuais de "cogestão" e "participação". Todas elas estão a

\footnotetext{
${ }^{31}$ A expansão dos cursos de graduação em Administração no Brasil foi tão expressiva que resultou na posição de número um entre os cursos superiores com mais estudantes, conforme último levantamento divulgado pelo INEP (MATSUKI, 2013).

32 Nos cursos de pós-graduação é bastante comum encontrar, além dos graduados em Administração, dentistas, bacharéis em direito, médicos, psicólogos, economistas, pedagogos, veterinários, engenheiros, entre outros. Isso não é necessariamente ruim. Na verdade, conforme defende Aktouf (2005), são as pessoas que vem de outras áreas do conhecimento que farão a Administração avançar. No entanto, na prática, muitas vezes, o saber dessas pessoas é ignorado e elas se tornam mais uma peça na engrenagem a reproduzir a ideologia do management, devido o conservadorismo presente nas escolas de gestão.

33 Aktouf (2005, p. 152) nos lembra que "no começo do século [XX], Henry Fayol descreveu a administração como uma doutrina".
} 
serviço da ideologia do management a partir do momento em que têm como único objetivo "a paz social, a harmonia social e a mutação da sociedade por meio da empresa", argumenta Tragtenberg (2005, p. 227).

Para Gaulejac (2006, p. 426), “as matérias lecionadas sob o termo 'gestão' não ajudam a pensar". Gaulejac (2006, p. 426) constata isso quando enxerga as disciplinas dos cursos de Administração como simplesmente um amontoado de técnicas que tem como objetivo "modelar a gestão do homem", transformando sua "realidade com base em objetivos de produção". Ao alinhar as disciplinas do curso ao funcionamento, puro e simples, dos setores das organizações, reproduz o modelo da empresa capitalista ocidental ${ }^{34}$, dirigida por homens brancos e heterossexuais (SARAIVA, 2011). Aquilo que não se encaixa nesse estereótipo é ignorado, apesar da diversidade da população e variedade das organizações brasileiras. Como resultado disso, as escolas de gestão têm formado "clones" (AKTOUF, 2005), meros espectadores, ao invés de seres humanos reflexivos (SARAIVA, 2011; KOPELKE; BOEIRA, 2014).

\begin{abstract}
Nesse contexto, a reflexividade é considerada ruim, pois tem um potencial contestador e perturbador da ordem funcionalista. A emancipação passa a ser vista como uma ameaça ao status quo empresarial. A ideologia gerencialista favorece uma visão de mundo na qual o ser humano é tratado como recurso a serviço da empresa, e o questionamento desta lógica pode ser perversa para os fins utilitaristas da organização (KOPELKE; BOEIRA, 2014, p. 3, grifo dos autores).
\end{abstract}

Ressalta Althusser (1983, p. 58) que, para a reprodução da força de trabalho, as escolas asseguram o "conhecimento útil" ao sistema, "conforme o posto que [o sujeito] esteja ‘destinado' a ocupar”. Este “conhecimento útil” é formado por técnicas e conhecimentos necessários ao trabalho, mas, principalmente, pelas regras de bom comportamento, "regras de respeito à divisão social-técnica do trabalho e, em definitivo, regras da ordem estabelecida pela dominação de classe" (ALTHUSSER, 1983, p. 58).

\footnotetext{
${ }^{34}$ Nos últimos anos têm se espalhado a ideia de que não basta estar na sala de aula para se aprender gestão. É preciso praticar, uma vez que como solucionador de problemas da sociedade, nas palavras de Schön (1983), o administrador desenvolve suas habilidades em contato direito com as organizações. Pensando assim, muitas universidades têm criado empresas juniores. Em uma visão ingênua, as empresas juniores são vistas como importantes coadjuvantes no contexto pedagógico por promover, em um ambiente real, habilidades necessárias ao profissional de negócios (LOPES; LOPES; LIMA, 2007), elevando "o nível de competência da população universitária" (LAFEUILLE, 1997, p. 15). Visão criticada por Bicalho e Paula (2012, p. 909), para as quais as empresas juniores são locus de reprodução da "realidade vigente no contexto socioeconômico" e que, por isso, ao invés de promover questionamentos sobre o status quo, acaba por reforçar a ideologia do management.
} 
Em resumo, de acordo com Althusser (1983, p. 58), aprende-se na escola a "submissão às normas da ordem vigente", visto que a reprodução das relações de produção se assegura pela hegemonia ideológica. Hegemonia que não nasceu na escola, mas que é por ela disseminada, pois é nela, principalmente, que é aprendida e reforçada e, assim, reproduzida em qualquer esfera da vida social. É por isso que, para Althusser (1983), entre todos os aparelhos Ideológicos, nenhum é tão eficaz quanto o aparelho escolar na formação capitalista.

É pela aprendizagem de alguns saberes contidos na inculcação maciça da ideologia da classe dominante que, em grande parte, são reproduzidas as relações de produção de uma formação social capitalista [...]. Os mecanismos que produzem esse resultado vital para o regime capitalista são naturalmente encobertos e dissimulados por uma ideologia da Escola universalmente aceita (ALTHUSSER, 1983, p. 80).

É na escola que se formam as forças produtivas para o mercado de trabalho, reproduzindo as relações de produção que a formação social capitalista precisa para se reproduzir (ALTHUSSER, 1983). Diferentemente das formações sociais escravistas e do sistema feudal, em que a reprodução do trabalho se dava no local do trabalho, nas sociedades capitalistas a reprodução se dá fora da produção, mais especificamente por meio do sistema escolar.

Não basta educar para o management nas escolas de negócios. É preciso desenvolver um sujeito que creia na positividade do lucro para o bem de toda sociedade, que tenha na ascensão econômica um valor inabalável e que veja os empreendedores como verdadeiros heróis (COSTA; BARROS; MARTINS, 2012). A própria ciência econômica serve como justificação ao capitalismo e ao management, uma vez que se apresentou como uma forma não ideológica de se chegar a um resultado positivo para a sociedade, sendo justa para os melhores e fruto de bem-estar para a maioria. Para Boltanski e Chiapello (2009, p. 44):

Essa concepção permite dar corpo à crença de que a economia constitui uma esfera autônoma, independente da ideologia e da moral, e que obedece a leis positivas, deixando-se de lado o fato de que mesmo essa convição já era produto de um trabalho ideológico, e que ela só pudera constituir-se incorporando - e depois encobrindo com o discurso científico - justificações segundo as quais as leis positivas da economia estão a serviço do bem comum. Especialmente a concepção de que a busca do interesse geral individual serve ao interesse geral foi objeto de um enorme trabalho, incessantemente retomado e aprofundado ao longo de toda a 
história clássica. [...] Nessa perspectiva, só o crescimento das riquezas, seja qual for o seu beneficiário, é considerado critério de bem comum.

Neste contexto, o ensino para o empreendedorismo encontra um terreno fértil para prosperar em todas as esferas da vida do sujeito ${ }^{35}$. Para Lee, Chang e Lim (2005, p. 41, tradução minha), "empreendedores são cultivados durante a sua vida e, assim, o ambiente social e cultural, a experiência pessoal e a educação são muito importantes". Pela forma em que o discurso do empreendedorismo é construído nas universidades e na mídia e, então, assumido pela sociedade, vinculando "de forma acrítica e sem questionamentos, o tema empreendedorismo com o crescimento, desenvolvimento e enriquecimento das organizações e dos indivíduos nas organizações, elegendo e naturalizando o capitalismo de mercado como único modelo possível de desenvolvimento socioeconômico" (COSTA; BARROS; MARTINS, 2012, p. 360), aprende-se que entregar-se à paixão do lucro é justificado pelo bem-estar social que essa atividade irá gerar, uma vez que, o bem-estar individual se traduz no bem-estar da maioria.

Assim, a mídia de negócios, as escolas em Administração, as empresas de consultoria, os gurus do management assumiram a missão de moldar a sociedade conforme uma lógica econômica capitalista, com ênfase no neoliberalismo. Pra isso, não são só os modelos de gestão que são disseminados pela indústria do management. Coisas tão importantes, como a imagem que uma pessoa tem sobre si e sobre os outros, são construídas na sociedade a partir do perfil de indivíduo "moderno" - ambicioso, persistente, realizador e em constante busca pelo sucesso pessoal. Para Ituassu e Tonelli (2014, p. 106), “esse modelo que a publicação ajuda a difundir não é natural, mas foi construído". Construído com o propósito de modificar a essência dos seres humanos.

\footnotetext{
${ }^{35} \mathrm{Um}$ dos métodos para isso é "incorporar métodos de programas educacionais complementares que ligam a educação formal à preparação para o empreendedorismo", defende Hicks (2014, [s/p]). No ensino fundamental e médio a ideologia do management é aplicada de várias formas, mas a mais contundente é a parceria entre escolas públicas e privadas de mais de 120 países, inclusive no Brasil, com a "associação educativa", mantida pela iniciativa privada (leia-se, grandes empresas privadas), Junior Achievement (JA). Seu "objetivo é despertar o espírito empreendedor nos jovens, ainda na escola, estimulando o seu desenvolvimento pessoal, proporcionando uma visão clara do mundo dos negócios e facilitando o acesso ao mercado de trabalho", como consta no site da organização (JUNIOR ACHIEVEMENT, [s.d]). Não nos impressiona, então, que até mesmo as "crianças empreendedoras", educadas na cultura do management, tenham recebido o status de celebridades. Em matéria da revista Exame elas são chamadas de empreendedoras que, até nos momentos em que estão sendo crianças, brincando, "podem estar bolando uma ideia de negócio que pode mudar o mundo ou valer milhares de dólares" (ZUINI, 2012, [s/p], grifo do autor). Abusando da polissemia, brincar passa a significar trabalhar. É quase como se dissessem (ou será que dizem mesmo?) que brincar é perda de tempo se não resultar em algo que pode ser economicamente transacionado. Transformam crianças em pequenos homens e mulheres de negócios, como se isso fosse natural.
} 
Adorno e Horkheimer (1999) veem a eliminação das diferenças como fruto do conformismo a que estão encarceradas as pessoas nas sociedades industriais. Conformismo que é reflexo da dominação "e, ao mesmo tempo, [...] sua ferramenta" (ADORNO; HORKHEIMER, 1999, p. 56). A racionalidade alienada, visto que "o pensar perdeu o elemento da reflexão sobre si", se tornou um meio para a dominação, afirmam Adorno e Horkheimer (1999, p. 56).

Prestes Motta (1979, p. 11) afirma que "a organização é o sistema social mais formalizado da sociedade" e, devido seu alcance e centralidade no mundo moderno, produz "formas de comportamento e formas de raciocínio" que não se reduzem aos seus muros, mas se espalham por toda a sociedade. Nas organizações se produz e reproduz "determinadas relações sociais necessárias à manutenção e expansão do sistema econômico vigente" (PRESTES MOTTA, 1992, p. 39). É desta forma que as organizações se transformam em geradores e reprodutores da ideologia do management, por meio da interiorização dos valores dominantes do "mundo empresarial”.

Os dirigentes das organizações, para esconder suas próprias contradições, incutem sua ideologia nas pessoas, uma vez que elas apresentam "uma visão de mundo coerente com suas aspirações" (PRESTES MOTTA, 1992, p. 44), como se fosse uma religião, atribuindo sentido às suas vidas. Com isso, os membros da organização passam a compartilhar a fé no sucesso individual a partir de seus esforços pessoais, crendo nas oportunidades e nas recompensas que receberão no futuro. Bendassolli (2000, p. 211) lembra que:

\footnotetext{
Nesse ambiente, altera-se a representação social da empresa, a qual deixa de ser percebida como instrumento de dominação dos grandes sobre os pequenos para funcionar como modelo ideal de conduta para o indivíduo, já que ela é símbolo de eficácia e de iniciativas ousadas num contexto turbulento.
}

É assim que, para Faria e Meneghetti (2002), as empresas e outros tipos de organizações disseminam a ideologia dominante e fazem questão de afirmar que qualquer conduta que vá contra essa lógica é indesejável. O discurso da empresa, lembram Rodrigues e Dellagnelo (2013, p. 624), se constitui como "um veículo de manifestação ou legitimação direta da ideologia vigente, seja para convencer, para impor ou para estabelecer acordos sobre o indivíduo". Desta forma, homens e mulheres, para se ajustarem, perdem sua autonomia em troca de uma heteronomia, ou seja, "o indivíduo perde sua individualidade e sua condição de 
sujeito, tornando-se mais um elemento do processo tecnológico de mecanização e padronização" (FARIA; MENEGHETTI, 2002, p. 9). 


\section{O "BRANCO" CHEGOU... E A VIDA MUDOU}

Os "brancos", desde os primeiros contatos com as sociedades indígenas, tentam impor sua racionalidade e seu modo de vida. Apesar da resistência indígena, a eles foram impostas instituições e crenças dos não-índios que, assim, sofreram um grande processo de expoliação econômica e cultural, chegando alguns grupos a serem considerados extintos.

Interesses conflitantes entre os "brancos" recém-chegados e os índios que já ocupavam as terras foram constantes, forçando a modificações na vida dos índios em todo o Brasil, elo mais fraco quando o tipo de desenvolvimento perseguido privilegia o crescimento econômico. No entanto, apesar das previsões catastróficas quanto ao futuro dos índios na sociedade brasileira, eles continuam por aqui e cada dia mais reivindicando o seu lugar. Trata-se, portanto, de uma história de dominação e resistência.

Neste capítulo trato dessas mudanças, focando especificamente nos Kaingang de Apucaraninha, objeto da minha pesquisa, já que o termo índio é bastante genérico e não abarca a dinâmica histórica, social e cultural das cerca de 200 etnias diferentes que vivem no Brasil hoje (FREIRE, 2002). Assim, para não incorrer em interpretações equivocadas, resolvi contar essas mudanças a partir da história dos Kaingang do Paraná, pincelando, algumas vezes, com acontecimentos, histórias e estudos feitos em outras etnias, quando necessário, dado que muitos desses acontecimentos são resultados de forças mais amplas.

Mas não tenho pretensão de entrar na cosmogonia e na descrição antropológica dos Kaingang, uma vez que minha formação não me possibilita isso. Não faço história aqui, mas utilizo da história para começar a compreender por quais processos passaram os Kaingang e como a sociedade "branca", nesta fricção interétnica, forçou a mudanças em seu modo de vida. Como afirmou Freire (2002, p. 2) em uma palestra realizada para os gestores de cultura dos municípios do Rio de Janeiro, "tentar compreender as sociedades indígenas não é apenas procurar conhecer o 'outro', 'o diferente', mas implica conduzir as indagações e reflexões sobre a própria sociedade em que vivemos". 


\subsection{Povo Kaingang: uma história de dominação e resistência}

O sul e parte do Estado de São Paulo são, tradicionalmente, o lar dos índios Kaingang, grupo étnico pertencente ao tronco linguistico Jê, que migraram do Brasil central para o sul há cerca de 3.000 anos (MOTA, 2000). Nestas terras viviam da caça, da coleta e da agricultura rudimentar ${ }^{36}$, ocupando amplos espaços, necessários para a sua reprodução sociocultural, afirma Tommasino (2000).

No entanto, pelo menos nos últimos 150 anos, as terras que essas sociedades ocupam têm sido objeto de cobiça de colonizadores que, contando com o apoio de políticas e ações tutelares estatais, marcaram os processos de territorialidade dos Kaingang no norte do Paraná, uma vez a ocupação de suas terras tradicionais pelos "brancos" implica outra lógica territorial, nos termos em que é defendido por Gallois (2004).

Dele resultam as ações de aldeamento, no final do século XIX, e a formação de reservas indígenas, em grande parte do século XX (Figura 5), que segregaram os indígenas a espaços ínfimos sob a administração de não-índios ${ }^{37}$, insuficientes, portanto, para a sua reprodução sociocultural, visando a sua integração à sociedade brasileira, ao mesmo tempo em que liberava grande parte das terras indígenas à exploração ${ }^{38}$.

A ideia era apagar, mesmo que de forma fictícia, os rastros dos indígenas no Paraná, principalmente nas terras mais a oeste, onde haviam se instalado para fugir das áreas urbanas. É assim que, na primeira metade do século XX, era comum descrever a região além de Londrina, como um "vasto sertão", um "vazio demográfico", não apontando a presença dos indígenas que ali estavam (MOTA, 2008). Portanto, era o local propício aos olhos da ocupação capitalista, tendo as companhias colonizadoras estrangeiras papel central neste processo $^{39}$.

\footnotetext{
${ }^{36}$ Segundo Tommasino (1995), os kaingang preparavam a terra com um machado de pedra, jogavam as sementes e depois abandonavam a roça, só voltando na época da colheita.

37 Inicialmente sob a administração de ordens religiosas que foram, posteriormente, substituídas por administradores laicos.

${ }^{38}$ As terras consideradas abandonadas pelos indígenas, por conta do aldeamento, e as que foram deles tomadas, devido as reservas, eram classificadas como devolutas e incorporadas ao patrimônio estatal. Assim, podiam ser objeto da colonização, o que agravou o processo de grilagem das terras indígenas, segundo Araújo (2006).

39 No norte do Paraná, a colonização esteve a cargo da Companhia de Terras Norte do Paraná (CTNP), subsidiária da inglesa Paraná Plantation. Em 1927, o governo do Paraná concedeu à CTNP 500.000 alqueires de terras devolutas (LUZ; OMURA, 1975). Terras tradicionalmente ocupadas pelos índios Kaingang que, neste momento, estavam sendo transferidos para as reservas.
} 


\section{ÁREAS KAINGANG}

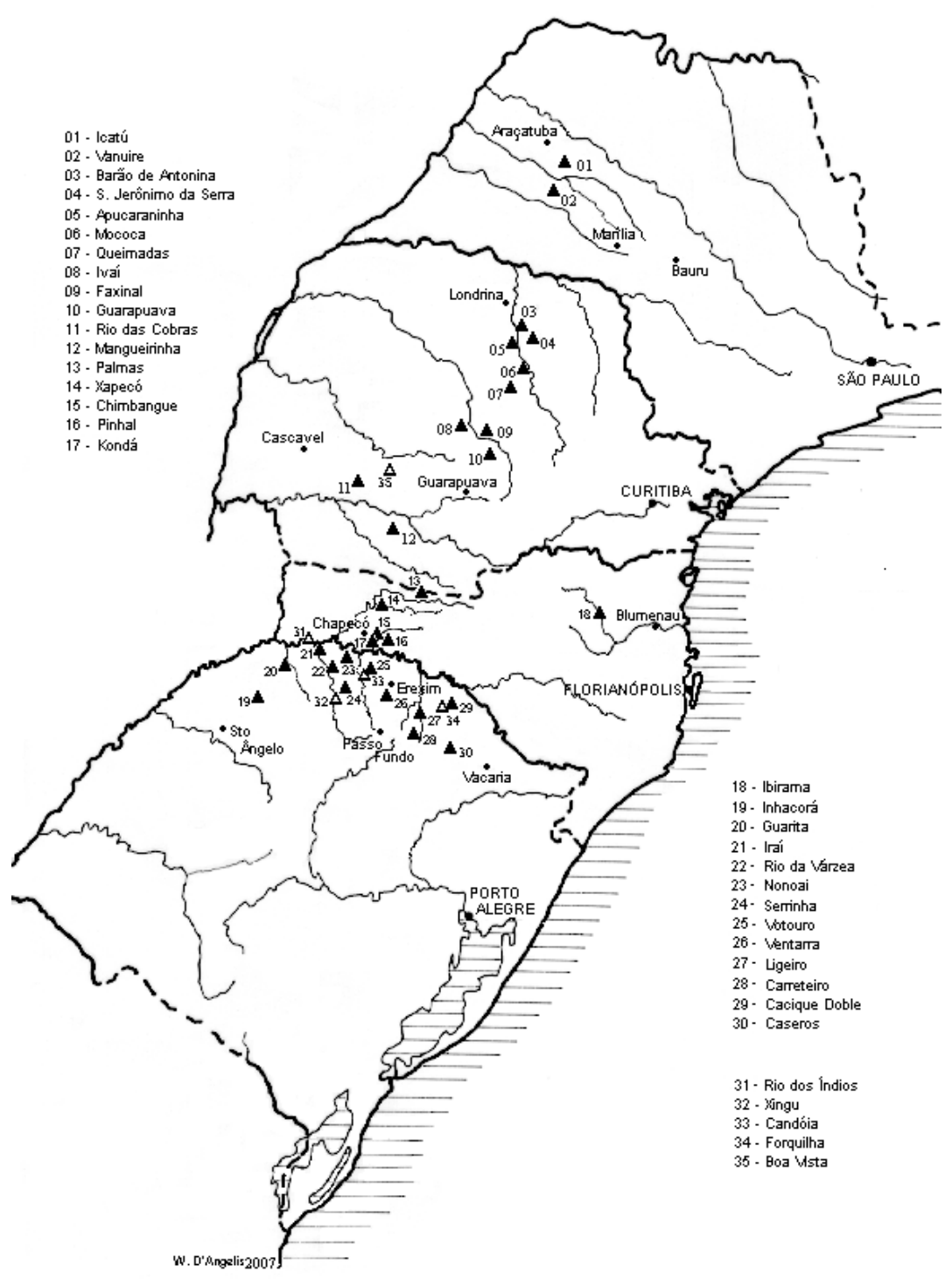

Figura 5 - Áreas atualmente ocupadas pelos Kaingang

Fonte - Adaptado de D'Angelis (2007) apud Portal Kaingang [20--].

No entanto, por trás desse discurso de "zona desabitada", esconde-se uma realidade contraditória, de lutas, subjugação e, como não poderia deixar de ser, de resistência, mesmo que em forma de uma "subordinação intencionada", nas palavras de Novak (2006). Para Tomazi (1997, p. 21), na ocupação do norte do Paraná no começo do século XX, a violência era uma constante que atingia aqueles que não se alinhavam ao ideário do progresso, como índios e posseiros, "que estruturavam suas vidas longe dos padrões que o capitalismo define como modernos". 
É claro que as companhias colonizadoras não ignoravam a presença dos indígenas naquele espaço que chamavam de sertão, mas utilizavam dessa estratégia discursiva para a comercialização das terras, dando a ideia de uma ocupação pacífica, defende Tomazi (1997) ao discorrer sobre o discurso "norte do Paraná".

Assim, o processo de colonização, que se intensificou na primeira metade do século $\mathrm{XX}$ no norte do Paraná, impôs alterações no modo de vida dos Kaingang, já que a colonização do norte do Paraná produziu impactos profundos na paisagem natural daquele espaço. Se antes viviam em imensas florestas, se deslocando pela região para desenvolver suas atividades de coleta, caça, pesca e de agricultura, passam a ser confinados em pequenos espaços, centrados na sedentarização e em uma vida administrada, formas estranhas ao seu modo de vida tradicional.

Para dar lugar a plantações de café, as matas foram quase completamente destruídas, levando às modificações nos fluxos dos rios, na qualidade do solo e, consequentemente, do clima. Essa ocupação, que foi bastante acelerada, "fez com que se produzisse outra natureza, diferente daquela conhecida pelas comunidades indígenas e com a qual se relacionavam, e construíam a sua sociedade", afirma Mota (2008, p. 24).

Ademais, o crescimento vegetativo da população indígena no Brasil se mostra, nas últimas décadas, bastante forte. Segundo Pagliaro, Azevedo e Santos (2005, p. 12), "no plano demográfico, fica evidente que, ao invés de uma tendência de descenso, sua população total vem crescendo em ritmo pronunciado, superando inclusive as médias nacionais". E isso não é diferente entre os Kaingang de Apucaraninha que, por isso, se apertam em um espaço pequeno frente à comunidade crescente. Hoje são cerca de 1300 pessoas, aproximadamente 280 famílias.

É por isso que, dentro das reservas, os Kaigang já não vivem da caça, da pesca, da coleta e da agricultura rudimentar, como seus antepassados ${ }^{40}$. Hoje, só lhes resta viver da agricultura de subsistência, do artesanato e dos serviços que prestam às fazendas da redondeza para complementar a renda (TOMMASINO, 2011). O que, no entanto, não lhes permite sair do

\footnotetext{
${ }^{40}$ No relatório final do diagnóstico do Programa de Sustentabilidade de Apucaraninha foi apontado que grande parte dos indígenas que se dizem agricultores não possuem terras para trabalhar (PROGRAMA DE SUSTENTABILIDADE SÓCIO-AMBIENTAL DA TERRA INDÍGENA DE APUCARANINHA, 2011a).
} 
estado de miséria em que se encontram, realidade bastante diferente do seu passado de abundância.

Da roça realizada na própria TI sobra muito pouco como excedente, servindo a maior parte para o consumo interno. É por isso que alguns indígenas trabalham na própria TI em serviços não agrícolas, na limpeza de escolas, como professores e até como guias e intérpretes, e fora dela, principalmente como diaristas nas propriedades vizinhas e, em alguns casos, na construção civil e no comércio varejista. Além disso, contam com benefícios oferecidos pelo Estado, como aposentadorias, Bolsa Família e cupom alimentação da prefeitura de Londrina. É a combinação dessas diferentes fontes de renda que garante o sustento dos indígenas nas diferentes épocas do ano, aponta Cimbaluk (2013).

Reconhecer esta situação de violência não significa que estou vendo os índios como meras vítimas do processo histórico. Trata-se, mais, do reconhecimento da sua capacidade de resistência, já que foi neste contexto de dominação que os Kaingang construíram uma nova territorialidade ligada, principalmente, a essas estratégias de resistência. Conforme Tommasino (2000, p. 219), a sua forma de relação com o território foi se alterando por meio da mudança e da persistência, "dois lados de um mesmo processo histórico".

Uma mudança que culminou em uma estratégia de resistência pelos Kaingang foi pedir a demarcação de suas terras. Como tinham consciência do interesse dos "brancos" por elas, sabiam que se não houvesse demarcação de suas terras tradicionais corriam o risco de perder o pouco que tinham conseguido conservar até então. O argumento utilizado pelos índios: se querem nos transformar em agricultores, que demarquem nossas terras (MOTA, 2014).

A invasão produzida pela colonização os obriga a pensar dentro da lógica territorial dos "brancos", de delimitação dos espaços exclusivos. "Neste sentido, pode-se dizer que o contato coloca um grupo indígena diante de lógicas espaciais diferentes da sua e que passam a ser expressas também em termos territoriais" (GALLOIS, 2004, p. 41).

O que, a primeira vista, parece simplesmente a posse sobre um determinado espaço, significa a possibilidade da manutenção da sua territorialidade, devido a relação que os Kaingang mantêm com a terra. Diferentemente dos não-índios - que se imaginam apartados da natureza que devem dominar - os Kaingang possuem outro tipo de relação com a natureza, se 
considerando parte dela e utilizando os recursos que disponibiliza. Há, portanto, entre os Kaingang uma relação natureza e cultura que sustenta a sua territorialidade. Segundo Tommasino (2000, p. 211), “o modo de vida kaingang implica uma relação específica com a natureza e entre si, de acordo com representações simbólicas historicamente elaboradas que conferem sentido às suas práticas materiais e sociais".

O que os índios não imaginavam é que continuariam a ser tutelados pelos "brancos" e, assim, obrigados a trabalhar em roças coletivas em troca da alimentação, contrariando a sua forma produtiva tradicional, organizada em famílias extensas ligadas pela relação entre genros e sogros (CIMBALUK, 2014). Para piorar ainda mais a situação, neste momento essas populações passam a ficar confinadas às reservas, lhes tirando a possibilidade de deslocamentos para atividades de subsistência, contatos sociais, rituais e simbólicos ${ }^{41}$.

Para o governo, esta seria uma forma de proteger os índigenas. Até certo ponto, eles tinham razão. As reservas, mesmo que sendo uma pequena parcela da terra tradicional dos Kaingang, permitiram, apesar da necessária readequação do seu modo de vida a esta nova configuração socioeconômica, “a sua existência no vale do Rio Tibagi”, conclui Mota (2014, p. 387), já que o governo do Estado e os colonos estavam determinados a ocupar as terras dos índios.

Conta para isso, claro, as estratégias dos próprios índios de se aliar ao poder republicano para a defesa de suas terras, mesmo que isso significasse simular a aceitação do projeto do recémcriado SPI ${ }^{42}$, Serviço de Proteção aos Índios, de transformá-los em trabalhadores rurais "fixados em lotes de terras vivendo como os nacionais e produzindo mercadorias para o mercado nacional e internacional" (MOTA, 2014, p. 384). Com isso, eles garantiram suas terras, as ferramentas, as sementes e os implementos agrícolas - que nem sempre chegaram a utilizar, avisa Mota (2014) - e a manutenção de alguns de seus costumes.

\footnotetext{
${ }^{41}$ Para Tommasino (1995), na reserva impera a ideia de liberdade vigiada. Em 1945 foi implantado pelo SPI a Guia de Trânsito, uma forma de controle institucionalizada, que exclui a possibilidade de ir e vir dos índios. Por meio dela, os índios são autorizados por no máximo 10 dias a se ausentar da reserva pelos agentes do SPI e, posteriormente, da Fundação Nacional do Índio (FUNAI). Neste momento, integrar os índios à sociedade nacional é feita a partir do filtro do "branco".

${ }^{42}$ Segundo Mota (2014, p. 361), o SPILTN, Serviço de Proteção aos Índios e Localização de Trabalhadores Nacionais, e criado em 1906, era subordinado ao Ministério da Agricultura e foi "instituído com o objetivo de prestar assistência aos índios e alocar trabalhadores nacionais em centros agrícolas". No Paraná foi instalada a inspetoria regional do SPILTN em 1910, em Curitiba. Em 1918, passou a cuidar somente dos povos indígenas e foi renomeado como SPI, tendo sendo extinto e substituído pela FUNAI, Fundação Nacional do Índio, em 1967.
} 
É assim que as sociedades indígenas passam por um período de empobrecimento - tanto em termos materiais quanto culturais - resultado de décadas de expoliação e exploração predatória produzida tanto pela sociedade envolvente quanto pelo Estado. As terras indígenas além de terem sido oficialmente reduzidas, se tornaram objeto de capitalistas que, por meio de $\operatorname{arrendamentos}^{43}$, praticam atividades predatórias que não trazem nenhum retorno às sociedades Kaingang e ainda forçam a mudanças culturais. Para Luciano (2006, p. 115):

O fato sinaliza para uma mudança radical na relação das referidas comunidades indígenas com a sua terra, relação esta dominada pela ótica materialista e economicista que é contrária aos principais fundamentos do direito às suas terras tradicionais. É a força da visão capitalista sobre os povos que praticam o arrendamento ilegal - ilegal porque a lei proíbe qualquer tipo de negócio com a terra indígena.

Veiga (2006) denuncia a prática de arrendamento de terras indígenas no sul do Brasil, de índios para não-índios, e até de índios para índios. Com os arrendamentos, passa a ocorrer um fenômeno novo em comunidades indígenas, a transferência de renda e poder, reproduzindo a estrutura de classes do sistema capitalista.

$\mathrm{Na}$ Terra Indígena Apucaraninha (Figura 6), além da redução territorial forçada ${ }^{44}$, os índios foram obrigados a conviver com uma usina hidrelétrica instalada em suas terras no final da década de 1940 para atender as necessidades energéticas de Londrina, que crescia vigorosamente como resultado do projeto de colonização empreendido por uma empresa privada, a CTNP, Companhia de Terras Norte do Paraná ${ }^{45}$.

\footnotetext{
43 Para Tommasino (1995), em todo sul do Brasil, as terras ocupadas pelos índios foram arrendadas, com autorização dos agentes do SPI e da FUNAI, para famílias não índias. A situação era tão grave que em 1957 uma circular foi distribuída para os chefes de todos os postos indígenas proibindo novos arrendamentos a fim e barrar o desmatamento produzido pela indústria madereira, a exploração de minérios e a implantação de culturas agrícolas mecanizadas. No entanto, a prática de arrendamento voltou a ser implantada pela FUNAI, sendo que em 1976 o INCRA encontrou 24 famílias não índias, cerca de 163 pessoas, arrendatárias no Posto Indígena Apucaraninha

${ }^{44}$ Em 1900, os indígenas de Apucaraninha possuíam um total 68.536 ha. Em 1949, um decreto federal reduz este espaço para 6.300 ha, conforme informações de Novak (2014).

${ }^{45}$ Inicialmente de propriedade da Empresa Elétrica de Londrina S/A (EELSA), uma empresa privada, a usina foi incorporada pela COPEL, companhia de capital misto do setor de energia elétrica do Estado do Paraná, em 1974 (COPEL, 1999). Atualmente a usina abastece as cidades de Londrina e Tamarana, que se emancipou de Londrina em 1995.
} 


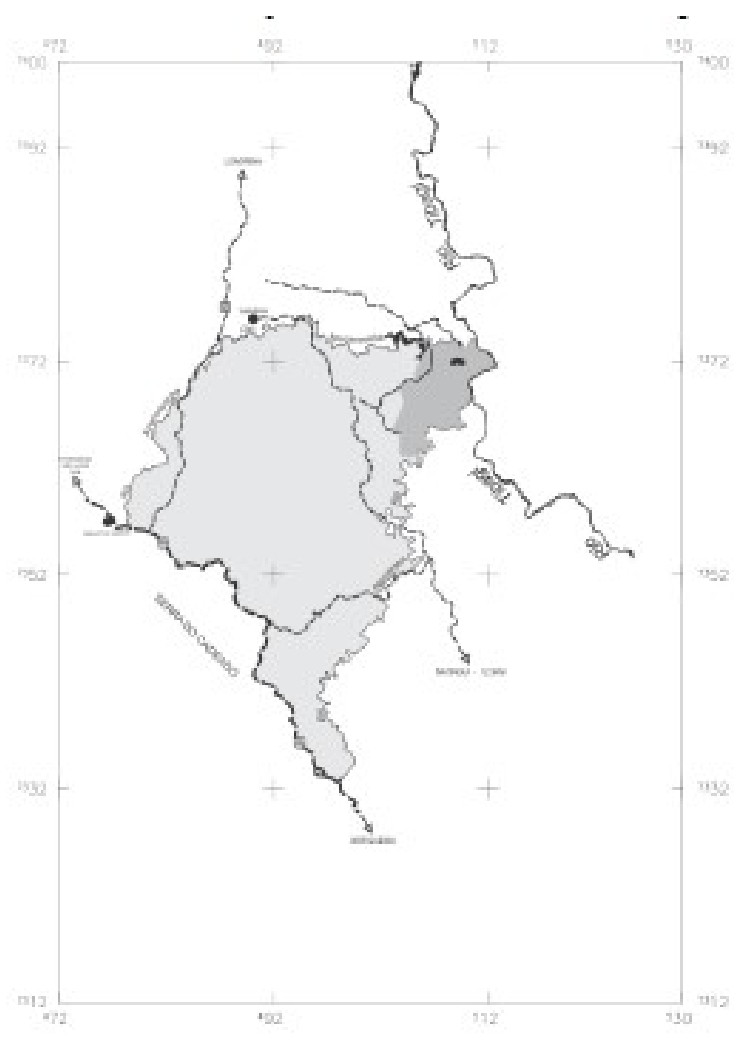

\section{Terra Indigena Apucaraninha}

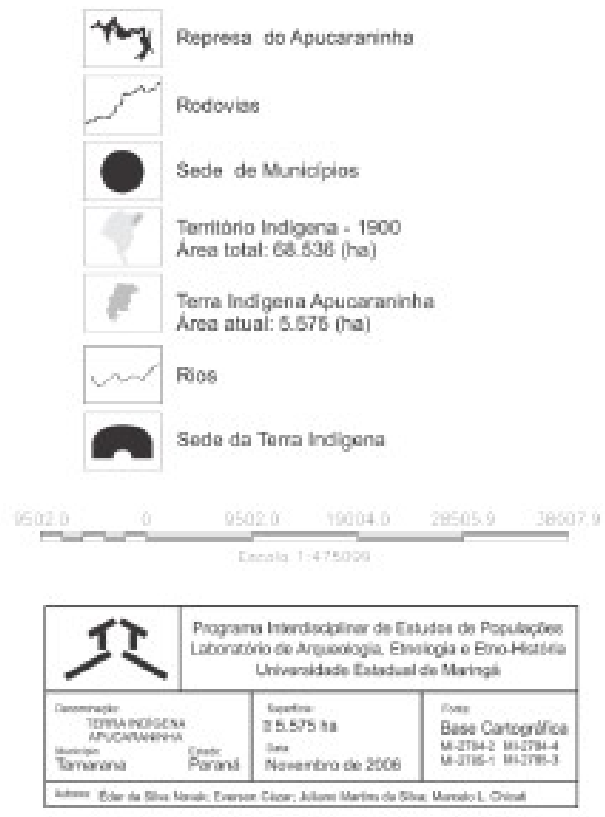

Figura 6 - Redução territorial da Terra Indígena Apucaraninha desde 1900

Fonte - Laboratório de Arqueologia Etnologia e Etno-História da Universidade Estadual de Maringá (2006) apud Novak (2014).

Com capacidade instalada de 9,5 MW, a Usina Hidrelétrica de Apucaraninha possui dois reservatórios ${ }^{46}$ que alagaram parte das terras indígenas, ocupando $276,73 \mathrm{ha}^{47}$, incluindo área de conservação e vila residencial para os funcionários da empresa (CIMBALUK, 2014). Apesar de nos termos atuais ser considerada uma PCH, Pequena Central Hidrelétrica, conforme resolução da ANEEL, Agência Nacional de Energia Elétrica (ANEEL, 2003), a usina de Apucaraninha foi capaz de provocar impactos socioculturais amplos na sociedade Kaingang, uma vez que os recursos ambientais de uma área indígena tem um significado simbólico e prático diferente daqueles em áreas não indígenas. "Isto faz com que qualquer impacto sobre o meio bio-físico em uma área indígena, ainda que mínimo, tenha enormes consequências negativas sobre essas comunidades", aponta o MPF, Ministério Público Federal, em laudo assinado por sua antropóloga Luciana Ramos (MPF, 2005, s/p).

\footnotetext{
46 "A usina funciona com o aproveitamento do Salto Grande, com $125 \mathrm{~m}$ de altura, no rio Apucaraninha. Dois reservatórios fazem parte do projeto, sendo o menor chamado de Apucaraninha, com um milhão de metros cúbicos, próximo à Casa de Força (que possui 3 unidades geradoras). E o outro, de regularização a montante do primeiro, denominado de FIÚ, com 15 milhões de m" (COPEL, 2014).

${ }^{47} \mathrm{ha}=$ hectare.
} 
No momento de sua construção, não se levantava a hipótese de indenizar os indígenas pelas terras que tinham sido alagadas e os danos socioculturais que isso acarretou. Assim, aos índios somente coube um valor anual pelo arrendamento das terras para a instalação da usina, no valor inicial de 36 mil cruzeiros, dos quais era descontado o valor do consumo de energia elda sede do posto do $\mathrm{SPI}^{48}$. Segundo Cimbaluk (2013, p. 94), “o valor pago era questionado pela comunidade, e historicamente foi de difícil apropriação por ela, sendo administrado pelo SPI e depois pela FUNAI".

Durante cerca de 30 anos, os indígenas foram controlados pelos agentes dos órgãos indigenistas que administravam suas terras e, assim, se mantiveram praticamente calados com relação aos valores recebidos como contrapartida para o funcionamento da usina. No entanto, no começo da década de 1980 os Kaingang de Apucaraninha conseguiram se mobilizar e pedir revisão dos valores pagos, neste momento, pela COPEL.

É importante atentar para o fato que, conforme Cimbaluk (2014), as discussões relativas à construção da usina hidrelétrica de São Jerônimo no rio Tibagi, pelas quais os índios foram convidados, pela primeira vez, a participar, impulsionaram os Kaingang de Apucaraninha a pedir revisão dos valores recebidos da COPEL sobre a usina Apucaraninha.

A década de 1980 foi bastante fértil no protagonismo indígena. Afinal, a redemocratização operou mudanças na legislação relativas aos índios, tendo como marco a Constituição de 1988, enquanto ressurgia o orgulho de ser indígena, apoiado pela geração de índios com educação formal ${ }^{49}$. É importante apontar também o surgimento, neste momento quando o contexto político se torna favorável, dos movimentos sociais indígenas nesta equação, permitindo o ingresso dos índios nos espaços políticos e seu reconhecimento como sujeitos sociais, afirma Suárez (2007).

\footnotetext{
${ }^{48}$ Informações a mim repassadas oralmente por Eder Novak, em 09/04/2015, é que este valor coincidia com o valor do consumo de energia elétrica do Posto, conforme dados levantados por ele junto a documentos oficiais disponíveis no Museu do Índio em Brasília. Valor este que, em 2001, equivalia a 56 mil reais anuais, que eram depositados em um fundo gerenciado pela FUNAI, conforme informações encontradas no Mapa de Conflitos Envolvendo Injustiça Ambiental e Saúde no Brasil produzido pela Fundação Osvaldo Cruz (FIOCRUZ) e pela Fase (FIOCRUZ; FASE, 2009)

49 Para Almeida (2014), em seu estudo sobre a organização política Kaingang, muitos índios afirmaram a necessidade de adquirir formação educacional para representar suas comunidades perante a sociedade envolvente. "O confronto com [os "brancos"] já não será mais por meio dos instrumentos de guerra do passado guerreiro como o arco-e-flecha e/ou zarabatana, usando uma metáfora corrente entre os nativos da T.I. Mangueirinha. Para eles, hoje, é preciso saber manusear a caneta com inteligência a favor dos direitos dos povos indígenas" (ALMEIDA, 2014, s/p).
} 
A explosão da indianidade, segundo Castro (2006), operou como uma reação dos indígenas ao discurso que, por tanto tempo repetido, se tornou verdade até mesmo entre eles: de que não eram mais índios. Assim, após tantos anos de um trabalho sistemático visando apagar os índios da sociedade brasileira, eles passam a reivindicar as terras tradicionais que lhes foram tomadas, a retomar seus ritos e símbolos ${ }^{50}$, enfim, a se reconhecer como parte de uma comunidade indígena.

Assim, os indígenas assumem uma posição mais atuante perante suas demandas, conhecendo seus direitos e lutando por eles, tendo as lideranças indígenas assumido um papel mais político. O cacique, a principal liderança da comunidade indígena é, tradicionalmente, visto pelos outros índios como o responsável pela defesa do território contra os invasores ${ }^{51}$ (ALMEIDA, 2014). Para isso, precisa decifrar a lei dos "brancos".

É desta forma que as lideranças em Apucaraninha aprenderam a manter boas relações com o Ministério Público, que é visto por eles como um aliado nas questões políticas, como bem lembrou uma das pessoas entrevistadas que trabalha no MPF. Enquanto os atores externos, como os funcionários da COPEL, temem o MPF, os índios "usam o Ministério Público quando querem", aponta Gisele. Criticam ou se aproximam na hora que entendem ser necessário. Não há, portanto, uma relação de subserviência ${ }^{52}$ entre o Ministério Público e os índios, uma vez que o MPF foi um dos primeiros aliados dos indígenas na sua luta por direitos.

\footnotetext{
${ }^{50}$ Há um debate sobre o que há de autêntico nestes rituais e símbolos indígenas. No entanto, ganha mais força o grupo que defende que "a tradição não é um corpus fechado que persiste no tempo" (COHN, 2001, p. 38, grifo da autora). É claro que neste processo todo, que é histórico e, portanto, mutável, fica impossível definir a autenticidade de qualquer coisa. Assim, não cabe a nós definir o que é ou não autêntico entre as práticas culturais indígenas atuais, já que "não há culturas inautênticas, pois não há culturas autênticas" (CASTRO, 2006, p. 46). O que importa é que os próprios índios se reconheçam nesses rituais e símbolos culturais que, naturalmente, foram reatualizados por meio da "fricção interétnica", conceito desenvolvido por Oliveira (2006).

${ }^{51}$ É por isso que precisa ser exemplo moral de conduta, não se envolvendo com bebida ou com mulheres, como afirmou o índio João, uma das lideranças de Apucaraninha, para ter condições de dar conselhos aos outros índios. A confiança é um dos pilares da liderança indígena. Quando há a quebra da confiança, os índios podem buscar destituir o cacique. Se não conseguem, se afastam para outras comunidades indígenas ou fundam outra aldeia.

${ }_{52}$ Tanto é assim que, por muitas vezes, foram os procuradores do MPF que tiveram que se impor sobre os índios. Um dos entevistados me contou que em dado momento, um dos procuradores do MPF de Londrina estava na terra indígena e, ao não chegarem a um acordo sobre o assunto que estavam discutindo, fora advertido de que seria proibido de sair da aldeia naquele dia. A saída do procurador foi ameaçá-los de volta: "façam isso que, daqui à uma hora, isto aqui estará cercado pela Polícia Federal". Os indígenas entenderam o recado e deixaram o procurador livre.
} 
Assim, após diversas mobilizações e com intermediação do Ministério Público Federal, em 2001, os índios conseguiram declarar nulos os acordos anteriormente feitos com as empresas responsáveis pela usina, lembra Cimbaluk (2014). Em um primeiro momento, na redução do espaço ocupado pela usina na TI em cerca de 236 ha, passando a 39,9 ha (CIMBALUK, 2014), devido a retirada da vila de empregados e outras áreas que estavam sobre o controle da COPEL, mas que não eram imprescindíveis ao funcionamento da usina. Além disso, esta empresa concordou com a revisão dos valores pagos à Terra Indígena de Apucaraninha como compensação pelos impactos causados pela instalação da usina.

Entre 2002 e 2005 foram feitos estudos para avaliação dos impactos econômicos, culturais e ambientais acarretados pela usina entre 1946, ano em que as obras da usina começaram, e 2002. A dificuldade maior era avaliar economicamente aquilo que não têm valor material, como a cultura e o meio ambiente. Foi assim que as avaliações chegaram a resultados muito diferentes, entre 5 milhões, consultoria contratada pela COPEL, e 80 milhões de reais, contratada pela FUNAI, Fundação Nacional do Índio. Estava instalado o imbróglio.

O acordo só sai em 2006, após os índios ocuparem a sala de máquinas da usina e manterem funcionários da COPEL retidos e, assim, serem chamados pela empresa para uma reunião, em que compareceram vestidos para a guerra, deixando simbolicamente marcado o que aquele encontro significava para eles. Segundo relato de Cimbaluk (2014, p. 11):

\footnotetext{
Os índios então se pintaram para a guerra, colocaram cocares e foram armados com suas lanças e um machado de pedra. Chegando ao local, em um auditório, diretores e representantes dos órgãos estatais à mesa, e os índios nas primeiras fileiras da plateia. Guerreiros com lanças, frente a frente com o diretor [da companhia de eletricidade]. A empresa dava seus "lances". Os índios saíam para discutir as propostas.
}

Neste momento os conflitos foram parcialmente resolvidos com a assinatura de um acordo entre os indígenas e a COPEL, prevendo o pagamento de uma indenização no valor de 14 milhões de reais pelos impactos causados pela usina, sendo $20 \%$ pago diretamente aos índios e os $80 \%$ restante dependentes de projetos de sustentabilidade pelo qual seriam contratados consultores pela COPEL, conforme Termo de Ajustamento de Conduta (MPF, 2006). 
Os 20\% foram divididos pelas famílias Kaingang de Apucaraninha, cabendo a cada uma, conforme a quantidade de membros, cerca de $\mathrm{R} \$ 2.000,00$. No dia da entrega do dinheiro às famílias formou-se uma operação de segurança na aldeia, sendo utilizado um carro forte para transporte dos valores protegido por viaturas da Polícia Federal. Os índios nunca tinham visto aquilo, alguns chegando a acreditar que tinham ficado ricos.

Os comerciantes das cidades vizinhas, sabendo que os índios estavam com dinheiro, invadiram a aldeia. Um deles chegou a alugar um salão em Apucaraninha para vender móveis para os índios. Rapidamente os estoques acabaram. Os índios, sedentos pelo consumo, compraram de tudo: celular, bicicleta, aparelho de DVD, móveis, carros e motos. Segundo João, que também recebeu sua parte, foi uma festa:

\footnotetext{
Uns compravam carro sem documento, outro bicicleta, moto... Carregavam aparelho nas costas pra lá e pra cá. No outro dia não tinha mais dinheiro, não. Nós divide, mas nós não sabemos guardar dinheiro. Eu falo pra minha mulher que era pra gente ter guardado uns troco, mas não tem nada. Eu, o índio quer dinheiro... o máximo que durou na carteira dele foi meia hora e depois já não tem mais nada. (João, kaingang da TI Apucaraninha)
}

A justificativa para que $80 \%$ dos recursos fossem investidos no programa de desenvolvimento foi justamente a possibilidade dos índios gastarem tudo rapidamente e, no caso da COPEL, como veremos mais adiante, irem buscar mais. Dentro da lógica dos "brancos", o dinheiro deve render para que as gerações futuras não fiquem desprotegidas. Além do mais, como me avisou o pessoal do Ministério Público Federal, sempre há a possibilidade de alguns membros da comunidade se apoderarem do dinheiro deixando o restante à mingua.

Inicialmente ficou acordado, no TAC assinado em 2006 (MPF, 2006), que a COPEL iria contratar uma empresa de consultoria, por meio de procedimento licitatório, para realizar o diagnóstico socioeconômico, cultural e ambiental da Terra Indígena de Apucaraninha. No entanto, passados três anos da assinatura do TAC, a empresa ainda não tinha sido contratada “em função das múltiplas impugnações, administrativas e judiciais, apresentadas pelas empresas concorrentes à licitação publicada pela Copel” (MPF, 2010, s/p). Sendo assim, houve a necessidade de rever o conteúdo do TAC e ficou autorizado o contrato entre as Instituições de Ensino Superior da região, Universidade Estadual de Londrina e Universidade 
Estadual de Maringá, e a COPEL para que os pesquisadores dessas instituições assumissem as ações previstas para as empresas de consultoria.

Nesse meio tempo, devido os atrasos na celebração do contrato para os trabalhos de diagnóstico, houve necessidade de liberar parte dos recursos para atender projetos agrícolas emergenciais na TI, atenuando os ânimos dos indígenas que já estavam descontentes com a demora nas ações. Enquanto duraram os projetos emergenciais, muitos índios foram contratados pelo programa para atuar nos projetos em troca de diárias.

Isso é constantemente lembrado pelos indígenas como um tempo bom, em que eles estavam felizes. Para Joaquim, no começo o programa ajudou muita gente, pois empregou muitos índios:

Primeiro ajudou, sabe. Primeiro ajudou. Hoje eu não sei, porque primeiro eu estava lá embaixo sabe, daí eles fizeram, plantaram algumas coisas pra nós, fizeram um trabalho de área aí ó. Daí eles pagavam pra gente, né. Aí foi cortando, foi cortando... Aí todo mundo estava contente naquela época, sabe. Estava todo mundo contente. (Joaquim, kaingang da TI Apucaraninha).

Só que quando os programas emergenciais acabaram, as diárias foram bastante reduzidas e eles começam a questionar a validade do programa, já que não estão vendo mais a cor do dinheiro e nem o funcionamento dos projetos. Joaquim (Kaingang, TI Apucaraninha), por exemplo, exprime todo seu arrependimento de ter assinado o acordo: "era pra nós não assinar, mas nós assinamos. Então é esse que está dando rolo agora”.

Tanto que fui várias vezes indagada pelos indígenas se havia a possibilidade de romper o acordo e rever o programa, alguns deixando claro que eles queriam que o restante do fundo fosse dividido entre eles, uma vez que outras usinas hidrelétricas iriam ser construídas no rio 
Tibagi $^{53} \mathrm{e}$, assim, receberiam outras indenizações, como já ocorreu com as usinas de Apucaraninha e de Mauá ${ }^{54}$.

Após alguns anos com estes dois programas, a opinião de alguns dos Kaingang de Apucaraninha sobre a construção de usinas hidrelétricas mudou. Pelo menos, foi o que pude apreender nas conversas que tive com os indígenas. Enquanto anos atrás, antes da entrada dos programas de desenvolvimento na terra indígena, os índios se colocavam contra a construção das hidrelétricas (HELM, 2007), hoje já é possível encontrar uma postura bem diferente: agora esperam ansiosamente a implantação das novas usinas devido à indenização.

Assim, me deparei com diversos índios animados com a construção das usinas hidrelétricas no rio Tibagi, já que vislumbram o recebimento das indenizações. Com um olhar de curto prazo, parece que os Kaingang estão se iludindo ao crer que os impactos negativos das usinas podem ser revertidos em benefícios a partir dos programas compensatórios assistencialistas, da mesma forma que os Waiwai ${ }^{55}$ e os Waimiri-Atroari que foram instrumentalizados pela Eletronorte para acreditar que as usinas hidrelétricas na região podem ajudar os índios a "dar certo" (BAINES, 2000).

É assim que o movimento indígena parece estar mudando de direção. Na década de 1980, o movimento indígena estava atrelado à construção de uma identidade estritamente política, em um horizonte de atuação em que a principal reivindicação era a demarcação de suas terras. A indianidade, que lhes assegura o direito de se afirmarem como pessoas étnica e culturalmente diferentes dos "brancos", se apresenta, portanto, como uma resistência à tutela, mais próximas de um relacionamento entre iguais em que índios e "brancos" detêm conhecimentos (GALLOIS, 2002).

\footnotetext{
53 Duas outras usinas hidrelétricas são planejadas para o rio Tibagi: UHE São Jerônimo, entre os municípios de Tamarana e São Jerônimo da Serra, e UHE Telêmaco Borba, no município de mesmo nome.

54 Além da indenização pela Usina Apucaraninha, os Kaingang receberam a compensação, também por meio de um programa, o Programa Básico Ambiental (PBA), pela Usina Hidrelétrica de Mauá que entrou em operação em 2012. A Terra Indígena Apucaraninha, ao contrário das Terras Indígenas Mococa e Queimadas, não foi diretamente impactada pela Usina de Mauá, mas entrou no processo de compensação após o Ministério Público Federal apontar que há uma "unidade cultural, sociológica e histórica" entre as comunidades Kaingang do Estado (GÓES, 2014, p. 9).

55 Os Waiwai, aliás, são convidados a visitar a aldeia dos Waimiri-Atroari para que vejam como a hidrelétrica trouxe benefícios a eles com a compensação recebida. É desta forma "que os Waiwai querem que a Eletronorte construa a planejada Usina Hidrelétrica Cachoeira Porteira para ganhar benefícios compensatórios parecidos àqueles desfrutados pelos Waimiri-Atroari”, lembra Baines (2000, p. 144).
} 
Entretanto, na virada da década de 1980/1990, a dinâmica dos movimentos indígenas se altera e passa a operar orientada pelo o que Albert (2000, p. 198) chamou de "etnicidade de resultados", quando a "a afirmação identitária se tornou pano de fundo para a busca de acesso ao mercado e, sobretudo, ao 'mercado dos projetos' internacional e nacional aberto pelas novas políticas descentralizadas de desenvolvimento (local/sustentável)”.

Muitas organizações indígenas foram criadas para atender as demandas locais, algumas especificamente para acessar os recursos dos grandes projetos que começaram a surgir neste período, deixando em segundo plano as lutas mais amplas pelos direitos dos povos indígenas, como afirma Euclides Pereira, líder do povo Macuxi de Roraima que atua no movimento indígena desde a década de 1980, em entrevista dada a Sousa (2010). O movimento indígena, agora institucionalizado como representante das diversas comunidades indígenas, perde, então, sua característica mais política uma vez que passa a se preocupar principalmente em gerar empregos nas aldeias ou construir campos de futebol.

Com a retração do Estado na década de 1990 devido às políticas neoliberais, as comunidades indígenas, principalmente na região amazônica, passam a ser objetos de diversas organizações, nacionais e internacionais, que prometem o seu acesso a fontes de financiamentos que permitiriam a sua reprodução sociocultural. O problema é que a ideia que sustenta essas organizações, na maior parte das vezes, é o desejo de ultrapassar a mera compensação pelos prejuízos causados por uma história de expoliação, mas estabelecer novos contornos para o futuro dos índios por meio do acesso a recursos e sua inserção na economia de mercado (SOUZA, 2003).

Neste contexto, os programas de desenvolvimento passam a ser utilizados como ferramentas para a resolução de conflitos entre comunidades indígenas e empresas que exploram os recursos em suas terras, como as mineradoras e as de geração de energia. Um dos casos mais conhecidos é o PWA, Programa Waimiri-Atroari, desenvolvido pela Eletronorte com os recursos da indenização devida aos índios Waimiri-Atroari pelas perdas sofridas com a construção da Usina Hidrelétrica de Balbina.

Baines (1993; 1994), antropólogo da Universidade de Brasília, é um dos grandes críticos deste modelo, principalmente por ele representar a privatização do indigenismo e, assim, o redirecionamento da vida dos indígenas conforme os interesses empresariais. A maneira como 
são configurados esses programas o conceito de autodeterminação, constantemente utilizado como retórica, fica subordinado ao de dominação na forma de "autodeterminação dirigida" em que os indígenas passam a defender os interesses das empresas como se fossem os seus.

Assim, apesar do discurso, a autonomia indígena não parece ser reconhecida por aqueles que insistem em manter práticas muito parecidas com a tutela, que se desdobra em paternalismo e assistencialismo, implantando programas de desenvolvimento que ignoram os aspectos socioculturais dos índios, defende (ALMEIDA, 2006). Mas isso é assunto para o próximo capítulo. 


\section{PROGRAMA DE ÍNDIO OU PROGRAMA DE “BRANCO”?}

Com o acordo feito entre os Kaingang de Apucaraninha e a COPEL com intermediação do Ministério Público Federal para a indenização pelo funcionamento da Usina Hidrelétrica de Apucaraninha, foi criado o Programa de Sustentabilidade Socioambiental e Cultural da Terra Indígena Apucaraninha, como visto anteriormente.

Teoricamente pensado como um programa inovador, desenhado sobre uma nova política indigenista em que se buscava corrigir os erros cometidos em projetos anteriores, quando o objetivo era assimilar os índios ao restante da sociedade brasileira, na prática ele se tornou uma repetição do passado. Fico com a sensação de que a história se repete, parafraseando Marx (2011, p. 25), “a primeira vez como tragédia, a segunda como farsa".

Se a política indigenista assimilacionista ${ }^{56}$, praticada formalmente até o final da década de 1980 pelo Estado brasileiro, se constitui uma tragédia, resultando na destruição de povos indígenas, a nova política indigenista posta em prática nos últimos anos, teoricamente sustentada sob a autonomia e rompendo com os preceitos evolucionistas e da homogeneidade racial, se transformou em uma farsa, uma vez que o diálogo interétnico não se constitui na prática (OLIVEIRA, 2001), resultando em um novo tipo de dominação, ainda tendo como objetivo integrar os indígenas a sociedade capitalista.

Cooptado pela empresa de energia, o programa se transformou em mais um projeto que visa impor aos índios o modo de vida do "mundo dos brancos" ignorando as vozes da comunidade. Como as experiências do passado, o projeto aplica um indigenismo assimilacionista e, portanto, já nasce contraditório: ao mesmo tempo em que diz se orientar pelo respeito às diferenças culturais, impõe mudanças aos indígenas de forma a torná-los mais integrados à sociedade nacional. Assim, utilizando discursos de autonomia, autossustentabilidade, participação e desenvolvimento, promete a libertação e, consequentemente, a melhoria na qualidade de vida, enquanto pratica uma nova forma de tutela que visa a sua dominação.

\footnotetext{
${ }^{56}$ As políticas assimilacionistas são concebidas a partir da ideia de que os povos indígenas devem ser integrados à sociedade brasileira. Trata-se de uma visão lastreada na crença no evolucionismo e na homogeneidade racial, dado que integrar os índios à "comunhão nacional" significaria o abandono de suas práticas culturais atrasadas em nome do seu progresso e, consequentemente, de toda a sociedade brasileira.
} 


\subsection{Quem é que manda aqui?}

Os primeiros projetos de desenvolvimento para as comunidades indígenas foram implantadas pelo SPI e pela FUNAI, visando à integração dos índios na dinâmica produtiva da sociedade capitalista (NÖTZOLD; BRINGMANN, 2013). A ideia principal era reduzir os gastos do Estado com a manutenção das aldeias indígenas, ao mesmo tempo em que inseria trabalhadores no mercado, "aumentando a utilidade dos indígenas para a economia brasileira", afirmam Nötzold e Bringmann (2013, p. 151).

Orientados por uma visão empresarial ligada à ideia de autossustentabilidade das comunidades indígenas, as àreas indígenas foram transformadas em "empresas, dedicadas à produção e ao lucro", tornando os indígenas instrumentos do progresso, afirma Santos (1975 apud TOMMASINO, 1995, p. 194). Assim, foram criados o Programa Pecuário e a Campanha do Trigo, na década de 1940, que, apesar do relativo sucesso, poucos benefícios trouxeram aos indígenas, sendo estes apenas o pagamento das diárias, o fornecimento de alimentos e algumas sementes em troca do seu trabalho (NÖTZOLD; BRINGMANN, 2013).

Na década de 1980, resgatando a mesma mentalidade dos projetos que vigoraram até meados do século, é criado o Projeto de Desenvolvimento Agrícola, pelo qual foram instituídas roças coletivas administradas pelo pessoal da FUNAI. O funcionamento do programa se dava da seguinte forma:

Os índios que se engajavam no Projeto recebiam uma "cantina", que compunha-se de gêneros alimentícios distribuídos semanalmente, cujo valor era descontado no final da colheita. Serviços de plantio e carpa das roças eram pagos em diárias para os índios envolvidos. Na fase em que as roças já estavam formadas, estas eram divididas entre as famílias e cada qual tinha que cuidar de sua parte até a época da colheita e o pagamento das diárias er a suspenso. Nessa segunda fase, segundo dizem os técnicos da FUNAI, os índios acabavam abandonando as roças, que em geral se perdia ou tinha a produção comprometida (TOMMASINO, 1995, p. 195).

Como já havia acontecido com os programas anteriores, o projeto acabou não tendo sucesso e foi interrompido alguns anos depois. A explicação dada pelos agentes da FUNAI para o 
insucesso do projeto, como sempre, foi devido a causas externas, como a falta de recursos e a falta de interesse dos índios. Mas, segundo Tommasino (1995), mais uma vez tentava se implantar um modelo que não levava em consideração o modo de vida dos indígenas, mostrando o total desconhecimento da FUNAI sobre os seus aspectos socioculturais.

$\mathrm{Na}$ lógica Kaingang, ao trabalharem nas roças coletivas implantadas pelos órgãos indigenistas, os índios não estão fazendo algo para eles ou para sua comunidade, mas um trabalho para os agentes desses órgãos, afinal, recebem as diárias e a cantina para isso. É bom lembrar que a agricultura moderna não faz parte do modo de vida tradicional dos Kaingang. Portanto, para os índios, há uma relação de reciprocidade nesta atividade. Se param de receber, se tornam escravos, explica Tommasino (1995).

Com a quebra do monopólio tutelar de um único órgão estatal como agente de interlocução com as comunidades indígenas na década de 1990, houve uma disseminação de intervenções socioeconômicas por meio de projetos e programas com a participação de diferentes órgãos públicos e organizações nacionais e internacionais, formando um verdadeiro "mercado de projetos", termo cunhado por Albert (2000) para se referir ao processo de multiplicação de projetos entre os povos indígenas.

Pelo menos na teoria, neste momento há maior preocupação com relação à participação dos índios na formulação, implantação e gestão dos programas e projetos, conforme a ideologia participativa disseminada. Assim, a gestão participativa passa a ser encarada como um remédio para os erros ocorridos nos programas de desenvolvimento indígena no passado, ignorando o que Venosa (1974, p. 80) já havia dito ainda na primeira metade da década de 1970 sobre este modelo de gestão: “a simples circunstância de 'colocar' as pessoas 'juntas' não as fará participar", dado que as formas organizacionais hierarquizadas estão internalizadas na sociedade.

A estratégia agora é incutir a ideia de que é "dada" autonomia aos indígenas a partir do momento em que as rédeas de seu destino estão em suas mãos e, diferentemente do passado, nenhuma regra é imposta de fora. Dissemina-se a ideia da reconstrução das nações indígenas que, para Jorgensen (2007), está baseada no conceito de autogoverno e autodeterminação para 
o desenvolvimento econômico, bem na linha da recém-aprovada Declaração das Nações Unidas sobre os Direitos dos Povos Indígenas ${ }^{57}$ (NAÇÕES UNIDAS, 2008).

Foi com este espírito que surgiu a ideia do Programa de Sustentabilidade na Terra Indígena de Apucaraninha. Conforme o TR, Termo de Referência, que orientou os trabalhos dos consultores que fizeram o diagnóstico, o programa deveria ser "conduzido com a utilização de métodos participativos, observando-se os aspectos sócio-culturais próprios dos Kaingang" (MPF, 2006, p. 6). Para tanto, desde a elaboração do TR fora prevista a participação de um grupo de representantes ${ }^{58}$ da COPEL, da Comunidade Indígena e um antropólogo indicado por ela.

No entanto, os problemas já começaram aqui. Primeiro, que todas essas pessoas seriam coordenadas pela COPEL que iria, então, arcar com os custos da consultoria (MPF, 2006). Na cabeça dos envolvidos, como a companhia tinha mais expertise em gestão do que os outros participantes, era natural que a atividade de coordenação coubesse a ela, conforme podemos ver na fala de Luciano, que trabalha no MPF:

Me parece que a presença da COPEL tentaria trazer um pouco de conhecimento técnico na utilização desse recurso. Então, eu imagino que a presença da COPEL nessa gestão seja pra tentar fazer com que o dinheiro seja realmente utilizado para alcançar uma gestão autossustentável da Terra Indígena, que é o ideal do projeto. Tentar ver as áreas que são agricultáveis, tentar fazer programas que eles consigam fazer a gestão e conseguir os recursos que eles precisam dessa gestão. (Luciano, MPF)

É possível ver na fala de Luciano a sua preocupação com os aspectos técnicos de gestão, chegando ao ponto de colocá-los como primordiais para o programa. Mas isso é compreensível já que ele vê como objetivo principal do programa a autossustentabilidade da comunidade indígena. Autossustentabilidade, neste caso, significando a capacidade de se sustentar com recursos próprios, sem depender da ajuda do governo ou de outras

\footnotetext{
${ }^{57}$ Em 2007, após mais de 20 anos de discussões, foi aprovada na ONU a Declaração das Nações Unidas sobre os Direitos dos Povos Indígenas. O conceito basilar desta declaração está na autodeterminação dos povos indígenas, ou seja, o direito pelo qual as comunidades indígenas têm de determinar "livremente sua condição política [e buscar] seu desenvolvimento econômico social e cultural" (NAÇÕES UNIDAS, 2008, p. 7).

${ }^{58}$ Era prevista também a participação de um representante da Funai, mas, devido ao desmantelamento dessa organização a partir do final da década de 1990, em que os recursos materiais e humanos se tornaram escassos (FEITOSA, 2006), ela nunca foi efetivada de fato.
} 
organizações, como podemos ver nas selexões lexicais ligadas à produção (“áreas que são agricultáveis") e reprodução de recursos (“conseguir os recursos” por meio da gestão).

Em outro trecho, Luciano explica melhor essa questão da autossustentabilidade:

Uma gestão que eles consigam ter autonomia e não depender tanto de recursos dos brancos, digamos assim. Eles, com base nesse dinheiro, conseguirem desenvolver os projetos, ainda que eles vendam o excedente, não há problema nisso. O problema é que eles façam isso de uma maneira que eles consigam gerir a terra indígena. Até esse financeiro pendendo para o lado da autonomia que a Constituição dá aos povos indígenas. Eles têm autonomia. Quem tem autonomia tem que ter dinheiro, né? Tem que ter recurso. (Luciano, MPF)

Assim, gestão e libertação se entrecruzam no discurso de Luciano. Para ele, ao gerir eficientemente a Terra Indígena, os Kaingang passam a gerar recursos financeiros suficientes para livrá-los da tutela dos "brancos". Afinal, "quem tem autonomia tem que ter dinheiro", faz questão de frisar. Está presente em seu discurso, portanto, o discurso do capitalismo que se funda nos princípios de liberdade e autonomia que alicerçam o sistema economômico capitalista, desconsiderando o contexto histórico que produziu o empobrecimento das comunidades indígenas no Paraná que passa necessariamente pelo fortalecimento do próprio capitalismo.

Para Boltanski e Chiapello (2009, p. 423), “o discurso da libertação, desde sua formação, constitui um dos componentes essenciais do espírito do capitalismo", oferecendo a única perspectiva para que as pessoas possam se livrar da opressão oferecida pelas sociedades tradicionais e, assim, se realizar individualmente. Entretanto, por trás desta promessa estão novos dispositivos opressivos, a disciplina se constituindo como a maior entre eles.

"Sob o império do capitalismo, a promessa de libertação funcionaria como uma ideologia, no sentido marxista do termo, possibilitando garantir a sujeição das pessoas à sua ordem" (BOLTANSKI; CHIAPELLO, 2009, p. 426). Ao serem "desenraizadas", ou seja, tiradas "de seus universos concretos de existência e das normas, e também das proteções a estes vinculadas", nos termos de Boltanski e Chiapello (2009, p. 426), os sujeitos perdem sua 
capacidade de resistir à disciplina imposta pelo mercado. Assim, ao invés da libertação, encontram uma nova forma de escravidão. Em outros termos, esta é a mesma opinião de Meneghetti (2007, p. 8):

A racionalização e todo seu discurso de "libertação" não passam de uma grande fantasia para aprisionar a subjetividade dos indivíduos, promovendo, desse modo, um encantamento fetichizado para adquirir legitimação na ação de racionalização do mundo. Assim, o que prevalece é a tentativa de instrumentalização da liberdade com o intuito de adotá-la muito mais como instrumento de reprodução social da repressão original, do que como forma de emancipação ou esclarecimento dos indivíduos.

Assim, embora Luciano fale sobre a autonomia, até citando a autogestão dos indígenas (“programas que eles consigam fazer a gestão"), ele dá ênfase à competência técnica da COPEL como segurança para o sucesso do programa. O fato é que Luciano, como muitos outros participantes do programa, não acredita que os indígenas estejam preparados para gerir o programa, principalmente se se mantiverem índios, sendo necessária a participação da COPEL, ratificando a dependência história.

Essa fé na companhia fez com que ela tivesse quase total liberdade para desenhar o programa conforme suas intenções, já que o TR fora criado por um dos seus diretores, restando aos outros participantes apenas legitimar aquilo que a maioria deles nem tinha conseguido compreender ("tem termos ali de economês"). As diretrizes para a execução do diagnóstico e desenvolvimento do programa foram definidas de uma forma tal que havia necessidade de um conhecimento mais específico em gestão para entender o que estava sendo pedido, dado que o TR era desenhado a partir de uma visão empresarial ("pérola de [...] business"), orientado para o lucro (“o espirito do TR, é o espirito, sei lá, como o crédito do BNDES”).

O primeiro negociador-chefe, representante da COPEL, era um engenheiro. Esse engenheiro tinha a equipe que o ajudava, mas eles não tinham uma assessoria, vamos disser assim, antropologicamente informada. Não tinha nenhum antropólogo, sociólogo... E aí, assim, se você lê o termo de referência é uma pérola de... é ... business. Você tem termos ali de economês que, até mesmo no ambiente empresarial aquilo ali é jargão, as pessoas não falam no cotidiano daquele jeito. Taxa interna de retorno, umas coisas assim 
que você fica... puxa, é uma coisa muito especifica mesmo, que no dia-a-dia nenhuma empresa trata daquilo, você usa expressões mais populares, de algum jeito mais simples, né? Então, aquilo ficou cristalizado no Termos de Referência - o Termo de Referência foi o documento que norteou a partir dali a relação contratual da COPEL, com UEM e UEL. E a gente tinha que fazer coisas de acordo com esse Termo de Referência. Foi muito complicado, porque os antropólogos chamavam aquilo de lixo pra baixo. Eles diziam que aquilo era uma coisa que não tinha o menor sentindo num trabalho voltado pra uma comunidade indígena. $\mathrm{O}$ espírito daquilo tudo era simplesmente o de uma indenização, uma compensação, pelo dano que a usina tinha causado, que a ideia de se fazer projetos era só para que o dinheiro não fosse injetado em cash, assim na mão deles e gerar mais danos do que a usina já tinha gerado. Mas, ao mesmo tempo, ele - [o economista] era forçado, pelo termo de referência, a olhar para os projetos desse ponto de vista: então, a fábrica de farinha vai dar lucro, não vai dar lucro, vai ser sustentável, vai dar retorno, não vai dar retorno? [...] O espirito do TR, é o espirito, sei lá, como o crédito do BNDES. Você pega esse dinheiro, entendeu? Trata ele com cuidado. Ele tem que pagar o empréstimo e continuar dando lucro. Você tem que ter retorno, tem que crescer. Esse é o espirito do TR. Eu apaguei o nome da pessoa [que fez o TR], desse engenheiro, até uma coisa meio freudiana. Porque nós xingamos tanto esse cara, tanto. Cada hora que a gente tinha uma dúvida, "será que pode isso? Vamos no TR ver". Catava o TR, estava lá a marca do cartesianismo do engenheiro. Aí gente fala: "nossa senhora, maldito seja". (José, consultor do programa na área de biologia)

Quatro são os efeitos disso no programa: 1) um peso exagerado é dado aos projetos que se mostram financeiramente viáveis, mesmo que eles se contraponham ao modo de vida dos indígenas; 2) projetos que não possuem retornos financeiros positivos são depreciados; 3) sua gestão se torna bastante restrita a poucos especialistas ${ }^{59}$; 4) é desconsiderada a visão dos indígenas sobre desenvolvimento. Neste contexto, o capital se apodera dos objetivos do programa, já que a obsessão pela rentabilidade financeira força a adequação de tudo e de

\footnotetext{
${ }^{59}$ Em diversos momentos, os consultores entrevistados se referiram a pessoa que seria capaz de fazer a gestão do programa como o "super-homem", literalmente. A referência ao "super-homem" nos remete a qualidades extrahumanas, além, claro, da determinação de um sexo específico, o masculino.
} 
todos à lógica do mercado, em que o desempenho é mensurado para que se possa medir o sucesso de qualquer empreendimento (GAULEJAC, 2007).

$\mathrm{Na}$ hora de decidir quais projetos seriam postos em funcionamento, os econômicos foram priorizados, dado que foi em termos empresariais que a COPEL delimitou o programa, como observado por Carlos (consultor do programa na área de Agronomia). Apesar do engenheiro que liderou a criação do TR ter sido afastado do processo antes mesmo do início dos diagnósticos, sua presença pode ser sentida durante todo o processo ("estava lá a marca do cartesianismo do engenheiro").

Assim, mesmo que os consultores estivessem entendendo o programa sob outra perspectiva, a forma como foi feito o TR o enrijeceu, pois os objetivos passaram a ser essencialmente econômicos e não especificamente ligados aos interesses dos indígenas o que, em muitos casos, não incluía nem o Programa de Desenvolvimento, como veremos adiante.

Durante as entrevistas ouvi relatos sobre os pedidos dos índios para a instalação de uma pequena fábrica de fraldas na aldeia. A ideia dos índios era suprir uma necessidade da comunidade por fraldas infantis, já que uma parcela considerável dela era formada por crianças ${ }^{60}$. Entretanto, a fábrica foi barrada pelos consultores por ter sido considerada economicamente inviável e seria melhor cada um comprar as fraldas no mercado. Fábio se lembra bem da resposta dada pelos consultores que fizeram o levantamento da viabilidade econômica: "Fábrica de fralda? Não, não dá, é muito caro, melhor vocês comprarem a fralda".

Aos olhos dos "brancos", talvez a fábrica de fraldas seja mesmo inviável, sendo preferível que os índios adquirissem-nas no mercado. Sua visão é forjada na lógica econômica de não-indíos. Entretanto, o que eles ignoraram era que os índios não estavam pensando desta forma economicista e materialista, mas comunitária. Em nenhum momento passou pela cabeça deles vender as fraldas e concorrer com a Johnson \& Johnson, como entendia um dos consultores que achou o projeto inviável:

\footnotetext{
${ }^{60}$ Como cerca de $50 \%$ dos moradores é formada por jovens de até 18 anos, sendo mais da metade composta por crianças de até 11 anos, conforme levantamento feito pelos consultores da area de economia durante o diagnóstico (PROGRAMA DE SUSTENTABILIDADE SOCIOAMBIENTAL DA TERRA INDÍGENA APUCARANINHA, 2011a), o uso de fraldas é bastante grande.
} 
Então, não adianta colocar uma fábrica de fraldas lá dentro. Não adianta que eles vão concorrer com a Johnson \& Johnson, entende? Eles vão produzir lá e vão vender. Eles vão pro mercado com a Johnsons e Johnsons e o custo é muito menor do que nós aqui. Nós não temos escala, entende? Então, isso pela conjuntura (Alberto, consultor do programa na área de Administração).

Pelo contrário, a ideia principal era distribuir aos que precisam dela na aldeia. Os Kaingang ainda preservam a ideia de comunidade, em que as formas de produção se dão a partir da ideia de subsistência de todos. Não da subsistência para a sobrevivência, como é entendida na lógica dos "brancos", mas nos moldes de uma vida digna (LUCIANO, 2006). Para o kaingang, é inadmissível ele ter o que comer e outros passarem fome. Nas nossas conversas, várias vezes falaram sobre dificuldades pelas quais já passaram na aldeia, mas nenhum deles fez referência à fome, já que é bastante comum a divisão dos alimentos entre as famílias, como se lembra João:

Por exemplo, se você tiver hoje com 10 mil, 20 mil, essa semana já torra tudo. Comprar algumas coisas ali. A gente gosta mais de carne de porco, né. Comprar uns 2 ou 3. Chamar os parentes pra comer. Porque nós, os indígenas, não têm costume de comer só a mulher e o homem. Nós chamamos tudo as parentada pra comer tudo mundo. (João, kaingang da TI Apucaraninha)

Sua fala evidencia o quanto as relações sociais com os parentes ${ }^{61}$ são mais importantes do que as relações econômicas. Tradicionalmente o fruto do trabalho do índio não podia ser apropriado só por ele, tendo "as relações de parentesco [..] um papel decisivo na organização da forma de trabalho e da apropriação dos produtos dela derivados", aponta Veiga (2006, p. 836). Assim, os produtos colhidos e a caça, por exemplo, deviam ser divididos com os parentes. É claro que hoje muita coisa mudou, mas o costume de chamar todos os parentes

\footnotetext{
${ }^{61}$ A noção de parente para os Kaingang é diferente da dos "brancos". Parentes para eles são todos aqueles kaingang que possuem as mesmas marcas tribais, como explica João: "Quando chega pessoa estranha da aldeia aí eles falam assim, né: 'você é de onde?' Aí é de tal lugar. E aí cada um tem a marca dele, né. Marcas tribais que eles fazem, né. A minha marca é riscada assim, né. Depois tem uns que é redondo também, né. Aí eles perguntam: 'qual que é a tua marca?' Aí ele: 'ah, então você é meu parente'. Porque todas as aldeias que está em Kaingang tem as marcas deles, né. Se a minha marca riscada e eu for lá pra Guarapuava, aquelas aldeias ali, eles perguntam: 'você é de onde?' 'Sou de tal lugar'. 'Mas que marca você é?' Eles falam que você é parente então". De forma mais ampla, o termo parente também pode se referir a todos os índios, independente de marca ou etnia, servindo, então, marcador de uma identidade indígena uma vez que compartilham alguns interesses e histórias comuns, como é descrito por Luciano (2006).
} 
para comer junto me parece um resquício da prática tradicional de dividir os alimentos, mesmo que não haja mais esta obrigação social.

Góes (2014) ao relatar a economia da TI Apucaraninha para outro programa compensatório, o PBA, Projeto Básico Ambiental, implantado em oito terras indígenas Kaingang no Paraná como indenização pela construção e operação da Usina Hidrelétrica de Mauá, se mostra preocupado quando se refere à tentativa de do Programa de Sustentabilidade Apucaraninha em agregar à economia do parentesco uma economia de mercado.

Em Apucaraninha, as lavouras coletivas financiadas pelo fundo criado a partir de um processo indenizatório gerido pela comunidade e pela COPEL, que teriam orientação comercial, via de regra são consumidas no interior da TI e por parentes de outras TI's. Em lugar de comercializar a produção para repor as divisas retiradas do fundo, as lideranças optam por distribuir o alimento produzido entre os parentes, o que de uma perspectiva econômica de acumulação torna o processo "insustentável”. Assim, o que está em jogo é a confluência de uma perspectiva econômica de distribuição, baseada nos laços de parentesco indígena, e outra perspectiva econômica de acumulação, própria da forma ocidental, onde o que importa é o lucro advindo das trocas comerciais, independentes das pessoas e das relações que a efetivam (GÓES, 2014, p. 57).

Para os "brancos", acostumados com a perspectiva econômica de acumulação, distribuir os produtos colhidos para a comunidade não é racional, uma vez que o "valor perdido" impactará negativamente no resultado final do fundo. Para que o programa de desenvolvimento se torne economicamente sustentável, é preciso que os índios deixem de lado a perspectiva de distribuição e se associem, de uma vez por todas, à perspectiva econômica de acumulação e, portanto, à ideia de desenvolvimento econômico.

A inevitabilidade do mercado capitalista está nas falas de alguns dos consultores do Programa de Sustentabilidade de Apucaraninha que se utilizam da oposição entre o que eles consideram uma vida precária, marcada pela pobreza, e uma vida digna e autônoma proporcionada pela produção econômica para o mercado. O que pude extrair dos discursos de todos os "brancos" que trabalham ou trabalharam para o programa foi a preocupação com o desenvolvimento econômico da aldeia por meio da sua inserção no mercado. 
Enquanto os "brancos" envolvidos com o programa de desenvolvimento se preocupavam basicamente com a vitalidade econômica dos projetos e o seu alinhamento ao mercado, os índios desejavam prover sua subsistência material e cultural internamente, sem se preocupar com a produção de excedente para venda e, tampouco, com o custo da manutenção de seus aspectos socioculturais.

É interessante notar que ambos são impulsionados pela autonomia, mesmo que para cada grupo haja profundas diferenças conceituais sobre este termo. Para os "brancos", a autonomia está no desenvolvimento econômico da comunidade indígena. Acreditam, portanto, que a sua ligação com o mercado permitiria o seu empoderamento e a sua autossustentabilidade. Assim, dão ênfase aos resultados, à eficácia, ao progresso e ao desenvolvimento como meta a alcançar, ao planejamento e à gestão, temas conexos ao mundo das empresas. Em contrapartida, para os índios, de forma geral, a autonomia parece estar ligada mais à autodeterminação, incluindo assim a "garantia dos direitos elementares à vida e à liberdade, aos quais está ligada a sobrevivência do grupo como tal”, afirma Perrot (2008, p. 225).

A lógica que rege estes programas de desenvolvimento é quase inevitavelmente a mesma do sistema capitalista, dado que "se [os indígenas] pretenderem desenvolvimento, têm que aceitar e se sujeitar à lógica do sistema, ou seja, do mercado. Do contrário, estarão condenados ao fracasso, ao atraso à "não-civilização", lembra Luciano (2006, p. 199). Tornando o desenvolvimento econômico algo inevitável e natural para o bem-estar da comunidade, reduzindo todas as outras instâncias da vida humana à dimensão econômica, banindo, assim, as formas tradicionais de produção e distribuição territorial "associadas a valores morais e espirituais", as substituindo por outros valores que "privilegiam a competição, a concorrência, a ganância [e] o lucro a qualquer custo" (LUCIANO, 2006, p. 199).

A justificativa, como sempre, está no bem-estar da comunidade. Eu até acredito que os participantes do programa em Apucaraninha estejam mesmo preocupados com o bem-estar da comunidade e, portanto, projetam um futuro melhor para eles. Mas, a que bases? Alguém, aliás, se lembrou de perguntar aos índios o que isso significa para eles? Será que os índios têm a mesmas concepções de bem-estar dos "brancos"? De acordo com alguns estudos da antropologia, não. Luciano (2006) lembra que os índios, ao serem perguntados sobre o esperam da vida, respondem "viver bem", o que significa viver em equilíbrio comunitário 
com os que estão ao seu redor, como familiares, membros da comunidade e natureza. Nada parecido com a concepção utilitarista dos "brancos".

Assim, por mais que os índios hoje pensem e ajam muitas vezes conforme os costumes dos "brancos", isso não significa que toda a sua vida se baseia nos termos da sociedade envolvente. É claro que por estarem inseridos em uma sociedade mais ampla, dominada pelos costumes e regras dos não-índios - e onde a força econômica faz uma pressão quase irresistível - aprenderam a utilizar os símbolos dos "brancos".

Numa relação simbiótica apropriam-se ou são obrigadas a utilizar conjuntos simbólicos, políticos e ideológicos produzidos externamente, já que suas noções, culturalmente fundamentadas, não são sequer compreendidas ou consideradas válidas no âmbito do sistema mais amplo que as incorpora (ARRUDA, 2001, p. 49).

Os índios Cinta Larga do Amazonas, apesar de não valorizarem o dinheiro como os "brancos", aprenderam rapidamente que é por meio dele que podem suprir suas necessidades de segurança (alimentar, de moradia e de bens manufaturados). Afinal, coisas que para os índios não têm valor monetário, como os minérios e a madeira - "diamante é para eles apenas pedra; tora, apenas árvore”, lembra Azanha (2011, p. 543) - são valorizadas na sociedade envolvente, pelas quais pagam um bom dinheiro, mesmo que ainda seja infinitamente menor do que esses produtos valham no mercado.

Entretanto, apesar de terem sido forçados a aprender a lógica capitalista, os Cinta Larga não tratam o dinheiro como um fim em si mesmo, mas como um meio para adquirir o que o mercado capitalista os fez desejar. Não desejam, portanto, o dinheiro, mas os produtos que são capazes de comprar com ele. É assim que eles não costumam poupar dinheiro, gastando tudo o que recebem rapidamente. Os Cinta Larga possuem a mesma relação com o dinheiro que os Kaingang, como apontado por Tommasino (1995, p. 291): “de forma absolutamente contrária ao estabelecido pela lógica do mercado capitalista".

Desta forma, longe de significar um processo de aculturação, os indígenas remodelaram sua cultura a partir da relação entre seus costumes e valores tradicionais com a cultura capitalista da sociedade envolvente. Para Arruda (2001, p. 50), “os povos submetidos às pressões da 
expansão capitalista sofrem mudanças radicais, induzidas por forças externas, mas sempre orquestradas de modo nativo". É assim que desejam plantar soja ou criar gado conforme seus vizinhos "brancos", mas não admitem que essas atividades sejam praticadas em espaços coletivos que devem dividir com índios de outras facções, como veremos logo adiante.

Ao mesclarem - ou serem obrigados a mesclar, se assim o preferir - aspectos da cultura indígena tradicional com a cultura moderna do "brancos" os índios estão construíndo um nova visão de mundo, nem subordinada à "branca", nem puramente índia. É isso que a maior parte dos participantes "brancos" do Programa de Desenvolvimento Sustentável de Apucaraninha não conseguiu enxergar.

Assim, apesar da "boa vontade" dos participantes do programa, eles não conseguiram se livrar dos mesmos erros cometidos em épocas passadas: a não participação efetiva dos indígenas. As ações dos "brancos" continuam sendo a de assimilação dos índios à sociedade capitalista. Como disse um dia Terena (2000, p. 166), “em todo planejamento, execução e administração dos bens indígenas lhes é negada a participação mínima, sequer por uma questão de elegância e quase sempre, quando ocorre, por uma demagogia politiqueira”. Mesmo quando o discurso da participação parece central nas falas dos consultores e dos outros participantes "brancos" do programa, a mesma sistemática dos projetos anteriores foi mantida. O resultado disso é que, na visão dos "brancos", passados alguns anos, os projetos ainda caminham a passos lentos. Daí que, como aponta Matos (2007, p. 21), ainda hoje "as expectativas dos agentes financiadores e das organizações e comunidades indígenas quanto ao resultado desses projetos nem sempre conseguem ser atendidas ou efetivadas na realidade".

Mais uma vez os envolvidos com esses projetos dão como razões para o desencontro entre o desejado, o planejado e o executado, a falta de comprometimento dos índios e sua pouca capacitação e habilidade para lidar com as questões relacionadas aos projetos, negligenciando o domínio e a indiferença dos "brancos" sobre os índios. A falta de comprometimento dos índios de Apucaraninha é a razão apontada por muitos dos envolvidos com o programa para os problemas enfrentados, como pode ser visto no recorte abaixo:

A ideia é justamente essa: é que eles façam a própria gestão de uma maneira autossustentável. Mas a gente, por alguma razão, não vê esse próprio engajamento. Não vê essa identificação deles com nenhum dos programas. 
Eu estou otimista em relação a isso. Eu penso que a gente tentando descobrir onde que está falhando o programa. Porque, me parece, que não é uma falha de concepção do programa. É essa a leitura que eu vejo. Não é uma falha de concepção. Ele é um programa muito bem estudado, muito bem feito, muito bem detalhado. Me parece que é uma questão de identidade realmente. Falta eles comprarem a ideia de que o programa vai trazer frutos pra eles. [...] Eu acho que a gente tentando trabalhar nessa questão, o programa pode ser muito, muito proveitoso. Sem fazer altas modificações, porque como eu the disse, eu vejo que ele foi bem concebido. Não sei por que não colou ainda para eles as ideias. (Luciano, MPF)

A resposta para o "fracasso" do programa está, na visão de Luciano, na não identificação do índio. Assim, apesar do programa ter sido bem concebido ("ele é um programa muito bem estudado, muito bem feito, muito bem detalhado"), os indígenas ainda não compreenderam o seu potencial para melhorar suas vidas ("não colou ainda para eles as ideias"). Não passa pela cabeça de Luciano que a causa da não identificação dos indígenas com o programa está na forma como o programa foi concebido e desenvolvido: de fora para dentro, sem a efetiva participação dos indígenas e, como fui avisada pelos consultores, sem a aprovação dos indígenas, já que ouvir os índios é bem diferente de compreender suas necessidades. Tanto que ele não vislumbra grandes mudanças no programa. Afinal, para ele, o problema está no índio e não no programa. E Luciano ainda está otimista, pois ele acredita que corrigindo a sua única falha, o não engajamento dos indígenas, o programa irá funcionar como o planejado, como se essa fosse uma falha simples, um parafuso solto que basta apertar.

Para Matos (2007), o problema é que a participação para a elaboração dos projetos não tem garantido um diálogo efetivo entre universos de significados culturais diferentes, uma vez que o discurso hegemônico dos "brancos" compromete a "fusão de horizontes" nesta relação interétnica. Mesmo quando os não-índios se mostram aderentes à ideia de democracia participativa, as dificuldades no diálogo interétnico aparecem na intolerância com formas de vida daqueles que se "distanciam dos parâmetros culturais do pólo dominante da sociedade global" (OLIVEIRA, 2001, p. 251).

Da mesma forma que os índios não viam os projetos da Funai nas roças coletivas como seus porque foram impostos a eles (TOMMASINO, 1995), como já apontado anteriormente, o 
Programa de Desenvolvimento em Apucaraninha parece sofrer do mesmo problema, já que para os Kaingang o projeto é da COPEL, como ouvi diversas vezes deles. Neste caso, como eles não se veem como partes do processo não faz sentido pedir a sua participação. $\mathrm{Na}$ verdade, até mesmo o conceito de participação é estranho ao olhar indígena: participar é tomar parte em eventos externos; quando os eventos são deles, eles os realizam, como explica Little (2006, p. 38, grifos do autor):

\begin{abstract}
A realização da agência étnica do grupo é diferente de mero processo de participação. Quando há situações verdadeiras de agenciamento ("agir como sujeitos"), não tem muito sentido falar em participação, já que o termo participação aplica-se mais a situações nas quais as pessoam tomam parte em eventos ou programas organizados externamente. Um exemplo pode esclarecer esse ponto: não seria muito apropriado dizer que "os índios xinguanos participaram do Quarup"; mais adequado seria dizer que os “índios xinguanos realizaram o Quarup". Caso jornalistas, turistas ou antropólogos forem convidados a assistir o rito, eles teriam uma "participação" porque eles "tomaram parte" de um evento que foi idealizado e realizado por outro grupo.
\end{abstract}

Com relação à participação social, Stone (1989) já criticava a aplicação desta ideia em contextos em que os participantes dos programas têm uma concepção diferente sobre o seu significado. Esse fenômeno, observado por Stone (1989) em comunidades no Nepal, foi visto no Brasil por Lima (2004) quando da implantação do PPTAL, Projeto Integrado de Proteção às Populações e Terras Indígenas da Amazônia Legal, desenvolvido e implantado pelo governo brasileiro em parceria com organizações internacionais e agências internacionais de cooperação.

No PPTAL, a falta de consenso sobre o que significava participação e como ela deveria ser implementada levou a uma construção discursiva baseada no que os "brancos" imaginavam ser os sujeitos do programa (os índios, que em muitos programas, inclusive no PPTAL, são nomeados como "beneficiários") e, ainda, sobre qual a melhor forma de concretizá-la, lembra Lima (2004). Assim, apesar das boas intenções de algumas pessoas, que defendem e tentam criar mecanismos de participação dos índios, a relação entre eles está comprometida pelas regras do discurso hegemônico que impede a tolerância com o modo de ser do outro (OLIVEIRA, 2006). 
Por exemplo, na maior parte das vezes, os "brancos" envolvidos nos projetos ignoram os diferentes conceitos nas comunidades indígenas atribuídos a algumas palavras utilizadas pelos "brancos", como participação e coletivo. A noção de coletivo dos Kaingang dificilmente é bem compreendida pelos não-índios. Pela lógica dos "brancos", ao se falar em coletivo, temse a sensação de os espaços comuns serão divididos por todos os que vivem em uma determinada comunidade, em uma espécie de socialismo.

Entretanto, há um componente bastante importante na lógica das sociedades indígenas: o faccionalismo. As comunidades Kaingang são formadas por facções, grupos suprafamiliares, marcadas pela união política de diferentes casas (famílias extensas ligadas pela relação entre genros e sogros). Assim, uma facção se nega a trabalhar com a outra.

Como alerta Schröder (2003), entre os indígenas, o trabalho coletivo não implica uma mentalidade de cooperativismo. É desta forma que os índios de Apucaraninha vislumbram a criação de gado e a roça separada por facções. Forma esta considerada economicamente inviável pelos consultores do projeto, que não conseguiram compreender que as atividades que eles propunham esbarram no faccionalismo kaingang, como podemos ver na fala de Carlos:

Muitas vezes, quando os projetos são projetos direcionados para a comunidade como um todo, existe uma situação de gerenciamento interno que são os grupos familiares. As coisas não são distribuídas de forma equilibrada. Então, o Cacique vai estabelecer para o projeto aqueles que são do seu grupo. É assim que funciona, certo? E aí você passa a ter essa condição. Eu vou montar a produção de boi. Então vamos instalar produção de bovinos. Quem vai cuidar do boi? "Eu não vou cuidar do boi para o cara que não é da minha família. Se eu tiver que cuidar vai ser do meu boi, do meu grupo familiar". Aí cada um quer ter o seu pedacinho com duas cabeças de boi lá dentro. Não há sistema tecnificado que aguente. Aí o que que acontece? Se você tem 300 cabeças de gado em um pasto, eles estão se reproduzindo em uma velocidade muito maior do que você colocar o boi e a vaca em um canto do quintal, certo? Mas do meu eu cuido. Eu não vou cuidar do que não é do meu parente, do meu grupo familiar, do meu sistema de hierarquia dentro da comunidade. Não há um gerenciamento contínuo 
porque isso está diretamente ligado ao sistema do cacicado. Cada um quer marcar o seu boi. Você teria que construir milhares de cerca, entendeu? Você tem que comprar tantas seringas. (Carlos, consultor do programa na área de Agronomia)

Há na fala de Carlos uma oposição entre o modo de produção tradicional dos indígenas e o modo de produção moderno, representada pelos aspectos interdiscursivos "grupo familiar" versus "gerenciamento", "baixa produtividade" (implícito subentendido) versus "alta produtividade" (implícito subentendido), "sistema arcaico" (implícito subentendido) versus "sistema tecnifico" e "alto custo de produção" (implícito subentendido) versus "menores custos de produção" (implícito subentendido).

Ao tomar como ponto de partida do seu argumento a superioridade do modo moderno e racional frente ao tradicionalismo, Carlos legitima a assimilação indígena, da mesma forma que sempre fez o Estado moderno (BAUMAN, 1999). Assim, defende a produção tecnificada, mesmo sabendo que ela passa por cima do modo de vida dos Kaingang. A justificativa para isso é que, se não fosse assim, a produção não seria viável economicamente.

Essa mentalidade não é exclusiva de Carlos, já que a intolerância com a "existência não ordenada", diz Bauman (1999), é intrínseca à modernidade. Foi em busca da ordem, corolária da razão, que o homem moderno buscou formas de controlar a natureza. Dominar a natureza para o desenvolvimento da humanidade se tornou, então, o fundamento da civilização moderna. Um ideário "universal" calculado tendo por base o que é considerado lógico e, portanto, racional, pelo europeu ${ }^{62}$, "burguês, branco e masculino" (GONÇALVES, 2002, p. 218).

O ser racional é aquele que utiliza o conhecimento, o saber, para dominar a natureza. Trata-se, portanto da integração da razão teórica com a razão prática. A primeira sendo o meio e a segunda o fim. O problema é que, na visão de Descartes, que sustenta o pensamento ocidental moderno, não há espaço para nenhum conhecimento que não seja o de caráter matematizante, afirma Silva (1997). Assim, todos os domínios da vida, da física à moral, passam a ser quantificáveis, porque esse é a único modo da razão ser produtiva. Para Silva (1997), essa

\footnotetext{
${ }^{62}$ Huenemann (2012) escreve que os grandes pensadores do iluminismo, acreditando na habilidade humana para a razão, acabaram produzindo não seres racionais, mas bons europeus.
} 
unidade da razão leva a formação de um único sentido para o progresso, restringindo a própria racionalidade.

\begin{abstract}
Ora, uma vez este modelo estabelecido, as coordenadas fundamentais do conhecimento estão definitivamente postas, uma vez que será este modelo que propiciará precisamente o progresso, já que ele é visto como único que pode permitir o acesso à evidência teórica. O sentido último do progresso é a máxima expansão deste modelo (SILVA, 1997, p. 12).
\end{abstract}

A filosofia cartesiana, ao despir a natureza do seu valor de uso, permite, posteriormente, que ela seja tomada simplesmente pelo seu valor de troca. Assim, a única "relação" aceitável do homem com a natureza deve ser sempre com bases utilitárias. Ao mobilizar toda a sociedade, a torna homogênea, uma sociedade administrada em que o grande interesse passa a ser suprir as necessidades materiais e intelectuais. "O julgamento das necessidades e sua satisfação [...] envolve padrões de prioridade - padrões que se referem ao desenvolvimento ótimo do indivíduo [...] sob a ótima utilização dos recursos materiais e intelectuais à disposição do homem" (MARCUSE, 1973, p. 27).

Como nos avisa Bauman (1999), o conceito de natureza aqui engloba tudo aquilo que compromete a harmonia social ou econômica, que não tem utilidade aparente, que não tem propósito, como um rio que, inavertidamente, corre para o lado errado, plantas indesejadas que crescem no jardim e, até, pessoas que são consideradas desviantes no sistema, ou seja, "os inadaptáveis, os incontroláveis, os incongruentes e ambivalentes”, aponta Bauman (1999, p. 47). Em suma, "qualquer coisa que compromete a ordem, a harmonia, o plano, rejeitando assim um propósito e significado, é Natureza. E sendo Natureza, deve ser tratada como tal” (BAUMAN, 1999, p. 48).

Apesar das críticas à ideologia iluminista do progresso, ela continua entre nós, firme e forte, ainda que reformulada, o impondo, mesmo que pela força, como o único caminho para o avanço da humanidade. "Nesse aspecto e no interesse pessoal que ele disfarça a atual ideologia do progresso muito se assemelha aos projetos missionários dos impérios passados" (WRIGHT, 2007, p. 19). 
Para Díaz-Polanco (2006), a completa ausência do Outro no projeto universalizante, é explicada pelo desejo utópico dos modernos de suprimir a diversidade cultural, considerando visões distintas das suas uma condição imperfeita no processo de evolução. Desta forma, sociedades que teimam em viver em outras bases, ou seja, colocando outras racionalidades acima da racionalidade utilitária, são vistas como irracionais e, portanto, devem ser dominadas. Isso justifica o domínio de qualquer sociedade que viva sob outras lógicas que, por não serem as definidas como racionais pelos europeus, são consideradas "selvagens".

A tradição liberal "fala de direito à liberdade, inclusive para que um homem possa oprimir e explorar outro homem em nome do progresso e da livre iniciativa”, lembra Gonçalves (2006, p. 97). O oprimido o é, justifica-se, em nome do progresso, para que seja retirado do seu estado de selvageria. É que a construção da ordem exige que aquele que não se encaixe nos parâmetros definidos seja "dominado, subordinado, remodelado de forma a reajustar às necessidades humanas" (BAUMAN, 1999, p. 15, grifo do autor).

Derrubando os empecilhos ao progresso se institui uma hierarquia de dominantes e dominados. São dominantes os homens-europeus-burgueses-brancos, e dominados os que possuem uma "natureza selvagem" como as mulheres, os operários, os indígenas, os camponeses e outros povos que se constituíram com uma outra lógica social (GONÇALVES, 2006). Para Ribeiro (2012, p. 214), “essa hierarquia é instrumental para fazer crer na existência de um ponto que pode ser atingido caso se siga um tipo de receita mantida [por aqueles] que lideram a 'corrida' para um futuro melhor'.

É por isso que uma das entrevistadas, Elisa, afirma que a maior parte dos consultores foi a campo não disposta a olhar para o índio, simplesmente porque carrega a ideia de que ele é a representação do atraso. Ou seja, para ela, estes consultores foram arrogantes, uma vez que assumiram sua superioridade intelectual frente ao índio, atribuindo a eles mesmos privilégio sobre o conhecimento dos Kaingang.

Eu vi que a maioria não absorveu, eles são impermeáveis. Impermeáveis por quê? Porque eles se acham os donos e sabem tudo. Sabem o que é bom pro índio, sem conhecer, mas eles acham que sabem o que é bom pro índio, porque o índio está errado. Então eles não prestaram atenção, não ouviram e não assimilaram. (Elisa, antropóloga, treinamento dos consultores) 
Um dos entrevistados chegou até a comparar a dificuldade de impor o conceito de sustentabilidade aos indígenas com uma "luta árdua". A escolha do léxico "luta" ressalta o seu sacrifício pessoal ("nós fizemos várias oficinas lá com eles" e "grande desafio") no combate aos desvios à ordem social e econômica:

Então, na verdade, foi uma luta árdua. Nós fizemos várias oficinas lá com eles para mostrar, primeiro assim, o que é sustentabilidade. Vem do conceito da palavra. O que os índios vão entender sobre sustentabilidade? O que é para nós? O que seria para os pesquisadores a palavra sustentabilidade? Então, já começou um grande desafio, explicar o que seria isso pra eles. Dentro daquele contexto, o que aquele recurso poderia trazer. (Alberto, consultor do programa na área de Administração)

Apesar de sugerir que as oficinas foram utilizadas para promover o diálogo entre os participantes do projeto, "brancos" e índios, o que transparece na fala de Alberto é que elas foram utilizadas para doutrinar os índios ("para mostrar, primeiro assim, o que é sustentabilidade" e "explicar o que seria isso pra eles") disseminando um pensamento unidimensional. A produção desta sociedade unidimensional é uma forma de dominação, avisa Marcuse (1973, p. 28), visto que ao impor uma só racionalidade, cria falsas necessidades e sufoca as "necessidades que exigem libertação".

É assim que se dissemina "a necessidade irresistível para a produção e o consumo do desperdício [e] a necessidade de trabalho estupefaciente onde não mais existe necessidade real" e se desvalorizam as liberdades individuais (MARCUSE, 1973, p. 28). Aliás, a própria liberdade é transformada em mecanismo de controle, ao se definir o que pode ser escolhido e o que é escolhido pelas pessoas.

O pensamento unidimensional é promovido para toda sociedade por meio dos operadores da política e "seus provisionadores de informação" (MARCUSE, 1973, p. 34), como a mídia, o mercado e, principalmente, a ciência moderna. Segundo Faria e Meneghetti (2005, p. 5), “a perda da capacidade questionadora da nova realidade criada pelos avanços científicos alimenta a cisão da neutralidade da ciência”. Desta forma, a própria sociedade não permite 
comportamentos oposicionistas, disseminando a noção de que as ideias contra hegemônicas são ilusórias ou sem qualquer sentido.

Foi com base na ideologia do progresso racional que surgiu a teoria da modernização. Os teóricos da modernização, entre eles Daniel Lerner (1958), retomaram as ideias evolutivas do progresso, sendo o processo de modernização uma escala entre um padrão atrasado e um avançado, este baseado no modelo europeu e norte-americano. O ponto de partida era o atraso econômico e social para o qual o único remédio era o crescimento econômico. Para Stavenhagen (1984, p. 14):

\begin{abstract}
Pratica-se muito, neste período, o exercício de identificar os chamados obstáculos à mudança: instituições sociais tradicionais, economia não monetária, ausência de espírito empreendedor, visão de mundo particularista e não universalista, e assim por diante. O crescimento e o desenvolvimento deveriam ser alcançados através da introdução de inovações e de uma mudança cultural adequadamente dirigida. Dizia-se que muitos países, dada uma base mínima de tamanho e recursos, poderiam deslanchar um crescimento auto-sustentado, sob certas condições que os técnicos e a comunidade internacional deveriam fornecer. Os países subdesenvolvidos eram tidos como sociedades duais, nas quais um setor moderno e progressista chocava-se com outro, tradicional e atrasado, e este último deveria ser ultrapassado.
\end{abstract}

Não por coincidência que no Brasil que surge como nação, principalmente após a década de 1930, busca-se construir um país conforme imaginado pelas elites: civilizado e moderno (COSTA; SUZUKI, 2012). Nesse processo, o povo se tornou instrumento e não protagonista, sendo a construção concreta do Brasil resultado de uma realidade imaginada, baseado no planejamento para a modernização ${ }^{63}$.

Nas teorias do desenvolvimento busca-se a homogeneidade e não a diversidade, uma vez que o conceito de desenvolvimento está carregado de uma visão de mundo particular: o da “história das nações industrializadas" (PERROT, 2008, p. 222). O diverso, aqui, é

\footnotetext{
${ }^{63}$ Entre as décadas de 1930 e 1980 o processo de reordenação territorial e de desenvolvimento se dá capitaneado pelo Estado desenvolvimentista. Na década de 1990, com a Reforma do Estado, passam a ser geridos pelo poder hegemônico do empresariado em aliança com o poder local, afirma Rückert (2005). Vainer (2007) chama este fenômeno de privatização dos processos de planejamento e controle territorial.
} 
reproduzido dentro do signo da uniformidade do sistema, produzindo o que Díaz-Polanco (2006) chama de etnofagia, a domesticação da diversidade étnica pelos parâmetros das sociedades capitalistas. Assim, mesmo que o desenvolvimento seja renomeado e tratado como uma nova forma - "etnodesenvolvimento" e "desenvolvimento sustentável "64" - estará sempre atrelado à ideia de progresso, de comparação entre "bom" e "mau" desenvolvimento, de um modelo cultural, social e econômico pré-definido que não admite desvios e, portanto, não aceita modos de vida diferentes ao que não seja considerado racional e econômico.

Neste ponto de vista funcional-estrutural do desenvolvimento, há pouco
lugar para os grupos étnicos. Eles são descartados como emissários do
passado, como obstáculos à modernização. Aqui, mais uma vez, o
pertencimento étnico é considerado não racional, tradicional e até
conservador (STAVENHAGEN, 1984, p. 27).

Compreende-se, portanto, porque a questão étnica nunca foi devidamente incorporada nas teorias do desenvolvimento. Em toda a história de contato entre os "brancos" e os indígenas brasileiros, estes nunca foram considerados sujeitos de seu desenvolvimento. Ainda hoje, com relação ao índio subsiste a ideia de que ele é um sujeito transitório, em vias de assimilação, ou seja, de se modernizar, sendo "os seus modos de vida e de pensar, especialmente no que diz respeito as suas formas de produção econômica, tantas vezes qualificadas como 'economias da miséria"”, como defende Gallois (2005).

Para Escobar (1995), o desenvolvimento é um discurso, disseminando imagens, linguagens e técnicas que impõe formas de organizar a vida social conforme o status quo. Trata-se de um

\footnotetext{
${ }^{64}$ Vizeu, Meneghetti e Seifert (2012) apontam as contradições do conceito de desenvolvimento sustentável dominante quando o confrontamos com o sistema de produção capitalista que, por ser totalitário, organiza a vida em sociedade, não permitindo questionamentos sobre suas próprias contradições. É desta forma que, ao criarem o conceito de desenvolvimento sustentável para dar conta das contradições do próprio sistema em que está inserido, foram ignorados aspectos centrais que, assim, não permitem o seu funcionamento efetivo. Assim, não levaram em conta que não limitar o desenvolvimento econômico e o crescimento das organizações, reprimindo o consumo, torna o conceito uma impossibilidade (VIZEU; MENEGHETTI; SEIFERT, 2012). Do ponto de vista da economia neoclássica não há limites para o uso dos recursos já que o progresso científico/tecnológico aumenta a eficiência na sua utilização, garantindo a perpetuação do crescimento econômico. Para Romeiro (2012, p.74), "a economia funciona num mundo onde não existe a segunda lei da termodinâmica, a Lei da Entropia". Assim, o conceito de sustentabilidade está ancorado em uma premissa falsa de que conforme um recurso vai se exaurindo a ciência encontrará um substituto, garantindo a sustentabilidade do crescimento econômico.
} 
discurso de poder, uma vez que, em nome da guerra contra a pobreza ${ }^{65}$, foram formulados modelos e teorias que prometiam a superação do atraso em que supostamente viviam as comunidades e países considerados subdesenvolvidos, contanto que eles se submetessem ao planejamento social determinado.

Assim, fazem isso, despolitizando suas ações enquanto os tecnificam. Ferguson (2006, p. 273, tradução minha) afirma que esse é o objetivo dos programas de desenvolvimento, na medida em que "o aparato do desenvolvimento [...] não é uma máquina que visa eliminar a pobreza, [...] mas uma máquina que reforça e expande o exercício de poder". O fenômeno da pobreza é, assim, desligado dos seus aspectos sócio-históricos. O que resta, portanto, deve ser gerido tecnicamente. Reduzindo a questão da pobreza a problemas técnicos que, assim demandam soluções técnicas, o desenvolvimento a despolitiza, se tornando, nas palavras de Ferguson (2006), uma máquina de antipolítica que, como uma máquina antigravitacional da ficção científica, suspende os aspectos politicos fazendo política.

Ribeiro (2012, p. 220) lembra que a "o planejamento é o coração da iniciativa racional de desenvolvimento". A lógica está na ideia de que para que o desenvolvimento seja alcançado, é necessário impor regras, controlando tempo, pessoas e recursos. No entanto, regras dependem de aceitação, sem a qual o projeto não terá sucesso. Assim, torna-se parte do planejamento racional a disseminação de uma mesma racionalidade no território em que o projeto está sendo implantado. Para Ribeiro (2012, p. 221), é intrínseco aos projetos de desenvolvimento impor mudanças, ou seja, "é certo que 'transformação' é o núcleo duro do desenvolvimento enquanto ideologia". Mas é mais certo ainda que essa transformação não opera fora das assimetrias de poder.

"Dramas desenvolvimentistas" são tipos complexos de encontros que juntam
atores e instituições locais a outsiders. O fato de outsiders pretenderem
planejar o futuro de uma comunidade é indicativo do seu poder diferencial
no encontro. Em tais circunstâncias, instala-se uma dicotomia. Por um lado,
há os objetivos e racionalidades dos planejadores; por outro lado, o destino e
a cultura das comunidades. Antes da existência de um projeto de

${ }^{65}$ Este argumento, sustentado e disseminado por organições internacionais como o Banco Mundial, acaba por se apoiar em uma concepção etnocêntrica pela qual a pobreza é vista, de forma simplista, como o contrário da riqueza, concebida aqui como sinônimo do acúmulo de bens, confrontando diretamente a forma com que se vive nas aldeias, avisa Oliveira Filho (2000). 
desenvolvimento, populações locais dificilmente poderiam conceber que seu destino era suscetível de ser sequestrado por um grupo organizado de pessoas. Planejamento - isto é, a determinação antecipada de como uma certa realidade será - implica a apropriação, por parte de outsiders, do poder das populações locais de serem sujeitas dos seus próprios destinos. De sujeitas de suas próprias vidas, essas populações se tornam sujeitas a elites técnicas prescientes (RIBEIRO, 2012, p. 222).

O problema é que os "brancos" se acostumaram a pensar a questão indígena como um espaço secundário atrás dos aspectos econômicos, defende Arruda (2001). Na fala de grande parte dos "brancos" participantes do programa fica clara a importância dada aos aspectos econômicos, já que fazem constante referência a recursos financeiros - "o que aquele recurso poderia trazer" (Alberto, consultor do programa na área de Administração).

Assim, qualquer ação externa capitalista em suas terras é justificada tendo como referência a redução da pobreza ou a promoção do desenvolvimento das sociedades indígenas, descaracterizando o índio como sujeito e apagando as dimensões política, histórica e social e, portanto, sem chegar a compreender a raiz dos problemas.

Hoje o "argumento" do índio se submete a uma redefinição do seu significado por referência aos argumentos da "pobreza" e do "desenvolvimento econômico". Esse duplo argumento contemporâneo, apresentado em inúmeras variantes, justifica, sob a denominação "questão social", o estímulo à invasão de terras indígenas por qualquer frente de expansão da sociedade nacional que se pretenda produtora de "riquezas", ou amenizadora da "pobreza", como o garimpo, a mineração, a pecuária, projetos de colonização, de geração de energia e outros. Na realidade assim definida, o processo histórico de produção da pobreza e da desigualdade é apagado e o índio é visualizado como um entrave arcaico ao crescimento econômico, que erradicaria a pobreza, realizando a justiça social. Ou, ainda, o índio passa a ser visto como uma espécie de "latifundiário" improdutivo, ignorante, indolente e desqualificado, injustificadamente detentor da posse de vastas extensões de terras, que, se abertas ao "trabalho produtivo", supostamente resolveriam a questão da pobreza e do desenvolvimento (ARRUDA, 2001, p. 47). 
Do prisma da sociedade envolvente, a construção de uma usina hidrelétrica em terras indígenas trará indenizações e royalties suficientes para levá-los a uma situção economicamente mais confortável. O mesmo se afirma sobre o arrendamento de terras que, apesar de ilegal, ocorre sob os olhos até mesmo daqueles que têm a obrigação de vetá-las, como assume Luciano do MPF, ao dizer que elas são uma saída para aqueles que vivem em extrema pobreza. Esquece-se, no entanto, que a lógica que rege as vidas dos índios não é a mesma da sociedade envolvente.

Um caso que pode exemplificar bem esta questão é o dos Guaranis do Mato Grosso do Sul, em que foi implantado o Projeto Kaiowa-Ñandewa, de cunho estritamente econômicoprodutivo, financiado por organismos internacionais. Conforme relato de Salviani (2002), em dado momento, os índios foram chamados para participar de uma reunião com os gestores do programa para discutir aspectos relacionados à roça comunitária. No entanto, durante o encontro, os indígenas não pareceram estar interessados no assunto em pauta, "preferindo assumir uma postura lúdica e discutir assuntos particulares entre eles" (SALVIANI, 2002, p. 72). Diante deste acontecimento, os gestores do programa decidiram que não iriam mais participar de reuniões com os índios.

Pouco tempo depois, foram os índios que chamaram os gestores do programa para participar de uma reunião, assegurando que, desta vez, os assuntos seriam discutidos. Chegando ao local marcado para a reunião, os gestores viram que estavam presentes, além dos participantes do programa daquela terra indígena, lideranças de outras comunidades. $\mathrm{O}$ assunto também não era o esperado pelos gestores do projeto, pois eles discutiram um assunto que envolve a todos os índios do Mato Grosso do Sul: o tamanho das terras indígenas, o retorno dos índios que vivem fora delas e a recuperação do antigo território. Neste momento, os gestores viram que o interesse daqueles índios não era econômico-produtivo, mas sim político, sendo a recuperação de suas terras o maior objetivo, já que, para eles, com uma maior quantidade de terras, está assegurada a manutenção de seu modo de vida.

Apesar da emergência da ideia da participação democrática nos processos de planejamento, ainda é mais comum encontrar uma postura arrogante de imposição do que servirá para a superação do atraso na visão dos planejadores. Como os não-índios acreditam que são superiores, sua arrogância se expressa no desprezo e na indiferença ao modo de vida considerado atrasado, contrário à "episteme racionalista moderna acoplada à noção de 
progresso" (SEIXAS, 2015, p. 31). Assim, em nome daquilo que pensam ser o "bom planejamento", fazendo um paralelo com o pensamento de Gorz (2007), até a sociedade pode desaparecer.

Diversos envolvidos no programa demonstraram estar mais preocupados com o ajuste dos índios a um modelo de sociedade e de economia do que em compreender o seu modo de vida. Para Little (2002), o problema é que as organizações que se envolvem nestes programas não estão devidamente preparadas e, em muitos casos, nem têm interesse em lidar com o diferente.

Muitos dos entrevistados para este estudo apontaram que um dos maiores erros do programa foi não contar com pessoas realmente comprometidas com a questão indígena. Tanto entre os consultores contratados, que estavam mais preocupados com seus interesses acadêmicos e que resultassem em artigos, teses e dissertações e, ao mesmo tempo, e em cumprir as atividades para as quais tinham sido contratados - como fazer o diagnóstico, propor os projetos e entregar os relatórios - quanto entre os empregados da COPEL que se dedicavam a "amansar" os índios e, desta forma, melhorar o relacionamento deles com a COPEL. Isso fica evidente nos recortes a seguir:

Em termos de programa talvez não tenha rendido tanto. Mas, o que rendeu de dissertação de mestrado e doutorado você não faz ideia. Conhecimento gerou, né? Então, assim, faltou essa ligação maior. Muita gente entrou, talvez possa até ser leviana, mas tenha visto muito mais o seu interesse acadêmico do que o dos indígenas. Ao tentar fazer essa cola eu acho que os indígenas saíram em desvantagem. (Luciana, MPF)

O que define todo o processo é um contrato. Se você não apresentar nós vamos pôr no pau, vai para o Fórum. (Carlos, consultor do programa na área de Economia)

Bom, o resultado, em certo momento para nós, era diagnóstico, relatório e os projetos, né? Tá lá. A gente entregou o que tinha que entregar. A COPEL deu quitação do que a gente tinha que entregar. (Alberto, consultor do programa na área de Administração) 
E vi também como, eu acabo presenciando isso, como eles são abandonados por tudo. Mesmo esse programa da COPEL aqui. Claro, tem um sigilo aí, né? Mas você vê que eu acho que esse programa não é gerido de forma séria. Tudo bem, pode não dar certo porque tudo na vida pode não dar certo. Mas uma coisa é não dar certo por que não tinha que dar, não era possível, e outra por que você não se preparou de forma adequada, você não estruturou a equipe para cuidar daquilo de forma adequada e acaba não dando certo porque você largou mão, não tendo uma estrutura adequada para enfrentar o problema. Na época a COPEL optou por alguém do quadro próprio, mas não basta só pegar uma pessoa e jogar lá na aldeia. Ela até poderia supervisionar uma equipe multidisciplinar, porque, mesmo a minha participação, eu não tinha contato nenhum. Eu fui aprender muita coisa até no trato. (Wilson, COPEL)

Assim, a necessidade de planejar as ações de uma forma racional para os indígenas justificava até mesmo a sua desconsideração:

Houve um desinteresse de falar a língua do outro, de compreender... Isso, entre nós [da administração], talvez não tenha, até por exigência dos trabalhos em muito mais em compreender os índios porque eram nossos clientes (risos). A ideia é seguinte: porque assim, quando o administrador entra no âmbito racional, porque ele quer participar de todas as etapas do processo, porque ele tem que planejar, e o bom do planejador é que ele consegue se antecipar, prever o futuro. É, e isso exigia decisões que eram muito difíceis de tomar por vários motivos: porque elas se contrariavam muitas das vezes com os interesses indígenas. (Alberto, consultor do programa na área de Administração)

O discurso que permeia a fala de Alberto é o desejo de controlar, de enquadrar um modo de vida diferente nas regras dos "brancos". Como planejador, Alberto acredita na sua capacidade de fazer prognósticos, depositando uma enorme confiança nas técnicas racionais, minimizando o peso da complexidade social. Centrado em seus planos, esquece-se até que existe uma comunidade ao seu redor, uma comunidade que tem necessidades próprias.

Alberto trata o planejamento como uma técnica racional aplicada por especialistas, como os administradores. Aos índios resta aguardar passivamente os planos traçados por esses 
especialistas que não se deixam contaminar nem pelas emoções - "isso exigia decisões que eram muito difíceis de tomar" - nem pelas tradições, pois, se preciso for, os técnicos racionais irão contrariar até seus "clientes" para seu próprio bem. Trata-se, portanto, não de "povos autóctones e desenvolvimento", mas de "povos autóctones ou desenvolvimento", como conclui Perrot (2008, p. 219) sobre o conceito de desenvolvimento imposto às comunidades indígenas brasileiras.

Sem notar, Alberto agiu como aqueles que ele mesmo critica: desconsiderou o outro, impondo aos índios aquilo que ele acreditava ser o caminho correto. Ao planejar o modo como os indígenas deverão agir - separando as “categorias 'ajustadas' das 'desajustadas', as de 'valor' das 'inúteis' e estabelecer as condições nas quais podia ocorrer (se podia) as passagens das segundas para as primeiras" (BAUMAN, 1999, p. 118) - acaba por impor significados a eles, visando modificar o estado natural da comunidade pela ordem artificialmente planejada. Alberto se lembra que até que tentaram trabalhar de uma forma mais participativa com os índios, mas no final o que imperou foi a forma tradicional de intervenção:

Por maior esforço que tivemos para descaracterizar o tipo tradicional de intervenção, no fundo, no fundo, a gente... Eu vi, algumas pessoas perdiam a calma com os índios. Eles faziam umas coisas muito doidas... É isso que eu te falei, eles iam lá botava fogo em tudo. "Paaaaa, não vou dar porra nenhuma... corta, corta". Era uma forma de punição que tinha dos grandes. [...] Havia esse ímpeto de dizer: "porra, quem que manda aqui, caralho?". (Alberto, consultor do programa na área de Administração)

Talvez Alberto estivesse querendo dizer que no fundo isso seria impossível, uma vez que os "brancos" não conseguiam olhar de outra forma, devido à tradição elitista ${ }^{66}$ e autoritária em que foram socializados. Isso explica a forma como a resistência aos seus planos ${ }^{67}$ era

\footnotetext{
${ }^{66}$ Me refiro aqui à teoria elitista, formulada principalmente por Gaetano Moska e Vilfredo Pareto, que defendia, basicamente, "de que em qualquer sociedade, em qualquer grupo, em qualquer época ou lugar, havia sempre uma minoria, uma elite que, por seus dons, e sua competência e seus recursos, se destacava e detinha o poder, dirigindo a maioria", explica Grynszpan (1999, p. 11).

${ }^{67}$ Alguns dos consultores falaram sobre os incêndios provocados por alguns índios nas plantações de vassoura e no reflorestamento por não concordarem com as decisões tomadas para o programa.
} 
prontamente reprimida por meio das ameaças ao corte nos projetos ${ }^{68}$, sem se preocupar em entender o porquê da reação dos índios.

Na mentalidade daqueles que planejam esses programas, a absorção de novas técnicas produtivas e a mudança no seu modo de encarar a vida, os levaria a novos patamares na geração de renda e, portanto, ao desenvolvimento. Qualquer outro resultado que não tivesse relação com as questões econômicas é visto como perda de tempo e desperdício de recursos.

Para Hobart (2002, p. 1, tradução minha), "desenvolvimento é, efetivamente, um sinônimo para mudança social e econômica mais ou menos planejada". Neste contexto, os planejadores, aqueles que detêm o conhecimento científico, tratam o conhecimento local como ignorância, não como uma mera antítese ao conhecimento, mas um estado atribuído aos considerados subdesenvolvidos. Portanto, a ignorância é um julgamento moral. É assim que o conhecimento, especialmente o técnico, se tornou uma commodity que pode ser vendida ou transferida (HOBART, 2002), fazendo com que a ciência moderna se encontre com o poder, uma vez que a verdade e o único caminho a seguir são ditados pela ciência, se transformando, assim, em ideologia. Para Santos (2003), foi isso que aconteceu com a teoria do desenvolvimento econômico que, para se realizar como ideologia, convenceu os explorados de que eram apenas subdesenvolvidos que poderiam superar seu atraso apenas imitando os desenvolvidos.

A serviço do planejamento a economia perdeu seu status científico e se tornou simples ideologia, cujo fito é persuadir Estados e povos das vantagens daquilo que passou a ser chamado desenvolvimento: a venda da ideologia do crescimento dos Estados, a imposição de uma ideologia de sociedade de consumo às populações (SANTOS, 2003, p. 15).

\footnotetext{
${ }^{68}$ Juliana, uma das entrevistadas, me contou de um momento em que os índios passavam por um conflito interno e ela precisava entregar umas cestas básicas de um projeto de compensação alimentar pela reforma da usina recentemente concluída pela COPEL. A confusão era tanta que o cacique na época, responsável pela distribuição das cestas básicas na comunidade, se negav a a fazer a entrega em um das aldeias. Como isso estava atrasando a entrega das cestas, Juliana resolveu assumir o lugar do cacique e entregá-las, mas antes se certifica que os índios estejam cientes de que ela não iria tolerar nenhuma confusão: "Eu liguei pro Devanir, que é a liderança, e falei: 'Devanir, a gente vai entregar as cestas básicas nesse mês, tudo bem?' Aí eu falei: 'Devanir, a gente sabe que você está brigado. Eu não quero saber disso. Vai funcionar assim, eu vou aí, posso ir?' 'Pode'. 'Você me garante que não vai ter nenhum problema? Vocês não vão brigar?' 'Não'. 'Eu vou entregar aí e eu quero saber se não vai ter nenhuma confusão'. 'Não vai ter'. 'Então, assim, eu vou aí, se tiver alguma confusão todos os projetos vão ser cancelados" (Juliana, COPEL). Parece, portanto, que a ameaça ao corte dos projetos a fim de adequar os comportamentos dos índios ao desejado pelos "brancos" é uma constante.
} 
Grande parte dos envolvidos com o programa são cientistas, professores universitários que acreditam que as teorias científicas universais são capazes de "corrigir o problema dos índios”. Para eles, a solução para o desenvolvimento das comunidades indígenas é óbvia: aplicação estratégica do conhecimento científico. O problema é que, como criticam Adorno e Horkheimer (1999, p. 42) o uso da ciência como aparato do pensamento iluminista, o método científico utilizado por eles acaba por aprisionar o pensamento e "o desconhecido fica assim caracterizado como um velho conhecido, mesmo antes de se ter determinado seu valor".

Em Apucaraninha, prometeram que o programa iria "salvá-los", utilizando justificativas da seguinte ordem: "mudar a vida", "melhorar a vida", "viver melhor" e "viver de forma mais sustentável". Este discurso de mudança e melhoria foi constamente utilizado pelos entrevistados para esta tese ao se referirem tanto à indenização pela usina quanto ao Programa de Sustentabilidade Socioambiental de Apucaraninha, como pode ser visto nos relatos de Carlos, Wilson e Joana a seguir:

O que a gente pode fazer é dar subsídio àquilo que eles necessitam, mas não a gente ter a tomada de decisão por eles. Então, nós podemos apresentar: "olha, onde vocês podem ter potencial de produtividade máxima e onde vocês podem colocar suas roças de coivara, certo?". Agora se eles vão tomar essa decisão parte deles, não de mim. Eu, no momento que eu puder eu posso instrui-los com os melhores caminhos pra que eles obtenham o sucesso. Mas a decisão é deles. (Carlos, consultor do programa na área de Economia)

Mas para a comunidade seria importante para transformar a vida deles. Esses projetos iriam mudar a vida deles, né? Porque a ideia, eu acho, esse dinheiro vai acabar um dia, um dia ele acaba. E acabar com 12 milhões e não virar nada? (Wilson, COPEL)

Eu falei: "acho que eu tenho que ir atrás disso mesmo, contribuir nisso para que de fato isso mude a vida deles". Era na questão da mudança daquela primeira coisa que a gente ouviu, né: que agora vem indenização, virão os projetos, e esses projetos vão render frutos e eles vão ficar bem, nós não vamos ter crianças mendigando mais no sinaleiro, nos semáforos... (Joana, antropóloga, coordenadora do diagnóstico) 
Quase que inevitavelmente ligadas ao discurso de mudança encontramos as selexões lexicais "produtividade máxima", "melhor caminho para que eles obtenham sucesso" e "o dinheiro precisa ser gerido para render" (subentendido implícito), denotando o tipo de mudança que eles valorizam: materialista e utilitária, ligado aos interesses do mercado. Assim, mesmo que os kaingang não sejam predominantemente agricultores, a agricultura de precisão é apresentada a eles como uma alternativa superior, uma vez que "podem ter potencial de produtividade máxima", frente à roça de coivara, que não possui, para Carlos, nenhum adjetivo. Apesar de mostrar as opções, Carlos deixa claro, na sua fala, qual seria a melhor.

Não me dirijo aqui a toda ciência, mas a um tipo específico que não reconhece como conhecimento os saberes locais, por estarem excluídos dos cânones da hegemonia do modelo europeu e norte-americano. Uma ciência matematizada e assumidamente neutra que desconsidera que o olhar do cientista sempre é uma ficção, como nos lembra Fourez (1995). Uma ciência, portanto, que "não dialoga: deslegitima e desperdiça saberes e experiências" (HISSA, 2009, p. 74).

E, em se tratando do diálogo entre profissionais mais escolarizados e comunidades com baixa educação formal a situação ainda se complica, já que há, por um lado, um monopólio do saber técnico em detrimento do saber local e, por outro, a desvalorização do conhecimento da população menos escolarizada, que é vista como bruta e incapaz (VALLA, 1998).

Talvez seja muito difícil os profissionais/mediadores admitirem a cultura popular como uma teoria imediata, isto é, um conhecimento acumulado e sistematizado, a interpretar e explicar a realidade. A formação escolarizada da classe média, e mesmo daqueles profissionais que agem como mediadores entre os grupos populares e a sociedade (através de partidos políticos, ONGs, igrejas, sindicatos) freqüentemente os leva a negar conhecimento produzido, também, pelas classes subalternas. Assim, mesmo que alguns mediadores sejam mais atenciosos e mais respeitosos com as pessoas pobres da periferia, os muitos anos de uma educação de classe, preconceituosa, fazem com que o papel de tutor predomine nas suas relações com as classes populares (VALLA, 1998, p. 16). 
Assim, mesmo que entre os participantes do programa esteja presente o discurso da participação, ele serve mais para o processo do que tem valor de fato. Valla (1998) cita como exemplo o mediador que faz questão de abrir espaço para a participação da comunidade em uma reunião, a fim de mostrar seu compromisso com a democracia popular. No entanto, após a fala popular, retoma rapidamente a pauta da discussão, desconsiderando o que foi falado.

Muitos dos consultores simplesmente ignoraram o outro, não se abrindo para a troca de saberes nem entre eles e, muito menos, com os indígenas:

As reuniões eram absurdas, porque era cada um falando de uma coisa, uma linguagem, enfim. Fantástico tudo, mas tudo bastante arriscado. Havia os contatos. Mas eram contatos burocráticos, prestação de contas, não era de discussão. Acabou que ficando as grandes áreas mais próximas, junto com economia, com direito. É, não houve discussão, por exemplo, dos professores dos projetos juntos com várias áreas, então os projetos continuaram encastelados. (Alberto, consultor do programa na área de Administração)

Teve vezes que se teve a intenção de passar por cima mesmo desses saberes mais práticos, menos teóricos. Eu acho que essa é uma das coisas que pegou. Pessoas muito vaidosas, nesse sentido. Como que uma pessoa que não tem uma informação x ou y vai querer discutir comigo? [...] Eu não quero ouvir a outra que está há 20 anos convivendo, aquela experiência do cotidiano. Quer dizer, chegaram a um desequilíbrio ali que eles se recusavam a reconhecer o quanto o saber prático, para a perspectiva da universidade, ele é pouco valorado, ainda que seja dos indígenas. Conhecimento teórico é mais interessante que o conhecimento prático. Eles tentaram mais do que observaram. (Gisele, MPF)

"Não houve discussão" porque os participantes do programa se negavam a "ouvir a outra" parte, uma vez que os consultores estavam aprisionados em seus castelos de conhecimento. Essa postura os levou a situações como a descrita por Marcelo, um "branco" que trabalhou como mediador entre os consultores e os índios: 
O questionário era um desses exemplos da incapacidade de imaginar com quem iria dialogar. E houve um entrave. Eu participei muito da confecção de todas as entrevistas, de todos os questionários, de todas as perguntas, porque eu ia facilitar depois. Então na hora do administrativo tinha lá: "em qual subárea da Administração você gostaria de ser capacitado?" Você fica pensando: "como assim?" Tinha toda uma estrutura que forçavam os pesquisadores a ter um grau de... um questionário extremamente denso e técnico, que não seria condizente. Eu acho que a concepção inicial já teve problema. Não levou em conta o "com quem". E aí simplesmente trouxe do mundo corporativo e vamos aplicar isso para o melhor sucesso... Efetivamente ignorou quem é o seu interlocutor. (Marcelo, sociólogo, facilitador de campo durante o programa)

Além deste caso, ouvi de vários informantes que uma das equipes já chegou a Apucaraninha com o diagnóstico e projeto prontos, propondo que todo o dinheiro da indenização fosse gasto com a aquisição de terras na vizinhança. Na ideia destes consultores, ao adquirir mais terras, seria possível que cada família pudesse ter o seu quinhão para suprir sua sobrevivência e, ao mesmo tempo, formando novas aldeias eles poderiam exigir mais serviços do Estado, como saúde e educação, que iriam demandar mais mão-de-obra indígena. Nada mais sustentável, diziam eles.

O problema é que esta proposta não surgiu do diálogo entre os consultores e os índios e, desta forma, alguns empecilhos foram esquecidos. Primeiro, para os índios é inadmissível comprar as terras que eles consideram que sempre foram deles. Segundo, os índios não são camponeses que vivem em propriedades privadas. Ao invés de um diálogo, é estabelecido um monólogo, no qual os indígenas se tornam cooptados - permanecendo "domesticados", como afirma Almeida (2010) - apenas legitimando as decisões que foram antecipadamente tomadas. É assim que, para Almeida (2010, p. 181, grifo do autor), “a representação indígena que está sendo demandada [...], ao invés de garantir um protagonismo indígena, é pouco mais do que uma representação "para inglês ver"'.

Fica claro, portanto, que no Programa de Sustentabilidade em Apucaraninha, quem dá as cartas, no final, é a COPEL. Primeiro, como já vimos aqui, porque o programa foi desenhado conforme a visão da companhia. Segundo, porque a sua presença é tão forte que domina no processo de gestão do programa. Além do reconhecido saber técnico em gestão que já foi 
mencionado, seu poder econômico é bastante evidente. Para Wilson, um dos participantes do programa, o Comitê Gestor ${ }^{69}$, criado como instância colegiada decisória, já é dominado pela empresa e serve mais como instrumento de controle dos índios.

\begin{abstract}
Eles não colocaram a mão no dinheiro. Então eles não têm poder de decisão sobre o que fazer. O Comitê Gestor acaba servindo, na realidade, como um meio de controle. Você coloca três pessoas da COPEL lá que são freios dos anseios dos projetos que eles podem, por ventura, inventar. (Wilson, COPEL)
\end{abstract}

O que Wilson quis dizer é que a COPEL reprime ("são freios") os desejos dos indígenas. Os funcionários da COPEL que participam do Comitê Gestor atuam como vigilantes dos objetivos da companhia, uma vez que desta forma pensam poder garantir a forma "correta" em que os índios irão gastar os recursos da indenização. Essa forma "correta" não leva em conta os fatores socioculturais da comunidade, já que os representantes da COPEL não foram preparados para compreender as racionalidades e formas de vida dos indígenas, como defende Wilson ao dizer que todos, inclusive ele, foram totalmente despreparados para aquela situação específica.

No entanto, a forma como este relacionamento entre indígenas e funcionários da COPEL se firmou durante o programa implicou o estabelecimento de vínculos de proteção. Nas minhas conversas com os índios, era comum eles se referirem à COPEL como parceira que luta por eles - "COPEL também é uma parceira nossa também que batalha muito" (Miguel, kaingang da TI Apucaraninha), que só queria o bem dos índios - "eles estão querendo fazer bem pra nós" (Joaquim, kaingang da TI Apucaraninha). Foi com a COPEL que aprenderam como ter uma vida melhor, fazem questão de dizer alguns índios.

Muitas vezes os índios ao falarem das ações do programa se referiam aos recursos que os financiavam como sendo da COPEL e não do fundo que pertencia à comunidade. Para os Kaingang, ainda é difícil separar o que é da empresa e o que é deles, fazendo com que muitas ações em que a COPEL esteja envolvida sejam vistas como uma ajuda abnegada. Como alerta Baines (2014, p. 3):

\footnotetext{
${ }^{69}$ O Comitê Gestor é formado por três representantes da COPEL e três da comunidade indígena, tendo o MPF e a FUNAI assentos garantidos (CIMBALUK, 2014).
} 
Estes projetos vêm sendo frequentemente apresentados como se fossem benefícios concedidos pelas empresas, promotoras de alternativas de desenvolvimento para os povos indígenas na forma de projetos assistencialistas e mitigadores dos chamados "impactos" dos projetos de desenvolvimento. Nesse sentido, argumentamos que representam novas formas de dominação.

O exercício da proteção leva a submissão daqueles que se sentem protegidos, avisa Lima (2012, p. 785):

Se o tutor tem como encargo instruir, ele age simultaneamente de modo a se eternizar na posição de fonte última de autoridade, da transmissão dos conhecimentos e dos modos corretos de vivenciar o pertencimento a uma comunidade mais abrangente.

É por isso que os indígenas já aceitaram o discurso dos "brancos" com relação a eles. Assim, repetem o tempo todo que os índios não sabem administrar, que não sabem guardar para o futuro e que, portanto, não podem ficar responsáveis pelo dinheiro da indenização, como na fala de João (Kaingang da TI Apucaraninha): “eu falo para os meus companheiros: é bom que tem o Ministério Público junto com nós ali. Se não tivesse o Ministério Público nós tínhamos torrado tudo o dinheiro que está lá guardado".

A dependência está tão presente que um índio quando indagado por mim sobre o que pode acontecer quando a COPEL se retirar da comunidade, encerrando o prazo do programa, ele responde desolado: “é, tudo vai acabar" (Francisco, kaingang da TI Apucaraninha). Ao controlar o programa, a COPEL controla os próprios índios, como sustenta Alberto:

Nunca entendi porque a COPEL queria tanto controlar esse programa. Nunca, assim, ficou evidente, sei lá. Talvez eles não quisessem que a gente não torrasse tudo, porque eles sabiam que quando os índios torrassem tudo eles iam bater na porta da COPEL: querem que a gente feche tudo aqui? Porque eles fechavam, eles sequestravam. Eu acho que a COPEL teve talvez um inimigo assim do lado. Então, é possível controlar. Era um inimigo 
dentro de casa, então ela precisa investir muito para cuidar disso. (Alberto, consultor do programa na área de Administração)

$\mathrm{Na}$ fala de Alberto, os índios são vistos como inimigos da COPEL. Inimigos íntimos que a companhia só tolera porque precisa deles ${ }^{70}$, já que o funcionamento da usina depende da colaboração dos índios. Antes do acordo, por exemplo, os índios fecharam a usina, mantiveram em cativeiro os empregados da companhia e ameaçaram por fogo na casa de máquinas caso a companhia não aceitasse negociar a indenização que eles pediam.

Assim, o medo da companhia é que os índios gastem todo o recurso e comecem a pressão para receber outros valores. Mesmo juridicamente fundamentada, já que o acordo assinado em 2006 já previa que novos valores não poderiam ser pleiteados pelos índios ${ }^{71}$, qualquer insatisfação dos indígenas poderia gerar prejuízos à empresa devido à interrupção dos geradores da usina. Esta preocupação já foi apontada por Cimbaluk (2013, p. 118) na sua pesquisa na Terra Indígena Apucaraninha:

Dentro da empresa [...] existe uma visão de controle de gastos desenfreados pelos índios, o que poderia gerar novos pedidos e manifestações pela comunidade. Desta forma, a empresa teria se mantido na gestão de tais recursos. [...] Cabe notar que me foi relatado que antigo empregado

\footnotetext{
${ }^{70}$ Se não fosse obrigada a lidar com os índios, a COPEL não teria qualquer relacionamento com eles, como afirma uma das funcionárias da empresa que trabalha no programa: "é totalmente fora do foco. Assim, como eles adoram dizer, que não é um negócio da empresa. Só que você tem determinantes legais que me obrigam a cumprir certas normativas, principalmente na área ambiental. Então, por isso tem uma divisão específica sobre isso. [...] Mas, é claro né, a gente é os que emperram o trabalho. Os chatos. Os abraçadores de árvore (Juliana, COPEL)". Juliana lembra que o trabalho executado por eles é motivo de chacota entre os outros empregados da empresa. Normalmente eles são vistos, de forma pejorativa, como ambientalistas hippies ("os abraçadores de árvore"), aqueles "chatos" para os quais tudo não pode e, portanto, são os que "emperram o trabalho" da empresa, uma vez que as questões ligadas à responsabilidade social não tem qualquer relação com o "negócio da empresa". Assim, ao rotulá-los desta forma, deixam claro que seu trabalho não é levado a sério, sendo considerado menor do que de outras áreas da empresa, como as ligadas às engenharias, mais alinhadas ao core da organização. O desprezo aos "ambientalistas hippies" pelos outros empregados da empresa me leva a questionar até que ponto as práticas de responsabilidade social da empresa são efetivas. Da mesma forma que Saraiva e Irigaray (2009, p. 346) consideraram pouco efetivas as políticas de estímulo à diversidade nas filiais brasileiras de uma companhia multinacional "devido ao preconceito arraigado dos empregados, a certa permissividade gerencial e à ausência de senso coletivo de diversidade", é possível levanter a hipótese de que as práticas de responsabilidade social da COPEL não são levadas à sério, sendo mais para atender as pressões legais. Mas, como não tenho respostas para essa questão por não ter trabalhado mais a fundo o fenômeno, já que ele foge do escopo do meu estudo, prefiro apontar a sua ocorrência sem, no entanto, chegar a uma conclusão sobre a efetividade ou não das práticas de responsabilidade da empresa.

${ }^{71}$ Raul Munhoz Neto, então diretor de geração e transmissão de energia da COPEL, disse o seguinte no dia da assinatura do acordo com os Kaingang: "esse acordo zera e liquida todos os impactos provocados pela usina, indenizando desde o uso da mão-de-obra indígena nas obras de construção da usina até a vegetação e as terras que foram alagadas com a formação do reservatório" (COPEL, 2006, s/p). Fala completamente apoiada pelo Termo de Ajustamento de Conduta (MPF, 2006).
} 
responsável pela coordenação do Comitê, que iniciara as negociações com os índios, teria certo orgulho em ter atrasado seu uso por vários anos.

Ao "amansar" os indígenas, a COPEL parece ter alcançado seus objetivos, pois com o programa a companhia pode operar a usina dentro da terra indígena com tranquilidade, não se preocupando mais com a intervenção dos kaingang. Como frisa uma das entrevistadas:

A COPEL foi a única que atingiu os objetivos dela ali de fato. Em que sentido? A COPEL tinha uma presença boa lá na comunidade que resultou em uma relação muito melhor com as comunidades. Hoje a COPEL entra, faz o trabalho dela lá. Tem todo um diálogo com as comunidades, pacífico. Muito porque também ela se envolveu no processo, na gestão dele ali. (Gisele, MPF)

Mas, com o controle majoritário da COPEL, a relação tende a ser tutelar, bem alinhada a ideia de "indigenismo empresarial", como definido por Baines (2014). Se por muitos anos os indígenas eram dependentes da FUNAI, agora são dependentes das empresas que praticam um “indigenismo empresarial”, uma forma privatizada do indigenismo que camufla seus interesses capitalistas atrás dos programas compensatórios.

Utilizando a tutela que, na visão deles, é necessária, visto que o índio não consegue sobreviver sozinho, determinam o abandono dos seus costumes para adotar a dos "brancos", considerada superior frente ao modo atrasado em que vivem as comunidades indígenas. É desta forma que a tutela está impregnada da imagem estereotipada dos índios. 


\section{MUNDO À PARTE: O OLHAR HOMOGENEIZADOR DOS "BRANCOS" SOBRE OS ÍNDIOS}

Há uma imagem estereotipada dos indígenas que afetam as interações entre "brancos" e índios, já que as atitudes das pessoas perante estes últimos se tornam discriminatórias. Se o índio é visto como um ser indolente, dificilmente iremos olhá-los de uma forma "produtiva", conforme os imperativos da sociedade "civilizada". Da mesma forma, se a imagem disseminada dos índios é de um povo atrasado e irracional, como pensar em lhes "dar" autonomia?

A constituição de qualquer programa que envolva a interação entre "brancos" e índios será sempre problemática, quando os estereótipos estão presentes de forma marcante. Com base nestes estereótipos, já se espera encontrar características pré-determinadas, o que irá determinar a forma como qualquer programa de desenvolvimento será planejado e executado. É o que veremos neste capítulo, quando discuto a força dos estereótipos entre os consultores e outros participantes "brancos” do Programa de Sustentabilidade de Apucaraninha.

\subsection{Imagem do índio: estereótipos}

Um dos primeiros aspectos que chama a atenção na fala dos não-indígenas envolvidos com o Programa de Desenvolvimento Socioambiental e Cultural da Terra Indígena de Apucaraninha é a forma como todos enxergam o índio como "diferente". À primeira vista, a constatação da diferença na fala da maior parte dos entrevistados parece estar alinhada ao conceito de alteridade, ou seja, "como a característica própria do outro de ser realmente outro, fora da razão do mesmo, da totalidade (Sistema), ou do 'outro eu"' (PELIZZOLI, 2002, p. 230), favorecendo o diálogo e o respeito.

Esta diferença deveria ser levada em consideração durante o diagnóstico e a proposição de projetos, posto que as ações do programa, para que alcancem os resultados, têm que estar alinhadas às formas que os indígenas interpretam o mundo. Sob este prisma, o caráter multicultural da sociedade é posta em cena, situando as diferenças e, assim, conferindo poder aos grupos historicamente excluídos. 
Entretanto, esta seria uma leitura inocente, uma vez que, demarcando a diferença entre os "brancos" e os indígenas, deparei-me constantemente com uma imagem homogeneizada, como se estivessem falando de um índio imaginário e de "uma realidade social que é ao mesmo tempo um 'outro' e ainda assim inteiramente apreensível e visível”, conforme já dito por Bhabha (1998, p. 111) sobre o olhar do colonizador. A imagem que criamos de um determinado grupo que conhecemos de forma superficial é normalmente homogênea, dado que "os outros nos parecem mais ou menos todos iguais" (CAVAZZA, 2008, p. 106).

Esta imagem está baseada em estereótipos, falsas representações da realidade, fantasias que têm como objetivo hierarquizar e marginalizar (BHABHA, 1998). Criamos estereótipos porque necessitamos justificar e dar legitimidade a alguma ideia ou comportamento pessoal, do nosso grupo ou do sistema (CAVAZZA, 2008). De forma mais específica, a função justificadora dos estereótipos opera em três níveis: a) autojustificação: quando os indivíduos a utilizam para justificar a própria posição social ou o comportamento pessoal; b) justificação do grupo: quando os estereótipos são utilizados para consolidar a imagem positiva do seu grupo e distingui-lo dos outros grupos; c) justificação do sistema: utilizada para legitimar o status quo e as diferenças sociais.

Como afirma Hooks (1992) sobre a construção do estereótipo da população negra nos Estados Unidos, imagens das minorias, inclusive dos nativos americanos, foram criadas para afirmar e reafirmar a superioridade racial do grupo dominante na sociedade, os brancos, estabelecendo a ideia de supremacia branca. Apesar das diferenças entre os Estados Unidos e o Brasil no que tange à questão racial, em ambos "o sistema foi baseado na ideologia da supremacia branca", constata Telles (2004, p. 4, tradução minha). Ancorada na ideia da superioridade racial da população branca, "mais 'civilizada', mais inteligente e destinada a dominar", subjugaram as populações não-brancas - negros e indígenas - também por meio da imposição de uma imagem, geralmente negativa, a essas populações (HOOKS, 1992, p. 184, tradução minha).

Devido a isso, ao pensarmos em um índio já o criamos com base nos estereótipos, naquelas características imaginárias que os diferenciam dos não-índios, tomando todos os indígenas a partir de uma só representação. É assim que criamos nas nossas cabeças a imagem do índio $\mathrm{nu}$, com os corpos pintados, enfeitados com penas e portando o arco-e-flecha ou um tacape. Isso quando não são descritas as características comportamentais estereotipadas dos indígenas, como a indolência, o paganismo, a preguiça, o primitivismo e o exotismo. O índio, 
então, se torna encapsulado e fixado, sendo negado o reconhecimento da sua diferença como indivíduo, já que a imagem que chega a nós é de uma "massa desprezível", nos termos de Said (2008). A diferença, neste caso, surge não como signo de alteridade, mas como signo de distinção.

Por muito tempo, os indígenas foram mantidos à distância do restante da sociedade brasileira. Colocados em aldeias, separados da sociedade "civilizada", tornaram-se quase uma lenda. Poucas páginas nos livros didáticos sobre a história do Brasil são relacionadas a eles. E ainda nelas abundam preconceitos e estereótipos contra as populações indígenas (GRUPIONI, 1996). Eu me lembro de que, ainda no ensino fundamental, a justificativa dada para a escravidão dos negros era que os índios eram indolentes e, portanto, não serviram para o trabalho.

Qual não foi minha surpresa ao me deparar com esta mesma imagem entre pessoas que receberam informações antropológicas e históricas sobre os indígenas para participar do programa de sustentabilidade com os kaingang de Apucaraninha? Uma dessas falas é a do consultor Sílvio:

Olha... Então, é uma cultura diferente. Eles estão muito acostumados a vender a mão de obra deles. Vai lá, trabalha dois, três dias, depois volta, depois vai trabalhar dois, três dias. Eu entrevistei muito os indígenas lá e a gente percebeu que, assim, eles têm a característica diferente da nossa. Nós precisamos trabalhar e ficar acumulando. Precisamos, né? Eles, não. Então, não tem aquela de ser apegado ao dinheiro. $\mathrm{O}$ apego deles ao dinheiro é infinitamente menor que o nosso. Eles querem receber o dinheiro da indenização porque eles querem comprar as coisas, eles querem ter as coisas. Veja, eles já foram contaminados pela nossa cultura. Então, tem isso. Fala que não? Mas aquela cultura de juntar, de trabalhar muito... Eles, não. Eles gostam de consumir porque isso é fácil. O consumo eles gostam, qualquer um gosta, isso é muito fácil de assimilar. Essa cultura de consumo é muito fácil de assimilar. A cultura de trabalho, que é já mais difícil de você determinar; uma cultura de trabalho, mais extensivo. Vou te dar um exemplo: eu entrevistei um indígena e perguntei pra ele assim: "você trabalha?" Ele falou: "trabalho". Falei assim: "todo dia? Quantos dias na semana?" Ele respondeu: "dois dias". Aí tem um outro que eu perguntei 
assim: "você trabalha?" "trabalho". "E todo dia?" Ele falou: "não, trabalho, outro cansa". Ele trabalha num, noutro cansa. (Sílvio, consultor do programa na área de Economia)

Sílvio fala a partir da sua posição de membro de um segmento social, a classe média ${ }^{72}$ brasileira ("nós), para o qual o trabalho significa, em um primeiro momento, a sua humanização. Inspirados pela filosofia hegeliana de que o trabalho é um produto da cultura humana - por isso que Sílvio fala em "cultura do trabalho" - e, portanto, uma manifestação da evolução de um povo (SOUZA, 2012), uma sociedade que não possui os mesmos valores é considerada atrasada por causa da sua indolência.

Para esta classe média pela qual fala Sílvio, o trabalho também é o meio para chegar à riqueza, dado que a ela é prometida a ascensão social como recompensa do trabalho árduo. Assim, Sílvio afirma: "nós precisamos trabalhar e ficar acumulando". O trabalho está, portanto, diretamente ligado ao acúmulo de bens e dinheiro e, portanto, é central na vida dentro de uma economia capitalista. Essa necessidade não está ligada, nas palavras de Sílvio, a sobrevivência e sim a uma necessidade social, tanto pessoal quanto coletiva, uma vez que o trabalho duro é um mecanismo de progresso individual e social. Afinal, já dizia Adam Smith (1996) que, em nome do interesse pessoal, as ações econômicas individuais permitem a humanidade alcançar o máximo de bem-estar.

Para Sílvio, o trabalho humano é uma mercadoria ("vender a mão de obra"). Quando vendemos algo, perdemos o direito sobre ele. É assim que para Sílvio o trabalho não pertence aos índios, mas àqueles que pagam por ele, sendo que os primeiros perdem o direito de decidir como ele será aplicado, dado que "não cabe à mercadoria decidir onde será oferecida à venda, para que finalidade será usada, a que preço ser-lhe-á permitido trocar de mãos, e de maneira ela deve ser consumida ou destruída", fala (POLANYI, 2000, p. 213).

Baseado nestas ideias, Sílvio demonstra desprezo pelo que ele considera uma falta de apego dos kaingang ao trabalho duro, já que não o fazem de modo "extensivo". Ou seja, Sílvio

\footnotetext{
${ }^{72} \mathrm{O}$ conceito de classe media é controverso. No entanto, não tenho como objetivo travar uma discussão sobre o assunto. Então, aqui, de forma bastante simplista, proponho que a classe média seja vista como uma categoria residual que não corresponde ao topo da pirâmide, onde estão localizados os detentores dos meios de produção e rentistas, e nem a classe mais baixa que vive em completa pobreza. Para maiores informações sobre o conceito de classe média ver Adamovski (2013).
} 
entende o trabalho valoroso aquele que é executado oito horas por dia, no mínimo 40 horas por semana, e, além disso, remunerado como nos foi imposto no começo do século XX. $\mathrm{O}$ trabalho realizado de forma esporádica ou necessário à sobrevivência não é considerado, visto que, segundo Gorz (2007, p. 21), “a característica mais importante [do] trabalho - aquele que 'temos', 'procuramos', 'oferecemos' - é ser uma atividade pública, solicitada, definida e reconhecida útil por outros [...] e, a este título, remunerada".

É assim que os índios são vistos como indolentes, frente à massa de valorosos trabalhadores não-índios que trabalharam (e trabalham) de sol a sol para o progresso desta terra. Para Memmi (1977, p. 77):

Nada poderia legitimar melhor o privilégio do colonizador que seu trabalho; nada poderia significar melhor o desvalimento do colonizado que sua ociosidade. O retrato mítico do colonizado conterá então uma inacreditável preguiça. O do colonizador o gosto virtuoso da ação.

O que deixa Sílvio ainda mais indignado é que apesar de não gostarem de trabalhar, os índios gostam de consumir, uma vez que já foram "contaminados pela nossa cultura”. Contaminar é o mesmo que corromper, ou seja, tirar os índios de uma situação ética considerada ideal para uma de moral negativa. Neste ponto, Sílvio deixa transparecer a imagem de bom selvagem que ele tinha dos índios antes do seu contato com eles, uma vez que, para ele, índio bom é índio puro, não contaminado pela cultura da sociedade envolvente.

Gordon (2006) afirma que o preconceito dos "brancos" com o consumo dos índios é porque ele destrói a figura do bom selvagem que alimentamos durante anos. Encarar este índio consumista, da mesma forma que a maior parte dos humanos, é bastante difícil, uma vez que as diferenças entre eles e os "brancos" são derrubadas, acabando com o mito. Assim, a dificuldade maior está na aceitação de que os índios se relacionam com a produção dos "brancos", da mesma forma de que com a nossa história, de um ponto de vista diferente.

Há uma questão de fundo em todo o caso, que reside em nossa incapacidade de enxergar as relações dos índios com os objetos oriundos da sociedade industrial capitalista como um fenômeno autêntico. Apesar de sabermos que nosso mundo é movido pela produção em massa de objetos, pela produção 
do desejo voltado a eles e por seu consume igualmente massivo, quando se trata dos índios é como se houvesse um imperativo de separação. Os índios não podem querer tais coisas que lhes são estranhas e, se as querem, algo estranho lhes acomete. Paira sobre esse conjunto de ideias diversos espectros, entre eles o do bom selvagem, já transmudado e revestido de camadas de ectoplasma culturalista. Eles dizem muito mais sobre a nossa relação com os índios do que sobre a relação dos índios conosco. É como se olhássemos os índios sempre através de um mesmo espelho, que só pode nos devolver nossa própria imagem distorcida. Em qualquer caso, é a alteridade que se suprime na reflexão: ou os selvagens são aquilo que nós não somos, mas projetamos em um nosso passado edênico ou em um nosso futuro redentor ou eles não passam de um outro nós, com os mesmos defeitos e pecados (GORDON, 2006, p. 37).

Para Limberti (2012), a gênese desta imagem congelada pode ser encontrada nos primeiros contatos, há mais de 500 anos, quando os europeus construíram uma representação do índio como o exótico, livre dos pudores dos que vinham do velho mundo, vivendo em uma comunhão quase divina com a natureza. Da carta de Pero Vaz de Caminha ao Rei de Portugal quando da chegada dos navegadores portugueses em terras brasileiras, aos relatos de viajantes

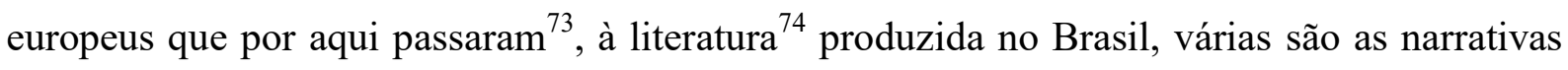
que colaboraram com a divulgação do estereótipo dos índios. Em todas essas obras, o "branco" fala sobre os índios conforme sua interpretação, "somadas à fantasia meticulosa das observações do real" (SANTOS, 2009, p. 15). Passado tantos anos, esta imagem foi reproduzida de diferentes formas que se manteve viva na mente das pessoas.

Entretanto, essa imagem foi confrontada pelo índio de carne e osso que ele encontrou em Apucaraninha. Um índio que foi contaminado pela cultura dos "brancos", porque gosta de consumir. O consumo, então, está aqui relacionado ao consumismo, um fenômeno moderno que está, "por sua própria natureza, mais preocupado em saciar vontades do que em satisfazer necessidades", como defende Campbell (2006, p. 49). Sendo assim, é um consumo individualista, originado nas emoções e sentimentos e não na razão utilitária.

\footnotetext{
${ }^{73}$ Um exemplo é o caso de Hans Staden, um alemão que fora capturado no litoral brasileiro por índios Tupinambás no século XVI, que assim que retornou à Europa lançou suas memórias no livro Viagem ao Brasil (STADEN, 1930).

${ }^{74}$ No século XIX, inspirados no romantismo europeu, escritores brasileiros como José de Alencar e o poeta Gonçalves Dias insistem na idealização dos indígenas, agora um bom selvagem aliado dos colonizadores.
} 
A ética do trabalho, forjada na "autodisciplina e autonegação, tendo em vista as gerações futuras", foi substituída pela do consumo, tendo o trabalho não mais "um fim em si mesmo", mas "um meio para aquisição de mercadorias", frisa Bendassolli (2007, p. 15). É neste ponto que Sílvio condena o consumo, ou melhor, o consumismo: por ele não ser considerado racional. Para ele, é inconcebível que o dinheiro da indenização seja gasto com consumo ("eles querem receber o dinheiro da indenização porque eles querem comprar as coisas") e não para a geração de trabalho que será revertido em acúmulo. Para Gaulejac (2007, p. 77), “a preocupação com a utilidade é facilmente concebível em um universo em que as preocupações com a eficiência e a rentabilidade são constantes".

Talvez Sílvio não coloque a culpa nos índios, mas nos "brancos" que não foram capazes de impor ("a cultura de trabalho, que é já mais difícil de você determinar") o valor do trabalho, da mesma forma que fez com a do consumo. Fica claro nesta passagem que Sílvio vê as pessoas como sujeitos passivos que aceitam e reproduzem as normas e valores da ideologia dominante. Desta forma, o índio estaria à espera de uma ação efetiva e bem orquestrada dos "brancos" para mudar seu modo de vida e se adequar ao capitalismo. Trata-se da naturalização da dominação do colonizador sobre o colonizado.

O discurso do colonizador se baseia na ideia de diferença e não de diversidade, uma vez que "a diferença cultural é um processo de significação através do qual afirmações $d a$ cultura ou sobre a cultura diferenciam, discriminam e autorizam a produção de campos de força, referência, aplicabilidade e capacidade", avisa Bhabha (1998, p. 63, grifos do autor). Segundo Bhabha (1998, p. 111), “o objetivo do discurso colonial é apresentar o colonizado como uma população de tipos degenerados com base na origem racial de modo a justificar a conquista e estabelecer sistemas de administração e instrução". Ao criar esta hierarquia entre as diferentes sociedades, sendo o colonizado visto como atrasado, impõe a ideia de superioridade do colonizador, aquele ser abnegado que cumpre seu trabalho, ensinando os colonizados a se civilizar.

É o que pensa Alberto, um dos consultores do Programa de Sustentabilidade em Apucaraninha, que faz uma oposição direta entre os "brancos" - portadores do progresso - e os índios - atrasados e dependentes da tutela dos "brancos", conforme os personagens encontrados em sua fala. 
Os índios vivem no mundo à parte, juntos e separados. Então, eles têm uma luta histórica com os brancos por território. $\mathrm{E}$ a gente consegue entender que isso tudo está cristalizado, por exemplo, em um grande ódio, numa grande revolta contra qualquer tentativa branca de tentar organizá-los, intervir. Então, por exemplo, eu ouvi uma palavra assim: "por favor - o pessoal falava - não fale projeto pra índio que eles odeiam essa palavra". Então, falar projeto para eles é uma palavra carregada de simbolismo, de poder branco, ou seja, "eu tenho um projeto pra você" é antiético, traz consigo uma violência que ignora toda a condição deles. Então, tinha esses cuidados. (Alberto, consultor do programa na área de Administração)

Quando se refere aos índios como vivendo em um "mundo à parte", faz referência a um mundo separado do mundo que ele conhece, o dos "brancos". Um mundo que está fora do tempo e do espaço físico do mundo que progrediu, que se modificou. Há uma contraposição direta aqui responsável pelos interdiscursos: o mundo primitivo dos índios versus o mundo civilizado dos não-índios. Seria este um novo mundo a ser civilizado?

Outras falas dos participantes do programa espelham justamente esta necessidade, uma vez que a Terra Indígena é vista como um lugar sem lei e, portanto, não civilizado, "um campo aberto para as intervenções civilizadoras" (MOREAU, 2003, p. 20). Cito aqui, como exemplo, a fala de Juliana que foi designada para trabalhar no projeto e que, assim, teve que se instalar na cidade de Tamarana que abriga a Terra Indígena:

Bom, no começo aquilo era horroroso pra mim. Eu acho que foi uma das... que eu lembro dali, tenho muitas péssimas lembranças. Então todo fim de semana, sexta feira eu ia pra casa, ia pra Maringá e voltava no domingo à noite. Então eu acho que eu fiquei ali, em um ano e meio que eu fiquei ali, eu acho que um fim de semana, um ou dois no máximo porque a minha mãe estava ali com a minha irmã. Mas eu não ficava ali de forma nenhuma, porque pra mim era sufocante, era, assim, opressor. É terrível, é terrível. $\mathrm{Na}$ verdade eu já não gosto do clima da cidade. Clima de faroeste, terra sem lei. Essa é a impressão que eu tenho de lá. (Juliana, COPEL)

Como descreve Juliana, ela nunca se sentiu em casa em Tamarana ("todo fim de semana, sexta feira eu ia pra casa, ia pra Maringá e voltava no domingo à noite"). Ela não fala 
especificamente dos Kaingang, uma vez que a cidadezinha de 12.000 habitantes (IBGE, 2014) é formada por cerca de $14 \%$ de indígenas. Entretanto, seu círculo de relacionamento na cidade, como ela mesma afirma em outro trecho da sua entrevista, sempre foi composta majoritariamente por indígenas, já que ela tinha ido para lá para trabalhar no programa. Então, é emblemático quando ela diz se sentir sufocada ("sufocante" e "opressor") na cidade que ela descreve como um lugar sem lei (“clima de faroeste, terra sem lei”), ou seja, uma terra não civilizada.

O discurso de Juliana é marcado pelo dualismo presente nos discursos hegemônicos em que há uma oposição entre o "índio e o "branco", “o primitivo e o civilizado", “o tradicional e o moderno", "economia de subsistência e economia de mercado" e "o regime jurídico brasileiro e o regime jurídico kaingang". E como todo dualismo, sustentado na ideia de hierarquização, em que uns se apresentam superiores e outros inferiores, que justifica as relações de poder (CABAÇO, 2009). Este desequilíbrio está em função da imagem idealizada dos índios historicamente construída.

As culturas indígenas, por serem consideradas "atrasadas", sempre foram vistas com desprezo pelos não-índios (FREIRE, 2002). Os índios devem aprender português, mas os "brancos" dificilmente aprendem as línguas dos indígenas. As religiões indígenas até hoje são consideradas como um conjunto de supertições, quando não são endemonizadas por padres, pastores e fiéis cristãos ${ }^{75}$. Os saberes indígenas não são considerados racionais e, portanto, não são válidos como fontes de conhecimento ${ }^{76}$, dado que são constantemente considerados misticismo.

\footnotetext{
${ }^{75}$ Matéria veiculada no Jornal da Band em 2008 aborda a intolerância religiosa promovida por religiões cristãs entre os povos Guarani no Mato Grosso Sul. O jornalista Fabio Pannunzio denuncia que as casas de reza tradicional estão sendo incendiadas pelos pastores e que até mesmo o uso de urucum na pintura corporal é proibida, já que para os líderes evangélicos o urucum é a "bosta do diabo". Vídeo disponível em: https://www.youtube.com/watch?t=123\&v=h1ZDaMaBDHA. Acesso em: 28 Jul. 2015.

${ }^{76}$ Freire (2002) conta que o preconceito contra os saberes indígenas nos levou a diversos erros. "Um desses erros foi percebido no início de 1985, durante o sério acidente sofrido pela usina nuclear de Angra dos Reis, construída num lugar que os índios Tupinambá haviam denominado de Itaorna e que até hoje é conhecido como este nome. Nesta área, na década de 1970, a ditadura militar começou a construir a Central Nuclear Almirante Álvaro Alberto. Os engenheiros responsáveis pela sua construção não sabiam que o nome dado pelos índios podia conter informações sobre a estrutura do solo, minado por águas pluviais, que provocavam deslizamentos de terra das encostas da Serra do Mar. Só descobriram que Itaorna quer dizer "pedra podre", em fevereiro de 1985, quando fortes chuvas destruíram o Laboratório de Radioecologia que mede a contaminação do ar na região. O prejuízo calculado na época em 8 bilhões de cruzeiros, talvez pudesse ser evitado se não fossemos tão burros e preconceituosos".
} 
Como lembra Terena (2000, p. 164), "nós, os sobreviventes do grande holocausto indígena, nunca podemos compreender os vários aspectos de relacionamento com o homem branco. Tivemos que nos educar para esse novo contato, mas a recíproca nunca foi verdadeira". O índio sempre foi visto como primitivo e improdutivo, um entrave ao progresso do restante da humanidade. Assim, o que as sociedades indígenas têm para ensinar aos não-indígenas, civilizados e portadores do conhecimento? Em uma das passagens de O Povo Brasileiro, Darcy Ribeiro (1995, p. 45) descreve o olhar do português sobre o índio:

Aos olhos dos recém-chegados, aquela indiada louçã, de encher os olhos só pelo prazer de vê-los, aos homens e às mulheres, com seus corpos em flor, tinha um defeito capital: eram vadios, vivendo uma vida inútil e sem prestança. Que é que produziam? Nada. Que é que amealhavam? Nada. Viviam suas fúteis vidas fartas, como se neste mundo só lhes coubesse viver. [...] Para os recém-chegados, muito ao contrário, a vida era uma tarefa, uma sofrida obrigação, que a todos condenava ao trabalho e tudo subordinava ao lucro.

É claro que visões de mundo tão diferentes resultariam em incompreensões. Os conhecimentos dos povos indígenas não serviam de nada para os "brancos". Dos índios os "brancos" só desejavam seus corpos para lhes servir. Como escreve Ribeiro (1995, p. 48), "nada que os índios tinham ou faziam foi visto com qualquer apreço, senão eles próprios, como objeto diverso de gozo e como fazedores do que não entendiam, produtores do que não consumiam".

Como não poderia deixar de ser, tal situação é potencialmente geradora de conflitos, manifestos, por exemplo, pelas seleções lexicais "luta histórica" e "grande revolta contra qualquer tentativa branca de tentar organizá-los”. Para Alberto, o rancor dos indígenas é compreensível ("a gente consegue entender”), mas não justifica hoje em dia a recusa da ajuda dos "brancos". Para eles, os casos de trabalho escravo e determinação de um modo de vida conforme o padrão dos "brancos" ficou no passado, é história. Alberto reconhece o passado destes índios e sabe, perfeitamente, como ele os conformou ("a gente consegue entender que isso tudo está cristalizado"), mas, ao mesmo tempo, ele o nega, o colocando no lugar em que deveria ficar, no passado, já que ele usa estratégias que modificam as ações intervencionistas de forma simbólica, mas não na prática, mantendo tudo como sempre foi. 
Hoje, a resistência força os "brancos", que, como defendem, só querem ajudar ensinando suas práticas para o desenvolvimento dos povos indígenas, a camuflar, ou seja, esconder sua atuação não pronunciando palavras que têm um peso histórico na luta entre as duas civilizações - "tinha esses cuidados". Ao camuflar a palavra "projeto", já decodificada pelos índios como carregada de um significado negativo ("poder branco"), tenta-se ofuscar os objetivos dos consultores por meio da dissimulação. É claro que Alberto está consciente que ele está ali para fazer mais um projeto para os indígenas. Tanto é assim que durante a entrevista, quis deixar claro que o grupo de consultores contratado tinha como tarefa principal criar os projetos que fariam parte do programa de sustentabilidade.

Programa e projeto são sinônimos para o resultado do ato de planejar algo. Semanticamente, então, elas não guardam grandes diferenças. Tanto no "projeto" quanto no "programa" o objetivo é criar planos de ação para os indígenas. No entanto, "projeto" surge na memória dos índios a partir das dores vividas e da submissão que os anula perante o poder dos "brancos". Assim, Alberto, buscando atenuar os conflitos, acha por bem seguir o conselho dos que pediram a ele para não pronunciar a palavra "projeto" e, assim, trocá-la por "programa". O que significa, apenas, uma tática para esconder as relações de poder.

A dissimulação foi uma tática comum na historiografia brasileira para esconder os reais objetivos dos colonizadores com relação aos indígenas. Muitos são os relatos de escravidão de índios tendo como justificativa a sua proteção contra os colonos, ainda que essa prática fosse considerada ilegal; era comum em nome da educação, transformá-los em trabalhadores úteis, enquadrados nos moldes ocidentais, como nos conta Pesovento (2015). Entretanto, a imposição dos planos dos colonizadores feita pela força nos primeiros momentos, hoje é principalmente baseada no estratagema e na hipocrisia, como defende Santos (2003).

Nestes casos, parte-se da tese de que os índios são ingênuos e, portanto, são facilmente enganados. A descrição dos índios como ingênuos, revela duas facetas: por um lado, os índios são vistos como seres inocentes que não foram corrompidos pela civilização; por outro, são considerados menos inteligentes e, portanto, inferiores aos civilizados "brancos". Nos dois casos, são desqualificados pelos não-índios. Diversos foram os entrevistados para este estudo que destacaram essas características nos índios. Um deles foi Alberto, que afirma: 
A ideia do fundo eles viam coisa e tal, a gente mostrava lá, ia lá, coisa e tal. A gente fazia os desenhos e explicava "o projeto tá aqui, tem esse montante que vai ficar guardado tanto como um seguro, como um fundo de seguro, como um fundo de reserva, tem um fundo aqui que vai ter as divisões". Claro que, assim, o máximo que a gente pode chegar, porque essas concepções foram paridas num mundo ocidental racional, entende? Não dá pra fazer milagres, né? É entender isso: "olha, o dinheiro de vocês vai tá aqui, guardadinho". Fazia toda uma metáfora do que era possível. Claro nós nunca tínhamos trabalhado nem com educação básica. (Alberto, consultor do programa na área de Administração)

Neste recorte se destacam as seguintes seleções lexicais: "a gente fazia os desenhos" e "nós nunca tínhamos trabalhado nem com educação básica”. Aqui, Alberto deixa transparecer a imagem infantilizada que construiu dos indígenas já que faz referência a uma prática pedagógica, os desenhos, bastante utilizada como recurso metodológico lúdico para o ensino nos anos iniciais da educação.

É interessante que Alberto passa a usar diminutivos para falar com os índios, da mesma forma como muitas pessoas falam com crianças. Neste caso, falar no diminutivo não tem qualquer relação com a redução concreta do tamanho, mas tem outros valores simbólicos. Ao usar a palavra "guardadinho", Alberto denuncia as estratégias utilizadas por ele para reduzir o risco de rejeição do seu plano junto aos índios já que dá a sensação ao interlocutor que ele iria tratar o dinheiro do fundo com carinho, já que o sufixo "inho", neste caso, tem relação com afetividade. Ademais, por serem ingênuos e possuírem baixa instrução, os índios são vistos como incapazes de lidar com as questões relacionadas ao projeto - "não dá pra fazer milagres". Desta forma, Alberto nem tenta explicar o funcionamento do projeto, mas somente o que ele considerava ser o suficiente para eles não atrapalharem: "olha, o dinheiro de vocês vai tá aqui'".

A ingenuidade dos Kaingang permite que eles sejam facilmente ludibriados pelos "brancos", pensam os envolvidos com o programa. É por isso que nas falas dos entrevistados é bastante comum encontrar seleções lexicais como "espoliar", "aproveitar", "enganar" e "ludibriar" para se referir à forma como os "brancos" tiram vantagem dos índios devido à sua ingenuidade ("pessoal muito simples", "teve índio que achou que estava rico", "índio 
comprando celular quebrado"), como podemos ver abaixo nas falas dos consultores do programa Sílvio e José:

É assim que eu via: é um pessoal simples, muito humilde, a maioria muito fácil de ser ludibriado. Algum exemplo? Olha, todos ou quase todos os aposentados lá, isso tá no relatório, tem empréstimo consignado. E não necessariamente porque precisavam de dinheiro. Eu entrevistei um que tinha poupança e pegou dinheiro consignado. Ele falou: "mas eu não queria mexer no dinheiro da poupança". A racionalidade deles é diferente da nossa. (Sílvio, consultor do programa na área de Economia)

Essa pequena porcentagem que, salvo engano foi de $20 \%$, eram 3 milhões, é isso? Acho que é isso, 20\%, que foi distribuído para as famílias, deram lá 10 mil reais, alguma coisa nessa ordem de grandeza. Então, já teve índio que achou que estava rico, largou a família e saiu com uma prostituta, foi embora, caiu no mundo, pegou o dinheiro e sumiu. O outro foi pra cidade, comprou um carro, encheu a cara e voltou pela estrada e acabou com o carro. Quase acabou com a própria vida. A aldeia foi invadida por escroques e vendedores de todos os tipos, aproveitando, sabendo que a família estava com dinheiro vivo, entendeu? Índio comprando celular quebrado. Um monte de sacanagem. Eles foram espoliados, rapidinho, daquele dinheiro. (José, consultor do programa na área de Biologia)

Esta imagem de ingênuos está tão arraigada que os consultores chegam à conclusão de que os índios foram enganados pelos "brancos" com base, na maior parte das vezes, na sua própria interpretação sobre as histórias que ouviram falar. Veja que José ignora completamente a necessidade dos índios de consumir. Será que se uma comunidade urbana pobre de não-índios tivesse recebido uma indenização como os kaingang a história seria diferente? O mesmo posso dizer sobre a fala de Sílvio que, ao falar sobre a irracionalidade econômica dos indígenas, não leva em consideração que a maior parte dos brasileiros não entende conceitos básicos de finanças pessoais ${ }^{77}$, mesmo os mais escolarizados.

\footnotetext{
${ }^{77}$ Pesquisa feita em dezembro de 2013 pelo Serviço de Proteção ao Crédito (SPC) e pela Confederação Nacional de Dirigentes Lojistas (CNDL) mostra que mais de $80 \%$ dos entrevistados, de diferentes estratos sociais, não entendem de finanças pessoais (CHIARA, 2014).
} 
Em alguns casos, a inocência se mistura à insensatez, característica daqueles aos quais faltam bom senso ou razão, como na fala de Alberto:

Os índios tinham umas coisas malucas assim. Por exemplo, tinha umas histórias muito loucas que eles iam nas oficinas... e, sei lá, tinha que arrumar um carro pra levar alguém no médico, e os caras enganavam eles e anotavam em papel de pão as peças e mandavam cobrar nas tribos. Aí, um certo dia, na reunião mensal, os índios vinham com um monte de pedaço de papel cobrando, dizendo "preciso de dinheiro pra isso aqui". Querendo pegar dinheiro do fundo. "Do fundo? Mas não pode!". (Alberto, consultor do programa na área de Administração)

Uma ação considerada maluca é uma ação imprudente, insensata, ou seja, irracional com base naquilo que é considerado correto na sociedade branca. Para Alberto, os índios, por causa da sua inocência, se tornam insensatos. Aonde já se viu querer tirar recursos do fundo para pagar gastos individuais sem ao menos uma nota fiscal que o comprove? Como "guardião" do fundo contra as ações dos insensatos índios, Alberto fica indignado. Mas será que é isso mesmo? Não poderia ser uma estratégia para acessar os recursos? É por isso que Fábio tem outra visão dos Kaingang:

Então eles sabem o que eles estão fazendo. E estão levando essa forma de relacionamento. Então eles não são simples receptores de políticas que vem de fora. Eles também traçam políticas de lidar com o outro. E, às vezes, a gente acha que nós vamos chegar lá e vamos traçar uma linha. Não. Eles têm uma linha traçada para lidar com a gente. E nós tivemos, durante todo esse tempo, vários tipos de experiência que mostraram isso. Como eles estão lidando com a gente. Eles são pessoas com inteligência que percebem o potencial que você tem ou não, para lidar com você. (Fábio, consultor do programa na área de Antropologia)

Como pesquisador, Fábio tem uma relação antiga com os Kaingang, tendo trabalhado com eles desde 1996. É assim que ele percebeu que os índios são mais estratégicos (“eles têm uma linha traçada para lidar com a gente") do que pensa a maioria dos "brancos". Assim, até mesmo a imagem de inocentes pode ser uma estratégia levado a cabo pelos índios para conseguir alcançar seus próprios objetivos. Utilizando a imagem criada pelos "brancos" de 
índios como ingênuos, inocentes e até insensatos, pode lhes permitir certo equilíbrio nas relações de poder, já que o enfrentamento não é uma boa tática frente ao grande poder (étnico, econômico e cultural) dos não-índios.

José me descreveu uma história que aconteceu com ele em Apucaraninha que pode exemplificar bem isso:

Inúmeras vezes a gente foi capturado, entre aspas, por grupos. Foi usado como uma massa de manobra por eles para agredir o outro grupo, entendeu? Antes de você perceber isso você acaba fazendo um monte de besteira, sabe? Por exemplo, você chega lá na maior boa vontade, com o projeto, fala: “então, vamos plantar os pinheiros que vocês querem. Onde vai ser esse plantio?”. “Ah, vai nessa terra aqui”. "Por que aqui?”. "Não, porque aqui é o lugar que tem que ter pinheiral". "Mas, ah, essa terra aqui está limpinha, está planinha, você não quer guardar para fazer agricultura?". "Não, não, vai ter que ser aquil. Depois, passa um tempo, você descobre que a plantação de pinheiro é ali porque tinha um outro que estava reivindicando aquilo pra agricultura. Até você se tocar da besteira que você fez... Aí você pede: "me ajuda a identificar trabalhadores aí que vão trabalhar no reflorestamento, para campinar as mudas, ajudar plantar, ajudar colher, que a gente tem uma grana aqui para pagar diária dessas pessoas que vão ajudar a gente no projeto". Beleza, aí vem todo mundo de uma família só, entendeu? E o outro, que você tinha contato, que você tinha expectativa que fosse indicado e que também tinha expectativa de ser indicado para o trabalho, não foi. Aí é outro que você arrumou de inimigo, que passa a te detestar. Um dia ele toma uma pinga a mais e passa no reflorestamento e põe fogo no reflorestamento. $\mathrm{O}$ reflorestamento queimou 10 dias. Então, assim, a gente foi capturado por uma família. Todo mundo que a gente contratou foi, até cair a ficha. (José, consultor do programa na área de Biologia)

Quando José diz que vai "na maior boa vontade" com seu projeto de reflorestamento para ajudar os índios, ele demonstra se sentir traído quando foi "capturado" por eles. Afinal, ele estava indo à aldeia para ajudar e não para ser apreendido como um conquistador despreparado dos séculos passados. 
Entretanto, usando a imagem que os "brancos" têm deles como pessoas ingênuas e irracionais, os índios conseguem fazer com que ele agisse conforme desejavam. É claro que José achou estranho estarem usando uma terra propícia à agricultura para reflorestamento. Mas, pensa ele, como nem tudo o que fazem têm explicação no "mundo racional dos brancos", resolveu acatar. Até mesmo ações como as do índio que botou fogo no pinheiral são suavizadas, já que são o resultado de mentes inocentes e insensatas.

Os estereótipos tornam as pessoas invisíveis porque as tomam a partir de falsas imagens homogeneizadas. E quando elas teimam em aparecer, se tornam um incômodo, já que não cabem nos modelos pré-definidos. Foi o que aconteceu com os não-indígenas inseridos em Apucarinha para o desenvolvimento do programa de sustentabilidade. É o que podemos ver em outro recorte feito nas palavras de Sílvio, que fica confuso ao se deparar com o índio de carne e osso:

É outra cultura. Eles tem uma outra forma de ver o mundo. Daí que os mais novos são muito mais parecidos com a gente. Posso te falar uma coisa curiosa? Eu também fazia uma série de perguntas sobre a questão de alimentação. Sabe quem é que gosta de comer a comida típica indígena? Os brancos! Eles comem o que a gente come. Eles comem mandioca, eles comem um pouco... Eles pescam da mesma forma que a gente pesca. Eu vi uma fotografia de um pari que a aquela pesquisadora da UEL tirou a fotografia. Mas assim, ela pagou pra alguém construir aquilo. Porque aquilo não é mais prática. É mais fácil pegar um anzol e linha pra eles pescarem. Eu vi todo mundo pescando de vara. Então, toda aquela parafernália lá, feito de bambu... Tudo aquilo lá eles não usam mais. Mas tem uma pessoa lá que sabe fazer e se enche daquilo, entende? Mas não é uma prática deles pescarem com aquilo. A prática deles pescarem é com anzol, minhoca, está certo? Então, assim tem muitos. Eu não posso dizer que a cultura deles é uma coisa que não existe mais. Existe uma mistura que a gente não sabe direito o que é agora, mas tem uma mistura. Mas não são exatamente iguais a gente. Não é a mesma cultura que os livros trazem. E não é a nossa. Eles têm o estilo deles, que é dos indígenas do capitalismo. (Sílvio, consultor do programa na área de Economia) 
Por não se encaixarem na imagem idealizada dos indígenas, são considerados aculturados e não dignos de serem "protegidos" ${ }^{, 78}$. Ele se irrita porque não encontrou o índio idealizado por ele com a ajuda dos livros, já que o índio de Apucaraninha, em sua opinião, possui práticas consideradas de sociedades civilizadas, coisa totalmente contrária ao que ele esperava encontrar em uma terra indígena, primitiva e com costumes "atrasados". Sobre isto, Arruda (2001, p. 48) escreve:

O fato de que os povos indígenas não se conformam exatamente a estes modelos idealizados, faz com que os índios efetivamente existentes sejam vistos com desdém, irritação e uma ponta de acusação, algumas vezes até mesmo por seus próprios defensores. Isto é, sejam vistos como "não índios", ou índios “descaracterizados”, “deculturados”, “vendidos”, a ponto de não merecerem o esforço que se faz por eles.

Sílvio os acusa de não serem mais índios, apesar de também aceitar que eles não são "brancos”. Se não são mais índios e não são "brancos”, são o quê? Sílvio utiliza o discurso do colono com ascedência europeia que habita as regiões vizinhas aos Kaingang. Para os colonos, "esses índios não são mais índios; tampouco seriam brancos, não passando de uns “caboclos"”, lembra Fernandes (2000, p. 777). Como os negros das Antilhas, envoltos por uma sociedade branca considerada superior, os indígenas foram colocados "na zona de nãoser, uma região extraordinariamente estéril e árida" (FANON, 2008). Se eles não são índios porque comem os mesmos alimentos dos "brancos", pescam como eles e são capitalistas. Por que, então, não são considerados "brancos"? Para a manutenção de seu poder baseado na superioridade, torna-se necessário se esquivar da semelhança (BHABHA, 1998). Trata-se, assim, da exclusão total dos indígenas.

Se ainda fossem índios, saberia como lidar com eles, posto que suas estruturas mentais estavam prontas para lidar com o índio imaginário. Para Freire (2002, p. 12), esta é uma das ideias equivocadas que muitos brasileiros ainda têm sobre os índios:

Enfiaram na cabeça da maioria dos brasileiros uma imagem de como deve ser o índio: nu ou de tanga, no meio da floresta, de arco e flecha, tal como

\footnotetext{
${ }^{78}$ Ainda hoje é comum ouvir pessoas afirmando que os índios não precisam de tanta terra, já que não são mais índios. A fala da ministra da agricultura, Kátia Abreu, de que "os índios saíram da floresta e passaram a descer nas áreas de produção" (BERGAMO, 2015), em janeiro de 2015 ao jornal Folha de São Paulo, espelha bem isso.
} 
descrito por Pero Vaz de Caminha. E essa imagem foi congelada. Qualquer mudança nela provoca estranhamento. Quando o índio não se enquadra nessa imagem, vem logo a reação: "Ah! Não é mais índio". Na cabeça dessas pessoas, o índio "autêntico" é o índio de papel da carta do Caminha, não aquele índio de carne e osso que convive conosco, que está hoje no meio de nós.

A compreensão de Sílvio sobre o conceito de cultura é a de traços culturais que, assim, podem ser perdidos ou tomados de empréstimos de outras populações. Essa corrente de pensamento defende que um povo, especialmente os não-ocidentais, considerados primitivos, está sujeito a perda regressiva da sua cultura. O que nos leva à noção de aculturação. Para Cohn (2001) esta ideia já foi superada. Hoje, o conceito de cultura não está ligado a traços culturais, mas a noção de fronteiras culturais, ou seja, pela atribuição de diferença entre populações. Desta forma, uma cultura não é perdida, mas é constantemente reconstruída.

Assim, o congelamento da cultura indígena (FREIRE, 2002) desejado por Sílvio para caracterizar os índios Kaingang, não tem como existir. E Sílvio fala isso com base apenas nas práticas que ele consegue ver. Ao refletir em seu discurso que a cultura dos índios é diferente da dos "brancos", ele faz a refração para dizer que eles evoluíram ("os mais novos são muito mais parecidos com a gente"), pois deixaram práticas consideradas tradicionais, como pescar em pari, por outras mais eficientes, pescando com vara e anzol e, portanto, não são nem índios e nem "brancos", mas "índios capitalistas", "aculturados" pelos costumes da sociedade envolvente. Trata-se de um projeto civilizador.

Continuam, portanto, sendo "o outro", o diferente de "nós", só que agora um "outro" desconhecido, que Sílvio busca classificar. Para Silva (2000), dividir é o mesmo que classificar. E classificar é uma forma de hierarquizar, implicando a formação de relações de poder. Assim, dividimos os mundos sociais em grupos atribuindo diferentes valores a eles conforme nossa visão particular, privilegiando um sobre o outro e, desta forma, criando um padrão pelos quais as diferentes sociedades são avaliadas.

Agora, os índios são "o outro" indefinido ("existe uma mistura que a gente não sabe direito o que é agora") - pois não são os civilizados "brancos", nem tampouco os primitivos índios - já que, aos seus olhos, uma das principais características da sociedade envolvente, o capitalismo, 
eles já incorporaram ${ }^{79}$. Forma-se um outro "outro" nesta relação, além do "outro" índio nasce o "outro" indefinido, o ex-índio, "uma nova categoria, desconhecida pela etmologia", como afirma Freire (2002, p. 12). O “outro" indefinido transforma o indígena em uma incerteza, uma presença parcial, incompleta e virtual, defende Bhabha (1998) em outro contexto.

Outro consultor que faz uma forte distinção entre o modo de vida dos "brancos" e dos índios é Alberto, que diz:

Quando eles vêm pra cá eles ficam nos semáforos. Isso é terrível! Porque a prefeitura de Londrina tem uma área que cuida de índios. Então, quando eles saem de lá e vem pra cá é o problema. Acho que foi a professora de antropologia da UEL que falou no projeto, eu não lembro agora, que quando eles vêm para o semáforo eles estão fazendo uma coisa que faziam há centenas de anos. Ou seja, que era vir para caçar, que era o ritual de atravessar. Eles não vêm mendigar, eles vem à caça em um outro sentido, à caça do sustento. Então, eles vêm com os balaios. Para eles isso é uma aventura, não é um problema, sabe, só pelo dinheiro. Então, para eles têm um outro significado. Para nós é: "pô, os mendigos vêm com essas crianças... e índios pedindo coisa no semáforo, coisa e tal”. É algo que é um outro contexto. Eles estão percorrendo territórios que sempre percorreram. Então, há obviamente uma luta por espaço, uma luta que assumiu várias formas e que neste exato momento a forma que eles conseguiram foi da forma pedinte, né? (Alberto, consultor do programa na área de Administração)

$\mathrm{Na}$ fala de Alberto chama a atenção à clara oposição entre o "mundo dos brancos" e o "mundo dos índios". Isso pode ser visto nas seleções lexicais "eles vêm pra cá", “área que cuida dos índios", "vêm para o semáforo", "ritual de atravessar", "vêm à caça" e "luta por espaço". Podemos ver aqui um desejo, mesmo que inconsciente, de segregar, de separar e organizar as pessoas por meio de um marcador étnico, como meio de manter a paz social, já que quando os índios vêm para Londrina é "terrível”, um “problema”, como afirma Alberto.

Tommasino (2000) nos lembra que mesmo sendo presos a espaços delimitados, como nas reservas e nas terras indígenas, os índios insistem em aparecer. Assim, ocupam os espaços que

\footnotetext{
${ }^{79}$ Como vimos em um trecho anterior, Sílvio chega a essa conclusão também a partir do consumo.
} 
os "brancos" acreditam que é exclusivo deles. Afinal, lugar de índio é na aldeia. Resistem, portanto, a uma vida sedentária e a um poder tutelar que ainda hoje insistem em impor a eles.

A vida nas reservas obriga os Kaingang a moverem-se no e sobre o espaço do branco. Mesmo negado na sua especificidade, ele ressurge borrando esse espaço com sua territorialidade kaingang. Dialeticamente, o processo indígena se (re)inscreve no mundo dos brancos (TOMMASINO, 2000, p. 223).

Ao invadirem os "espaços dos brancos" os índios enfeiam as cidades ("isso é um problema") com suas barracas de lona e sua presença nos semáforos, que muitas vezes é confundida com os sem-teto ou com os mendigos. Sem ter onde ficar, já que a Centro Cultural Kaingang nomeado em kaingang como Vãre - citado por Alberto, não está mais em uso ${ }^{80}$, os índios que vêm à Londrina para vender seus cestos ocupam os terrenos baldios, principalmente onde estava localizado o Vãre, com barracos improvisados, durante sua permanência na cidade.

Como os miseráveis, os indígenas mancham a paisagem urbana que se pretende impecável, a altura dos altos padrões da mercadoria-cidade reservada a uma elite que pode pagar por ela (HARVEY, 2012; VAINER, 2000). Nesta cidade, os pobres são tolerados, já que para seu funcionamento é necessário o trabalho dessa classe social. Mas, bem entendido, só são tolerados aqueles que contribuem para a ordem social. Mas, esta ordem teima em ser rompida por "gente diferenciada" ${ }^{81 ", ~ c o m o ~ o s ~ m e n d i g o s ~ e ~ o s ~ i n d i ́ g e n a s ~(m u i t a s ~ v e z e s ~ c o n s i d e r a d o s ~ a s ~}$ mesmas pessoas $^{82}$ ), que não trabalham e, portanto, não colaboram com esta pretensa ordem.

Alberto se insere em um contexto - "para nós" - em que a visibilidade dos índios é um problema, uma vez que são vistos como mendigos, que caçam para seu sustento. A referência à caça, uma das mais antigas atividades humanas, não é gratuita. A caça hoje é vista como

\footnotetext{
${ }^{80}$ Em 2013 o Ministério Público Estadual pediu a desocupação do local onde estava instalado o Centro Cultural Kaingang desde 1999, por ele ter sido construído em um fundo de vale. A promessa de construção de uma nova Casa de Passagem para os kaingang ainda não foi cumprida.

${ }^{81}$ Em uma matéria da Folha de São Paulo sobre a mobilização de alguns moradores de Higienópolis, bairro nobre de São Paulo, contra a instalação de uma estação do Metrô na região, uma das moradores deu o seguinte depoimento ao jornal: "Eu não uso metrô e não usaria. Isso vai acabar com a tradição do bairro. Você já viu o tipo de gente que fica ao redor das estações do metrô? Drogados, mendigos, uma gente diferenciada..." (CIMINO, 2010, s/p, grifo meu).

${ }^{82}$ Em 1997, um grupo de adolescentes pertencente à classe média alta ateou fogo e matou o índio Pataxó Galdino Jesus dos Santos que estava dormindo em um ponto de ônibus em Brasília. Indagados sobre os motivos do crime, um deles disse que não sabiam que era um índio, acharam que era "só" um mendigo.
} 
uma atividade primitiva. A mudança do modo de vida, de caçador e criador de animais, é considerada uma evolução na história mundial. Na caça, não há preocupação com a eficiência, com o produzir mais em menos tempo. Alberto ainda tenta passar a imagem de que compreende de outra forma a presença dos índios na cidade citando uma antropóloga ("acho que foi a professora de antropologia da UEL que falou no projeto, eu não lembro agora, que quando eles vêm para o semáforo eles estão fazendo uma coisa que faziam há centenas de anos"). Ao alterar o sujeito, trazendo outro para a argumentação, ele tenta dar provas de que não vê a passagem dos índios com preconceito. Entretanto, ao colocar em oposição à forma como os índios e os "brancos", inclusive ele, interpretam esse acontecimento, Alberto acaba reforçando a ideia de segregação em nome da boa convivência entre eles, já que vivem em mundos diferentes, como já dito.

Lembrei-me agora do que ouviu Goulart (2011, p. 21) dos técnicos da FUNAI quando do acampamento de índios Kaingang na Praça Ângelo Kretã na zona norte de Londrina entre 2009 e 2011:

\footnotetext{
"Se a FUNAI apoiar esse movimento, nós estaremos apoiando a baderna, não concorda?”. Outro logo em seguida, completou tal raciocínio dizendo, "seria tudo mais fácil se eles aceitassem voltar para a aldeia. Não é objetivo da FUNAI esvaziar as aldeias".
}

A segregação está intimamente ligada à ideia de controle. Se eles aceitassem voltar pra aldeia estaria garantida a paz social. Nada de baderna, de confusão no espaço urbano promovido pelos índios, já que a sua simples presença traz desconforto. Outhwaite e Bottomore (1996) afirmam que a segregação é muitas vezes aceita em nome da paz e da harmonia social. Assim, escrevem:

Os proponentes dessas idéias negariam peremptoriamente que são racistas: classificam diferenças de humanidade, mas sem afirmar a superioridade ou inferioridade de diferentes categorias, meramente a conveniência de sua segregação (OUTHWAITE; BOTTOMORE, 1996, p. 644).

Mas, no fundo, o que ele está querendo dizer é que uma etnia é superior à outra e que o índio, por ser atrasado, deve ser protegido de si mesmo. Isso fica claro quando Alberto cita a "área 
que cuida de índios" na cidade. Cuidar é um verbo vinculado à assistência a alguém, ao tomar conta de/para alguém e, portanto, tem efeito de sentido de assumir a responsabilidade por outro. Cuidamos de alguém que não pode cuidar de si mesmo. Neste caso, legitima as ações de tutela.

O que motivou a criação do Programa de Desenvolvimento em Apucaraninha foi a ideia disseminada entre os não-indígenas de que os índios não sabem lidar com dinheiro. É por isso que na Ata da reunião ocorrida em 2006, quando se definiu o valor da indenização, já consta que $80 \%$ do montante seria liberado conforme os projetos selecionados para compor o Programa de Sustentabilidade Socioeconômica e Ambiental (MPF, 2006). Somente 20\% da indenização foi entregue diretamente às famílias de Apucaraninha para que gastassem no que desejavam. Isso depois da insistência das antropólogas do Ministério Público Federal e da Universidade Estadual de Londrina ao Procurador da República. Carlos defende a atitude do Ministério Público Federal:

\begin{abstract}
A gente entende a condição do Ministério Público. Porque se ele não fizer isso, ele vai ser cobrado pela sociedade em pegar um recurso dessa magnitude, naquela época, e dar pra população e ela acabar com tudo para pedir dinheiro de novo. (Carlos, consultor do programa na área de Agronomia)
\end{abstract}

Carlos vê os índios como irresponsáveis que necessitam da condução de um tutor. O tutor dos índios hoje, para Carlos, é o Ministério Público, que tem obrigação moral de controlar os índios. A mim fica a sensação de que, até certo ponto, restituem-se as condições do antigo poder tutelar ${ }^{83}$, em que os índios são infantilizados e disciplinados por um tutor.

Aqui, os índios são infantilizados quando são retratados, mesmo que de forma implícita, como crianças que ao acabar com a mesada antes do prazo exigem mais dos pais (“acabar com tudo para pedir dinheiro de novo.”). Afinal, o dinheiro da indenização é considerado por Carlos como uma mesada que os "brancos" deram aos índios e não como uma indenização legítima para reparação dos danos causados pela usina hidrelétrica. Como pais zelosos, o Ministério

\footnotetext{
83 Apesar de hoje superado nos textos legais, o poder tutelar foi instituído no começo do século XX para demarcar as relações entre "brancos" e índios. Nesta acepção, os indígenas são equiparados aos não-índios menores de 18 e maiores de 16 anos, ou seja, dado que não são totalmente responsáveis por suas ações são conduzidos por um tutor (LIMA, 2010).
} 
Público, na visão de Carlos, deve conduzir as ações dos índios, já que toda criança precisa - e pede - o controle de seus pais. Justifica-se a tutela, portanto. Para Memmi (1979, p. 79), "quando o colonizador afirma, em sua linguagem, que o colonizado é um débil, sugere com isso que tal deficiência reclama proteção". O trecho abaixo espelha bem essa ideia:

Você não podia correr o risco de dar dinheiro para o índio. Este era o grande medo de todo mundo: ele torra em três dias. Tudo bem, vamos lá, foda-se. Alguém poderia dizer, tudo bem, isso é uma proposta política, é pau em três dias, entende? É isso. Eles falavam isso: o dinheiro precisa circular. Então, eles não olham em linha reta igual nós homens racionais. Então, é isso que eu diria pra eles: o dinheiro ia voltar, eles iam ter novo. Então, esse era o trabalho difícil. Nós tínhamos que apresentar um programa apontado em uma linha reta para os caras. Eles tinham que entender porque tanto dinheiro parado lá para fazer poupança, para alavancar algumas coisas. (Alberto, consultor do programa na área de Administração)

Para Alberto, os índios são o oposto dos "brancos", nos quais ele se inclui ("nós"): enquanto os "brancos" são racionais e pensam o uso do dinheiro a partir do planejamento ("linha reta") e dos custos e benefícios ("poupança” e "alavancar"), os índios são irracionais, pois "torram” o dinheiro "em três dias" e, assim, não pensam no futuro.

Tendo esta "deficiência", os índios precisam da tutela dos "brancos" para fazer o dinheiro da indenização render, como deve ser quando falamos de recursos financeiros. Na racionalidade "branca", dinheiro não foi feito para ser gasto à toa. É preciso ter um plano para ele, levando em conta o melhor custo-benefício, ou seja, observando os critérios de economicidade. É claro que não entra nesta conta questões relacionadas às diferenças culturais, às normas tradicionais e aos desejos.

A mesma lógica fez com que Rezende (1999, p. 15, grifo do autor) se sentisse incomodado pela forma com que os assentados que utilizam os recursos do PROCERA, Programa de Crédito Especial para Reforma Agrária, criado com o intuito de aumentar a produtividade agrícola nos assentamentos, permitindo "a inserção do assentado no mercado em geral e no mercado financeiro em particular e, assim, torná-lo independente da tutela do Estado, com sua 'emancipação"”. 
Para ele, o PROCERA, ao invés de melhorar as condições de produção e a inserção dos assentados no mercado, somente aumentou o valor do "patrimônio doméstico" consubstanciado na significativa aquisição por parte dos assentados em fogão, geladeira, televisão, armários etc. - e do número de animais para consumo, "principalmente de pecuária leiteira e suínos, atividades que geram pouca renda monetária" (REZENDE, 1999, p. 15). Para este autor, isso se torna desperdício de recursos, uma vez que não são reinvestidos na economia capitalista. Não só o valor financeiro disponibilizado pelo PROCERA, mas também da terra, recurso que deve ser usado racionalmente para fazer dinheiro. A lógica do assentado de adquirir animais para prover a sua subsistência e de sua família é desprestigiada. Forma, aliás, predominante na maior parte da história mundial, como nos informa Polanyi (2000).

A lógica de Rezende (1999) é a mesma de Alberto: está relacionada aos valores instrumentais, puramente econômicos, totalmente alinhada à velha ideia iluminista de razão que leva ao progresso (ADORNO; HORKHEIMER, 1999). Nascida no iluminismo, a racionalidade utilitária leva em conta o cálculo entre os fins e os meios. O sujeito liberal, que surge das ideias de Descartes, é um ser "liberto de quaisquer raízes [,] independente de tudo que estava fora dele, inclusive os ecossistemas de seus ambientes", e por isso torna-se racional. As tradições, os lugares, nada o desvia dos caminhos da razão (GRÜN, 2006, p. 71), justificando até a dominação dos não-civilizados.

Mas, nem todo índio era imaturo e difícil de controlar. O índio em condição de assimilado era aquele considerado "legal", "tranquilo" "carismático", "maduro" e "racional", porque parecia pensar como o "branco". É assim que os consultores descreviam os índios vistos como assimilados com palavras mais positivas, como podemos ver na fala de Alberto:

Tinha gente muito legal. Esse cacique que estava lá, não sei se está lá ainda, ele era um cara muito tranquilo, carisma... Se não me engano foi ele que falou para a gente antes que não queria que distribuísse o dinheiro porque o índio ia gastar. Então eu acho muito interessante. Você sentia que tinha pessoas que estavam num nível de maturidade, de compreensão que era uma grande oportunidade para eles, por exemplo. (Alberto, consultor do programa na área de Administração) 
Ao citar uma das lideranças como madura o suficiente para entender que estavam frente a uma grande oportunidade, ou seja, de melhorarem de vida com a ajuda dos "brancos", podemos identificar um discurso de colonizador que classifica os índios como mansos ou bravios, conforme sua aptidão para colaborar com os invasores ${ }^{84}$. "As melhores intenções podem encobrir relações assimétricas e discursos de dominação permeados por estereótipos pejorativos quanto ao "índio"”, afirma Baines (2000, p. 147). É por isso que muitos indígenas, para fugirem do preconceito e serem tratados como "gente" pelos "brancos", preferem passar a imagem de "índio civilizado" que aderiu aos valores urbanos e desenvolvimentistas.

O que não significa, contudo, que este índio fosse visto como um igual, já que, da mesma forma que os colonizados africanos, "no plano social ele permanecia sempre um membro subalternizado, nunca visto pelos colonos como 'um de nós' e sempre como 'o mais civilizado deles"” (CABAÇO, 2009, p. 118). O assimilado surge como um modelo ideal no meio de uma massa homogeneizada de um povo atrasado, como veremos no próximo capítulo.

\footnotetext{
${ }^{84} \mathrm{Na}$ historiografia é comum encontrarmos narrativas sobre caciques que se aliaram aos "brancos" e ajudaram na conquista dos grupos que ainda resistiam ao contato com os índios.
} 


\section{$7 \quad$ O ÍNDIO ADMINISTRADO}

A ideologia do management não tem como prosperar em uma sociedade que possui como valor norteador de suas práticas o comunitarismo e uma racionalidade não utilitarista, uma vez que o discurso do management pressupõe outros discursos que o precedem, como o discurso capitalista.

Neste capítulo, tenho como objetivo discorrer sobre dois destes discursos: o discurso do colonizador, que desqualifica a forma de vida dos índios, e o discurso capitalista, que legitima as relações baseadas no mercado e no consumo, além de elevar os seres utilitaristas e autorrealizados, prometendo o sucesso e a liberdade.

\subsection{O "branco" que não venha falar que o índio é diferente}

Hoje, não é mais preciso que o colonizador se desloque fisicamente para exercer seu domínio. Basta que sua ideologia, por intermédio do discurso do colonizador que marca as diferenças, interpele os colonizados, os fazendo acreditar que a sociedade "branca" é superior e que, portanto, suas práticas indígenas devem ser superadas porque espelham o atraso. Por ser uma força que age na subjetividade das pessoas, trabalhando com o fetichismo ${ }^{85}$, se torna ainda mais poderosa.

Começo a sofrer por não ser branco, na medida em que o branco me impõe uma discriminação, faz de mim um colonizado, me extirpa qualquer valor, qualquer originalidade, pretende que seja um parasita no mundo, que é precise que eu acompanhe o mais rapidamente possível o mundo branco. [...] Então tentarei simplesmente fazer-me branco, isto é, obrigarei o branco a reconhecer minha humanidade (FANON, 2008, p. 94).

O negro, que anseia por embranquecer - porque é assim forçado pela pretensa superioridade da sociedade branca, pois "para o negro, há apenas um destino. E ele é branco” (FANON,

\footnotetext{
${ }^{85} \mathrm{O}$ fetichismo pode ser descrito como uma fantasia que surge com o desejo, ou melhor, uma ilusão que conforma a consciência humana, ou seja, sua subjetividade, define Kehl (2004) relacionando os conceitos de Marx e Freud.
} 
2008, p. 28) - está nesta zona, em que nega sua negritude, pois ela é inferior, mas, ao mesmo tempo, não se torna um branco, já que a cor da sua pele o denuncia. Da mesma forma que o negro se torna negro pelo olhar deslocador do branco, o índio se torna índio pelo olhar da sociedade envolvente. O Escritor e Doutor em Educação, Daniel Mundukuru, da etnia Munduruku, ao participar de um bate-papo com os visitantes da $23^{\mathrm{a}}$. Bienal do Livro em São Paulo contou que só foi se descobrir índio na escola.

Eu descobri que era índio quando fui à escola pela primeira vez. Antes disso, as pessoas me chamavam pelo nome. Quando cheguei na escola, onde usei roupas pela primeira vez - uniforme, farda, fardo - alguém gritou: “- Olha o Índio!”, e eu fiquei procurando. Na escola, descobri que o que era diferente era tratado com inferioridade. Era como se a gente nascesse errado, e a escola tivesse que nos consertar. Mudar o cabelo, mudar a cor da pele. E isso era tão forte, que eu não queria mais ser índio. Não queria mais ser Mundurucu. Eu queria ser branco (MUNDUKURU, 2014 apud SESC-SP, 2014, s/p).

É assim que o colonizador se torna fonte de inspiração para a forma de ser e viver dos indígenas, acionando a imitação. Uma mímica, no entanto, de caráter ambivalente, já que resulta em "um Outro reformado, reconhecível, como sujeito de uma diferença que é quase a mesma, mas não exatamente" (BHABHA, 1998, p. 130, grifo do autor). Este jogo de imitação é descrito por Marcelo, que trabalhou no programa de sustentabilidade na Terra Indígena Apucaraninha:

Eles se sentem marginalizados. Então, algumas coisas eles querem para se sentir pertencente ao mundo do branco. Tem que ser igual a eles não podem ficar de fora. Então, um fetiche, uma expectativa de igualdade. Eu sou índio, estou mobilizado, todos os meus parentes, temos a briga no plano nacional, no plano estadual, no plano municipal... Eles estão entendendo o elemento macro. Mas ao mesmo tempo eles chegam na cidade e são marginalizados, estão no escanteio porque o tênis não sei o que, porque a roupa... E eles não querem se sentir marginalizados. Eles não querem ficar pra trás nisso. Então é a juventude, é a questão de maturidade, de todo um contexto, com essa revolta e energia que eles têm. (Marcelo, sociólogo, facilitador de campo durante o programa) 
Para Marcelo, apesar de exibirem orgulhosamente sua indianidade ("eu sou índio, estou mobilizado, todos os meus parentes") quando estão com seus pares, a "superioridade branca" exerce uma força bastante intensa sobre suas vidas (“eles se sentem marginalizados”). Esse comportamento, que Marcelo trata como contraditório, está muito claro para mim quando o interpreto a partir do olhar de Honneth (2003).

Os jovens kaingang passam pela "vergonha social", uma vez que, como vimos no capítulo anterior, são vítimas do preconceito da sociedade envolvente que os vê como um povo indolente, atrasado e ingênuo, entre outros predicativos frutos de uma imagem homogeneizada. Honneth (2003) lembra que, para Hegel e Mead, os sujeitos precisam, além do reconhecimento amoroso e do reconhecimento jurídico, ser estimados pela sociedade. Essa estima social os permite se autorreconhecer e, assim, se autoestimar.

Esse reconhecimento social depende de como a pessoa é vista pela sociedade como apta a colaborar com a realização dos objetivos sociais pré-determinados. Como escreve Honneth (2003, p. 201):
A eticidade convencional dessas coletividades permite estratificar verticalmente os campos das tarefas sociais de acordo com sua suposta contribuição para a realização dos valores centrais, de modo que lhes podem ser atribuídas formas específicas de conduta de vida, cuja observância faz com que o divíduo alcance a "honra" apropriada a seu estamento.

Advém daí a busca angustiante dos jovens kaingang para se adequar às normas da sociedade envolvente, nem que seja se vestindo como eles, com o objetivo de se sentirem iguais a eles. No entanto, como a "honra" $" 86$ é uma medida pré-determinada conforme o estamento que a pessoa ocupa, essa tentativa de mimetismo dos índios ao modo de vida dos "brancos" é infrutífera. Como o estamento que eles ocupam já foi designado conforme a ordem de valores da sociedade, não adianta, então, os índios tentarem se transformar em "brancos" para angariar prestígio social, dado que não serão as roupas que irão esconder a sua origem étnica.

\footnotetext{
${ }^{86}$ O conceito hegeliano de "honra" foi, com o tempo, substituído por "reputação" ou "prestígio". No entanto, o significado continua inalterado, sendo que "prestígio" e "reputação" são adquiridos socialmente da mesma forma que a "honra": na participação prática no alcance dos objetivos da sociedade (HONNETH, 2003).
} 
É desta forma que, para tentar sair dessa situação paralisante que os índios se unem aos seus pares nos movimentos indígenas, uma vez que ali se sentem estimados, pois como a ordem dos valores passa a ser outro e os jovens que participam do movimento indígena são bem vistos pela comunidade, ascendem na hierarquia estamental.

O engamento nas ações políticas possui para os envolvidos também a função direta de arrancá-los da situação paralisante do rebaixamento passivamente tolerado e de lhes proporcionar, por conseguinte, uma auto-relação nova e positiva. A razão dessa motivação secundária da luta está ligada à própria estrutura da experiência de desrespeito. Na vergonha social viemos a conhecer o sentimento moral em que se expressa aquela diminuição do autorespeito que acompanha de modo atípico a tolerância passiva do rebaixamento e da ofensa; se um semelhante estado de inibição da ação é superado agora praticamente pelo engajamento na resistência comum, abrese assim para o indivíduo uma forma de manifestação com base na qual ele pode convencer-se indiretamente do valor moral ou social de si próprio [...] (HONNETH, 2003, p. 259).

Talvez entre os índios mais afastados das áreas urbanas, onde há pouca convivência com os "brancos", seja mais fácil reafirmar as diferenças, como ocorre com algumas aldeias da Amazônia. Mas, em Apucaraninha, as cidades estão a poucos quilômetros, havendo um contato grande entre os índios e a sociedade envolvente. Neste caso, demarcar uma diferença não faz muito sentido para eles, pelo menos perante os "brancos". Assim, eles querem se sentir pertencente ao "mundo dos brancos", me lembra um dos entrevistados enquanto me conta sobre a visita de alguns jornalistas à comunidade:

$\mathrm{Na}$ época do diagnóstico teve um jornalista que foi lá pra fazer entrevista com indígenas e tratar sobre a alimentação tradicional. E eu estava lá com os índios e todo mundo comentando, eu gosto muito daquilo lá, daquilo, daquilo, daquilo, e eu como as coisas dos brancos, eu só como as coisas dos índios... Aí ele foi se apresentar para o pessoal que só come alimento indígena e perguntou: "aí, o que você come?" “Arroz, feijão, frango e macarrão". O jornalista foi embora. "O branco não vem falar o que eu como. Eu como igual você. Eu visto o que você veste. Eu vejo na televisão o que você vê". É mais uma coisa de se sentir pertencente. A festa. A festa que eles 
fazem com o rodeio, shows, tratores sendo expostos na festa do índio esse ano. Eles estão disputando com a festa agropecuária de Londrina. Eles querem ser iguais a você. Eu não quero que você me olhe como um inferior. E isso está neles. (Marcelo, sociólogo, facilitador de campo durante o programa)

$\mathrm{Na}$ aldeia, os kaingang podem até demarcar as diferenças entre eles e os "brancos", mas quando estão frente a frente com os não-índios, não querem ser vistos como diferentes. No espaço administrado, só deixam transparecer seus "traços" indígenas possíveis, aqueles que são aceitos pela sociedade nacional. É só na "clandestinidade" que sua especificidade cultural, que é representada por uma visão de mundo particular, pode ser observada (TOMMASINO, 2000). Trata-se da necessidade que eles sentem de, frente ao "branco", não serem vistos como inferiores. Por anos foram forçados a crer que o modelo a seguir era o do "branco", já que ser índio era estar fadado ao fracasso, aos trabalhos subalternos e a pobreza, enquanto viam seus vizinhos não-índios adquirindo bens e vivendo uma vida de mais opulência. Sendo assim, o seu ideal de futuro está em se parecer, o mais possível, com o "branco".

Em uma sociedade capitalista, os bens vivem nas pessoas como "representações subjetivas" (SIMMEL, 1977), repletos de significações, sendo um deles servir como passaporte para um mundo desejado. Os kaingang de Apucaraninha veem nos bens formas de se aproximar da sociedade envolvente e, assim, se sentirem mais iguais. Assim, desejam televisores de tela plana, celulares, computadores, móveis, veículos e tratores da mesma forma que os "brancos".

Bom, a dinâmica deles sempre é em relação ao entorno. Então o que acontecer no entorno, eles vão se adequando. É logico, os mais velhos com a tradição mais antiga vão falecendo e vão aparecendo os mais jovens, que vai tentando adaptar o mundo externo ao mundo interno, mas eles vão continuar lá. Porque eles nascem Kaingang. Então a cultura deles permanece, o espaço físico deles permanece. O que você vai ter são as adaptações que ocorrem devido ao próprio entorno. A questão do celular, hoje os índios usam celular e ele não usava 20 anos atrás. Porque não existia! Então, nós não sabemos o que virá de tecnologia que ele vai buscar. [...] Se eles vão querer continuar ser Kaigang, aí isso é com eles. Se você perguntar pra mim se eu tenho que comer polenta todo dia na hora do almoço: eu odeio polenta! E não é por 
isso que eu vou comer polenta só porque eu sou neto de italiano. (Carlos, consultor no programa na área de Agronomia)

A indenização recebida da COPEL foi o primeiro momento em que se sentiram invejados pelos "brancos", já que para a população da cidade vizinha, Tamarana, os índios de Apucaraninha estavam ricos agora, como já vimos anteriormente. Assim, começaram a se sentir importantes e parte da sociedade quando os comerciantes passaram a tratá-los como gente, não importando para eles se esta diferença no tratamento tinha somente relação com o seu recém adquirido poder de compra. Agora eles são recebidos e bem tratados pelos comerciantes, nos bancos e até nos órgãos públicos. Podem desfilar pelas ruas da cidade com caminhonetes vistosas e mostrar aos "brancos" que não são mais pobres índios.

Gordon (2006), em sua pesquisa com o Xikrin Cateté do Pará, uma comunidade que tem mantido há vários anos contratos comerciais com empresas madeireiras e mineradoras, lembra que eles costumam viajar para outras comunidades só para mostrar que enriqueceram. Gostam que as outras comunidades indígenas vejam quem são os "coitados" agora, fazendo referência a forma com que os Xikrin eram chamados pelos outros índios da região quando tinham pouco dinheiro e não se apresentam com roupas e óculos vistosos.

É assim que, no primeiro momento, os programas desenvolvidos nas comunidades são vistos como a concretização de seus desejos. Dos discursos dos índios pude extrair que as empresas participantes do programa os ajudaram a se tornar mais parecidos com a sociedade envolvente, na medida em que, agora, eles têm eletrodomésticos, veículos e maquinários agrícolas iguais aos dos "brancos", como podemos ver no diálogo que mantive com uma das lideranças de Apucaraninha:

Que nem eu estava te falando que antigamente a gente já sofreu bastante. Só que com o envolvimento da COPEL e mais o Consórcio nós estamos tranquilos agora. [...] Cada programa faz um projetinho pra cada família. Planta milho, feijão. Mas, antigamente, era só trabalhar pra fora, os bóiasfrias que nem eu falei, né. Agora hoje é diferente. Tem uns dias que vem entregar cesta, cesta básica pra nós. Então, hoje nós estamos bem tranquilos agora. Antigamente não tinha carro nenhum, só tinha carro da Funai, agora hoje tem os carros, tem ônibus, tem caminhão. [...] Trator. Três trator e três caminhonete. Cada índio tem o carrinho dele. Hoje mudou bastante. Hoje 
cada índio tem um aparelho de televisão. Antigamente não. Antigamente a gente só dormia na beira do fogo assim e assim amanhecia. Hoje não. Hoje cada casa que você andar você vê geladeira, fogão, sofá... [...] Alguns trabalha... mas a ajuda vem e compra essas coisas, né. (João, kaingang da TI Apucaraninha)

Desde o contato com os "brancos" os índios se interessam pelos objetos que eles traziam. Se antes os espelhos, os martelos e as espingardas eram objetos de desejo, hoje anseiam por veículos e equipamentos de comunicação, produtos que eles viam constantemente no "mundo dos brancos". Mas estes produtos nunca estiveram ao alcance dos índios, por serem bastante custosos. Mas, com o programa, seus desejos de consumo estão sendo realizados.

É fato que os recursos do programa têm permitido uma vida mais confortável aos índios. Nada mais justo, aliás. Afinal, andar até a cidade por estradas empoeiradas sob o sol forte ou enlameadas sob chuva não deve ser agradável. Mas, ao mesmo tempo, os programas têm representado uma maior adesão dos indígenas à ideologia econômica dos "brancos", os colocando em uma situação de dependência, já que não conseguem compreender a lógica utilitarista que subjaz as ações das sociedades capitalistas, deixando um rastro de destruição, como a perda das suas atividades tradicionais, devido a "rápida invasão que vai substituindo antigos valores e práticas por novos mecanismos que representam, de toda forma, um extermínio não necessariamente físico", conforme defende Terena (2000, p. 168).

\subsection{O Índio Capitalista}

As comunidades indígenas ainda hoje são forçadas a se integrar à ideologia da sociedade envolvente, reconstruindo seus valores culturais e modos de vida a fim de criar um ambiente propício ao desenvolvimento. Para Perrot (2008, p. 221):

Deste modo, mesmo que a noção de progresso seja hoje em dia submetida a sérias críticas, o caráter normativo do desenvolvimento como resposta positiva e quase mágica aos problemas que ele mesmo contribuiu para criar continua gravado nas consciências e no imaginário coletivo. 
$\mathrm{Na}$ mentalidade de grande parte dos que atuam nos programas de desenvolvimento das comunidades indígenas, há de se promover uma reconstrução das suas formas de organização social e econômica, dado que suas regras tradicionais desencorajam o desenvolvimento econômico. Sendo assim, propõem a reconstrução do seu modo de vida como único caminho para o que eles denominam como "sucesso".

Por melhor que seja, mais tecnificado que eles forem, é você impor a lógica nossa. E a nossa lógica, por exemplo, o italiano levanta no domingo cedo para ir tratar do porco, se estiver conectado com a cooperativa da Sadia, lá em Toledo. O que cria frango vai tratar do frango $3 / 4 / 5$ vezes por dia, não é? Então, nós ocidentais, eu digo o italiano, os portugueses etc., vamos entrar nessa lógica sabendo que se eu não tratar do frango ele vai morrer... E ele vai perder a renda dele. Aí, eu não sei se eles vão fazer isso, entendeu? Porque eles não trabalham com essa lógica. E os projetos tecnificados, tem que funcionar nos termos certos, senão não dá certo. Então, tem que ir lá e chacoalhar o pé de soja. Quantas lagartas tem? Deu 20 lagartas por metro, você tem que jogar veneno senão ela vai comer sua soja. Não tem conversa. Não tem que ter discussão sobre isso. Não é a lua. Então, quer dizer, você fazer isso com eles, eu acho até um absurdo, mas, se eles quiserem ter retorno, tem que fazer assim. Então impor projetos, se a demanda deles é querer ser igual ao entorno, ele tem que fazer assim. (Carlos, consultor do programa na área de Agronomia)

Os exemplos desse "sucesso" vêm de longe: a partir da década de 1990, as comunidades indígenas dos Estados Unidos são apresentadas como modelos a seguir. Afinal, foram elas que "criaram condições que permitiram a acumulação do capital físico, financeiro e humano" nas comunidades indígenas (TAYLOR, 2008, p. 2) que, assim, "se tornaram finalmente signos do progresso" (CORNELL; KALT, 2007, p. 6, tradução minha).

Alguns dos consultores do Programa de Desenvolvimento da Terra Indígena de Apucaraninha citaram esses "casos de sucesso" como um modelo para as comunidades indígenas brasileiras:

Eu li um texto de um amigo, dos índios Cherokee. Teve uma indenização. Até legal isso. Foi uma ideia que estava toda hora rondando as nossas cabeças na hora de propor a utilização dos recursos do fundo, que é isso foi 
pedido a nós. E eu falei: "olha, tinha essa experiência com os índios Cherokee que compraram... Ganharam uma indenização pela ocupação das terras deles pelos cassinos nos Estados Unidos, acho que região de Las Vegas, não sei. E eles ganharam uma bufunfa de dinheiro. Um valor alto e começaram a investir nos mercados de ações. Compraram outra coisa, uma rede, aquele Rock Café, Café Rock, Hard Rock Café, eles compraram essa rede". Claro que ali eram só 14 milhões. Mas era o seguinte: olha o risco que eles correm e ninguém conseguia entender isso. (Alberto, consultor do programa na área de Administração)

Nos Estados Unidos tem lá. Você vai lá no Arizona eles implantaram um cassino dentro da terra indígena. E eles têm contadores, administradores, economistas, tudo contratado pra gerir o cassino. Eles falam: "nós queremos uma taxa de lucro de tanto por cento do cassino. Se virem". É assim que eles tratam o pessoal. Mesmo lá no Apucaraninha eles podem apresentar um projeto. [...] Ia dar mais empregos, melhorar a vida deles. (Fábio, consultor do programa na área de Antropologia)

Para Alberto e Fábio os problemas dos Kaingang seriam resolvidos com sua adequação à lógica capitalista. Agindo tanto como empresários quanto como investidores no mercado de capitais eles poderiam gerar recursos suficientes para a manutenção das famílias da aldeia, mesmo que esses negócios não tivessem nenhuma relação com seu modo de vida. Segundo Alberto, essa era uma ideia recorrente entre os consultores do programa ("estava toda hora rondando as nossas cabeças"). Talvez porque fosse o caminho mais fácil, do ponto de vista dos "brancos", para reduzir o risco dos índios perderem todo o dinheiro ("olha o risco que eles correm”). Para Fábio, transformar a Terra Indígena em uma empresa - como disse Sílvio (consultor do programa na área de Economia): "gente, olha, isso aqui é uma fazenda" - e os índios em empresários, os destituindo de seus valores socioeconômicos, é natural, visto que o resultado só poderá ser a melhoria da vida deles.

É bom lembrar que a política de atuação com as comunidades indígenas sempre se deu em duas linhas: pela exclusão ou pela assimilação. Pela exclusão, a ordem é segregá-los, os mantendo a distância da sociedade "branca" para que não atrapalhassem o progresso; pela assimilacionista, tentam transformá-los em "brancos", uma vez que seus valores culturais são vistos como negativos. Ambas, no entanto, estão estreitamente relacionadas, sendo a 
assimilação, na realidade, um tipo de exclusão, já que se origina no não reconhecimento da condição de outro, vislumbrando, portanto, o seu desaparecimento, como defende Khaled Junior (2010).

Ao contrário do que pensam Alberto e Fábio, a desconsideração das peculiaridades socioculturais dos indígenas em nome da sua subordinação à lógica capitalista não é garantia de melhoria de suas vidas. Essas intervenções com uma visão empresarial, segundo Perrot (2008, p. 220), acabam por espoliar ainda mais os indígenas, pois tornam "sua existência ainda mais precária". Repete-se o vício histórico em que "o utilitarismo frenético, ligado ao imperativo econômico, revela a cada dia mais do seu caráter irracional e destruidor", avisa Perrot (2008, p. 220).

Como aconteceu com o povo Painter-Suruí em Rondônia que, em 2013, assinou a venda dos créditos de carbono gerados em suas terras para a empresa de cosméticos Natura, o Projeto de Carbono Painter Suruí. Menos de dois anos após, lideranças pedem ao Ministério Público Federal que o projeto seja extinto, alegando que as promessas originais feitas à comunidade de que suas vidas iriam melhorar pois o índio "iria virar empresário", não foram cumpridas (LIDERANÇAS PAINTER-SURUÍ, 2015, p. 1). Devido à perda da autonomia indígena provocada pelo projeto, muitas famílias estavam agora passando fome, pois deixaram de produzir para o consumo próprio devido às limitações de uso da terra impostas pelo acordo, e a comunidade tinha sido dividida devido à forma como estão sendo gerados os recursos.

Alguns poderiam alegar que se trata de um problema pontual devido à má gestão. No entanto, o problema é muito mais complexo. Assegurado pelo poder econômico das grandes empresas, o "indigenismo empresarial", como o define Baines (2000), representa uma grande violência aos povos indígenas. As empresas, agora, tomando o lugar do Estado no papel de tutor das comunidades indígenas, criam um simulacro do índio, como explica Ramos (1995, s/p), "um modelo que acomoda o índio às necessidades da organização”.

As lideranças indígenas são as primeiras a serem cooptadas para se tornarem o índio modelo que as empresas desejam. Como pude perceber entre os kaingang que mantive contato na TI Apucaraninha, as lideranças agem de uma forma mais alinhada à ideia dos "brancos", talvez porque transitem pelo "mundo dos brancos" constantemente. Como ocorre em muitas outras comunidades indígenas pelo Brasil, a emergência do indigenismo empresarial obriga algumas 
lideranças "a estabelecerem certos tipos de relação de subserviência, de cumplicidade e de dependência" com as organizações não-indígenas que representam os programas (LUCIANO, 2006, p. 181).

As lideranças Kaingang, na necessidade de atenderem as demandas da comunidade e para se institucionalizarem no poder, acabaram se unindo à COPEL e enfraqueceram a já precária autonomia indígena, esvaziando o debate político. Marcelo já notou que o programa não precisa efetivamente andar para atender às necessidades das lideranças, visto que momentamente os projetos servem bem aos seus propósitos:

O que a liderança quer e precisa? Eles querem cota de combustível, que pague o conserto da caminhonete, que dê o dinheiro pra fazer a festa, quando eles brigam, guardar a semente quando está faltando... e tudo isso eles conseguem. A o resto não está andando, mas a liderança está se apropriando do programa no que lhe convém, e eles vão fazendo sua política. Então está bom. Eles estão lá gastando uma fortuna de combustível, 15 mil, 17 mil reais por mês em posto de combustível, usando a rodo. Mas no fundo, pra liderança já está ótimo. Eles conseguiram fazer o que eles precisam. E aí eles enxergaram... Eles chegaram ao ponto de olhar e perceber, a gente não precisa efetivamente de um projeto pra acessar o recurso. Eles precisam, aparentemente, a coisa tem que estar ali. Tem que ter o profissional. Tem que ter um projeto porque tem que ter os contratados indígenas, isso daí é distribuição e acesso ao recurso, e a indicação dos funcionários é da liderança. Agora, se está rendendo... Isso não precisa ser visto. Então tá bom. Pra que mexer? [...] Então por mais que tenham a crítica, porque "nossa, a festa custou 30 no primeiro ano e 60 no segundo", eles estão felizes da vida do jeito que está. (Marcelo, sociólogo, facilitador de campo durante o programa)

O combustível, os bens que conseguem comprar e as grandes festas são coisas que eles nunca imaginaram ter. Então, para eles, o programa está funcionando, já que a comunidade enxerga uma época de mais bonança. Poderia estar melhor? Claro que poderia. Mas do jeito que está, na visão das lideranças, ainda é muito melhor do que passaram a vida toda. 
Joana (antropóloga, coordenadora do diagnóstico), lembra que "o que funciona lá para os índios hoje é a questão das festas, onde eles gastam, eles estão liberados para fazer as festas grandes, chamar as pessoas... Então, isso funciona, porque é um coletivo grande, todo mundo festando". Assim, as lideranças se aproveitam bem desses projetos para manter seu poder político, principalmente porque estes são bem aceitos pela comunidade.

As festas são momentos em que as lideranças demonstram seu poder para toda a comunidade, principalmente para as lideranças de outras facções, exibindo os produtos adquiridos com os recursos do programa, como ônibus, tratores e caminhonetes, as bandas de música contratadas que devem ser sempre melhores e mais caras que no ano anterior, e a comida em abundância que é servida a todos.

Como afirma Sousa (2010), as comunidades indígenas também desejam o desenvolvimento econômico. Afinal, elas estão inseridas em um modelo que a geração de riquezas é priorizada. É assim que os Kaingang de Apucaraninha não querem mais produzir alimentos para o consumo próprio, como arroz, feijão, mandioca e milho, preferindo adquiri-los nos supermercados nas cidades de Tamarana e Londrina, conforme levantamento realizado pelos consultores do Programa de Sustentabilida Sócio-Ambiental da Terra Indígena Apucaraninha ([2011a]). Sonham mesmo com as monoculturas extensivas de soja e eucalipto.

É a propaganda. A sociedade envolvente já não produz culturas alimentares básicas. O que se vê pela região são as vastas plantações de monocultura para atender as indústrias locais, como a Klabin, uma grande indústria do setor de papel e celulose, e as cooperativas capitalistas, como a Integrada Cooperativa Agroindustrial que trabalha com a comercialização de grãos. Até mesmo pela TV, tecnologia presente em grande parte das casas (PROGRAMA SÓCIOAMBIENTAL DA TERRA INDÍGENA APUCARANINHA, [2011a]), os índios assistem programas que incentivam este tipo de cultura.

Utilizando argumentos científicos, engenheiros agrônomos são figuras constantes nestes programas de $\mathrm{TV}$, explicando as melhores técnicas e as culturas mais rentáveis, que não inclui, logicamente, as culturas alimentares básicas. E quando inclui, elas são apresentadas 
como "alternativas produtivas" para agricultores familiares, bem distante da vida de luxo dos empresários do agronegócios, tão bem retratada pela mídia ${ }^{87}$. Para Barcellos (2009, p. 158):

\begin{abstract}
A homogeneização dos "sujeitos" pelos meios de comunicação de massa, criando uma coletividade subordinada, tem sido um dos principais empecilhos para as comunidades indígenas que também se veem envolvidas neste jogo de massificação.
\end{abstract}

No diagnóstico feito em Apucaraninha para o Programa de Sustentabilidade, os consultores narram a história de dois irmãos que demostraram o interesse de plantar eucalipto. Um dos irmãos, que já trabalha na Klabin, que trouxe a ideia. E o outro diz que "aprendeu a lidar com mudas de eucalipto por meio de programa de televisão e começou a por em prática" (PROGRAMA SÓCIO-AMBIENTAL DA TERRA INDÍGENA APUCARANINHA, [2011a], p. 60). Nada diferente do que acontece há algum tempo por todo país, como constata Santos e Silveira (2006), aonde a produção agrícola vem acompanhando o circuito de produção capitalista em que mesmo os pequenos produtores são impulsionados a produzir para o "sistema agroindustrial".

As sementes crioulas ${ }^{88}$ não são mais encontradas em Apucaraninha, já que normalmente as sementes para o plantio são doadas aos índios pelos "brancos" (PROGRAMA SÓCIOAMBIENTAL DA TERRA INDÍGENA APUCARANINHA, [2011a]). Além do mais, os índios acreditam que não existe demanda dos "brancos" por este tipo de produto, sendo muito difícil sua comercialização. Apesar disso, na festa do dia do índio em 2015, uma das lideranças trouxe milho crioulo de outra comunidade indígena do Paraná para fazer um dos pratos típicos que foi oferecido a todos durante a festa, conforme informações de João (Kaingang, TI Apucaraninha). Infelizmente hoje, esse tipo de cultura parece estar relacionada somente ao passado nas comunidades indígenas. Para o futuro, só há espaço para a monocultura.

\footnotetext{
${ }^{87}$ A formação do mito do empresário rural, ancorada na ideia de sua superioridade, já que são pessoas de sucesso, ricas e modernas, frente ao caipira, atrasado e pobre, tem eficácia simbólica na produção e/ou transformação dos territórios.

${ }^{88}$ Segundo Trindade (2006), "sementes crioulas são aquelas utilizadas por comunidades tradicionais em suas lavouras, com características peculiares que são a sua uniformidade e sua pureza, por não terem sofrido modificações genéticas como, por exemplo, a transgenia e o melhoramento genético".
} 
O problema é que nem sempre conseguem ter acesso a este desenvolvimento, já que enfrentam dificuldades para lidar com as questões técnicas da gestão. Para Luciano (2006, p. 82), “os processos administrativos, financeiros e burocráticos, além de serem inintelegíveis à racionalidade indígena, confrontam e ferem os valores culturais dos seus povos, como o de solidariedade, generosidade e democracia".

É neste contexto que, para os consultores do programa em Apucarinha, os índios devem ser qualificados, conforme as necessidades e regras do mercado, moldadas, portanto, pelo desempenho e resultados, para melhor gerir os contatos de negócios com os "brancos". Partem da ideia de que o capital humano, principalmente no que tange a educação, "pode afetar a habilidade das populações indígenas para tirar vantagem de certos tipos de oportunidades" (CORNELL, 2006, p. 20, tradução minha). Os não-índios alegam a falta de capacitação dos indígenas, dando ênfase aos conhecimentos técnicos em gestão e das atividades produtivas, ambos desenvolvidos sem levar em consideração as questões étnicas. Prevendo que o conhecimento indígena é insuficiente para sua inserção no mercado, chegam a conclusão que a melhor saída é impor a forma dos "brancos" de trabalhar.

Mão de obra era a minha preocupação, porque eu percebi que lá precisava de duas coisas: aprende a trabalhar do jeito que a gente sabe, goste ou não. É pra consegui a sobrevivência deles. É difícil eles se manterem com a cultura deles porque não tem terra o suficiente, não tem mais bicho, não tem mais peixe, não tem mais de onde eles tirarem, certo? Então, eles têm que se adaptar a nossa cultura e sobreviver dessa adaptação deles, né? É fazer uma adaptação nisso (Sílvio, consultor do programa na área de Economia).

Desta forma, para Sílvio, duas coisas eram necessárias: 1) que os índios abandonem suas especificidades culturais; 2) que eles aprendam a trabalhar como os "brancos". De outra forma, não irão sobreviver, fala de forma taxativa.

$\mathrm{Na}$ hora que a gente começou a tomar pé da situação viu também que era o seguinte: que não era necessário um arranjo de recurso tremendo porque a coisa era muito, muito, muito precária na aldeia. Imagina um índio usando um software de gestão de projeto? É, mas eles poderiam fazê-lo, nós imaginávamos. Mas eles não queriam isso. Então, assim, mas nós queríamos fazer o orçamento de fundo que achávamos que era digno de 14 milhões e 
centenas de projetos, dezenas de projetos, não podia fazer isso manualmente, acompanhar, monitorar, ter que avaliar, então você imagina isso né? Mas, esse era o desafio, então a gente falou: o programa vai ter que estar equipado, é só fazermos coisas mais simples, usando excel, propondo cursos de capacitação em excel mesmo, alguma coisa de access, ou seja, coisas que eram acessíveis, softwares livres, enfim. (Alberto, consultor na área de Administração)

Em um artigo sobre as organizações indígenas, Corrêa e Filardi (2007) defendem a sua profissionalização como forma de fortalecimento institucional. A ideia basilar deste texto é que as organizações indígenas devem se adaptar às exigências do ambiente, da mesma forma que qualquer outra empresa. A partir dessa ideia, identificam oito fragilidades nas organizações estudadas propondo, a cada uma, as formas para que sejam corrigidas. Entre os problemas identificados por Corrêa e Filardi (2007, p. 7), dois deles merecem ser citados aqui: a) falta de competências técnico-administrativas, devido a escassez nos índios de habilidades para lidar com a parte instrumental da gestão, “tais como planejamento, gerenciamento dos processos de trabalho, elaboração de documentos [...], técnicas de arquivamento [...], conceitos básicos de orçamento e gerenciamento financeiro"; b) falta de competências gerenciais, ou seja, de "conhecimentos, habilidades e atitudes gerenciais [...] que [os] possibilitem administrar adequadamente as OI".

Para o "equacionamento" destas "fragilidades", Corrêa e Filardi (2007, p. 7) indicam a capacitação dos índios nas técnicas, conceitos e instrumentos básicos de gerenciamento de organizações, por meio de oficinas ou cursos que sejam construídos de uma forma que haja a transferência de experiências realizadas por outras organizações ou instituições, indígenas ou não. Assim, apesar de apontarem que a capacitação deve estar vinculada à realidade das Organizações Indígenas, que neste caso, como frisam os autores, são administradas exclusivamente por índios, em nenhum momento falam de como isso pode ser feito a partir das especificidades culturais e sociais deste público.

O problema é que este tipo de trabalho consiste em transmitir conhecimentos técnicos desenvolvidos em outro contexto e, assim, modifica as práticas indígenas e sua forma de pensamento, inserindo novos discursos e ideologias. Alegando as "carências" econômicas, culturais e sociais dos índios, tratam de convertê-lo a ideologia capitalista e, assim, ao modelo 
de indivíduo auto-interessado, movido exclusivamente por motivos utilitários, visando a maximização de suas próprias escolhas. Nada mais contraditório, portanto, com a lógica Kaingang. 


\section{REFLEXÕES FINAIS}

Quando surgiu a ideia do Programa de Sustentabilidade Socioambiental e Cultural da Terra Indígena Apucaraninha como condicionante para a movimentação de 80\% dos recursos obtidos pelos Kaingang daquela comunidade para a compensação pela implantação e funcionamento da Usina Hidrelétrica de Apucaraninha, seus idealizadores pensaram em termos de participação e autonomia da comunidade indígena.

Acreditavam que o programa poderia ser desenvolvido com plena participação dos indígenas, apesar das décadas de dominação e exploração a que vem sendo expostos, ignorando o poder das ideologias nesta relação: a ideologia do management que, por ser dominante na sociedade "branca", que detém o discurso hegemônico, se impõe sobre as relações entre "brancos" e índios e, até, entre os próprios índios na comunidade.

A ideologia do management não permite que formas de vida não utilitárias sejam respeitadas, já que trabalha com a homogeneização dos sujeitos, construindo uma visão de mundo baseada nos imperativos do mercado e nos resultados econômicos. Prometendo o sucesso pessoal, impõe os valores dominantes do "mundo empresarial”, ancorados em uma lógica econômica capitalista, como se este fosse o único caminho a seguir.

É desta forma que busquei aqui compreender de que forma o management, enquanto ideologia que se materializa em discurso, atua sobre o Programa de Sustentabilidade Socioambiental e Cultural na Terra Indígena Apucarananinha, Paraná.

Para isso, assumindo uma visão pluralista, mais voltada à complexidade organizacional do que o enclausuramento paradigmático (LEWIS; KELEMEN, 2002), busquei interpretar, sob a perspectiva dos elementos da Análise do Discurso na Linha Francesa, os diferentes discursos que atuam no campo visando dar suporte à ideologia do management. Como ferramentas de informações, utilizei a entrevista semiestruturada e o grupo focal, aplicados aos indígenas e aos participantes "brancos" do programa, a análise documental e bibliográfica e o caderno de campo em que anotei as minhas observações e os acontecimentos que observei durante a coleta dos dados. Foram estes diferentes instrumentos de coleta de dados que me trouxeram 
novas questões, modificando o objetivo da minha pesquisa, quando percebi que o foco que eu estava dando não tinha quase nenhuma importância para o fenômeno.

Assim, o meu primeiro objetivo específico foi resgatar o processo histórico de conformação da Terra Indígena Apucaraninha, uma vez que as relações e as mudanças ocorridas (e que ocorrem) são o resultado das forças históricas que atuaram (e atuam) naquele campo. Três acontecimentos, intrinsecamente imbricados, impactaram na vida dos kaingang desde que tiveram contato com os "brancos": 1) a redução do tamanho de suas terras engendrada, inicialmente, pelo Estado; 2) a entrada dos colonizadores na região norte do Paraná, conhecida até então como um "vasto sertão" (MOTA, 2008), que os expropriou de suas terras e, assim, do seu modo de vida tradicional, além de devastar a natureza implantando as monoculturas do café, da soja e do milho e a pecuária extensiva, os obrigando a manter relação com uma outra natureza; 3) a ação tutelar do Estado que os dominou, tornando-os dependentes do assistencialismo estatal.

Foi possível perceber como esses fatores modificaram a vida dos kaigang, possibilitando internamente a reprodução de formas de vida da sociedade envolvente, como nas lavouras que possuem métodos de plantio e colheita e variedades de plantas que não se diferenciam dos seus vizinhos "brancos". Nos últimos anos até mesmo os arrendamentos, mesmo que ilegais, se tornaram práticas constantes nas terras indígenas no sul do Brasil (TOMMASINO, 1995; VEIGA, 2006; LUCIANO, 2006), inclusive em Apucaraninha, onde os kaingang são seduzidos pelos altos ganhos prometidos pelos fazendeiros da região.

Nenhuma destas mudanças, no entanto, levaram os índios a viver melhor e de forma mais autônoma. Na verdade, o que houve foi um empobrecimento material e cultural das comunidades indígenas. Hoje, entre as lideranças indígenas de Apucaraninha, que por falarem português trafegam com mais facilidade entre os "brancos" e, assim, estão mais inseridos no modo de vida e na ideologia dominante da sociedade envolvente, é bastante comum encontrar os mesmos discursos dos fazendeiros da região. Até mesmo com uma visão utilitarista de que os recursos financeiros os levarão a uma vida mais tranquila, mesmo que isso signifique a destruição dos recursos naturais provocados por usinas hidrelétricas que irão compensá-los monetariamente por isso. 
Neste contexto, meu segundo objetivo específico foi identificar as relações de poder que atuam sobre o programa. Com relação e este objetivo, o resultado mais evidente é que, como em programas anteriores, há assimetria de poder, estando os indígenas do lado mais fraco, uma vez que a companhia de energia estadual, a COPEL, conseguiu cooptar o programa de sustentabilidade para seus objetivos, o principal deles, manter os índios sob controle.

Como, já no início do processo, a empresa foi legitimada como a mais competente no que tange a gestão, conseguiu desenhar um Termo de Referência que privilegiava as questões econômicas em detrimento de qualquer outra, dado que foi em termos empresariais que ele foi construído. Isso enrijeceu o programa tornando os objetivos essencialmente econômicos, mesmo que alguns consultores o enxergassem de outra perspectiva.

Em alguns momentos, como no caso da fábrica de fraldas descrito no capítulo 5, os objetivos dos indígenas, que são lastreados em uma visão comunitária e não utilitarista, não foram entendidos, justamente porque na lógica econômica dos não-índios ela não seria economicamente viável, como também exigia o TR. Em muitos discursos ficou claro também a intolerância com que os "brancos" tratam a forma tradicional de vida dos indígenas que, para eles, é a representação do atraso.

O resultado disso é que tanto as expectativas dos indígenas quanto dos participantes "brancos" não são atendidas, recaindo sobre os primeiros, mais uma vez, a culpa pelo desencontro entre o desejado, o planejado e o executado, uma vez que são vistos como não comprometidos, pouco capacitados e hábeis para lidar com o programa. Assim, ao tentarem assimilá-los à sociedade capitalista, impõem o seu modo de vida, não se diferenciando dos programas do passado, ignorando a participação e, portanto, a fusão de horizontes.

O discurso dos "brancos" é tantas vezes repetido que até os indígenas já se convenceram de que não têm condições de administrar os recursos da indenização e precisam, então, da ajuda da COPEL e do MPF. Este sentimento de proteção, no entanto, leva a submissão, como alerta Lima (2012), como me parece vem ocorrendo em Apucaraninha perante a COPEL. Convencidos de que precisam da companhia para a gestão dos recursos, os kaingang, mesmo que algumas vezes se mostrem descontentes, não questionam a importância da COPEL no programa e sim os valores que receberam. 
O meu terceiro objetivo nesta tese foi identificar, por meio dos discursos, a imagem que os "brancos" participantes do programa têm dos índios, de maneira a perceber a partir de que imagem opera a forma de relacionamento com eles. Como pude perceber, a imagem estereotipada dos indígenas, construído no imaginário social por anos, não permitiu o desenvolvimento de um programa participativo, como teoricamente foi idealizado.

Isso porque os índios são vistos pelos participantes "brancos" do programa como indolentes, atrasados e irracionais, em contraposição aos trabalhadores, portadores do progresso e racionais "brancos". Trata-se, portanto, de um discurso de colonizador que se apresenta como superior frente aos não civilizados índios, como defende Bhabha (1998) quando trata das relações entre colonizado e colonizador, justificando as relações de poder (CABAÇO, 2009).

Por fim, meu último objetivo específico era desvelar os discursos que sustentam a disseminação da ideologia do management entre os participantes do programa. Aqui destaco o discurso do colonizador e o discurso capitalista que justificam o discurso do management no programa de desenvolvimento.

O discurso do colonizador, sustentado na dicotomia entre "brancos" (colonizadores) e índios (colonos), acaba por inferiorizar os índios, os fazendo desejar ser "brancos". Se ser índio é ser visto como diferente e inferior, acredita que ao se tornar um "branco" irá se livrar do preconceito a que está submetido, já que, como qualquer ser humano, necessita ser estimado pela sociedade (HONNETH, 2003).

O desejo de se tornar como os "brancos" aciona o jogo da imitação os fazendo aceitar como válidos os discursos capitalistas, nem que seja parcialmente. Os índios não querem ser vistos como diferentes dos "brancos" no que se refere aos aspectos econômicos, mais fáceis de serem visualizados. Assim, querem se vestir como eles, dirigir os mesmos veículos, comer os mesmos alimentos e nos mesmos restaurante, para serem vistos como gente.

O próprio discurso de liberdade em que se sustenta o discurso capitalista os oferece uma falsa perspectiva para que eles possam se livrar dos anos de opressão a que foram submetidos só por serem índios e viverem de uma forma diferente. Não que os indígenas tenham se tornados capitalistas, mas, neste momento, eles me parecem mais suscetíveis a este discurso, já que, 
pela primeira vez na vida, sabem o que é se sentirem invejados pelos recursos materiais que possuem.

Com estes resultados é possível compreender o contexto em que opera o Programa de Desenvolvimento de Apucaraninha e, assim, concluir sobre como ali atua a ideologia do management. Fica claro que o programa, nas condições apresentadas, não é participativo, devido à história de preconceito, exclusão e dominação dos índios que, mesmo inconscientemente, age sobre os participantes, "brancos" ou índios.

É claro que há momentos de resistência, mas que eles são rapidamente controlados pelos "brancos" que ameaçam acabar com o programa, caso os índios não ajam como o esperado. A participação dos índios, então, está determinada a partir de algumas bases delimitadas pelos "brancos" se constituindo mais uma "dominação controlada": é possível dar-lhes a oportunidade de escolher o local em que será desenvolvido algum projeto, mas a eles já foram dadas as opções do que pode ser escolhido, já que quem sabe o que é melhor para os índios é o "branco". Almeida (2010) chama isso de "representação para inglês ver", uma vez que os índios permanecem domesticados pelos "brancos".

Os próprios índios, ao mesmo tempo em que desejam a autonomia, aceitam a interferência dos "brancos" porque já internalizaram os discursos de que são inferiores. Muitos deles reclamavam do programa, mas sempre se referiam a COPEL como uma parceira que só queria "fazer o bem" para eles. Agora não se vestem mais para a guerra quando vão às reuniões com a empresa. Falam alto, discutem, mas acabam aceitando aquilo que já estava decidido pela empresa.

Os índios, então, estão sendo instrumentalizados pelos "brancos" participantes do programa. Nada mais natural à ideologia do management, que visa, constantemente, "domar" as pessoas nas organizações visando o alcance de resultados econômicos (COSTA; BARROS; SARAIVA, 2014). Por isso a desconsideração do seu modo de vida contrário aos preceitos capitalistas e a disseminação de estereótipos estão sempre presentes.

Mas não são só os índios que estão sendo instrumentalizados. Os próprios consultores e os outros participantes "brancos" do programa, ligados às universidades, ao MPF e à COPEL, acabam por ser enquadradados em estereótipos. É assim que os consultores assumem que 
tomam decisões que vão de encontro aos desejos dos índios porque é isso que se espera de bons gestores: que decidam o "melhor" para a comunidade sem se apegar às emoções, somente em bases utilitaristas. Afinal, eles tinham sido contratados para isso.

Para isso é preciso pensar a terra indígena como se uma fazenda fosse e os indígenas empresários do agronegócio. Afinal, o modelo organizacional da empresa e o pensamento administrativo são as panaceias dos novos tempos, em que a esfera econômica reina hegemônica (CHANLAT, 2006). O problema é que uma terra indígena não é uma empresa e a comunidade indígena não é associação capitalista.

Eu não vi, com exceção de algumas lideranças, a preocupação entre os índios com a geração de lucro e sim com a sobrevivência, o que, para eles, como lembra Luciano (2006), está relacionado a uma vida digna. E mesmo entre as lideranças, não é a visão utilitarista que determina, em última instância, as suas ações. Se querem criar gado, por exemplo, não o concebem fora das suas regras tradicionais faccionalistas.

Entre os "brancos" entrevistados o programa não foi feito para isso. É preciso gerar projetos econômicos que gerem lucro para a comunidade e para serem revertidos para a manutenção do próprio projeto, caso contrário o programa não será sustentável. Eu ouvi de alguns "brancos" que o projeto de gado de corte que foi planejado não dará certo porque os índios vão fazer churrasco todos os dias, conforme notas de campo.

Mas, e se fizerem? O recurso utilizado para a aquisição deste gado não é da comunidade? Por que eles não têm direito de utilizá-lo da forma que consideram necessário? Se esquecem que os próprios índios têm mecanismos internos que os permitem resolver seus conflitos sem precisar da participação dos "brancos". Se querem tratá-los como autônomos, que os permitam decidir suas vidas cotidianas.

Com a mesma indignação tratam as festas promovidas pela comunidade com os recursos do fundo, que é da comunidade. Para muitos "brancos", o dinheiro investido nas festas não passa de desperdício de recursos. Até o prefeito da cidade de Apucaraninha veio lhes dar conselhos para que gastem menos nas festas, mostrando como todo mundo se acha no direito de dar palpites no que fazem os "não civilizados" índios, intromissão considerada deselegante entre "brancos". 
É interessante a forma como agimos perante aqueles que têm formas de vida diferentes da nossa que, a partir do nosso ponto de vista, tratamos como inferiores ou superiores. Quando são vistas como superiores tentamos nos parecer com elas, imitando seus modos, seus valores e racionalidades. Mas, quando são vistas como formas de vida inferiores, o preconceito nos torna intolerantes. Mesmo quando esse preconceito não é aparente, acabamos por desconsiderar o outro, impondo a nossa forma de ver o mundo enquanto desqualificamos visões diferentes.

É isso que acontece nas teorias do desenvolvimento que, desde o seu aparecimento, impõem um modo específico de vida - ocidental, masculino e hétero -, remetendo a uma concepção evolucionista e utilitarista. No entanto, o desenvolvimento é tratado, quase sempre, como um conceito neutro e essencialmente positivo, sendo "um dos discursos mais inclusivos no senso comum e na literatura especializada”, defende Ribeiro (2012, p. 213), como se, em nome dele, povos não tivessem sido exterminados, empobrecidos e retirados do seu modo de vida.

A ideia de desenvolvimento forma a base que justifica a colonização, tanto entre os colonizadores europeus que invadiram o resto do mundo, quanto entre colonos do sul do Brasil que se instalaram em terras alheias dentro do país, provocando mudanças profundas na vida dos povos autóctones. Até hoje os países são classificados como desenvolvidos, em desenvolvimento e subdesenvolvidos com base em seus padrões de consumo e industrialização, deixando claro o caráter evolutivo do conceito (GADOTTI, 2000).

É lógico que há diferenças no conceito de desenvolvimento no tempo - angariando diversos adjetivos como econômico, sustentável, étnico e humano -, mas, em todos, está presente o mesmo aparato ideológico que tornou o próprio termo, desenvolvimento, uma ideologia, como defendem Ribeiro (2012) e Cardoso em entrevista concedida a Freire e Becher (2013).

Assim, o desenvolvimento virou o fetiche dos tempos atuais. Para empresas, países, cidades, comunidades rurais, povos indígenas e pessoas, só há uma saída, e ela se chama desenvolvimento. Um desenvolvimento que está imbricado à ideologia do management, na medida em que reconfigura seus processos prometendo a eficiência no uso dos recursos para obtenção dos resultados e a mudança para uma vida melhor e mais feliz. 
Para se justificar, desqualificam o modo de vida tradicional dos locais, os subordinado e fazendo acreditar que o outsider é o salvador para uma situação que também foram forçados a crer ser aquém do que podem alcançar se se tornarem mais parecidos com os de fora, justamente aqueles que ajudaram a criar seus problemas. "Ou se tornam civilizados ou não vão sobreviver", afirmam constantemente, traçando um paralelo entre civilização e capitalismo. Busca-se eliminar os diferentes, já que no management, o objetivo é a homogeneidade, transformando as pessoas em uma massa unidimensional de dominados que anseiam pelo sucesso prometido, mesmo que o preço a pagar seja a perda da própria vida.

No caso dos indígenas da TI Apucaraninha, que sobreviveram há décadas de expoliação, sendo roubados e dominados pela sociedade envolvente, talvez sejam assimilados de uma vez, tendo em vista que a ideologia do management os alcançou, acelerando o processo de dominação, agora travestido nas ideias de autonomia e auto-determinação dos povos indígenas.

Como em toda tese há de se fazer recortes, resultado das escolhas do pesquisador. Neste caso, deixei de fora algumas questões que ainda perduram na minha cabeça e com as quais pretendo trabalhar nos próximos anos. Uma delas está relacionada a uma questão que surgiu no decorrer da pesquisa e que neste estudo, por um conhecimento superficial evidente, somente fiz uma pequena referência: a de que os índios anseiam pela construção das hidrelétricas no rio Tibagi para que recebam as indenizações. Assim, é necessário compreender quais forçam operam para que os indígenas passem a defender a construção de usinas hidrelétricas no Rio Tibagi.

Também acho importante desvendar como a ideologia do management atua em outros grupos da aldeia com as quais não pude trabalhar, como as mulheres e os indígenas que não estão incluídos entre as lideranças, uma vez que tive pouco contato com eles, fazendo a minha pesquisa predominantemente entre as lideranças, grupo mais assimilado aos costumes da sociedade envolvente. Mas, para isso, é preciso se inserir mais profundamente na comunidade, coisa que não tive condições de fazer, devido restrições de tempo.

A compreensão da atuação da ideologia e dos discursos do managament em outras esferas da comunidade, como no caso da educação, é uma outra linha interessante de estudo. Lembrando que a educação é um dos elementos que mais preocuparam os consultores, tendo eles indicado 
mais investimento na formação técnica/profissional dos indígenas. O problema é que a educação está ligada a ideologia dominante e, como diz Althusser (1983), assegura o conhecimento útil ao sistema. Desta forma, como se dará essa relação daqui para frente?

Fora do contexto indígena, estudos devem ser feitos em programas de desenvolvimento implantados em outras comunidade dando ênfase ao papel da ideologia do management e da assimetria nas relações de poder, deixando de lado a ideia de que o desenvolvimento é sempre positivo e que as mudanças em seu nome impetradas vão gerar mudanças que irão melhorar a vida das pessoas.

Por fim, é interessante acompanhar o desenrolar desta história entre os kaingang, já que a capacidade de resistência dos índios pode sempre nos surpreender (ou não) e nos propiciar estudos surpreendentes na área de Estudos Organizacionais. 


\section{REFERÊNCIAS}

ADAMOVSKI, Ezequiel. "Clase media": reflexiones sobre los (malos) usos académicos de una categoria. Nueva Sociedad, n.247, p. p. 38-49, Sep. /Oct. 2013.

ADORNO, Theodor W.; HORKHEIMER, Max. Conceito de iluminismo. In: ARANTES, Paulo Eduardo. (Org.). Theodor W. Adorno: textos escolhidos. São Paulo: Nova Cultural, 1999.

AKTOUF, Omar. Ensino de administração: por uma pedagogia para a mudança. Organizações \& Sociedade, v.12, n.35, p. 151-159, Out./Dez. 2005.

ALBERT, Bruce. Associações indígenas e desenvolvimento sustentável na Amazônia brasileira. In: RICARDO, Carlos Alberto (Beto). (Edit.). Povos indígenas no Brasil: 1996/2000. São Paulo: Instituto Socioambiental, 2000.

ALMEIDA, Antonio Cavalcante. Organização Kaingang: o caso das lideranças tradicionais e políticas no Paraná. Revista Ciências Sociais em Perspectiva, v.13, n.25, 2. semestre 2014. Sem paginação.

ALMEIDA, Eduardo. Autonomia indígena em laboratório. In: RICARDO, Beto; RICARDO, Fany. (Edit.). Povos indígenas no Brasil: 2001/2005. São Paulo: Instituto Socioambiental, 2006.

ALMEIDA, Fábio Vaz Ribeiro de. O índio sabe, o índio faz: os dilemas da participação indígena nas políticas públicas. In: SOUSA, Cássio Noronha Inglez de; ALMEIDA, Fábio Vaz Ribeiro de; LIMA, Antonio Carlos de Souza; MATOS, Maria Helena Ortolan. (Org.). Povos indígenas: projetos e desenvolvimento II. Rio de Janeiro: Laced, 2010.

ALTHUSSER, Louis. Aparelhos Ideológicos de Estado: nota sobre os aparelhos Ideológicos de Estado (AIE). Rio de Janeiro: Edições Graal, 1983.

ALVESSON, Mats; DEETZ, Stanley. Teoria crítica e abordagens pós-modernas para estudos organizacionais. In: CKEGG, Stewart R.; HARDY, Cynthia; NORD, Walter R. (Org.). Handbook de Estudos Organizacionais: modelos de análise e novas questões em estudos organizacionais. São Paulo: Atlas, 2006.

AMBONI, Nerio; CARMINHA, Daniel Ouriques. Abordagem Multiparadigmática em Estudos Organizacionais: indo muito mais além da visão hegemônica. In: COLÓQUIO INTERNACIONAL DE EPISTEMOLOGIA E SOCIOLOGIA DA CIÊNCIA DA ADMINISTRAÇÃO, 4., Florianópolis, 2014. Anais Eletrônicos..., 2014.

AMOSSY, Ruth. O ethos na intersecção das disciplinas: retórica, pragmática, sociologia dos campos. In: AMOSSY, Ruth. (Org.). Imagens de si no discurso: a construção do ethos. São Paulo: Contexto, 2005.

ANEEL - AGÊNCIA NACIONAL DE ENERGIA ELÉTRICA. Resolução nº. 652, de 09 de Dezembro de 2003. Brasília, 2003. Disponível em: $<$ http://www.aneel.gov.br/cedoc/res2003652.pdf>. Acesso em: 27 Abr. 2015. 
ARAÚJO, Ana Valéria. Direitos indígenas no Brasil: breve relato de sua evolução histórica. In: ARAÚJO, Ana Valéria (Org.). Povos indígenas e as leis dos "brancos": o direito à diferença. Brasília: Ministério da Educação, Secretaria de Educação Continuada, Alfabetização e Diversidade; LACED/Museu Nacional, 2006.

ARRUDA, Rinaldo Sérgio Vieira. Imagens do índio: signos de tolerância. In: GRUPIONI, Luís Donizete Benzi; VIDAL, Lux; FISCHMANN, Roseli. Povos indígenas e tolerância: construindo práticas de respeito e solidariedade. (Org.). São Paulo: Editora da Universidade de São Paulo, 2001.

AZANHA, Gilberto. Fim do garimpo e da madeira: até quando? In: RICARDO, Beto; RICARDO, Fany. (Edit.). Povos indígenas no Brasil: 2006/2010. São Paulo: Instituto Socioambiental, 2011.

BAINES, Stephen G. Terras indígenas e projetos de mineração e usinas hidrelétricas na Amazônia: alternativas de desenvolvimento ou novas formas de dominação. In: ENCONTRO ANUAL DA ANPOCS, 38., Caxambu, 2014. Anais Eletrônicos..., 2014.

BAINES, Stephen G. Imagens de liderança indígena e o Programa Waimiri-Atroari: índios e usinas hidrelétricas na Amazônia. Revista de Antropologia, São Paulo, USP, v. 43, n.2, p. 141-163, 2000.

BAINES, Stephen G. A política indigenista governamental e os Waimiri-Atroari: administrações indigenistas, mineração de estanho e a construção da "autodeterminação indígena” dirigida. Revista de Antropologia, São Paulo, USP, v.36, p. 207-237, 1994.

BAINES, Stephen G. O território dos Waimiri-Atroari e o indigenismo empresarial. Ciencias Sociais Hoje, p.219-243, 1993.

BAKHTIN, Mikhail. Marxismo e filosofia da linguagem. 3. ed. São Paulo: Hucitec, 1986.

BARCELLOS, Gilsa Helena. Território e territorialidades tupiniquim. Revista em Pauta, v.6, n.24, p. 139-163, Dez. 2009.

BARROS, Amon; CARRIERI, Alexandre de Pádua. O cotidiano e a história: construindo novos olhares na Administração. RAE - Revista de Administração de Empresas, São Paulo, v.55, n.2, p. 151-161, Mar./abr. 2015.

BAUMAN, Zygmunt. Modernidade e ambivalência. Rio de Janeiro: Jorge Zahar Ed., 1999.

BELLUZZO, Luiz Gonzaga de Mello. Ensaios sobre o capitalismo do século XX. São Paulo: Editora UNESP: Campinas: UNICAMP, Instituto de Economia, 2004.

BENDASSOLLI, Pedro F. Prefácio: o mal-estar na sociedade de gestão e a tentativa de gestão do mal-estar. In: GAULEJAC, Vincent de. Gestão como doença social: ideologia, poder gerencialista e fragmentação social. Aparecida: Ideias \& Letras, 2007. (Coleção Management, 4).

BENDASSOLLI, Pedro Fernando. Público, privado e o indivíduo no novo capitalismo. Tempo Social - Revista de Sociol. USP, São Paulo, v.12, n.2, p. 203-236, Nov. 2000. 
BERGAMO, Mônica. Não existe mais latifúndio no Brasil, diz nova ministra da agricultura. Folha de São Paulo, 05 Jan. 2015. Disponível em: $<$ http://www1.folha.uol.com.br/poder/2015/01/1570557-nao-existe-mais-latifundio-no-brasildiz-nova-ministra-da-agricultura.shtml>. Acesso em: 06 Abr. 2015.

BERMANN, Célio. Os projetos das mega-obras hidrelétricas na Amazônia: sociedade e ambiente frente à ação governamental. In: ZHOURI, Andréa. (Org.). Desenvolvimento, reconhecimento de direitos e conflitos territoriais. Brasília: ABA, 2012.

BHABHA, Homi K. O local da cultura. Belo Horizonte: Editora UFMG, 1998.

BICALHO, Renata de Almeida; PAULA, Ana Paula Paes de. Empresa Júnior e a reprodução da ideologia da Administração. Cadernos Ebape.br, Rio de Janeiro, v.10, n.4, artigo 7, p. 894-910, Dez. 2012.

BOLTANSKI, Luc; CHIAPELLO, Éve. O novo espírito do capitalismo. São Paulo: Editora WMF Martins Fontes, 2009.

BOURDIEU, Pierre. O poder simbólico. 7. ed. Rio de Janeiro: Bertrand Brasil, 2004a.

BOURDIEU, Pierre. Coisas ditas. São Paulo: Brasiliense, 2004b.

BRANDÃO, Helena H. Nagamine. Introdução à análise do discurso. 2. ed. rev. Campinas: Editora da UNICAMP, 2004.

BRANDÃO, Helena Hathsue Nagamine. Análise do discurso: um itinerário histórico. In: PEREIRA, Helena Bonito Couto; ATIK, Maria Luiza Guarnieri. (Org.). Língua, literatura e cultura em diálogo. São Paulo: Ed. Mackenzie, 2003.

BRAVERMAN, Harry. Trabalho e capital monopolista: a degradação do trabalho no século XX. 3. ed. Rio de Janeiro: Zahar, 1977.

BURREL, Gibson. Ciência normal, paradigmas, metáforas, discursos e genealogia da análise. In: CKEGG, Stewart R.; HARDY, Cynthia; NORD, Walter R. (Org.). Handbook de Estudos Organizacionais: modelos de análise e novas questões em estudos organizacionais. São Paulo: Atlas, 2006.

BURREL, Gibson; MORGAN, Gareth. Sociological paradigms and organisational analysis. Burlington: Ashgate, 2005.

CABAÇO, José Luís. Moçambique: identidade, colonialismo e libertação. Sâo Paulo, Editora UNESP, 2009.

CAMPBELL, Colin. Eu compro, logo sei que existo: as bases metafísicas do consumo moderno. In: BARBOSA, Lívia; CAMPBELL, Colin. (Org.). Cultura, consumo e identidade. Rio de Janeiro: Editora FGV, 2006.

CARRIERI, Alexandre de Pádua. As gestões e a sociedade. Farol - Revista de Estudos Organizacionais e Sociedade, Belo Horizonte, n. 1, p. 19-57, Jun. 2014.

CARVALHO, José Luis Felício; CARVALHO, Frederico Antonio A.; BEZERRA, Carol. O monge, o executivo e o estudante ludibriado: uma análise empírica sobre leitura eficaz entre 
alunos de administração. Cadernos Ebape.br, Rio de Janeiro, v.8, n.3, artigo 9, p. 535-549, Set. 2010 .

CASTRO, Eduardo Viveiros de. No Brasil, todo mundo é índio, exceto quem não é. In: RICARDO, Beto; RICARDO, Fany. (Edit.). Povos indígenas no Brasil: 2001/2005. São Paulo: Instituto Socioambiental, 2006.

CAVAZZA, Nicoletta. Psicologia das atitudes e das opiniões. São Paulo: Loyola, 2008.

CHANLAT, Jean-François. Ciências Sociais e Management. Revista de Administração da FEAD-Minas, v.3, n.2, p. 9-17, Dez. 2006.

CHIARA, Márcia de. $80 \%$ dos brasileiros não controlam suas finanças. O Estado de São Paulo, 27 Jan. 2014. Disponível em: <http://economia.estadao.com.br/noticias/geral,80-dosbrasileiros-nao-controlam-suas-financas, 176437e >. Acesso em: 20 Ago. 2015.

CIMINO, James. Moradores de Higienópolis se mobilizam contra estação de metrô. Folha de São Paulo, 13 Ago. 2010. Disponível em: $<$ http://www1.folha.uol.com.br/fsp/cotidian/ff1308201011.htm>. Acesso em: 15 Ago. 2015.

CIMBALUK, Lucas. Indenização a uma comunidade indígena: projetos de sustentabilidade e tutela. In: ENCONTRO ANUAL DA ANPOCS, 38., Caxambu, 2014. Anais Eletrônicos..., 2014.

CIMBALUK, Lucas. A criação da aldeia Água Branca na Terra Indígena Kaingang Apucaraninha: "política interna", moralidade e cultura. Dissertação (Mestrado em antropologia Social) - Departamento de Antropologia - Universidade Federal do Paraná, Curitiba, 2013.

COHN, Clarice. Culturas em transformação: os índios e a civilização. São Paulo em Perspectiva, v.15, n.2, 2001.

COPEL. Usina Apucaraninha. 21 Jan. 2014. Disponível em: $<$ http://www.copel.com/hpcopel/root/nivel2.jsp?endereco=\%2Fhpcopel\%2Froot $\% 2$ Fpagcopel 2.nsf\%2F044b34faa7cc1143032570bd0059aa29\%2F90abd1ca771741e603257412004eb700>. Acesso em: 08 Abr. 2015.

COPEL. Copel e índios de Apucaraninha selam acordo sobre usina inaugurada em 1949. Agências de Notícias - Estado do Paraná, 01 Dez. 2006. Disponível em: http://www.historico.aen.pr.gov.br/modules/noticias/article.php?storyid=24775>. Acesso em 04 Out. 2015.

COPEL. Relatório Ambiental: termo de compromisso Copel-IAP. 1999. Disponível em: $<$ http://www.copel.com/hpcopel/root/pagcopel2.nsf/arquivos/relambientalapc/\$FILE/Rel AmbientalAPC.pdf>. Acesso em: 08 Abr. 2015.

CORNELL, Stephen. Indigenous peoples, poverty and self-determination in Australia, New Zealand, Canada and the United States. Tucson: Native Nations Institute for Leadership, Management, and Policy; Cambridge: Harvard Project on American Indian Economic Development, 2006. (Joint Occasional Papers on Native Affairs). 
CORNELL, Stephen; KALT, Joseph. Two approaches to development of native nations: one works, the other doesn't. In: JORGENSEN, Miriam. (Edit.). Rebuilding native nations: strategies for governance and development. Tucson: The University of Arizona Press, 2007.

CORRÊA, Vera Lúcia de Almeida; FILARDI, Fernando. Fortalecimento institucional de Organizações Indígenas. In: ENANPAD - ENCONTRO DA ASSOCIAÇÃO NACIONAL DE PÓS- GRADUAÇÃO E PESQUISA EM ADMINISTRAÇÃO, 31., Rio de Janeiro, 2007. Anais Eletrônicos..., 2007.

COSTA, Alessandra de Sá Mello da; BARROS, Denise Franca; MARTINS, Paulo Emílio Matos. A alavanca que move o mundo: o discurso da mídia de negócios sobre o capitalismo empreendedor. Cadernos Ebape.br, Rio de Janeiro, v.10, n.2, artigo 6, p. 357-375, Jun. 2012.

COSTA, Alessandra de Sá Mello da; BARROS, Denise Franca; SARAIVA, Luiz Alex. Management Industry. Cadernos Ebape.br, Rio de Janeiro, v.12, n.1, apresentação, p. 1-6, Jan./Mar. 2014.

COSTA, Everaldo Batista; SUZUKI, Júlio César. A ideologia espacial constitutiva do Estado nacional brasileiro. Scipta Nova, Barcelona, v.16, n.418 (6), Nov. 2012.

DEMO, Pedro. Metodologia científica em ciências sociais. 3. ed. rev. e ampl. São Paulo: Atlas, 1995.

DESLAURIERS, Jean-Pierre; KÉRISIT, Michèle. O delineamento da pesquisa qualitativa. In: POUPART, Jean; DESLAURIERS, Jean-Pierre; GROULX, Lionel-H.; LAPERRIÈRE, Ane; MAYER, Robert; PIRES, Álvaro P. (Org.). A pesquisa qualitativa: enfoques epistemológicos e metodológicos. Petrópolis: Vozes, 2010.

DÍAZ-POLANCO, Héctor. Elogio de la diversidad: globalización, multiculturalismo y etnofagia. Mexico: Siglo XXI, 2006.

DONADONE, Julio Cesar. Imprensa de negócios, dinâmica social e os gurus gerenciais. ENEO - ENCONTRO NACIONAL DE ESTUDOS ORGANIZACIONAIS, 1., Curitiba, 2000. Anais Eletrônicos..., 2000.

EAGLETON, Terry. Ideologia. São Paulo: Editora UNESP: Boitempo, 1997.

ESCOBAR, Arturo. Encountering development: the making and unmaking of the third world. New Jersey: Princeton University Press, 1995.

FANON, Frantz. Pele negra, máscaras brancas. Salvador: EDUFBA, 2008.

FARIA, José Henrique de; MENEGHETTI, Francis Kanashiro. Razão tradicional e razão crítica: os percursos da razão no ensino e pesquisa em Administração na concepção da Teoria Crítica. In: ENANPAD - ENCONTRO DA ASSOCIAÇÃO NACIONAL DE PÓSGRADUAÇÃO E PESQUISA EM ADMINISTRAÇÃO, 29., Brasília, 2005. Anais Eletrônicos..., 2005.

FARIA, José Henrique de; MENEGHETTI, Francis Kanashiro. As organizações e a sociedade unidimensional: as contribuições de Marcuse. In: ENEO - ENCONTRO DE ESTUDOS ORGANIZACIONAIS, 2., Recife, 2002. Anais Eletrônicos..., 2002. 
FAVARO, Thomaz. Capital dos bilionários. Veja, ed. 2072, 6 ago. 2008. Disponível em: $<$ http://veja.abril.com.br/060808/p_162.shtml>. Acesso em: 28 Jul. 2014.

FEITOSA, Saulo Ferreira. A política indigenista na agenda neoliberal. In: RICARDO, Beto; RICARDO, Fany. (Edit.). Povos indígenas no Brasil: 2001/2005. São Paulo: Instituto Socioambiental, 2006.

FERGUSON, James. The anti-politics machine. In: SHARMA, Aradhana; GUPTA, Akhil. (Edit.). The anthropology of the state: a reader. Malden: Blackwell Publishing, 2006.

FERNANDES, Ricardo Cid. Kaingang resistem e lutam pela terra. In: RICARDO, Carlos Alberto (Beto). (Edit.). Povos indígenas no Brasil: 1996/2000. São Paulo: Instituto Socioambiental, 2000.

FERREIRA, Fabio Vizeu. Management no Brasil em perspectiva histórica: o projeto do IDORT nas décadas de 1930 e 1940. Tese (Doutorado em Administração) - Programa de Doutorado em Administração de Empresas - Fundação Getúlio Vargas, São Paulo, 2008.

FEYERABEND, Paul. Contra o método. Rio de Janeiro: Francisco Alves, 1977.

FIOCRUZ - FUNDAÇÃO OSVALDO CRUZ; FASE. Mapa de Conflitos Envolvendo Injustiça Ambiental e Saúde no Brasil. 2009. Disponível em: $<$ http://www.conflitoambiental.icict.fiocruz.br/index.php?pag=ficha\&cod=169>. Acesso em 08 Abr. 2015.

FOUREZ, Gérard. A construção das ciências: introdução à filosofia e à ética das ciências. São Paulo: Editora da Universidade Estadual Paulista, 1995.

FREIRE, José Ribamar Bessa. Cinco idéias equivocadas sobre os índios. Paletra proferida no dia 22 de abril de 2002 no curso de extensão de gestores dos municípios do Rio de Janeiro. Rio de Janeiro, 2002.

FREIRE, Silene de Moraes; BECHER, Mariela Nathalia. A ideologia persistente do desenvolvimento: entrevista com Miriam Limoeiro Cardoso. Revista em Pauta - Revista da Faculdade de Serviço Social da Universidade do Estado do Rio de Janeiro, v.11, n.31, 1. Semestre de 2013.

FUCS, José. Os russos agora querem luxo. Época, Especial Rússia, 18 nov. 2911. Disponível em: $\quad<\underline{\text { http://revistaepoca.globo.com/tempo/noticia/2011/11/os-russos-agora-querem- }}$

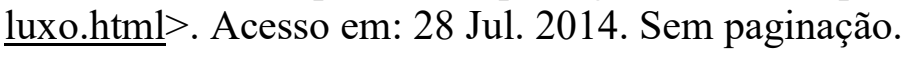

GADOTTI, Moacir. Pedagogia da terra. 5. ed. São Paulo: Peirópolis, 2000.

GALLOIS, Dominique Tilkin. Cultura "indígena” e sustentabilidade: alguns desafios. Tellus, Campo Grande, ano 5, n.8/9, p. 29-36, Abr./Out. 2005.

GALLOIS, Dominique Tilkin. Terras ocupadas? Territórios? Territorialidades? In: RICARDO, Fany. (Org.). Terras indígenas \& unidades de conservação da natureza: o desafio das sobreposições territoriais. São Paulo: Instituto Socioambiental, 2004.

GALLOIS, Dominique Tilkin. "Nossas falas duras": discurso político e auto-representação Waiãpi. In: ALBERTO, Bruce; RAMOS, Alcinda Rita. (Org.). Pacificando o branco: 
cosmologias do contato no Norte-Amazônico. São Paulo: Editora UNESP; Imprensa Oficial do Estado, 2002.

GATTI, Lucianno. Theodor W. Adorno: indústria cultural e crítica da cultura. In: NOBRE, Marcos. (Org.). Curso livre de Teoria Crítica. 2. ed. Campinas: Papirus, 2008.

GAULEJAC, Vincent de. Gestão como doença social: ideologia, poder gerencialista e fragmentação social. Aparecida: Ideias \& Letras, 2007. (Coleção Management, 4).

GAULEJAC, Vincent de. Crítica dos fundamentos da ideologia de gestão. In: CHANLAT, Jean-François; FACHIN, Roberto; FISCHER, Tânia. (Org.). Análises das organizações: perspectivas latinas. Porto Alegre: Editora da UFRGS, 2006. V.1: olhar histórico e constatações atuais.

GIOIA, Dennis; PITRE, Evelyn. Multiparadigm perspectives on theory building. Academy of Management Review, v.15, n.4, p. 584-602, Oct. 1990.

GODOY, Arilda Schmidt. Pesquisa qualitativa: tipos fundamentais. RAE - Revista de Administração de Empresas, São Paulo, v.35, n.3, p. 20-29, Maio/Jun. 1995.

GÓES, Paulo Roberto Homem de. Relatório Anual de Atividades: Projeto Básico Ambiental: componente indígena: UHE Mauá. Jul. 2014. Disponível em: < http://www.usinamaua.com.br/upload/tiny_mce/Relatorio_Anual_de_Atividades_-_PBA-CI__15-07-2014.pdf>. Acesso em: 02 Out. 2015.

GONÇALVES, Carlos Walter Porto. Os (des)caminhos do meio ambiente. 14. ed. São Paulo: Contexto, 2006.

GONÇALVES, Carlos Walter Porto. Da geografia às geo-grafias: um mundo em busca de novas territorialidades. In: SADER, Emir. (Coord.). La guerra infinita: hegemonía y terror mundial. Buenos Aires: CLACSO, 2002.

GONDIM, Sônia Maria Guedes. Grupos focais como técnica de investigação qualitativa: desafios metodológicos. Paidéia, v.12, n.24, p. 149-161, 2003.

GORDON, César. Economia selvagem: ritual e mercadoria entre os índios XikrinMebêngôkre. São Paulo: Editora Unesp: ISA; Rio de Janeiro: NuTI, 2006.

GORZ, André. Metamorfoses do trabalho: crítica da razão econômica. 2. ed. São Paulo: Annablume, 2007.

GORZ, André. O imaterial: conhecimento, valor e capital. São Paulo: Annablume, 2005.

GOULART, Ana Caroline. "Quando a aldeia é na cidade": uma análise sobre a translocalidade de um acampamento Kaingang na Praça Ângelo Kretã na cidade de Londrina. Trabalho de Conclusão de Curso (Graduação em Ciências Sociais) -Universidade Estadual de Londrina, Londrina, 2011.

GREGOLIN, Maria do Rosário. Formação discursiva, redes de memória e trajetos sociais de sentido: mídia e produção de identidades. Discursividade, n.2, Dez. 2008. Sem paginação. 
GRYNSZPAN, Mário. Ciência, política e trajetórias sociais: uma sociologia histórica da teoria das elites. Rio de Janeiro: Ed. Fundação Getúlio Vargas, 1999.

GRÜN, Mauro. Descartes, historicidade e educação ambiental. In: CARVALHO, Isabel Cristina Moura de; GRÜN, Mauro; TRAJBER, Rachel. (Org.). Pensar o ambiente: bases filosóficas para a educação ambiental. Brasília: Ministério da Educação, Secretaria de Educação Continuada, Alfabetização e Diversidade, UNESCO, 2006.

GRUPIONI, Luis Donisete Benzi. Imagens contraditórias e fragmentadas: sobre o lugar dos índios nos livros didáticos. R. Bras. Est. Pedag., Brasília, v.77, n.186, p. 409-437, Maio/Ago. 1996.

GRUPO DE PESQUISA ORGANIZAÇÃO E PRÁXIS LIBERTADORA. Organização e práxis libertadora. Farol - Revista de Estudos Organizacionais e Sociedade, Belo Horizonte, n.1, p. 252-319, Jun. 2014.

GUATTARI, Felix; ROLNIK, Suely. Micropolítica: cartografias do desejo. 4. ed. Petrópolis: Vozes, 1996.

HARVEY, David. A produção capitalista do espaço. São Paulo: Annablume, 2005.

HASSARD, John; KELEMEN, Mihaela. Production e consumption in organizational knowledge: the case of the 'paradigms debate'. Organization, v.9, n.2, p. 331-355, May 2002 .

HASSARD, John; KELEMEN, Mihaela; WOLFRAM-COX, Julie. Disorganization Theory: explorations in alternative organizational analysis. New York: Routledge, 2008.

HELM, Cecilia Maria Vieira. A UHE Mauá no Rio Tibagi (Paraná): impactos socioambientais e o desafio da participalão indígena. In: VERDUM, Ricardo. (Org.). Integração, usinas hidrelétricas e impactos socioambientais. Brasília: INESC, 2007.

HERMAN, Edward S.; CHOMSKY, Noam. Manufacturing consent: the political economy of the mass media. New York: Phanteon Books, 2002.

HICKS, Stephen R. C. Educando para o empreendedorismo. 02 ago. 2014. Disponível em: $<$ http://www.stephenhicks.org/2014/08/02/educando-para-o-empreendedorismo/>. Acesso em 03 ago. 2014. Sem paginação.

HISSA, Cássio Eduardo Viana. Território de diálogos possíveis. In: RIBEIRO, Maria Tereza Franco; MILANI, Carlos Roberto Sanchez. Compreendendo a complexidade socioespacial contemporânea: o território como categoria de diálogo interdisciplinar. Salvador: UDUFBA, 2009.

HOBART, Mark. Introduction: the growth of ignorance. In: HOBART, Mark. (Edit.). An anthropological critique of development: the growth of ignorance. New York: Routledge, 2002.

HONNETH, Axel. Luta por reconhecimento: a gramática moral dos conflitos sociais. São Paulo: Ed. 34, 2003.

HOOKS, Bell. Black Looks: race and representation. Boston: South End Press, 1992. 
HUENEMANN, Charlie. Racionalismo. Petrópolis: Vozes, 2012.

IBGE - INSTITUTO BRASILEIRO DE GEOGRAFIA E ESTATÍSTICA. Paraná: Tamarana: Infográficos: dados gerais do município. 2014. Disponível em: < http://www.cidades.ibge.gov.br/painel/painel.php?lang=\&codmun=412667\&search=parana\% 7Ctamarana\%7Cinfograficos:-dados-gerais-do-municipio>. Acesso em: 23 Ago. 2015.

ITUASSU, Cristiana Trindade; TONELLI, Maria José. Sucesso, mídia de negócios e a cultura do management no Brasil. Cadernos Ebape.br, Rio de Janeiro, v.12, n.1, artigo 5, p. 86-111, Jan./Mar. 2014.

JORGENSEN, Miriam. Editor's introduction. In: JORGENSEN, Miriam. (Edit.). Rebuilding native nations: strategies for governance and development. Tucson: The University of Arizona Press, 2007.

KEHL, Maria Rita. Fetichismo. In: BUCCI, Eugênio; KEHL, Maria Rita. Videologias: ensaios sobre televisão. São Paulo: Boitempo, 2004. Coleção Estado de Sítio.

KHALED JUNIOR, Salah H. Horizontes identitários: a construção da narrativa nacional brasileira pela historiografia do século XIX. Porto Alegre: EDIPUCRS, 2010.

KOPELKE, André Luiz; BOEIRA, Sérgio Luís. Estudos organizacionais críticos e o Ensino de Graduação em Administração no Brasil. In: ENEO - ESTUDOS DE ESTUDOS ORGANIZACIONAIS DA ANPAD, 8., Gramado, 2014. Anais Eletrônicos..., 2014.

JUNIOR ACHIEVEMENT. Institucional. [s/d]. Disponível em: $<$ http://www.juniorachievement.org.br/jabr/junior-achievement/institucional $>$. Acesso em 2 ago. 2014.

LACAN, Jacques. O seminário: livro 5: as formações do inconsciente. Rio de Janeiro: Jorge Zahar, 1999.

LAFEUILLE, Philippe. O movimento EJ. In: MATOS, Franco de. (Org.). A empresa júnior no Brasil e no mundo. São Paulo: Martin Claret, 1997.

LATOUR, Bruno. Ciência em ação: como seguir cientistas e engenheiros sociedade afora. São Paulo: Editora UNESP, 2000.

LAUFER, Romain. Mudança social e o ensino de gestão: entre ciência, técnica e prática. In: CHANLAT, Jean-François; FACHIN, Roberto; FISCHER, Tânia. (Org.). Análises das organizações: perspectivas latinas. Porto Alegre: Editora da UFRGS, 2006. V.1: olhar histórico e constatações atuais.

LAZAGNA, Angela. Lenin, as forças produtivas e o taylorismo. Dissertação (Mestrado em Sociologia) - Programa de Pós-Graduação em Sociologia - Universidade Estadual de Campinas, Campinas, 2002.

LEÃO, Silvana. Povo Kaingang: indenização ajuda a resgatar tradições. Folha de Londrina, 31 Mar. 2013. Disponível em: $<$ http://www.uel.br/com/agenciaueldenoticias/index.php?arq=ARQ_not\&FWS_Ano_Edicao= $1 \&$ FWS_N_Edicao $=1 \&$ FWS_Cod_Categoria $=2 \& F W S \_$N_Texto $=16573>$. Acesso em: 25 Out. $201 \overline{5}$. 
LEE, Sang M.; CHANG, Daesung; LIM, Seong-Bae. Impact of entrepreneurship education: a comparative study of the U.S. and Korea. International Entrepreneurship and Management Journal, v.1, p. 27-43, 2005.

LERNER, Daniel. The passing of tradicional society. New York: Free Press, 1958.

LEWIS, Marianne W.; GRIMES, Andrew J. Metatriangulação: construção teórica com base em paradigmas múltiplos. In: CALDAS, Miguel P. ; BERTERO, Carlos Osmar. (Coord.). Teoria das Organizações. São Paulo: Atlas, 2007.

LIDERANÇAS PAINTER-SURUÍ. Nota de esclarecimento. 2015. Disponível em: $<$ http://cimi.org.br/pub/Economia\%20Verde/Nota\%20de\%20Esclarecimento\%20Suru.pdf $>$. Acesso em: 06 Set. 2015.

LIMA, Antonio Carlos de Souza. Povos indígenas no Brasil contemporâneo: de tutelados a “organizados"? In: SOUSA, Cássio Noronha Inglez de; ALMEIDA, Fábio Vaz Ribeiro de; LIMA, Antonio Carlos de Souza; MATOS, Maria Helena Ortolan. (Org.). Povos Indígenas: projetos e desenvolvimento II. Brasília: Paralelo 15; Rio de Janeiro: LACED, 2010.

LIMA, Ludmila Moreira. Diálogo intercultural e participação indígena no PPTAL. Revista Anthropológicas, ano 8, v.15, n.2, p. 85-106, 2004.

LIMBERTI, Rita de Cássia Pacheco. A imagem do índio: discursos e representações. Dourados: Ed. UFGD, 2012.

LITTLE, Paul E. Gestão territorial em terras indígenas: definição de conceitos e proposta de diretrizes: relatório final. Rio Branco: SEMA/SEPI/GTZ, 2006. Disponível em: $<$ http://www.kaninde.org.br/upload/2012/04/gestao_territorial_em_terras_indagenas_133384 1653_1334544840.pdf>. Acesso em: 28 Abr. 2015.

LITTLE, Paul E. Etnodesenvolvimento local: autonomia cultural na era do neoliberalismo global. Tellus, Campo Grande, ano 2, n.3, p. 33-52, Out. 2002.

LOPES, Mariana Carvalho; LOPES, Paulo da Costa; LIMA, Zuleica Amaral Alves de Lima. A Contribuição da empresa júnior de administração no Brasil. Revista ANGRAD, v. 8, n. 1, p. 33-52, 2007.

LUCIANO, Gersem dos Santos. O índio brasileiro: o que você precisa saber sobre os povos indígenas no Brasil de hoje. Brasília: Ministério da Educação, Secretaria de Educação Continuada, Alfabetização e Diversidade; LACED/Museu Nacional, 2006.

LUNA, Denise. Eike começou vendendo apólices de seguros. Exame, 10 mar. 2010. Disponível em: <http://exame.abril.com.br/negocios/noticias/eike-comecou-carreiravendendo-apolices-seguros-539481>. Acesso em: 31 Jul. 2014.

LUZ, France; OMURA, Ivani Aparecida Rogatti. A propriedade rural no sistema de colonização da Companhia Melhoramentos Norte do Paraná: município de Maringá. In: ANPUH - SIMPÓSIO NACIONAL DOS PROFESSORES UNIVERSITÁRIOS DE HISTÓRIA, 8., Aracaju, 1975. Anais..., 1975.

MARCUSE, Herbert. A ideologia da sociedade industrial: o homem unidimensional. 4. ed. Rio de Janeiro: Zahar Editores, 1973. 
MARTTILA, Tomas. The culture of enterprise in neoliberalism: specters os entrepreneurship. New York: Routledge, 2013.

MARX, Karl. O 18 de brumário de Luís Bonaparte. São Paulo: Boitempo, 2011.

MATOS, Maria Helena Ortolan. Execução e gestão de projetos indígenas: criando tradição e/ou reflexão? In: SOUSA, Cássio Noronha Inglez de; LIMA, Antonio Carlos de Souza; ALMEIDA, Fábio Vaz Ribeiro de; WENTZEL, Sondra. (Org.). Povos indígenas: projetos e desenvolvimento. Rio de Janeiro: Contra Capa Livraria, 2007.

MATSUKI, Edgar. Administração é o curso superior com mais estudantes no país. UOL Educação, 172013.2 set. 20 Disponível $<$ http://educacao.uol.com.br/noticias/2013/09/17/censo-administracao-e-o-curso-com-maisestudantes-do-pais.htm $>$. Acesso em: 01 ago. 2014.

MATTOS, Pedro Lincoln C. L. de. O que diria Popper à literatura administrativa de mercado? RAE - Revista de Administração de Empresas, v.43, n.1, p. 60-69, Jan./Fev./Mar. 2003.

MAZZA, Carmelo; ALVARES, José Luis. Haute Couture and Prêt-à-Porter: the popular press and the diffusion of management practice. Organization Studies, v.21, n.567, May 2000.

MEMMI, Albert. Retrato do colonizado precedido pelo retrato do colonizador. 2. ed. Rio de Janeiro: Paz e Terra, 1977.

MENDONÇA, André Luis de Oliveira; VIDEIRA, Antonio Augusto Passos. Progresso científico e incomensurabilidade em Thomas Kuhn. Scientiae Studia, São Paulo, v.5, n.2, p. 169-183, 2007.

MENEGHETTI, Francis Kanashiro. Liberdade ou autonomia: reflexões críticas sobre as organizações. In: ENANPAD - ENCONTRO DA ASSOCIAÇÃO NACIONAL DE PÓSGRADUAÇÃO E PESQUISA EM ADMINISTRAÇÃO, 31., Rio de Janeiro, 2007. Anais Eletrônicos..., 2007.

MIGLIOLI, Jorge. O colapso soviético e os movimentos socialistas. Cadernos AEL, v.1, n.2, p. 49-62, 1995.

MISOCZKY, Maria Ceci de Araújo; VECCHIO, Rafael Augusto. Experimentando pensar: da fábula de Barnard à aventura de outras possibilidades de organizar. Cadernos Ebape.br, v.4, n.1, Mar. 2006.

MOREAU, Filipe Eduardo. Os índios nas cartas de Nóbrega e Anchieta. São Paulo: Annablume, 2003.

MOTA, Lúcio Tadeu. A presença indígena no vale do Rio Tibagi/PR no início do século XX. Antíteses, v.7, n.13, p. 358-391, Jan./Jun. 2014.

MOTA, Lúcio Tadeu. A guerra dos índios Kaingang: a história épica dos índios Kaingang no Paraná (1769-1924). 2. ed. Revista e ampliada. Maringá: Eduem, 2008.

MOTA, Lúcio Tadeu. Os índios Kaingang e seus territórios nos campos do Brasil meridional na metade do século XIX. In: MOTA, Lúcio Tadeu; NOELLI, Francisco Silva; 
TOMMASINO, Kimiye. (Org.). Uri e Wãxí: estudos interdisciplinares dos Kaingang. Londrina: Ed. UEL, 2000.

MOURA, Guilherme Lima. Hipergeneralizações: organizações são quase qualquer coisa em bestsellers de introdução à Administração. Cadernos Ebape.br, Rio de Janeiro, v.2, n.1, artigo 4, p. 62-85, Jan./Mar. 2014.

MOZDZENSKI, Leonardo. A minha voz alheia: algumas reflexões basilares sobre as ideias do Círculo de Bakhtin. Revista EntreLetras, n.1, 2010.

MPF - MINISTÉRIO PÚBLICO FEDERAL. PROCURADORIA DA REPÚBLICA NO MUNICÍPIO DE LONDRINA. Termo Aditivo ao Ajustamento de Conduta celebrado em $1^{\circ}$ de dezembro de 2006: Inquérito Civil Público $n^{\circ}$ 1.25.005.000832/2006-55. Londrina, 11 Jan. 2010. Sem paginação.

MPF - MINISTÉRIO PÚBLICO FEDERAL. PROCURADORIA DA REPÚBLICA NO MUNICÍPIO DE LONDRINA. Termo de Ajustamento de Conduta: Inquérito Civil Público $n^{\circ}$ 02/01. Londrina, 01 Dez. 2006.

MPF - MINISTÉRIO PÚBLICO FEDERAL. Nota técnica no . 6: parecer/2005. 29 Jun. 2005. Disponível em: < http://6ccr.pgr.mpf.mp. br/atuacao-do-mpf/extrajudicial/recomendacaodocs/empreendimentos/recomendacao_prm_londrina_01_2005.pdf $>$. Acesso em: 27 Abr. 2015. Sem paginação.

NAÇÕES UNIDAS. Declaração das Nações Unidas sobre os Direitos dos Povos Indígenas. Rio de Janeiro: UNIC-Rio, 2008.

NÖTZOLD, Ana Lúcia Vulfe; BRINGMANN, Sandor Fernando. O Serviço de Proteção aos Índios e os projetos de desenvolvimento dos Postos Indígenas: o Programa Pecuário e a Campanha do Trigo entre os Kaingang da IR7. Revista Brasileira de História \& Ciências Sociais, v.5, n.10, p. 147-166, Dez. 2013.

NOVAK, Éder da Silva.Territórios e grupos indígenas no Paraná: a expropriação de terras através do acordo de 1949. In: ENCONTRO REGIONAL DE HISTÓRIA, 14., Campo Mourão, 2014. Anais Eletrônicos..., 2014.

NOVAK, Éder da Silva. Tekoha e Emã: a luta das populações indígenas por seus territórios e a política indigenista no Paraná da Primeira República - 1889 a 1930. Dissertação (Mestrado em História) - Program de Pós-Graduação em História - Universidade Estadual de Maringá, Maringá, 2006.

OLIVEIRA, Roberto Cardoso de. O trabalho do antropólogo. 2. ed. Brasília: Paralelo 15; São Paulo: Editora Unesp, 2006.

OLIVEIRA, Roberto Cardoso de. Sobre o diálogo intolerante. In: GRUPIONI, Luís Donizete Benzi; VIDAL, Lux; FISCHMANN, Roseli. (Org.). Povos indígenas e tolerância: construindo práticas de respeito e solidariedade. São Paulo: Editora da Universidade de São Paulo, 2001.

OLIVEIRA FILHO, João Pacheco de. Cidadania e globalização: povos indígenas e agências multilaterais. Horizontes Antropológicos, Porto Alegre, ano 6, n.14, p. 125-141, Nov. 2000. 
ORLANDI, Eni Puccinelli. Análise do discurso: princípios e procedimentos. Campinas: Pontes, 1999.

ORLANDI, Eni Puccinelli. Discurso, imaginário social e conhecimento. Em Aberto, Brasília, ano 14, n.61, p. 53-59, Jan./Mar. 1994.

OUTHWAITE, William; BOTTOMORE, Tom. Dicionário do pensamento social do século XX. Riode Janeiro: Jorge Zahar, 1996.

PAGLIARO, Heloisa; AZEVEDO, Marta Maria; SANTOS, Ricardo Ventura. Demografia dos povos indígenas no Brasil: um panorama crítico. In: PAGLIARO, Heloisa; AZEVEDO, Marta Maria; SANTOS, Ricardo Ventura. (Org.). Demografia dos povos indígenas no Brasil. Rio de Janeiro: Editora Fiocruz e Associação Brasileira de Estudos Populacionais/Abep, 2005.

PAULA, Ana Paula Paes de. Para além dos paradigmas nos Estudos Organizacionais: o Círculo das Matrizes Epistêmicas. Cadernos Ebape.br, Rio de Janeiro, v.14, n.1, artigo 2, p. 24-46, Jan./Mar. 2016.

PAUlA, Ana Paula Paes de; WOOD JR., Thomaz. Pop-management. Revista Ciência Empresarial, Curitiba, n.2, p. 17-34, 2002.

PÊCHEUX, Michel. O discurso: estrutura ou acontecimento. 2. ed. Campinas: Pontes, 1997.

PELIZZOLI, Marcelo Luiz. O Eu e a diferença: Husserl e Heidegger. Porto Algre: EDIPUCRS, 2002.

PERROT, Dominique. Quem impede o desenvolvimento circular? (desenvolvimento e povos autóctones: paradoxos e alternativas). Cadernos de Campo, São Paulo, n.17, p. 219-232, 2008.

PESOVENTO, Adriane. Os índios e a educação no mundo colonial: fronteira oeste da América portuguesa. Revista Eletrônica de Educação, v.9, n.1, p. 9-26, 2015.

POLANYI, Karl. A grande transformação: as origens de nossa época. 2.ed. Rio de Janeiro: Campus, 2000.

PORTAL KAINGANG. Áreas Kaingang. [20--]. Disponível em:

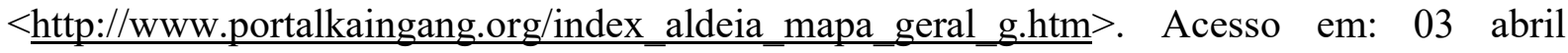
2015.

POUPART, Jean. A entrevista do tipo qualitativo: considerações epistemológicas, teóricas e metodológicas. In: POUPART, Jean; DESLAURIERS, Jean-Pierre; GROULX, Lionel-H.; LAPERRIĖRE, Ane; MAYER, Robert; PIRES, Álvaro P. (Org.). A pesquisa qualitativa: enfoques epistemológicos e metodológicos. Petrópolis: Vozes, 2010.

PRESTES MOTTA, Fernando Cláudio. As empresas e a transmissão da ideologia. RAE Revista de Administração de Empresas, São Paulo, v.32, n.5, p. 38-47, Nov./Dez. 1992.

PRESTES MOTTA, Fernando Cláudio. Controle social nas organizações. RAE - Revista de Administração de Empresas, Rio de Janeiro, v.19, n.3, p. 11-25, Jul./Set. 1979. 
PRESTES MOTTA, Fernando Cláudio; VASCONCELOS, Isabella F. Gouveia. Teoria Geral da Administração. São Paulo: Thomson Learning, 2006.

PROGRAMA DE SUSTENTABILIDADE SÓCIO-AMBIENTAL DA TERRA INDÍGENA APUCARANINHA. Produto 9. Tamarana, [2011a]. v.1.

PROGRAMA DE SUSTENTABILIDADE SÓCIO-AMBIENTAL DA TERRA INDÍGENA APUCARANINHA. Produto 9. Tamarana, [2011b]. v.2.

RAMOS, Alcida Rita. O índio hiper-real. Revista Brasileira de Ciências Sociais, São Paulo, v.10, n.28, Jun. 1995. Sem paginação.

REIS, José. Estado e mercado: uma perspectiva institucionalista e relacional. Revista Crítica de Ciências Sociais, v.95, p. 11-34, Dez. 2011.

REZENDE, Gervásio Castro de. Programa de Crédito Especial para Reforma Agrária (PROCERA): institucionalidade, subsídio e eficácia. Rio de Janeiro: IPEA, 1999. Texto para discussão n.648.

RIBEIRO, Darcy. O povo brasileiro: a formação e o sentido do Brasil. 2. ed. São Paulo: Companhia das Letras, 1995.

RIBEIRO, Gustavo Lins. Poder, redes e ideologia no campo do desenvolvimento. In: ZHOURI, Andréa. (Org.). Desenvolvimento, reconhecimento de direitos e conflitos territoriais. Brasília: ABA, 2012.

RODRIGUES, Marcio Silva; DELLAGNELO, Eloise Helena Livramento. Do discurso e de sua análise: reflexões sobre os limites e possibilidades na Ciência da Administração. Cadernos Ebape.br, Rio de Janeiro, v.11, n.4, artigo 8, p. 621-635, Dez. 2013.

ROMÃO, Lucília Maria Sousa. Memória e ideologia: a propósito do discurso jornalístico. Veredas on Line, Juiz de Fora, v.1, p. 145-159, 2007.

ROMEIRO, Ademar Ribeiro. Desenvolvimento sustentável: uma perspectiva econômicoecológica. Estudos Avançados, v.26, n;74, 2012.

RÜCKERT, Aldomar Arnaldo. O processo de reforma do Estado e a Política Nacional de Ordenamento Territorial. In: OFICINA SOBRE A POLÍTICA NACIONAL DE ORDENAMENTO TERRITORIAL, 1., Brasília, 2003. Anais..., 2005.

SAID, Edward W. Orientalismo. 2. ed. Barcelona: Debolsillo, 2008

SALVIANI, Roberto. As propostas para participação dos povos indígenas no Brasil em Projetos de Desenvolvimento geridos pelo Banco Mundial: um ensaio de análise crítica. Dissertação (Mestrado em Antropologia Social) - Museu Nacional - Universidade Federal do Rio de Janeiro, Rio de Janeiro, 2002.

SANT'ANA, Ruth Bernardes de. A implicação do pesquisador na pesquisa interacionista na escola. Psicologia em Revista, Belo Horizonte, v.16, n.2, p. 370-387, Ago. 2010.

SANTOS, Luzia Aparecida Oliva dos. O percurso da indianidade na literatura brasileira: matizes da figuração. São Paulo: Editora UNESP; Cultura Acadêmica, 2009. 
SANTOS, Milton. Economia espacial: críticas e alternativas. 2. ed. São Paulo: Editora da Universidade de São Paulo, 2003.

SAQUET, Marcos Aurélio; CANDIOTTO, Luciano Zanetti Pessôa; ALVES, Adilson Francelino. Construindo uma concepção reticular e histórica para estudos territoriais. In: PEREIRA, Sílvia Regina; COSTA, Benhur Pinós da; SOUZA, Edson Belo Clemente de. (Org.). Teorias e práticas territoriais: análise espaço-temporais. São Paulo: Expressão Popular, 2010.

SARAIVA, Luiz Alex Silva. Um farol nos Estudos Organizacionais brasileiros. [Editorial]. Farol - Revista de Estudos Organizacionais e Sociedade, Belo Horizonte, n.1, p. 1-16, Jun. 2014.

SARAIVA, Luiz Alex Silva. A educação superior em administração no Brasil e a questão da emancipação: um túnel no fim da luz? Revista Unifacs, v.12, n.1, 2011.

SARAIVA, Luiz Alex Silva; IRIGARAY, Hélio Arthur dos Reis. Políticas de diversidade nas organizações: uma questão de discurso? RAE - Revista de Administração de Empresas, São Paulo, v.49, n.3, p. 337-348, Jul. /Set. 2009.

SCHÖN, Donald A. The reflective practitioner: how professionals think in action. United States of America: Basic Books, 1983.

SCHRÖDER, Peter. Economia indígena: situação atual e problemas relacionados a projetos indígenas de comercialização na Amazônia Legal. Recife: Editora Universitária UFPE, 2003.

SESC-SP. Descobri que era índio quando fui pra escola. 27 Ago. 2014. Disponível em: $<$ http://www.sescsp.

org.br/online/artigo/compartilhar/7899_DESCOBRI+QUE+ERA+INDIO+QUANDO+FUI+P RA+ESCOLA>. Acesso em: 07 Out. 2015.

SEIXAS, Jacy Alves de. Formas da arrogância e história: citações contemporâneas. In: HAROCHE, Claudine; LOPES, Myrian Bahia; DÉLOYE, Yves. (Org.). Ensaios sobre a arrogância. Belo Horizonte: NEHCIT/EA UFMG, 2015.

SHENHAV, Yehouda. Manufacturing racionality: the engineering foundation of the managerial revolution. New York: Oxford University Press, 2002.

SILVA, Franklin Leopoldo e. Conhecimento e razão instrumental. Psicologia USP, São Paulo, v.8, n.1, p. 11-31, 1997.

SILVA, Tomaz Tadeu da. A reprodução social da identidade e da diferença. In: SILVA, Tomaz Tadeu da (Org.). Identidade e diferença: a perspectiva dos estudos culturais. Petrópolis: Vozes, 2000.

SILVA, Anielson Barbosa da; ROMAN NETO, João. Perspectiva multiparadigmática nos estudos organizacionais. In: GODOI, Christiane Kleinübing; BANDEIRA-DE-MELLO, Rodrigo; SILVA, Anielson Barbosa da. (Org.). Pesquisa qualitativa em estudos organizacionais: paradigmas, estratégias e métodos. São Paulo: Saraiva, 2006.

SIMMEL, GEORG. Filosofia del dinero. Madrid: Instituto de Estúdios Políticos, 1977. 
SMITH, Adam. A riqueza das nações: investigação sobre sua natureza e suas causas. São Paulo: Nova Cultural, 1996. V.1.

SOUSA, Cássio Noronha Inglez de. Perspectiva indígena sobre projetos, desenvolvimento e povos indígenas: entrevista com Valéria Paye Pereira Kaxuyana e Euclides Pereira Macuxi. In: SOUSA, Cássio Noronha Inglez de; ALMEIDA, Fábio Vaz Ribeiro de; LIMA, Antonio Carlos de Souza; MATOS, Maria Helena Ortolan. (Org.). Povos Indígenas: projetos e desenvolvimento II. Brasília: Paralelo 15; Rio de Janeiro: LACED, 2010.

SOUZA, Mariana Mayumi Pereira de; CARRIERI, Alexandre de Pádua. A análise do discurso em Estudos Organizacionais. In: SOUZA, Eloisio Moulin de. (Org.). Metodologias e analíticas qualitativas em pesquisa organizacional: uma abordagem teórico-conceitual. Vitória: EDUFES, 2014.

SOUZA, Roberta Bandeira de. Liberdade, propriedade e trabalho em Locke e Hegel. Argumentos, ano 4, n.7, p. 119-130, 2012.

SOUZA, Vânia Rocha Fialho e. Desenvolvimento e associativismo indígena no nordeste brasileiro: mobilizações e negociações na configuração de uma sociedade plural. Tese (Doutorado em Sociologia) - Programa de Pós-Graduação em Sociologia - Universidade Federal de Pernambuco, 2003.

STADEN, Hans. Viagem ao Brasil. Rio de Janeiro: Officina Industrial Graphica, 1930.

STAVENHAGEN, Rodolfo. Etnodesenvolvimento: uma dimensão ignorada no pensamento desenvolvimentista. Anuário Antropológico, p. 11-44, 1984.

STONE, Linda. Cultural crossroads of community participation in development: a case from Nepal. Human Organization, v.48, n.3, p. 206-213, 1989.

SUÁREZ, Águeda Gómes. El discurso político indígena en América Latina. Desacatos, n.24, p. 215-228, Mayo/Ago. 2007.

TAYLOR, Jonathan B. Determinants of development sucess in the native nations of the United States. Tucson: Native Nations Institute for Leadership, Management, and Policy; Cambridge: Harvard Project on American Indian Economic Development, 2008.

TELLES, Edward E. Race in another america: the significance of skin color in Brazil. New Jersey: Princeton University Press, 2004.

TERENA, Marcos. O futuro das populações indígenas na sociedade brasileira. In: RATTNER, Henrique. (Org.). Brasil no limiar do século XXI: alternativas para a construção de uma sociedade sustentável. São Paulo: Editora da Universidade de São Paulo, 2000. (Coleção Estante USP - Brasil 500 anos)

TOMAZI, Nelson Dacio. "Norte do Paraná": história e fantasmagoria. Tese (Doutorado em História) - Departamento de História - Universidade Federal do Paraná, 1997.

TOMMASINO, Kimiye. Os povos indígenas no Paraná: 500 anos de encobrimento. 01 Mar. 2011. Disponível em: <http://ktommasino.blogspot.com.br/2011/03/os-povos-indigenas-noparana-500-anos.html> . Acesso em 03 Abr. 2015. 
TOMMASINO, Kimiye. Territórios e territorialidade Kaingang: resistência cultural e historicidade de um grupo Jê. In: MOTA, Lúcio Tadeu; NOELLI, Francisco Silva; TOMMASINO, Kimiye. (Org.). Uri e Wãxí: estudos interdisciplinares dos Kaingang. Londrina: Ed. UEL, 2000.

TOMMASINO, Kimiye. A história dos Kaingáng da bacia do Tibagi: uma sociedade Jê meridional em movimento. Tese (Doutorado em Antropologia) - Faculdade de Filosofia, Letras e Ciências Humanas - Universidade de São Paulo, São Paulo,1995.

TRAgtenberg, Maurício. A Revolução Russa. 2. ed. rev. São Paulo: Editora UNESP, 2007.

TRAGTENBERG, Maurício. Administração, poder e ideologia. 3. ed. rev. São Paulo: Editora UNESP, 2005.

TRINDADE, Carina Carreira. Sementes crioulas e transgênicos, uma reflexão sobre sua relação com as comunidades tradicionais. In: ENCONTRO NACIONAL DO CONPEDI CONSELHO NACIONAL DE PESQUISA E PÓS-GRADUAÇÃO EM DIREITO, 15. Manaus, 2006. Anais Eletrônicos..., 2006.

VAINER, Carlos B. Planejamento territorial e projeto nacional: os desafios da fragmentação. Revista Brasileira de Estudos Urbanos e Regionais, v.9, n.1, p. 9-23, Maio 2007.

VAINER, Carlos B. Pátria, empresa e mercadoria: notas sobre a estratégia discursiva do Planejamento Estratégico Urbano. In: ARANTES, Otília; VAINER, Carlos; MARICATO, Ermínia. (Org.). A cidade do pensamento único: desmanchando consensos. 3. ed. Petrópolis: Vozes, 2000.

VALLA, Victor Vincent. Sobre participação popular: uma questão de perspectiva. Cad. Saúde Pública, Rio de Janeiro, v.14, Sup. 2, p. 7-18, 1998.

VEIGA, Juracilda. Arrendamento e privatização da terra indígena. In: RICARDO, Beto; RICARDO, Fany. (Edit.). Povos indígenas no Brasil: 2001/2005. São Paulo: Instituto Socioambiental, 2006.

VENOSA, Roberto. Organização e a panacéia participativa ou participação e a panacéia organizacional. RAC- Revista de Administração Pública, Rio de Janeiro, v.8, n.4, p. 80102, Out./Dez. 1974.

VIZEU, Fabio; MENEGHETTI, Francis Kanashiro; SIEFERT, Rene Eugenio. Por uma crítica ao conceito de sustentabilidade nos estudos organizacionais. In: EnEO - ENCONTRO DE ESTUDOS ORGANIZACIONAIS DA ANPAD, 7., Curitiba, 2012. Anais Eletrônicos..., 2012.

WOOD JR., Thomaz. PAULA, Ana Paula Paes de. Pop-management literature: popular business press and management culture in Brazil. Canadian Journal of Administrative Sciences, v.25, n.3, p. 185-200, 2008.

WRIGHT, Ronald. Uma breve história do progresso. Rio de Janeiro: Record, 2007.

WOOD JR., Thomaz. PAULA, Ana Paula Paes de. Mídia especializada e a cultura do management. Organizações \& Sociedade, v.13, n.38, p. 91-105, Jul./Set. 2006. 
ZUINI, Priscila. 7 exemplos de crianças empreendedoras. Exame, 23 Maio de 2012. Disponível em: $\quad<$ http://exame.abril.com.br/pme/noticias/7-exemplos-de-criancasempreendedoras $>$. Acesso em: 31 Jul. 2014. Sem paginação. 


\section{APÊNDICES}

\section{APÊNDICE A - ROTEIRO SEMIESTRUTURADO DE ENTREVISTA (INDÍGENAS)}

\section{Bloco 1 - O(a) entrevistado(a)}

Naturalidade. Família. Escolaridade. Idade. Habitação. Trajetória pessoal. Trajetória profissional. Entrada na TI, caso não seja nativo. Trajetória na TI. Relação com a TI e seu povo.

\section{Bloco 2 - A Terra Indígena de Apucaraninha}

História. Organização da TI. Perfil da população. Cultura local. O que é ser indígena (kaingang). O contexto social, econômico e político hoje. Relação entre as aldeias. Relação da TI com as cidades vizinhas.

\section{Bloco 3 - A usina hidrelétrica de Apucaraninha}

História. Significados. Impactos. Resistências e lutas. Visão sobre a COPEL. Visões sobre o MPF.

\section{Bloco 4 - A Indenização}

Como o valor foi dividido na TI (quem definiu?). Utilização do valor recebido. Impactos positivos (O que trouxe de bom para a TI e para a vida do entrevistado). Impactos negativos. A TI depois do TAC (pontos fortes e fracos, mudanças sociais e econômicas).

\section{Bloco 5 - O Projeto de Sustentabilidade}

Importância e expectativas. Significados. Sobre a entrada dos consultores na TI (colaboração, conflitos). Desenvolvimento dos projetos. Implantação dos projetos. A TI depois do projeto de sustentabilidade (pontos fortes e fracos, mudanças sociais e econômicas). Comparação com outras realidades. 


\section{APENDICE B - ROTEIRO SEMIESTRUTURADO DE ENTREVISTA (DEMAIS ENTREVISTADOS)}

\section{Bloco 1 - O(a) entrevistado(a)}

Idade. Escolaridade. Trajetória profissional. Relação com a TI e seu povo.

\section{Bloco 2 - A Terra Indígena de Apucaraninha}

Visão sobre os indígenas. Cultura local. Infraestrutura. Meios de produção. Relação com os vizinhos. Conhecimento sobre a usina hidrelétrica de Apucaraninha e as lutas para a indenização.

\section{Bloco 3 - O Projeto de Sustentabilidade}

História. Objetivos do Programa. Participação pessoal. Motivação para participação. Treinamentos obtidos sobre o objeto. Visitas à TI. Participação dos consultores, COPEL, MPF e indígenas. Resultados alcançados. Avaliação (erros e acertos). Obstáculos enfrentados. Relação com o desenvolvimento da TI.

\section{Bloco 4 - O futuro}

Futuro da TI. Condições de vida da população indígena. Importância do projeto de sustentabilidade para a TI. Principais mudanças previstas. Visão do seu papel no futuro da TI. Comparação com outras realidades. 